\title{
DETAILED STUDY OF SELENIUM AND SELECTED ELEMENTS IN WATER, BOTTOM SEDIMENT, AND BIOTA ASSOCIATED WITH IRRIGATION DRAINAGE IN THE MIDDLE GREEN RIVER BASIN, UTAH, 1988-90
}

By Doyle W. Stephens, U.S. Geological Survey Bruce Waddell, U.S. Fish and Wildlife Service Lorri A. Peltz, U.S. Geological Survey

Jerry B. Miller, U.S. Bureau of Reclamation

U.S. GEOLOGICAL SURVEY

Water-Resources Investigations Report 92-4084

U.S. GEOLOGICAL SURVEY

U.S. FISH AND WILDLIFE SERVICE

U.S. BUREAU OF RECLAMATION

U.S. BUREAU OF INDIAN AFFAIRS

Salt Lake City, Utah 1992

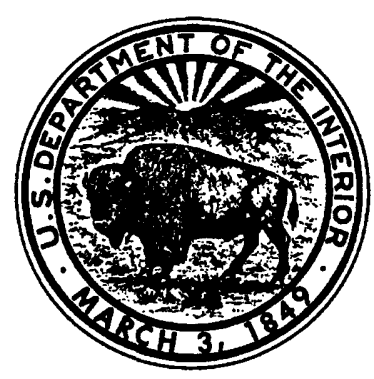




\title{
U.S. DEPARTMENT OF THE INTERIOR
}

\author{
MANUEL LUJAN, JR., Secretary
}

U.S. GEOLOGICAL SURVEY

Dallas L. Peck, Director

For additional information write to:

District Chief

U.S. Geological Survey, WRD

Room 1016 Administration Building

1745 West 1700 South

Salt Lake City, Utah 84104
Copies of this report can be purchased from:

\author{
U.S. Geological Survey \\ Books and Open-File Reports Section \\ Federal Center \\ Box 25425 \\ Denver, Colorado 80225
}




\section{CONTENTS}

Abstract

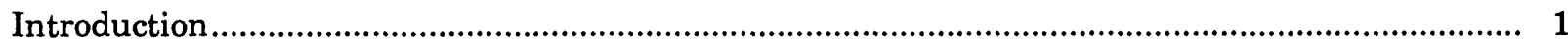

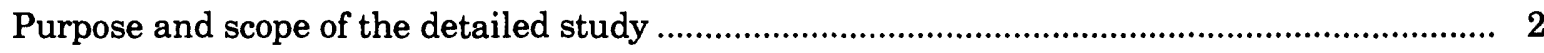

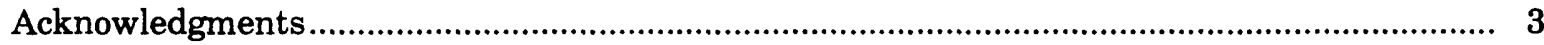

Location and wildlife use of the middle Green River basin ............................................ 5

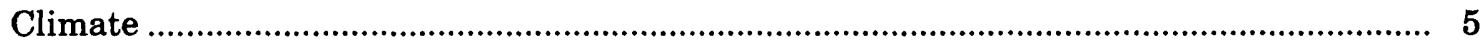

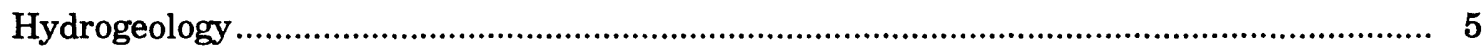

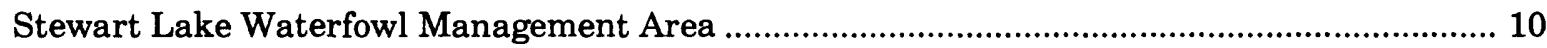

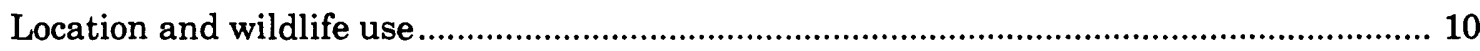

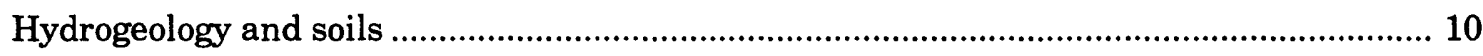

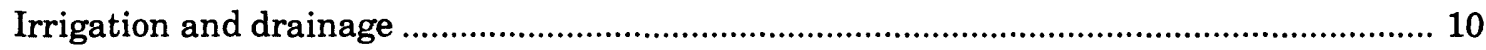

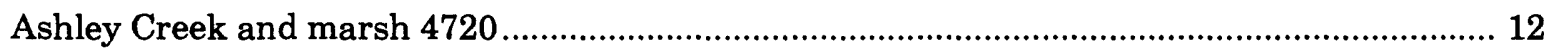

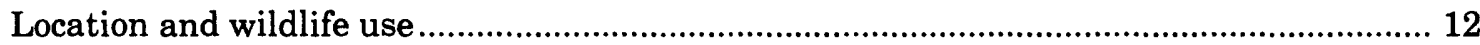

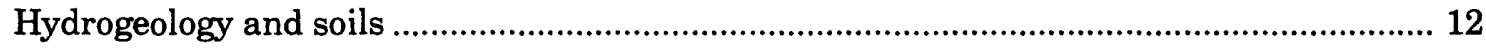

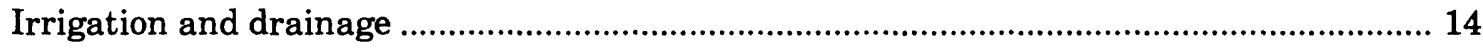

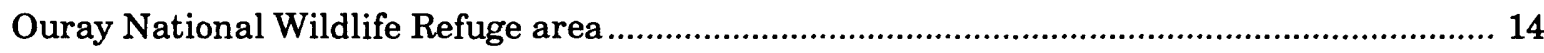

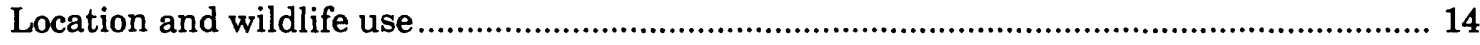

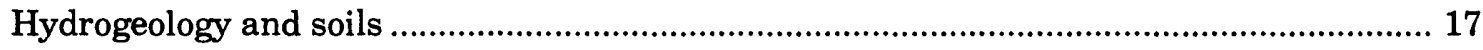

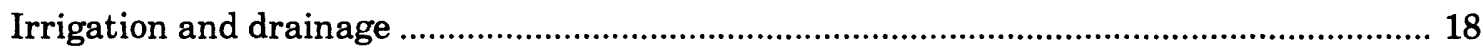

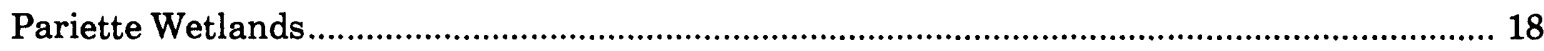

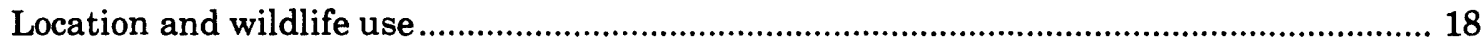

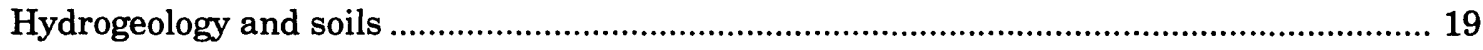

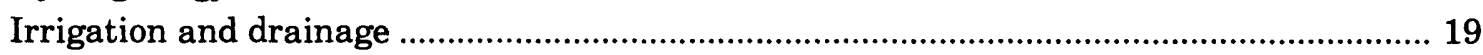

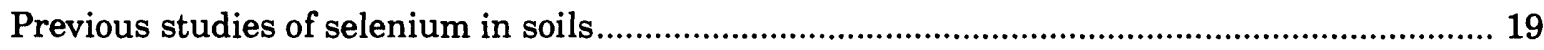

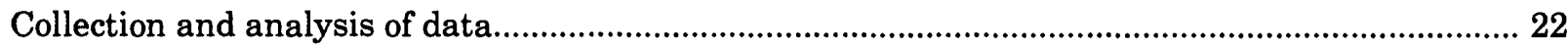

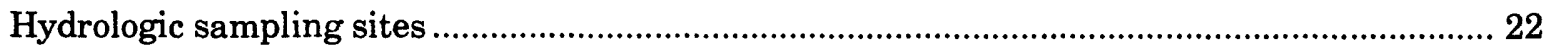

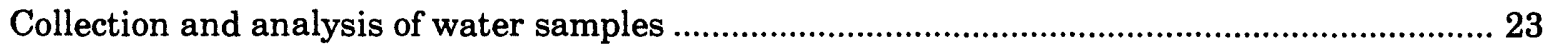

Criteria and standards used to evaluate elements in water............................................... 25

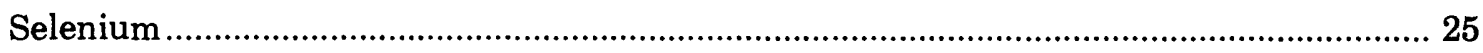

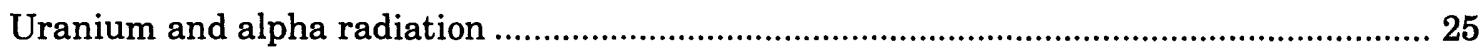

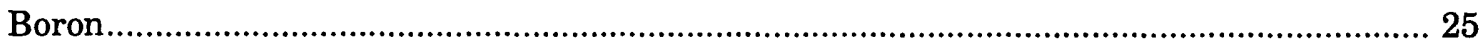

Collection and analysis of bottom sediment and core cuttings ........................................... 26

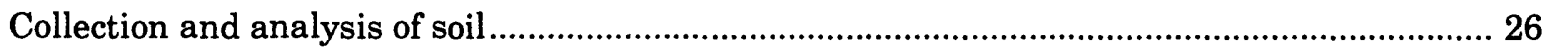

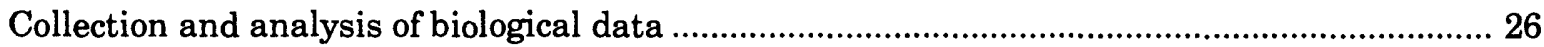

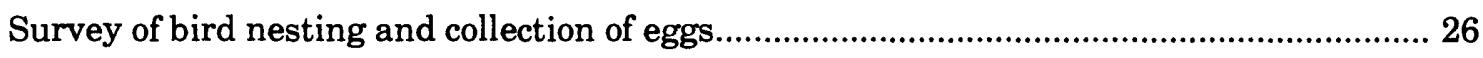

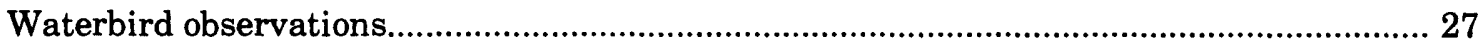

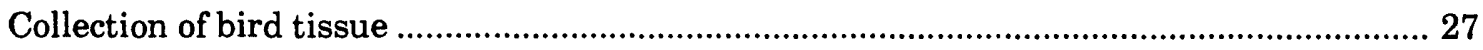

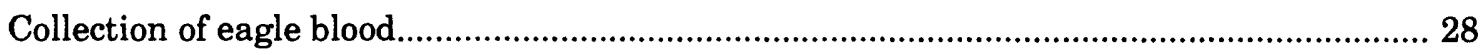

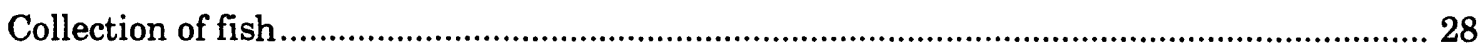

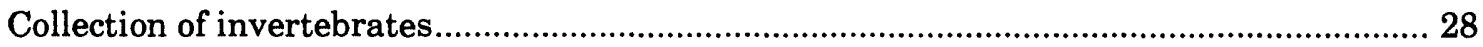

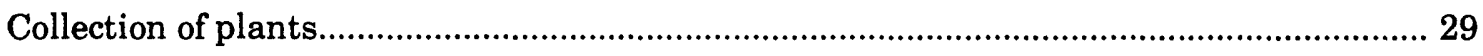

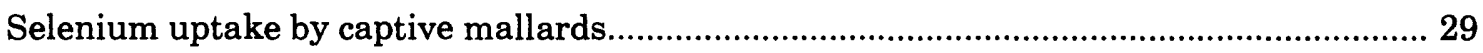




\section{CONTENTS-Continued}

Collection and analysis of data-Continued

Collection and analysis of biological data-Continued

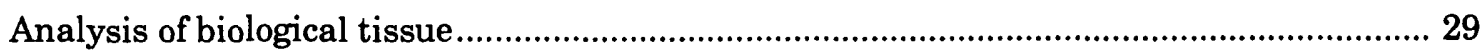

Preparation of figures using a geographic information system ............................................ 30

Hydrology and contaminants in biota in and near Stewart Lake Waterfowl

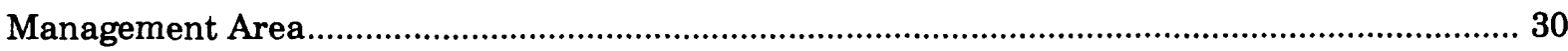

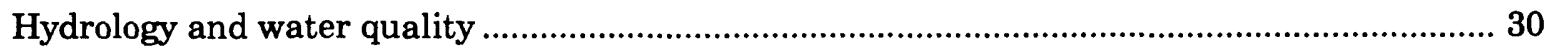

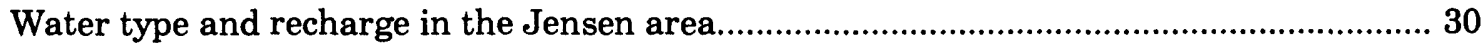

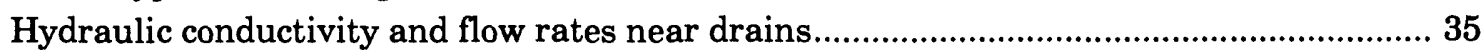

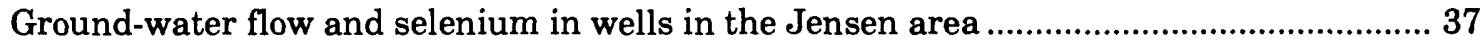

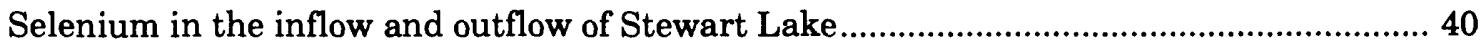

Trends in discharge, specific conductance, and selenium concentration in drainwater entering Stewart Lake ........................................................................... 41

Uranium and alpha radiation in water in the Jensen area............................................ 45

Selenium in bottom sediment from Stewart Lake ...................................................... 48

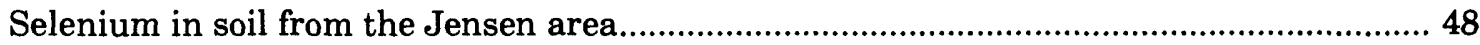

Association of total selenium in soil and water-extractable selenium ......................... 49

Association of selenium with soil type in the Jensen area ......................................... 55

Biological observations and contamination in biota ............................................................ 57

Nesting observations at marsh 4720 and Wheeler Pond near Stewart Lake

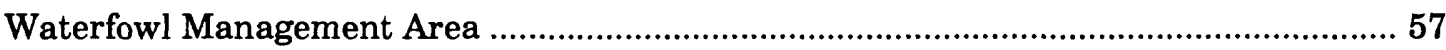

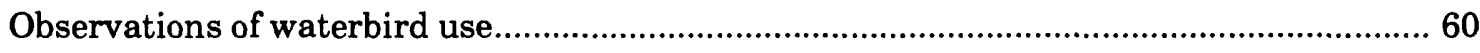

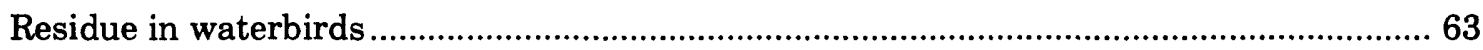

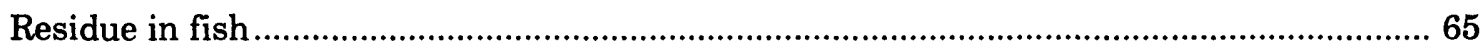

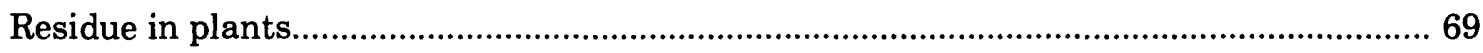

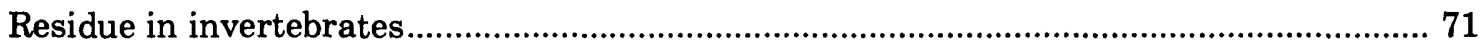

Hydrology and contaminants in biota in the Ashley Creek area .............................................. 73

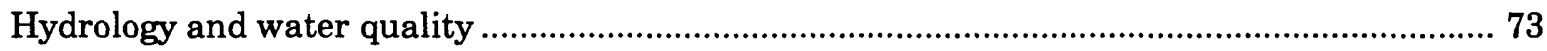

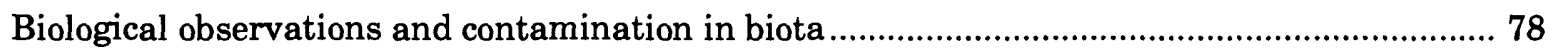

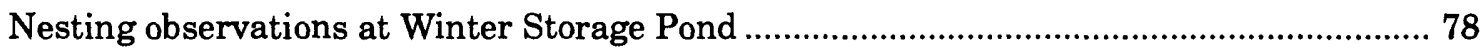

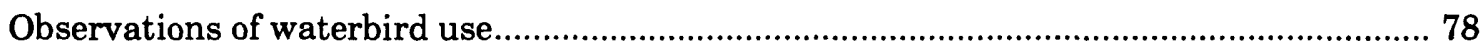

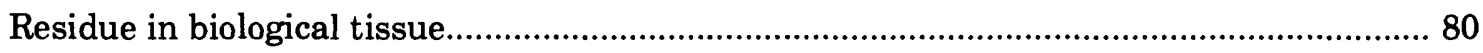

Hydrology and contaminants in biota in the area of Pelican Lake and Ouray

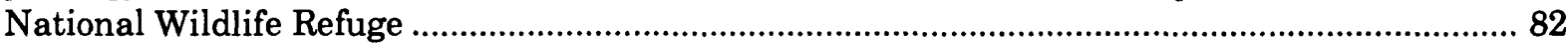

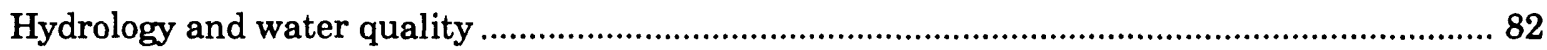

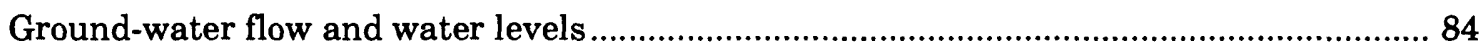

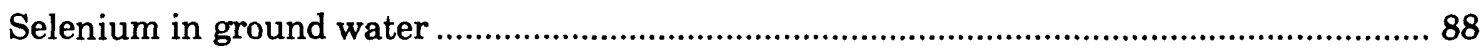

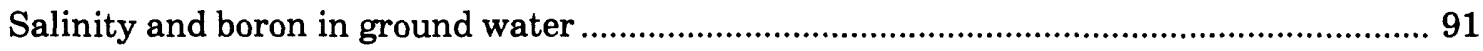

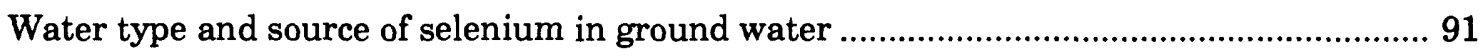

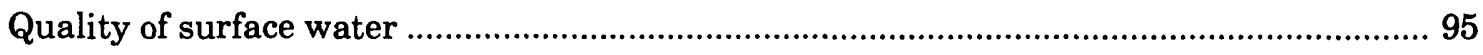

Water quality in Leota Bottom: an uncontaminated area ................................................. 96 


\section{CONTENTS-Continued}

Hydrology and contaminants in biota in the area of Pelican Lake and Ouray

National Wildlife Refuge-Continued

Hydrology and water quality-Continued

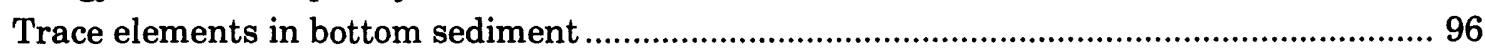

Association of selenium with soil type near Pelican Lake and Ouray ............................... 97

Biological observations and contamination in biota .......................................................... 100

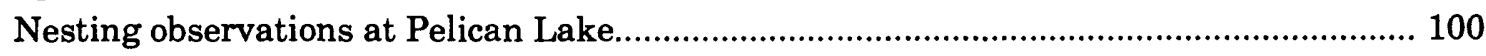

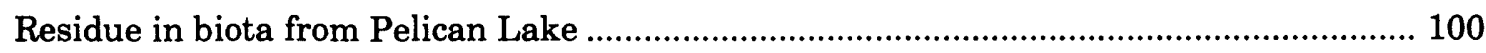

Nesting observations in Leota Bottom at Ouray National Wildlife Refuge ...................... 101

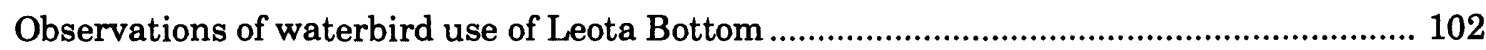

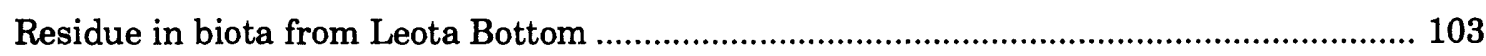

Nesting observations in Sheppard Bottom at Ouray National Wildlife Refuge................. 107

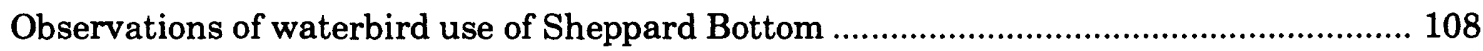

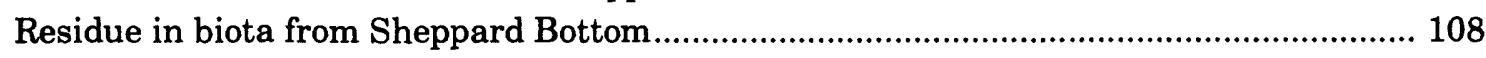

Nesting observations at the Roadside Ponds at Ouray National Wildlife Refuge ............. 114

Observations of waterbird use in the area of the Roadside Ponds ................................... 115

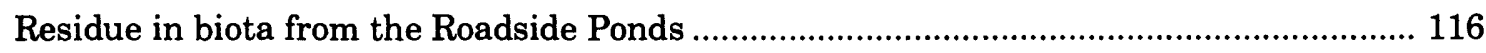

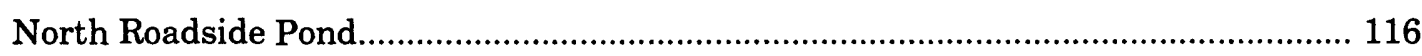

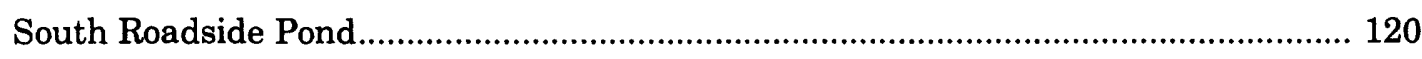

Bioconcentration of selenium at the Readside Ponds by captive mallards...................... 123

Selenium in biota from additional sites at Ouray National Wildlife Refuge..................... 127

Residue in bald and golden eagles at Ouray National Wildlife Refuge

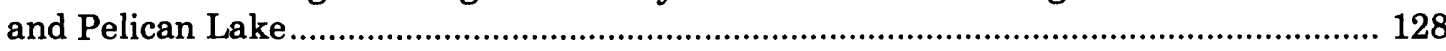

Hydrology and contaminants in biota in Pleasant Valley and Pariette Wetlands......................... 129

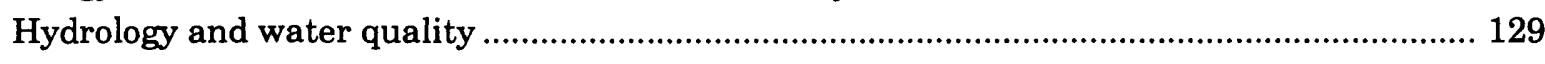

Trace elements in bottom sediment ............................................................................ 132

Association of selenium with soil type in the Pleasant Valley and Pariette

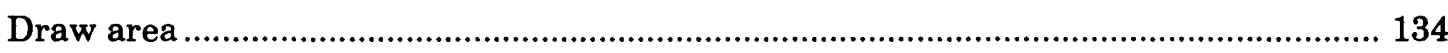

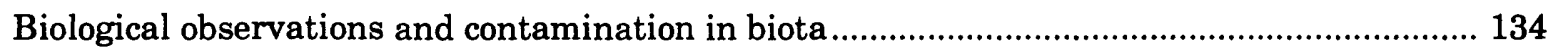

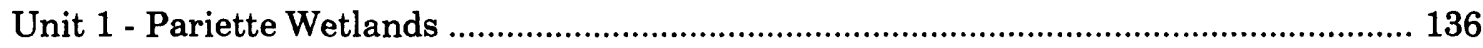

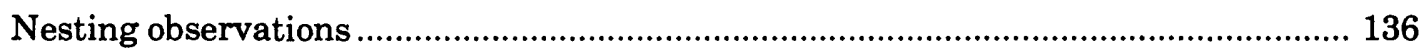

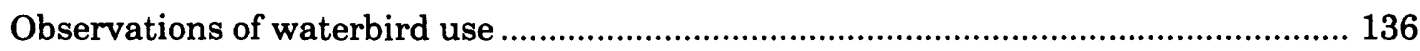

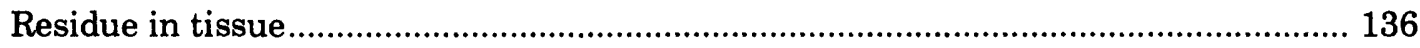

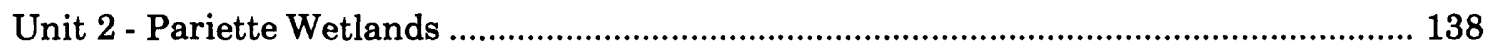

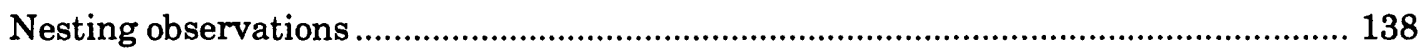

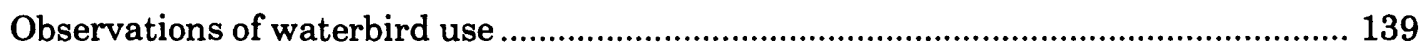

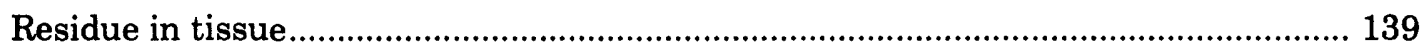

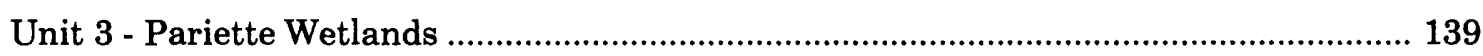

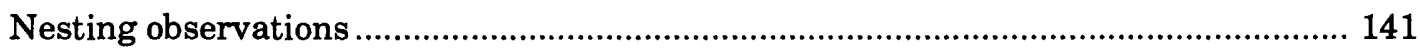

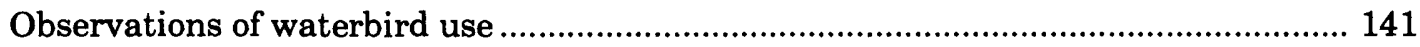

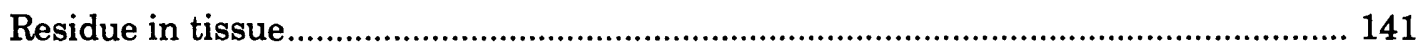

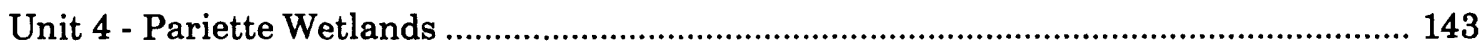

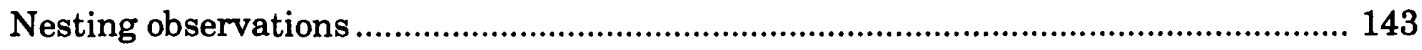




\section{CONTENTS-Continued}

Hydrology and contaminants in biota in Pleasant Valley and Pariette Wetlands - Continued

Biological Observations and Contamination in Biota-Continued

Unit 4 - Pariette Wetlands-Continued

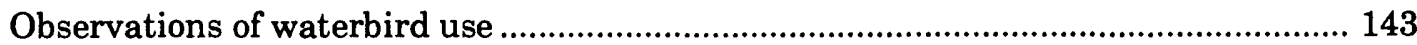

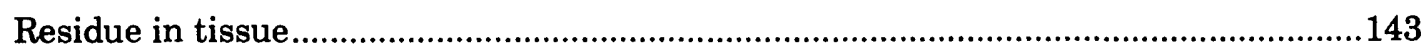

Streamflow, water quality, and biota of the Green River.................................................... 145

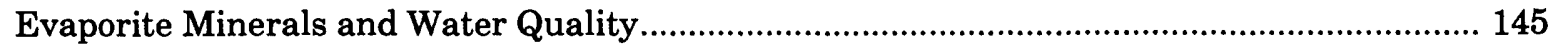

Trace Elements in Biota in the Green River.................................................................... 147

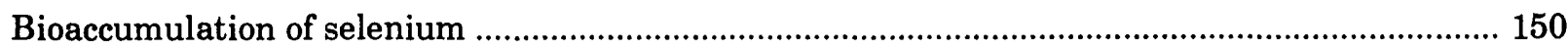

Selenium in the middle Green River basin and implications for human health......................... 152

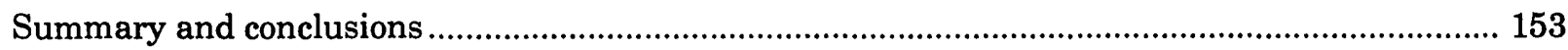

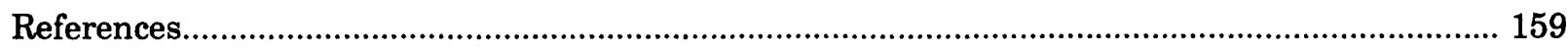

ILLUSTRATIONS

PAGE

Figures 1-9. Maps showing:

1. The Green River and major tributaries, and locations of national wildlife refuges, waterfowl management areas, and managed wetlands within the middle Green River basin

2. Banding locations of birds recovered in the middle Green River basin area ................. 6

3. Recovery locations of birds banded in the middle Green River basin area.................... 7

4. Locations of state and federal wildlife areas, potentially seleniferous geology, and irrigated croplands in Utah.

5. Locations of reservoirs and selected hydrologic features near Vernal and Jensen, Utah

6. Major trunk-line ground-water drains in the Jensen, Utah, area that enter Stewart Lake Waterfowl Management Area.

7. Canals and U.S. Bureau of Reclamation drains near Vernal, Utah

8. Selected data-collection sites at Ouray National Wildlife Refuge and Pelican

Lake

9. Locations of wells and surface-water and biological sampling sites and areas in Pleasant Valley and Pariette Wetlands south of Myton, Utah 


\section{ILLUSTRATIONS-Continued}

Figure

PAGE

10. Graph showing monthly discharge from Red Fleet Reservoir, water years 1986-89

11. Map showing locations of wells and surface-water and biological sampling sites in the area of Stewart Lake Waterfowl Management Area and Brush Creek near Jensen, Utah

12. Map showing locations of wells and surface-water and biological sampling sites in the area north of Stewart Lake Waterfowl Management Area, Jensen, Utah

13. Diagram showing concentrations of major ions in: a, canal water delivered to irrigated land near Stewart Lake; $b$, irrigation drainage discharged to Stewart Lake; and c, shallow ground water from a well near the J3 drain

14. Graph showing relation of selenium concentration to tritium units in water from Brush Creek and U.S. Bureau of Reclamation drains in the Jensen, Utah, area, August 1988

15. Graph showing relation of delta deuterium to delta oxygen-18 stable isotopes in irrigation water, drainwater, and well water in the Jensen, Utah, area

16. Boxplots showing values for hydraulic conductivity of wells in the major drain fields near Stewart Lake.

17. Map showing contours of the water table of shallow (0-50 feet) ground water near Stewart Lake Waterfowl Management Area in July 1989

18. Graph showing water levels in two wells in the Jensen, Utah, area

19. Boxplots showing selenium concentrations in well water from areas near Brush Creek and from five drain fields in Jensen, Utah, water years 1988-89.

20. Boxplots showing selenium concentrations in drainwater discharged to Stewart

Lake and in the outflow to the Green River for water years 1986-87 and

1988-89

Figures 21-28. Graphs showing:

21. Specific conductance and discharge for water entering Stewart Lake from the combined flows of the $\mathrm{J} 1$ and $\mathrm{J} 1 \mathrm{~A}$ drains

22. Specific conductance and discharge for water entering Stewart Lake from the J2 drain

23. Specific conductance and discharge for water entering Stewart Lake from the J3 drain

24. Specific conductance and discharge for water entering Stewart Lake from the J4 drain

25. Predicted and measured selenium concentrations discharged to Stewart

Lake from the J1 drain, 1980-89. 


\section{ILLUSTRATIONS-Continued}

Figure

PAGE

26. Predicted and measured selenium concentrations discharged to Stewart

Lake from the J2 drain, 1978-89.

27. Predicted and measured selenium concentrations discharged to Stewart

Lake from the J3 drain, 1981-89.

28. Predicted and measured selenium concentrations discharged to Stewart

Lake from the J4 drain, 1981-89.

29. Bar chart showing quantity of selenium removed from nine samples of soil using

three extraction procedures.

30. Graph showing relation of selenium yields obtained by 1:10 soil extractions to selenium yields obtained by saturation extractions

31. Map showing locations of soil of the Billings clay and Naples loam series in the Stewart Lake area and along Ashley Creek and its tributaries

32. Map showing locations of wells and surface-water and biological sampling sites along Ashley Creek and its tributaries.

33. Graph showing selenium concentrations in bottom sediment and cattails at several

distances from the outfall of drain J3 at Stewart Lake

Figures 34-36. Maps showing:

34. Locations of sample sites and selenium concentrations in surface water near Ashley Creek and its tributaries

35. Locations of 11 of the 25 U.S. Bureau of Reclamation drains in the Vernal, Utah, area and selenium concentrations in water from selected drains.

36. Contours of the water table of shallow (0-60 feet) ground water in the area of the Roadside Ponds and Sheppard Bottom at Ouray National Wildlife Refuge in April 1989.

Figures 37-41. Graphs showing:

37. Changes in water level in the Ag Field well and changes in mean daily discharge of the Green River near Jensen, Utah, 1989.

38. Selenium concentrations and water levels in the S3 and S5 wells in Sheppard Bottom at Ouray National Wildlife Refuge

39. Total monthly precipitation at Ouray $4 \mathrm{NE}$ weather station and water levels for shallow wells in the North Roadside draw at Ouray National Wildlife Refuge

40. Selenium concentrations and water levels in two wells in the North Roadside 3 draw at Ouray National Wildlife Refuge

41. Selenium concentrations and water levels in the Evans and Prairie Dog wells near Ouray National Wildlife Refuge, 1989 


\section{ILLUSTRATIONS-Continued}

Figure

PAGE

42. Boxplots showing selenium concentrations in water from wells in the area of Ouray National Wildlife Refuge, 1988-89

43. Graph showing selenium concentrations and water levels in shallow wells in the draw north of North Roadside Pond at Ouray National Wildlife

Refuge

44. Boxplots showing specific conductance in water from wells in the area of Ouray National Wildlife Refuge, 1988-89

45. Graph showing evaporative concentration of selenium and chloride in irrigationsource water (Pelican Lake) related to measured concentration of selenium and chloride in water from shallow wells in the area of Ouray National Wildlife Refuge.

46. Graph showing relation of delta deuterium to delta oxygen-18 for water samples

from Pelican Lake and wells at Ouray National Wildlife Refuge, 1988 and 1989.

47. Boxplots showing selenium concentrations in surface water entering Ouray

National Wildlife Refuge and in ponds in the Leota Bottom, Roadside Pond, and

Sheppard Bottom areas during 1988 and 1989

48. Graph showing concentrations of selenium and volatile solids in bottom sediment

from North and South Roadside Ponds at Ouray National Wildlife

Refuge.

Figures 49-51. Boxplots showing:

49. Selenium concentrations in American coot eggs from three ponds in Sheppard Bottom at Ouray National Wildlife Refuge

50. Selenium concentrations in non-randomly and randomly collected American coot eggs from North and South Roadside Ponds at Ouray National Wildlife Refuge.

51. Selenium concentrations in the livers of captive-reared mallards released at the Roadside Ponds in Ouray National Wildlife Refuge, 1989

Figures 52-54. Graphs showing:

52. Selenium concentrations in mallard livers after variable number of days of exposure.

53. Selenium concentrations in mallard breast muscle after variable number of days of exposure.

54. Weight loss in mallards exposed to naturally occurring selenium at the

Roadside Ponds in Ouray National Wildlife Refuge

55. Boxplots showing selenium concentrations in American coot eggs from ponds in

Pariette Wetlands, 1989 


\section{ILLUSTRATIONS-Continued}

Figure

PAGE

56. Graph showing maximum spring population count, total bird production, and num-

ber of breeding pairs of waterfowl at Pariette Wetlands, 1978-89.

57. Graph showing annual discharge of the Green River near Jensen, Utah, for water years 1947-89

Figures 58-60. Boxplots showing:

58. Dissolved-solids concentration in the Green River and in tributaries discharging to the Green River, water years 1988 and 1989

59. Selenium concentrations in the Green River and in tributaries discharging to the Green River, water years 1988 and 1989

60. Boron concentrations in the Green River and in tributaries discharging to the Green River, water years 1988 and 1989

Figures 61-64. Graphs showing:

61. Mean daily load of dissolved selenium in the Green River and in tributaries discharging to the Green River, water years 1988 and 1989

62. Selenium concentrations in fish collected at selected locations in the Green River in 1987

63. Geometric mean selenium concentrations in water, bottom sediment, and biota from Stewart Lake Waterfowl Management Area and Leota Bottom, an uncontaminated area of Ouray National Wildlife Refuge.

64. Geometric mean selenium concentrations in water, bottom sediment, and biota from the Roadside Ponds, Sheppard Bottom, and Leota Bottom at Ouray National Wildlife Refuge.

\section{TABLES}

Table

1. Annual water use and supply for Ouray National Wildlife Refuge, $1986-90 \ldots \ldots \ldots \ldots \ldots \ldots \ldots . . . . . . . . . . . .18$

2. Reporting levels for constituents determined in water and bottom sediment

3. Median discharges, median concentrations of selenium and chloride, and loads of selenium and chloride in drainwater entering Stewart Lake and in the outflow from the lake.

4. Results of the seasonal-Kendall test for trends in discharge and specific conductance for drains discharging to Stewart Lake

5. Selenium concentrations in drainwater and soil, and selenium concentrations and values of specific conductance and $\mathrm{pH}$ in extracts of soil, Mancos Shale, and salt efflorescence in the area of Jensen, Utah 


\section{TABLES-Continued}

Table

6. Selenium concentrations and values of specific conductance and $\mathrm{pH}$ in nativewater saturated soil and in soil that was dried and extracted using deionized water

7. Predicted ranges of saturation-extract yield of selenium from 1:10 extraction yields.

8. Nesting success of waterbirds at Stewart Lake and marsh $4720,1988-89$

9. List of species observed during waterbird counts at Stewart Lake and marsh 4720, and at Roadside Ponds and Sheppard Bottom at Ouray National Wildlife Refuge, 1988-89

10. Geometric mean selenium concentrations in bird eggs and bird tissue from Stewart Lake

11. Geometric mean selenium concentrations in biological samples collected from marsh 4720 and in fish samples collected nationwide by the National Contaminant Biomonitoring Program

12. Geometric mean selenium concentrations in fish samples collected from the north and south shores of Stewart Lake and the outlet to the Green River, and in fish samples collected nationwide by the National Contaminant Biomonitoring Program.

13. Geometric mean selenium concentrations in whole-body adult fish samples collected at several locations in Stewart Lake during spring and summer and in fish samples collected nationwide by the National Contaminant Biomonitoring Program

14. Geometric mean selenium concentrations in composite samples of plants and invertebrates collected from Stewart Lake...

15. Selenium concentrations in water, bottom sediment, and stems and roots of cattail (Typha sp.), and sediment carbon in samples collected at several distances from the outfall of the J3 drain at Stewart Lake.

16. Concentrations of dissolved selenium in tributaries discharging to Ashley Creek downstream of Steinaker Draw

17. Nesting success of waterbirds at the Winter Storage Pond, 1988-89

18. List of species observed during waterbird counts at the Winter Storage Pond near Ashley Creek, Leota Bottom, and at four pond units in Pariette Wetlands, 1988-89

19. Geometric mean selenium concentrations in biological samples from Winter Storage Pond and in fish samples collected nationwide by the National Contaminant Biomonitoring Program. 


\section{TABLES-Continued}

Table

20. Geometric mean selenium concentrations in samples of whole-body minnows and other small fish, plants (chara and potamogeton), and crayfish collected from Ashley Creek and in fish samples collected nationwide by the National

Contaminant Biomonitoring Program

21. Range of measurements for selected water-quality properties and constituents in water samples from two ponds (4 to 7 samples) in Leota Bottom and from the North and South Roadside Ponds (5 to 20 samples) at Ouray National Wildlife Refuge, 1987-89.....

22. Concentrations of trace elements and radionuclides in the less than 62-micron fraction of sediment samples collected from Leota L3 pond, S5 inflow canal, Sheppard S3 pond, North Roadside Pond, and North Roadside draw at Ouray National Wildlife Refuge

23. Nesting success of waterbirds at Pelican Lake, 1987

24. Geometric mean selenium concentrations in biological samples from Pelican Lake and in fish samples collected nationwide by the National Contaminant Biomonitoring Program.

25. Nesting success of selected waterbirds at Leota Bottom, Ouray National Wildlife Refuge, 1987-89.

26. Geometric mean selenium concentrations of American coot eggs collected at several locations in Leota Bottom, Ouray National Wildlife Refuge

27. Geometric mean selenium concentrations in several bird and fish samples collected from Leota Bottom at Ouray National Wildlife Refuge and in fish samples collected nationwide by the National Contaminant Biomonitoring Program

28. Geometric mean selenium concentrations in composite samples of plants and invertebrates collected from Leota Bottom at Ouray National Wildlife Refuge 106

29. Nesting success of selected waterbirds at Sheppard Bottom, Ouray National Wildlife Refuge, 1987-89 107

30. Geometric mean selenium concentrations in bird egg and bird tissue samples collected from Sheppard Bottom ponds S1, S2, S3, and S4 at Ouray National Wildlife Refuge.

31. Geometric mean selenium concentrations in bird egg and bird tissue samples collected from pond S5 in Sheppard Bottom at Ouray National Wildlife Refuge.

32. Geometric mean selenium concentrations in composite samples of whole-body fish, plants, and invertebrates collected from ponds S3 and S5 in Sheppard Bottom at Ouray National Wildlife Refuge and in fish samples collected nationwide by the National Contaminant Biomonitoring Program 


\section{TABLES-Continued}

Table

PAGE

33. Nesting success of selected waterbirds at the Roadside Ponds, Ouray National Wildlife Refuge, 1987-89

34. Geometric mean selenium concentrations in bird tissue samples collected from North Roadside Pond at Ouray National Wildlife Refuge.

35. Geometric mean selenium concentrations in biological samples collected from North Roadside Pond at Ouray National Wildlife Refuge.

36. Volatile-solids concentrations in sediment and selenium concentrations in sediment and plants from nine subsites at South and North Roadside Ponds, Ouray National Wildlife Refuge, March and April, 1989.

37. Selenium concentrations in samples of invertebrates (excluding snails) at the Roadside Ponds, Ouray National Wildlife Refuge, March-September, 1989

38. Geometric mean selenium concentrations in biological samples collected from South Roadside Pond and in fish samples collected nationwide by the National Contaminant Biomonitoring Program

39. Geometric mean selenium concentrations in tissue samples from captive-reared mallards collected on different dates.

40. Geometric mean concentrations of selected trace elements in blood of bald and golden eagles from areas near Pelican Lake and Ouray National Wildlife Refuge

41. Discharge and selected water-quality properties and constituents determined for water flowing into Pleasant Valley and Pariette Wetlands during 1987-89

42. Concentrations of elements and radionuclides in the less than 62-micron fraction of sediment samples collected from Redhead Pond and the desiltation pond at Pariette Wetlands related to the 95-percent confidence interval for soil in the Piceance Basin, Colorado, and the Uinta Basin, Utah

43. Geometric mean selenium concentrations in biological samples collected from the flood control, desiltation, North Felters, and Felters Ponds, in Big Wash in Pariette Wetlands (Unit 1), and in fish samples collected nationwide by the National Contaminant Biomonitoring Program

44. Geometric mean selenium concentrations in biological samples collected from Gadwall and Redhead Ponds in Pariette Wetlands (Unit 2) and in fish samples collected nationwide by the National Contaminant Biomonitoring Program

45. Geometric mean selenium concentrations in biological samples collected from Big Island, Small Island, Horseshoe, Mallard, Indian, and Roadside Cliff Ponds in Pariette Wetlands (Unit 3) and in fish samples collected nationwide by the National Contaminant Biomonitoring Program 


\section{TABLES-Continued}

Table

PAGE

46. Geometric mean selenium concentrations in biological samples collected from

Pintail and Shoveler Ponds in Pariette Wetlands (Unit 4)

47. Mean daily discharge, mean dissolved-solids and selenium concentrations, and mean daily dissolved-solids and selenium load in the Green River and its major tributaries, water years 1988 and 1989

48. Selenium concentrations in human food items from selected areas in the middle Green River basin and the quantity of each that could be consumed without exceeding a safe and adequate daily quantity recommended for an adult male. 


\section{CONVERSION FACTORS, VERTICAL DATUM, AND ABBREVIATED WATER-QUALITY UNITS}

\section{Multiply}

acre

acre-foot (acre-ft)

cubic foot per second $\left(\mathrm{ft}^{3} / \mathrm{s}\right)$

foot per mile $(\mathrm{ft} / \mathrm{mi})$

foot $(\mathrm{ft})$

gallon per minute (gal/min)

gallon per hour (gal/hr)

inch (in.)

mile (mi)

ounce (oz)

square mile $\left(\mathrm{mi}^{2}\right)$

ton

yard (yd)
By

4,047

1,233

.02832

.1894

.3048

3.748

224.9

25.4

2.54

.0254

1.609

28.35

2.59

.907

.9144

\section{To obtain}

square meter

cubic meter

cubic meter per second

meter per kilometer

meter

liter per minute

liter per hour

millimeter

centimeter

meter

kilometer

gram

square kilometer

metric ton

meter

Water temperature is given in degrees Celsius $\left({ }^{\circ} \mathrm{C}\right)$, which can be converted to degrees Fahrenheit $\left({ }^{\circ} \mathrm{F}\right)$ by the following equation:

$$
{ }^{\circ} \mathrm{F}=1.8\left({ }^{\circ} \mathrm{C}\right)+32 .
$$

Sea level: In this report "sea level" refers to the National Geodetic Vertical Datum of 1929 -a geodetic datum derived from a general adjustment of the first-order level nets of the United States and Canada, formerly called Sea Level Datum of 1929.

Chemical concentration and water temperature are given only in metric units. Chemical concentration in water is given in milligrams per liter $(\mathrm{mg} / \mathrm{L})$ or micrograms per liter $(\mu \mathrm{g} / \mathrm{L})$. Milligrams per liter is a unit expressing the solute per unit volume (liter) of water and is about the same as parts per million unless concentrations are greater than 7,000 milligrams per liter. One thousand micrograms per liter is equivalent to 1 milligram per liter. Radioactivity is expressed in picocuries per liter $(\mathrm{pCi} / \mathrm{L})$, which is the amount of radioactive decay producing 2.2 disintegrations per minute in a unit volume (liter) of water. Stable isotope concentration is reported as permil, which is equivalent to parts per thousand. Chemical concentration in sediment and biological tissues is given in milligrams per kilogram $(\mathrm{mg} / \mathrm{kg}$ ) or micrograms per gram $(\mu \mathrm{g} / \mathrm{g})$, which are both equal to parts per million (ppm); or micrograms per kilogram $(\mu \mathrm{g} / \mathrm{kg})$, which is equal to parts per billion (ppb). Specific conductance is given in microsiemens per centimeter $(\mu \mathrm{S} / \mathrm{cm})$ at 25 degrees Celsius. 


\title{
DETAILED STUDY OF SELENIUM AND SELECTED ELEMENTS IN WATER, BOTTOM SEDIMENT, AND BIOTA ASSOCIATED WITH IRRIGATION DRAINAGE IN THE MIDDLE GREEN RIVER BASIN, UTAH, 1988-90
}

\author{
By Doyle W. Stephens, U.S. Geological Survey \\ Bruce Waddell, U.S. Fish and Wildlife Service \\ Lorri A. Peltz, U.S. Geological Survey \\ Jerry B. Miller, U.S. Bureau of Reclamation
}

\begin{abstract}
Studies completed at Stewart Lake Waterfowl Management Area, lower Ashley Creek, Ouray National Wildlife Refuge, and Pariette Wetlands identified several areas where selenium was adversely affecting water quality and creating a hazard to wildlife. The source of contamination at Stewart Lake is drainwater and shallow ground water from soils derived from Mancos Shale. Median selenium concentrations in all drainwater discharged to Stewart Lake exceeded the State standard of 5 micrograms per liter established for wildlife protection. Selenium concentrations in all biological tissues sampled at Stewart Lake Waterfowl Management Area were large compared to concentrations in biota from most other sites in the middle Green River basin.
\end{abstract}

Selenium concentrations in Ashley Creek upstream of the city of Vernal generally were less than 1 microgram per liter but 12 miles downstream averaged 73 micrograms per liter. The source of the contamination was believed to be from inflows of shallow ground water and surface water originating as seepage from a sewage-lagoon system that flows through Mancos Shale and mobilizes selenium. Waterfowl from the area contained selenium concentrations as large as 27.2 micrograms per gram in muscle tissue, and an eared grebe egg contained 71 micrograms per gram.

Selenium contamination of ponds at Ouray National Wildlife Refuge was limited to a small area on the western part of the refuge and was due to seepage of shallow ground water into waterfowl ponds. Geometric mean concentrations in plants, invertebrates, bird eggs, and fish from the North and South Roadside Ponds were larger than concentrations known to cause reproductive failure in mallards (Anas platyrhyncos). Mallards exposed during a field experiment at the Roadside Ponds quickly accumulated selenium in body tissues and died by the fourth week.

Water-quality deterioration in Pariette Wetlands was believed to be due to the discharge of tailwater and accrual of ground water into the area. Selenium concentrations in biota from Pariette Wetlands ranged from near background to levels known to have adverse effects.

\section{INTRODUCTION}

During the last several years there has been increasing concern about the quality of irrigation drainwater and its potential effects on human health, fish, and wildlife. Large selenium concentrations have been detected in subsurface drainage water from irrigated land in western San Joaquin Valley in California. In 1983, incidences of mortality, birth defects, and reproductive failures in waterfowl were discovered by the U.S. Fish and Wildlife Service at the Kesterson National Wildlife Refuge in the western San Joaquin Valley where drainage water was impounded. In addition, potentially toxic trace elements and pesticide residues have been detected in other areas in western states that receive irrigation drainage.

Because of the concern that problems related to selenium or other trace inorganic or organic constituents in irrigation drainage might not be limited to the Kesterson Reservoir area, the U.S. Department of the Interior (DOI) began a program in 1985 to determine whether irrigation-related 
problems existed at other Department constructed or managed irrigation projects, national wildlife refuges, or other wetland areas for which the DOI has responsibilities under the Migratory Bird Treaty Act, the Endangered Species Act, or other legislation. Assistance in structuring and evaluating the program was provided by the National Research Council's Committee on Irrigation-Induced Water Quality Problems (National Research Council, 1989). As the program evolved, it became a five-phase process: (1) site identification, (2) reconnaissance investigations, (3) detailed studies, (4) planning, and (5) remediation. Activities in the first three phases are conducted by study teams composed of scientists from the U.S. Geological Survey (USGS), the U.S. Fish and Wildlife Service (USFWS), the U.S. Bureau of Reclamation (USBOR), and the U.S. Bureau of Indian Affairs (USBIA). During phases 1-3, a USGS scientist heads each study team. Activities for phases 4 and 5 are conducted by the USBOR.

Initially, 20 locations in 13 states were identified that warranted reconnaissance investigations. Nine of the 20 locations were selected for initiation of reconnaissance investigations in 1986. The investigations were directed toward determining whether irrigation drainage (1) has caused or has the potential to cause significant harmful effects on human health, fish, and wildlife, or (2) may adversely affect the suitability of water for other uses. The reconnaissance investigations indicated there were sufficient problems to warrant further investigation at:

Stillwater Wildlife Management Area, Nevada

Salton Sea area, California

Middle Green River basin area, Utah

Kendrick Project Area, Wyoming

This report presents the results of the detailed study of the middle Green River basin area, Utah, done during 1988-90. Although the emphasis of the report primarily concerns data collected during 1988 and 1989, some data from 1986 and 1987 are included. The report discusses issues of irrigation-related contamination, primarily due to selenium. The results of the 1986-87 reconnaissance study were reported by Stephens and others (1988a). Further analysis of the hydrologic and biologic data are given in Stephens and others (1988b) and Stephens and Waddell (1989). All hydrologic and biologic data collected during the detailed study of the middle Green River basin are compiled in a separate data report (Peltz and Waddell, 1991).

\section{Purpose and Scope of the Detailed Study}

The purpose of the detailed investigation was (1) to define the extent and severity of existing irrigation-induced water-quality problems or the potential for future problems, and (2) provide the scientific understanding needed for development of alternatives to mitigate or resolve identified problems. The specific areas studied in the middle Green River basin were Stewart Lake Waterfowl Management Area (WMA) and Ouray National Wildlife Refuge (NWR). Reconnaissance at Pariette Wetlands was expanded to include upstream agricultural areas in Pleasant Valley, and additional data were collected for lower Ashley Creek and marsh 4720. Specific objectives for this study were to:

1. Determine the sources of selenium entering Stewart Lake, lower Ashley Creek and marsh 4720, and the Roadside Ponds-Sheppard Bottom complex at Ouray NWR.

2. Determine the age and mechanism of hydrologic transport of water containing selenium in the drains discharging to Stewart Lake.

3. Determine the accumulation and potential for mobilization of selenium from sediment in Stewart Lake and the Roadside Ponds at Ouray NWR.

4. Establish a baseline for boron, selenium, and uranium concentrations in water, sediment, and biota for the Leota Bottom area of Ouray NWR that may be used to interpret data from contaminated sites in Ouray NWR and Stewart Lake WMA. 
5. Prepare maps relating such environmental factors as irrigation, geology, and climate to selenium concentrations in the middle Green River drainage.

6. Determine if differences in waterbird production exist between selenium-contaminated areas at Stewart Lake WMA and the Roadside Ponds at Ouray NWR, and the uncontaminated area at Leota Bottom (Ouray NWR), and determine biological accumulation and distribution of selenium in the food chain at Stewart Lake WMA and Ouray NWR.

7. Determine the effects of selenium on the nesting tenacity and post-hatch movements of migratory birds at Stewart Lake WMA and at Ouray NWR.

8. Evaluate the effect of selenium on mallards in a field environment at Stewart Lake WMA and Ouray NWR by conducting field experiments to compare with experimental studies of effect of selenium previously done in a laboratory setting.

9. Determine if selenium or boron adversely affect water quality and wildlife at Pariette Wetlands and if irrigation return flow or drainage from USBOR facilities in Pleasant Valley is responsible for the condition.

Reconnaissance sampling in 1987 at Browns Park NWR in the northern part of the middle Green River basin (fig. 1) showed that concentrations of major elements and selected trace elements in impoundments and in water supplied to the refuge were within State and Federal standards established for wildlife protection. Concentrations of selected trace elements in fish and waterfowl from the refuge did not approach concentrations known to have adverse effects on those organisms.

Samples of waterfowl from Desert Lake WMA in the southern part of the middle Green River basin (fig. 1) collected in 1985 indicated selenium was present in coot livers at concentrations that exceeded normal background values. Limited sampling of impounded and inflowing water from the area in 1986-87 indicated possible problems only with selenium. Selenium concentrations in the water ranged from 1 to $12 \mu \mathrm{g} / \mathrm{L}$ with a mean of about $5 \mu \mathrm{g} / \mathrm{L}$. Selenium concentrations in coot livers ranged from 5 to $8.5 \mu \mathrm{g} / \mathrm{g}$ (dry weight). Although these concentrations are larger than typical background concentrations, they did not appear to adversely affect the population. Desert Lake WMA, therefore, was not investigated as part of the detailed study.

The detailed study involved the collection and analysis of physical, chemical, and biological data from Stewart Lake WMA, Ashley Creek-marsh 4720, and Ouray NWR; and continued reconnaissance near Pariette Wetlands. These areas represent four different geological settings and different water source and delivery systems, yet all are similar biologically. Although each of the areas is affected to varying degrees and each has different sources for the contaminants, the substances of concern, and exposure pathways for biota are similar for all areas.

\section{Acknowledgments}

Appreciation is extended to Boyd Snow and other property owners adjacent to Stewart Lake WMA and Ouray NWR for allowing access to their land and the installation of monitoring wells. Special thanks to Neil Folks, area manager for Stewart Lake WMA, and to Keith Hansen and Richard Sjostrom, refuge managers for Ouray NWR, for providing information, personnel, facilities, and equipment that greatly aided this study, and to William Stroh, U.S. Bureau of Land Management (USBLM), for providing waterfowl population information for Pariette Wetlands. Additional funding was provided by the USFWS for the study of contaminants at refuges. 


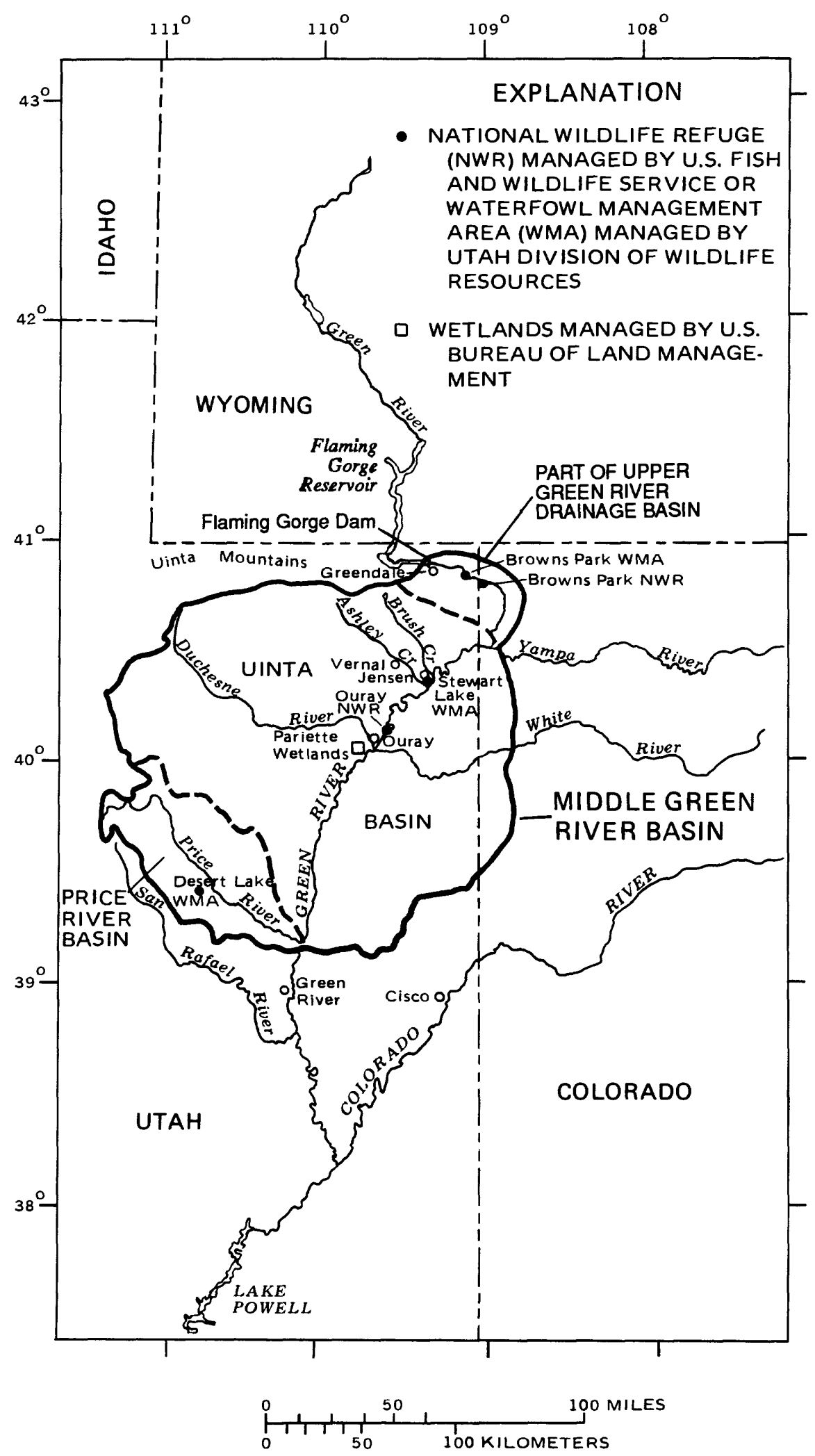

Figure 1. The Green River and major tributaries, and locations of national wildlife refuges, waterfowl management areas, and managed wetlands within the middle Green River basin. 


\section{Location and Wildlife Use of the Middle Green River Basin}

The Green River and its tributaries drain an area of nearly $45,000 \mathrm{mi}^{2}$ in Wyoming, Colorado, and Utah. The middle Green River basin is operationally defined as an area of about $12,500 \mathrm{mi}^{2}$ that consists of the drainage of the main stem of the Green River and its tributaries between Flaming Gorge Reservoir and the confluence of the Price and Green Rivers 15 mi north of the city of Green River, Utah (fig. 1). It consists of the Uinta Basin $\left(10,000 \mathrm{mi}^{2}\right)$ and the Price River basin $\left(1,900 \mathrm{mi}^{2}\right)$ plus a small section $\left(600 \mathrm{mi}^{2}\right)$ of the upper Green River drainage basin from Flaming Gorge Dam to the ColoradoUtah border.

There are six state- or federally managed waterfowl areas in the middle Green River basin: Browns Park and Ouray NWRs, and Browns Park, Stewart Lake, and Desert Lake WMAs. Pariette Wetlands is a USBLM wetland complex of 9,000 acres on Pariette Wash about 35 mi southwest of Vernal. These areas support feeding, resting, and nesting habitat for migrating waterfowl along the Green River corridor. No specific figures were found for numbers of waterfowl using this corridor, but personnel at the Ouray NWR estimated the refuge had over 7,000,000 use-days for marsh and waterbirds, shorebirds, raptors, waterfowl, geese, and coots combined in 1989 . Use appeared to be less than in 1988 when it was estimated that there were over $1,250,000$ use-days by waterfowl alone.

Migration pathways are complex and not clearly delineated for this area (Bellrose, 1976). Data for band returns were obtained and plotted showing the banding locations of birds that were harvested in the vicinity of the study area (fig. 2). Birds harvested in the general vicinity of the study area appear to have been banded in a large area covering the northern Rocky Mountain states and Canada. Some of the sites where birds were banded appear closely associated with other areas having water and soils that contain large selenium concentrations. Birds banded in the vicinity of the study area were similarly found to spread to a large area (fig. 3). Some of the band returns for Canada geese show winter use in the vicinity of the Salton Sea in southern California, an area also being studied as part of the DOI Irrigation Drainage Program because of potential contamination by selenium.

\section{Climate}

The low-elevation or basin lands along the Green River are arid to semiarid, and the climate gradually becomes more humid with increased elevation. The average annual precipitation in the lower elevations of the area (1951-80) ranged from $7.55 \mathrm{in}$. at Jensen to $6.04 \mathrm{in}$. at the city of Green River, Utah. Storms from the northwest during October through April account for about 60 percent of the average annual precipitation (Fields and Adams, 1975). Precipitation in the high west-central part of the Uinta Mountains is greater than 38 in. annually. Potential evapotranspiration in the valley at Ouray NWR is nine times the average annual precipitation of 8 in., or about 72 in. (Hood and Fields, 1978 , p. 9). Thus, precipitation at the lower elevations is mainly lost by evaporation and transpiration and is not a source of water for streams or ground-water recharge, and the precipitation at higher elevations, where potential evapotranspiration is less than precipitation, provides surface and ground water for most of the basin.

The area has hot summers and cold winters. Winter temperatures commonly are less than $0{ }^{\circ} \mathrm{F}$, and summer temperatures commonly exceed $90^{\circ} \mathrm{F}$. Average annual air temperatures along the Green River (1951-80) range from $45^{\circ} \mathrm{F}$ at Jensen to $52^{\circ} \mathrm{F}$ at the city of Green River, Utah (National Oceanic and Atmospheric Administration, 1982).

\section{Hydrogeology}

The Uinta Basin encloses a partially dissected sequence of Tertiary rocks deposited in a subsiding trough with an east-west axis that parallels the axis of the Uinta Mountains. Intermittent uplift and other structural events not only led to large-scale erosion of the rocks of early Tertiary age but also faulted, fractured, and folded them. Rocks cropping out in the northern Uinta Basin range in age from Precambrian to Holocene. The exposed section has a composite thickness in the northwestern 


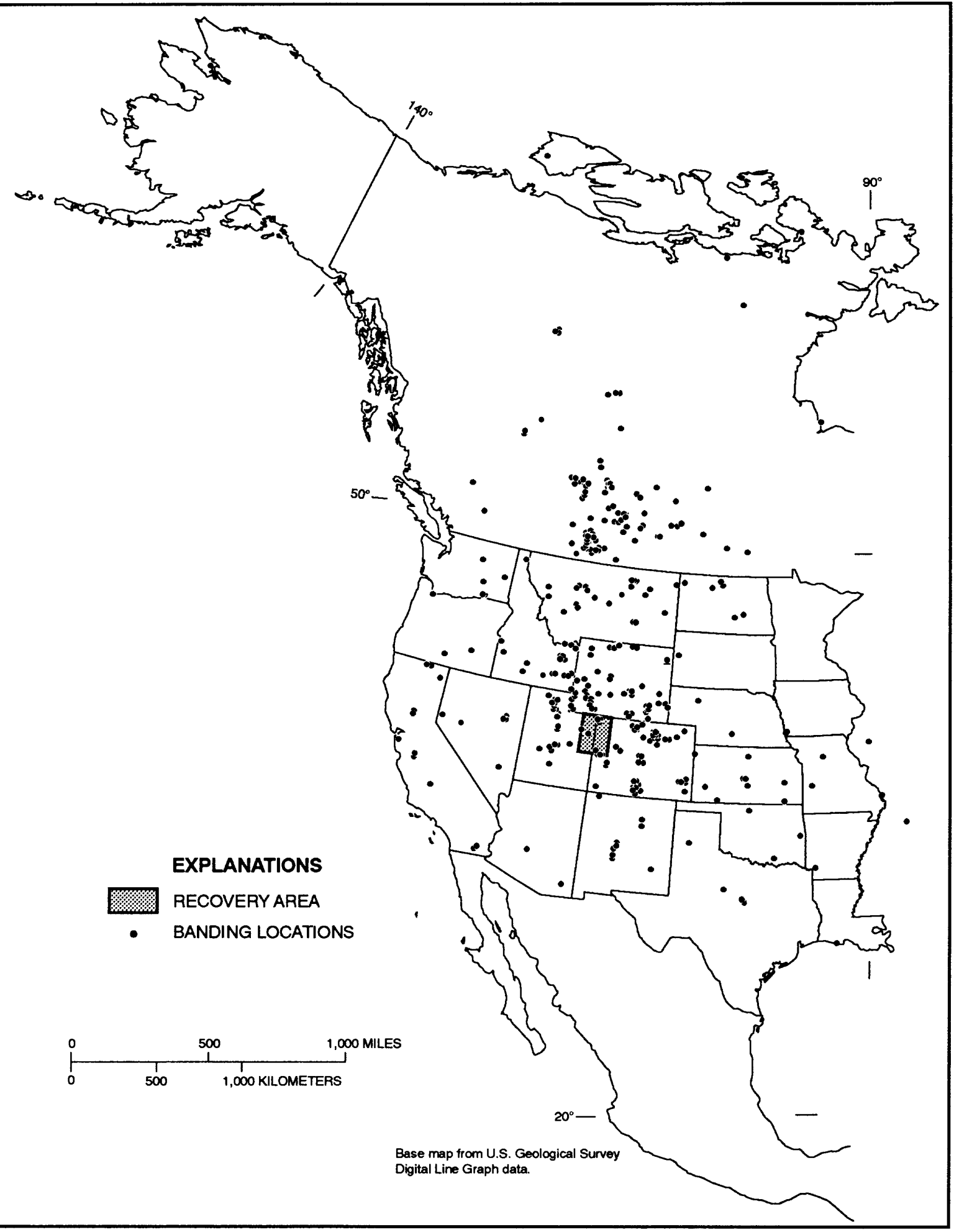

Figure 2. Banding locations of birds recovered in the middle Green River basin area. 


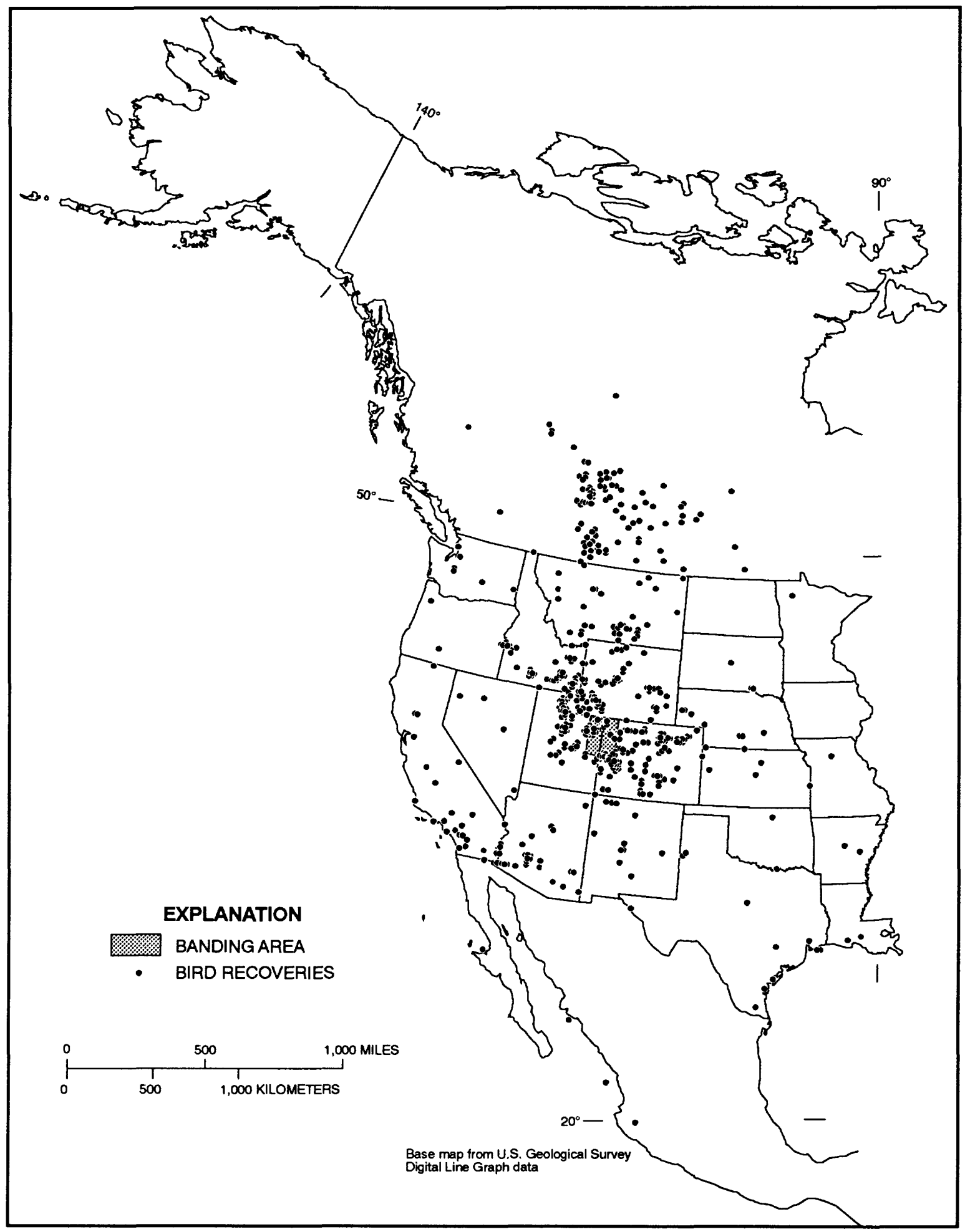

Figure 3. Recovery locations of birds banded in the middle Green River basin area. 
part of the basin of about 58,000 ft and in the eastern part of the basin of about 53,000 $\mathrm{ft}$ (Hood and Fields, 1978, p. 6). The thickness and hydrologic characteristics of the rock units in the northern part of the basin were described by Hood (1976), and in the southern part of the basin by Price and Miller (1975). The geology of the basin has been extensively studied for its oil and gas deposits (Intermountain Association of Petroleum Geologists, 1964; Intermountain Association of Geologists, 1969; Utah Geological Association, 1985). The surficial geology of the area from Flaming Gorge Dam to Pariette Draw has been mapped by Carrara (1980) and the underlying geologic structure by Rowley and others (1985).

Glaciation during Pleistocene time carved the Uinta Mountains to approximately their current form and provided the debris from which the major unconsolidated hydrologic units of Quaternary age in the northern part of the basin are formed. Seven of the geologic units or their equivalents are considered to be sources of water or to have significant effects on the ground water of the basin. Eight other units or their equivalents are classed as important aquifers. The remaining units have small permeability and either inhibit recharge or deter ground-water movement (Hood and Fields, 1978, p. 8). Several units contain evaporites that greatly degrade the quality of the water moving through them (Hood and Fields, 1978, p. 8). These evaporites, primarily from the Mancos Shale of Cretaceous age, create the water-quality problems associated with irrigation return flows in the area.

The headwater areas of the Price River basin are characterized by Tertiary and Cretaceous age rocks: Green River, Colton, and North Horn Formations, and Flagstaff Limestone. These include some volcanic rocks, dikes, and sills of Tertiary age. The Book Cliffs, a prominent escarpment that roughly parallels the Price River, is formed from the Mesaverde Group including the Price River and Blackhawk Formations and the Castlegate Sandstone of Cretaceous age. Exposed rock in the area includes limestone, sandstone, mudstone, siltstone, shale, conglomerate, and coal. The Blackhawk Formation is the most important coal deposit in the state. Pediment and lowlands are largely Mancos Shale that consists of the Masuk, Emery Sandstone, Garley Canyon Sandstone, Blue Gate, Ferron Sandstone, and Tununk Members. A small area between the Desert Lake WMA and the Green River is Dakota Sandstone of Cretaceous age and Hermosa Formation of Pennsylvanian age (Waddell and others, 1981).

Most springs in the headwater areas of the Price River issue from the Star Point Sandstone and contain less than $1,000 \mathrm{mg} / \mathrm{L}$ of dissolved solids. The Blackhawk Formation also produces some water associated with the coal. The Ferron Sandstone member of the Mancos Shale is the most important water producer in the area and crops out in the lowland areas. Various members of the Mancos Shale typically have small permeability, erode easily, and contain considerable calcium and sodium sulfate minerals, as well as selenium. Most of the shallow ground water in the lowlands typically contains in excess of $2,000 \mathrm{mg} / \mathrm{L}$ dissolved salts. The "badlands" topography and landscape of the lowlands is a result of the erodibility, salt content, and small permeability of these shales. Most precipitation quickly runs off, carrying large quantities of sediment and salts into surface waters.

While there are many areas in Utah where crops are irrigated, established wildlife areas exist, and selenium is present in geologic formations, these conditions are coincident most often in the middle Green River basin (fig. 4). Basin lowlands receive small quantities of precipitation, have large rates of evaporation, and contain soils derived from evaporite deposits. Although selenium occurs in many rocks formed during the Carboniferous to Quaternary Periods, most study has focused on the Cretaceous Period, and more is known about the distribution of seleniferous plants on rocks of Cretaceous age in the western United States than on rocks of any other period (Berrow and Ure, 1989, p. 219). 


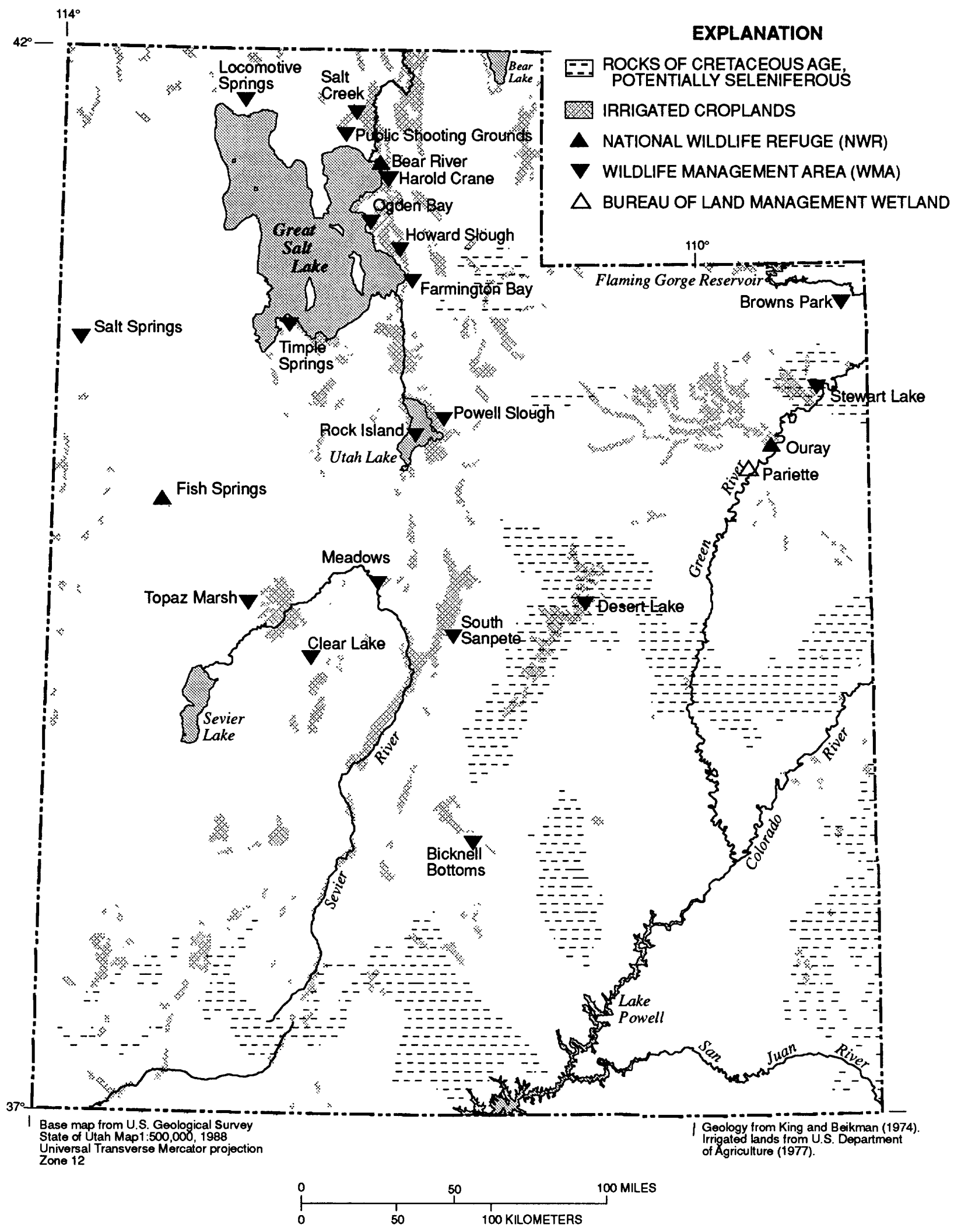

Figure 4. Locations of state and federal wildlife areas, potentially seleniferous geology, and irrigated croplands in Utah. 


\section{Stewart Lake Waterfowl Management Area}

\section{Location and Wildlife Use}

Stewart Lake WMA, adjacent to the Green River (fig. 5) and $12 \mathrm{mi}$ south of Vernal near Jensen, Utah, is operated by the Utah Division of Wildlife Resources. Stewart Lake has a surface area of 250 acres and occupies most of the Stewart Lake WMA. Little active water management occurs at Stewart Lake, but the lake is occasionally flushed when the level of the Green River rises, which it did annually from 1983 to 1986.

Waterfowl use near Stewart Lake WMA is concentrated during periods of migration and during the breeding season. Few wildlife-use counts have been made for this area. About 700-800 adult and young ducks, coots, and geese formerly used the lake for breeding and nesting during the summer. Waterfowl species nesting here in significant numbers include coot, mallard, and gadwall. The adjacent Green River provides limited winter habitat for Canada geese and ducks. Four species of endangered fish occur in this area of the Green River: Colorado squawfish (Ptychocheilus lucius); humpback chub (Gila cypha); bonytail chub (G. elegans); and razorback sucker (Xyrauchen texanus). A species that is a candidate for listing as endangered, the flannel-mouth sucker (Catostomus latipinnis) also occurs in the area.

\section{Hydrogeology and Soils}

The Mancos Shale is the most common formation in the Jensen area and is more than $5,000 \mathrm{ft}$ thick (Untermann and Untermann, 1954, p. 63). It is the formation on which the Green River flows in much of the area. The Mancos Shale consists of gray- and yellow-weathering, soft, calcareous shales of marine origin and contains a few sandstone lenses and nodular calcareous beds. Thin calcareous seams, selenite gypsum, and epsomite, commonly occur in the Mancos Shale. The shales decrease in thickness toward the Jensen Syncline and, where exposed, weather easily. The agricultural land of the Jensen Valley overlies this formation. Where drainage is poor, soils derived from Mancos Shale are saline and support vegetation consisting chiefly of salt-brush types. Soils derived from Mancos Shale also contain considerable selenium. Geochemical data on soils developed on Mancos Shale 100 $\mathrm{mi}$ south of Jensen near Cisco indicate the soils contain total selenium concentrations ranging from 4 to 5.6 parts per million (ppm, also equivalent to $5.6 \mu \mathrm{g} / \mathrm{g}$ ) (Rosenfeld and Beath, 1964, p. 45). By comparison, the average selenium concentration in typical shale is $0.6 \mathrm{ppm}$ (Drever, 1982, p. 298).

Land near Jensen is on upper and lower benches. The bench soils were developed on alluvial material of recent geologic origin that has been modified and reworked by the Green River. The soils have no distinct profile patterns or horizons. Areas of deep, fine-textured soils are often in close proximity to areas of coarse-textured soils or shallow soils overlying gravel of up to cobble size.

\section{Irrigation and Drainage}

Prior to the1963 USBOR completion of Steinaker Reservoir 4 mi north of Vernal, Ashley Creek provided the surface inflow into Stewart Lake. Most of the water in Ashley Creek now is diverted into the USBOR's Steinaker Reservoir, and the lower channel of Ashley Creek bypasses Stewart Lake on the west side to discharge directly into the Green River (fig. 5). Since 1979, the only source of surface inflow to Stewart Lake has been discharge from the USBOR drains in the Jensen area. The water is supplied as mitigation for Ashley Creek water now diverted to Steinaker Reservoir.

The Jensen Unit of the USBOR's Central Utah Project provides irrigation water from Red Fleet Reservoir via Brush Creek for about 4,000 acres near Stewart Lake WMA. About 90 percent of the land is a supplemental-service area that receives only part of its irrigation water from the Jensen Unit. The other 10 percent, or 400 acres, is full-service land that receives all of its irrigation water from the Jensen Unit. The full-service lands are in small tracts interspersed among the supplemental- 


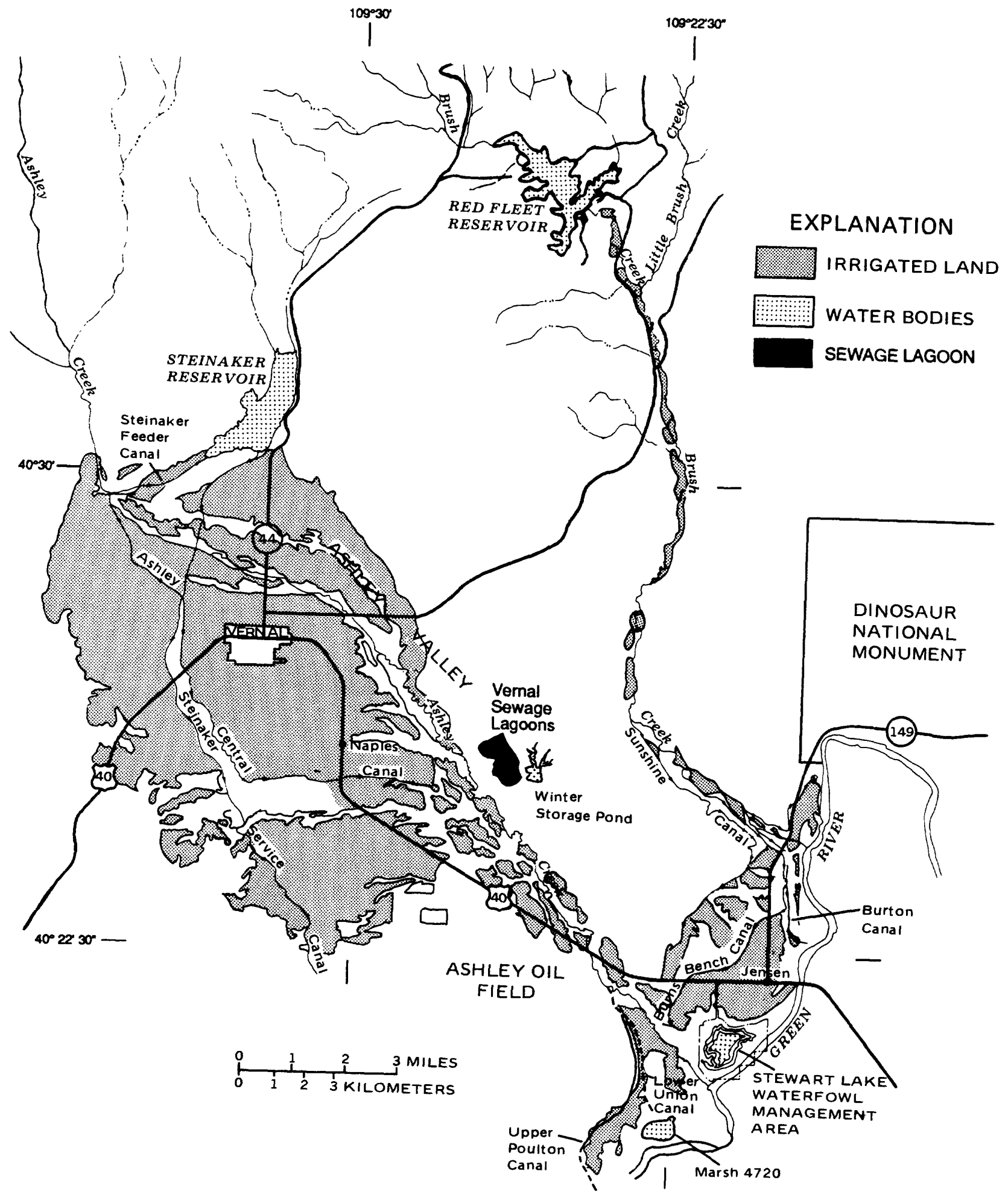

Figure 5. Locations of reservoirs and selected hydrologic features near Vernal and Jensen, Utah. 
service lands. Land that is presently irrigated has been irrigated on a sustained basis for more than 60 years.

Subsurface drains were installed by the USBOR from 1974 to 1981 . Although there are about 4,000 acres of irrigated land in the Jensen area, the federally sponsored drainage system involves only about 750 acres, almost all of which is supplemental-service irrigation. The land that required drains occupies topographic lowlands near the northern edge of Stewart Lake WMA and was either deficient in drainage or was expected to become deficient during the life of the project. These lands are subject to flooding by surface water and subsurface inflow of ground water from lands higher on the bench, have a relatively flat ground surface, and have no well-developed outlet channels for surface runoff and subsurface drainage. They do, however, have good permeability so that artificial drainage is feasible.

Five ground-water drains (J1a and J1-J4), consisting of 8- to 18-in. diameter concrete pipe with bell and spigot unions, discharge to the lake (fig. 6). The unions are designed to provide about a 1/8-in. gap that allows water to infiltrate into the pipe through the 4-in. gravel pack surrounding it. The drains are at a depth of 8 to $10 \mathrm{ft}$ beneath the surface of the agricultural land north of the lake. Manholes every $1,200 \mathrm{ft}$ provide access to the pipe for cleaning. The total discharge from these drains typically averages about $7 \mathrm{ft}^{3} / \mathrm{s}$ during summer and $3 \mathrm{ft}^{3} / \mathrm{s}$ during winter. The irrigation season is typically May through September with drainage reaching the lake throughout this period. Outflow from the lake enters the Green River.

\section{Ashley Creek and Marsh 4720}

\section{Location and Wildlife Use}

Ashley Creek drains Ashley Valley near Vernal, Utah, and discharges to the Green River (fig. 5). The valley contains about 28,000 acres of irrigated agricultural land and a large percentage of the population of Uinta County. The principal source of water for the valley is streamflow from the Ashley Creek drainage basin and includes a small transbasin diversion piped from springs near the headwater of Ashley Creek. Domestic and industrial liquid wastes in Ashley Valley are collected by a sewer system. Prior to 1981 treated wastewater was released to Ashley Creek, but following completion of a sewage-lagoon system (on the hills east of Ashley Creek), no surface water has been discharged directly to the creek.

Wetlands adjacent to Ashley Creek in the meander areas near U.S. Highway 40 provide considerable wildlife habitat, and a marsh (called marsh 4720 in this report) is along the Green River $1 \mathrm{mi}$ south of Stewart Lake WMA. The marsh is leased by the Utah Department of Natural Resources and managed as a waterfowl area. It receives irrigation tailwater but does not receive irrigation return flows by way of subsurface drains. Waterfowl using the Winter Storage Pond associated with the Vernal sewage lagoons $1.5 \mathrm{mi}$ east of the Vernal airport near Ashley Creek (fig. 5) have been estimated in the hundreds by USFWS personnel during this study. There has been no quantification of wildlife use of lower Ashley Creek, and the only observations of wildlife use of marsh 4720 are discussed later in this report.

\section{Hydrogeology and Soils}

Ashley Valley is unique in the northern Uinta Basin because it is a relatively isolated hydrologic unit. The alluvial plain has an area of about 35,000 acres and is almost entirely surrounded by older rocks, mainly from the Cretaceous Period. The aquifer underlying the plain consists of fine to very coarse unconsolidated deposits of boulders and other erosional debris believed to be mostly outwash of glacial origin (Hood, 1977, p. 6). The deposits were laid down on a surface eroded mostly in the Mancos Shale; this is the dominant feature of the geology affecting the area.

Hood $(1977$, p. 8) reported that subsurface inflow to Ashley Creek may come from consolidated rocks that abut the valley fill. Little, if any, water rises through the underlying Mancos Shale, but 


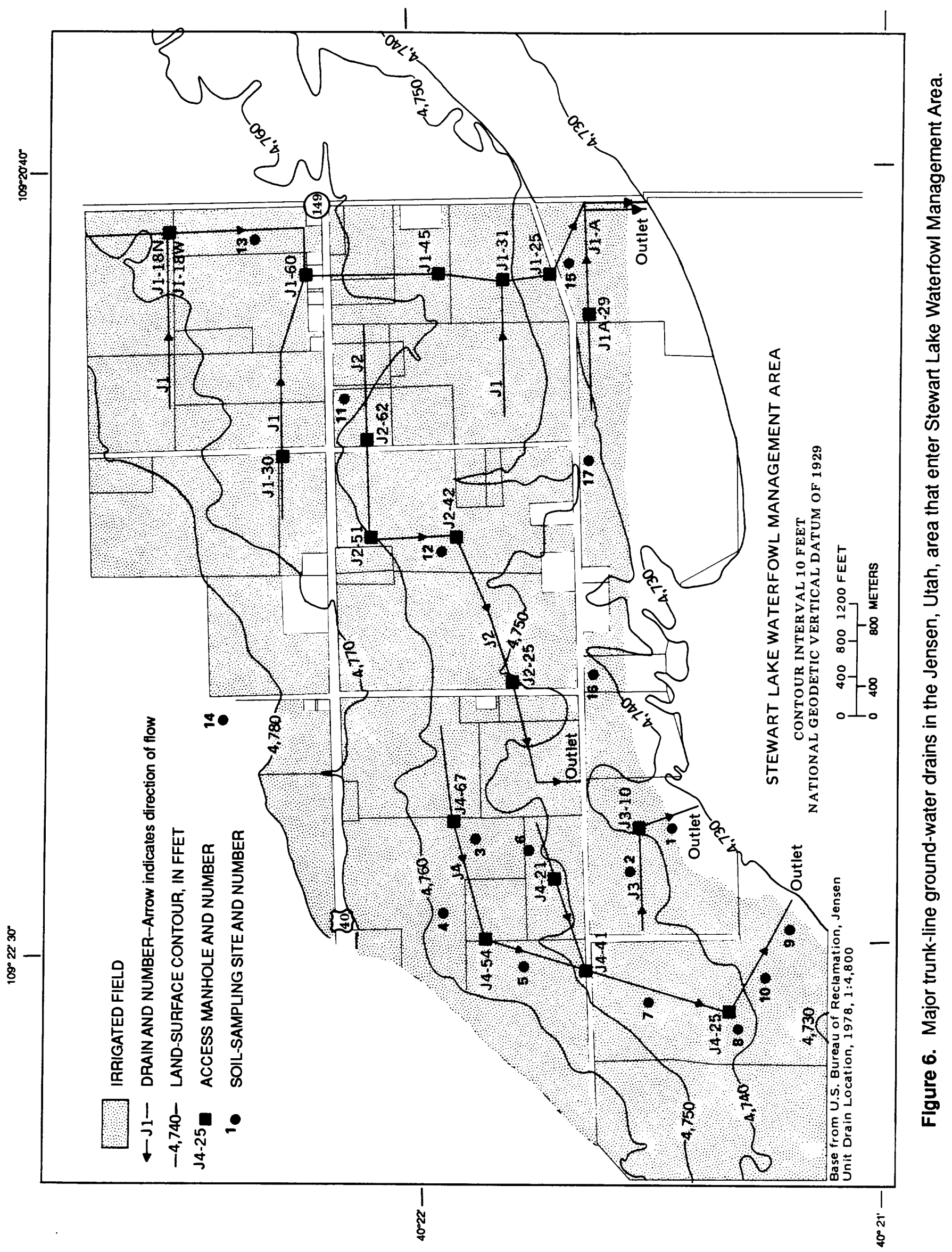


some inflow comes from the nearby Glen Canyon Sandstone of Jurassic age and Dakota Sandstone and Mesaverde Group of Cretaceous age. The inflow from the consolidated rocks was estimated to be less than that from underflow beneath Ashley Creek. Permeability, as determined by pump tests on 24 deep test holes, was 6 in. per hour for the fine alluvium and $100 \mathrm{in}$. per hour for the gravel aquifer. On the basis of soil textures in the area, an estimated 15-20 percent of the water applied to the surface goes to deep infiltration (U.S. Bureau of Reclamation, 1977, p. 37).

Soils range from about 2 to $20 \mathrm{ft}$ in depth and are composed of alluvial clays, silts, sands, and loams. Below the soil layer is 4 to $45 \mathrm{ft}$ of cobbles and sand transported from upstream areas of Ashley Creek. The bedrock is Mancos Shale, several thousand $\mathrm{ft}$ in thickness. While there are nineteen soil types in the area described by Strahorn and others (1924), the Billings Series is of greatest interest in this report because it is derived from the weathering of Mancos Shale.

\section{Irrigation and Drainage}

Prior to 1963, there was little storage of surface water in Ashley Creek drainage basin. Irrigation water was plentiful only in the early summer, and fields were heavily irrigated at that time (Hood, 1977). The USBOR, with the Vernal Unit of the Central Utah Project, constructed Steinaker Reservoir north of Vernal between 1961 and 1963 to retain runoff. During the spring, runoff from the Uinta Mountains is diverted from Ashley Creek by the Steinaker Feeder Canal for storage in Steinaker Reservoir. The reservoir has a capacity of 37,200 acre-ft and covers 820 acres. The Steinaker Service Canal and the Rock Point Canal convey water from Steinaker Reservoir to Ashley Valley for use in irrigation. Additional conveyance of Ashley Creek water is provided by the Ashley Upper Canal and the Highline Canal near the western edge of Ashley Valley, and the Ashley Central Canal that crosses the valley just south of Naples (fig. 7).

Subsequent to the completion of Steinaker Reservoir, the USBOR determined there were 14,041 acres of productive, irrigable land in the Vernal area, with 20 percent in need of drainage (U.S. Bureau of Reclamation, 1977, p. 6). The drainage problems were the result of a high water table caused by excessive application of irrigation water, canal seepage, and diversions for stock water during the non-irrigation season. Also contributing were two geologic conditions: an overloading of the cobble aquifer due to a decrease in slope and thickness of the aquifer generally from west to east, and a cemented barrier formed by the precipitation of calcium carbonate in the gravel and boulders along the escarpment adjacent to the entrenched river bottoms. This barrier has the effect of a dike restricting the natural outlet that removes surplus ground water from the area. Between 1970 and 1981 the USBOR installed about $19 \mathrm{mi}$ of subsurface drains in the Vernal area to overcome this barrier (fig. 7). The drains collect subsurface water and discharge it to irrigation canals such as the Ashley Central or to a series of eight natural channels that flow into Ashley Creek. Ownership and maintenance of the drains remains with the Uintah Water Conservancy District.

During summer months, most of the flow in Ashley Creek downstream of U.S. Highway 40 is irrigation tailwater, shallow ground water, and 2,400 acre-ft of subsurface water removed as a byproduct from the Ashley Oil Field (Goode and Feltis, 1962). Marsh 4720 receives surface inflow from the Lower Union Canal, a surface channel that provides irrigation water to farms in the area. The water is diverted from Ashley Creek near U.S. Highway 40 and joins with formation water flowing from Ashley Oil Field.

\section{Ouray National Wildlife Refuge Area}

\section{Location and Wildlife Use}

Ouray NWR is adjacent to the Green River $30 \mathrm{mi}$ southwest of Vernal near the town of Ouray, Utah (fig. 8). It has an area of 11,827 acres that includes 2,700 acres of leased land in the Uintah and Ouray Indian Reservation. The refuge was established in 1960 as part of the mitigation for construction of Flaming Gorge Reservoir and is managed by the USFWS primarily as waterfowl 


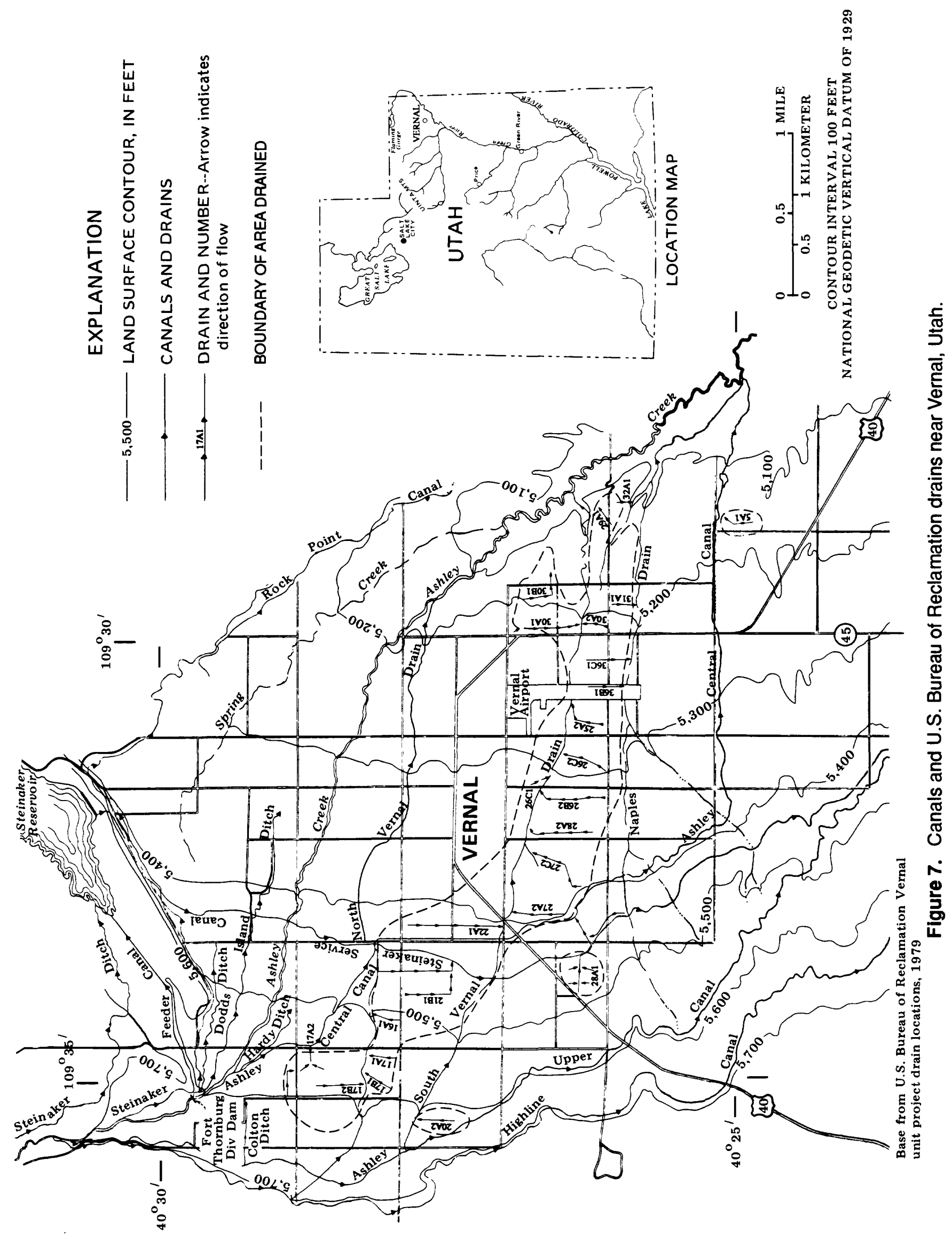




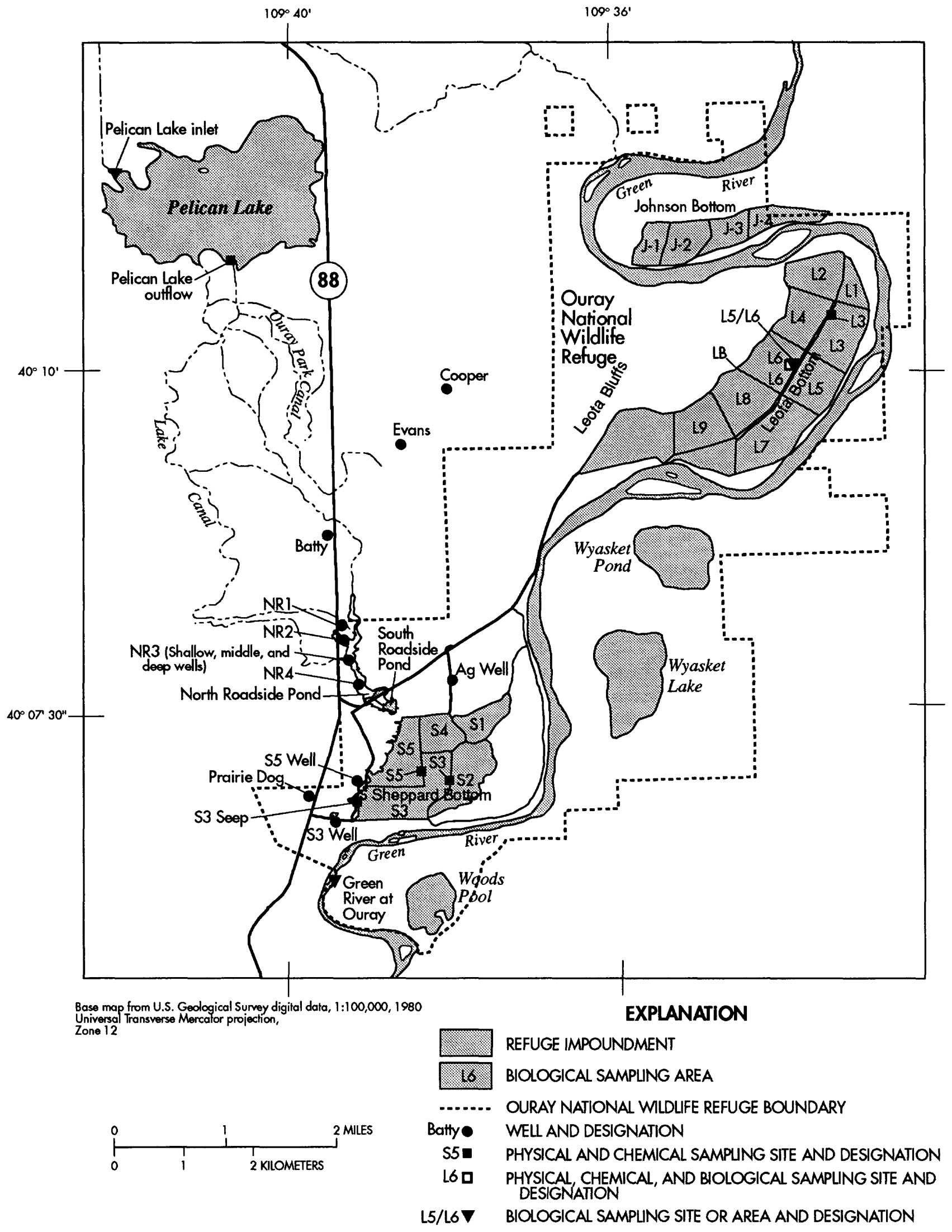

Figure 8. Selected data-collection sites at Ouray National Wildlife Refuge and Pelican Lake. 
habitat. The refuge provides migration rest and nesting areas for over 200 species of waterbirds and raptors, with bird-use days exceeding $1,850,000$ annually, primarily by 14 species of ducks. The area also is used by migrating whooping cranes (Grus americana), wintering peregrine falcons (Falco peregrinus), and bald eagles (Heliaeetus leucocephalas), and as yearlong habitat for four species of endangered fish (Colorado squawfish, humpback chub, bonytail chub, razorback sucker). The refuge is in a desert environment and relies on flooding or pumping from the Green River or irrigation water from the Uinta Mountains for its water supply.

\section{Hydrogeology and Soils}

Quaternary gravels and recent alluvial deposits characterize the surficial geology near Ouray NWR. Fluvial and lake deposits of the Uinta Formation and fluvial sandstone and mudstone of the Duchesne River Formation of Tertiary age make up most of the upland areas in the reach of the Green River between Stewart Lake WMA and Ouray NWR. Pelican Lake is in a large, shallow wind-scoured depression about $7 \mathrm{mi}$ north of the town of Ouray. South and southeast of Pelican Lake is an area of low ridges and mounds of loose sand that forms a typical dune topography.

Near the surface the region is underlain by two sedimentary formations of Tertiary age. The larger plain is underlain by the brick-red and variegated colored clays, mudstones, tuffaceous shales, and bentonite clays of the Uinta Formation. These fluvial sediments strike east and dip slightly north beneath the plain in the opposite direction to the slope of the plain. The upper plain is underlain by the younger Duchesne River Formation, which consists predominantly of sandstones and siltstones. These more resistant beds form the upper two-thirds of the escarpment near Pelican Lake (Marsell, 1964).

Ground water in the Ouray area occurs in four aquifers. The upper, or alluvial aquifer is present in valley-fill deposits near the Green River. A second, unnamed aquifer is present at the junction of the lower beds of the Duchesne River Formation and the uppermost sandy beds of the Uinta Formation. Sandstones in these two formations mostly contain water under artesian pressure, and they have small permeabilities (Hood, 1976, p. 34). The bird's nest aquifer, an informally named zone, is present near the interface of the Uinta and Green River Formations. It lies at a depth of between 500 and 1,200 ft and has a thickness ranging from 90 to $205 \mathrm{ft}$ (Holmes and Kimball, 1987, p. 21). The deepest consolidated-rock aquifer, known as the Douglas Creek aquifer, underlies most of the southeastern Uinta Basin and extends partly into the Ouray area.

The thickness of the alluvial fill in the Ouray area is not known, but Holmes and Kimball (1987, p. 7) indicate the average thickness of the alluvial fill in the White River drainage 2 mi down the Green River from Ouray is $30 \mathrm{ft}$. Recharge to the alluvial aquifer is primarily by streamflow or canal seepage, with leakage from the deep aquifer only providing an estimated 7 percent of the recharge (Holmes and Kimball, 1987, p. 7). The average velocity of water moving through the alluvial aquifer is about $0.4 \mathrm{ft} / \mathrm{d}$ (foot per day) (Holmes and Kimball, 1987, p. 8).

The Douglas Creek aquifer consists of beds of sandstone and limestone of the Douglas Creek Member of the Green River Formation and some sandstone beds of the Wasatch Formation. At its northern extent near Ouray, the aquifer may be about $500 \mathrm{ft}$ thick and is overlain by relatively impermeable marlstone, siltstone, and oil-shale beds that inhibit vertical movement of water. The aquifer discharges to the White and Green Rivers and to major tributaries where the potentiometric surface of the aquifer is above the bottoms of the valleys (Holmes and Kimball, 1987, p. 34).

The soil over most of the area consists of a veneer of fine sandy and silty loam brought in and deposited by wind and sheet floods from the surrounding region. Soils near Ouray NWR are developed on alluvium similar to those near Jensen, are well drained, and surface-water runoff from them is rapid; however, the calciorthid soils near Ouray NWR are characterized as being thick and moderately to strongly alkaline. Surface layers are reddish-yellow and consist of silt and loam, and calciumcarbonate layers occur between depths of 10 and $40 \mathrm{in}$. 


\section{Irrigation and Drainage}

Areas northwest of Ouray NWR are irrigated extensively using water from Pelican Lake delivered by the Ouray Park Irrigation Company. No irrigation water is known to be supplied by USBOR facilities (Leon Meldron, U.S. Bureau of Reclamation, written commun., 1987). Much of the return flow typically enters the Green River south of Ouray NWR through the Duchesne River; however, water from about 1,400 acres drains toward the Ouray NWR. Some of this water discharges through seepage and surface runoff to ponds on the western border of the refuge. Water use within the NWR is estimated at 3,000 to 8,000 acre-ft annually, with about 75 percent from the Green River, 20 percent from Pelican Lake (by the Ouray Park Irrigation Company), and the balance from seepage and runoff (table 1).

Irrigation water from Pelican Lake enters the refuge through a system of canals and underground pipe and is used to irrigate grain grown for waterfowl food. Some of the return flow from this irrigation may enter ponds in the Sheppard Bottom area. Irrigation water from the Lake Canal also enters the draw north of the Roadside Ponds and flows through these ponds into Sheppard Pond S5. Prior to 1989, water could flow into ponds S3 and S4 where it mixed with water pumped from the Green River; however, in 1989, the dikes were modified to eliminate surface discharge from S5. The Johnson Bottom, Leota Bottom, and Wyasket areas receive water almost exclusively from the Green River. The refuge maintains about 2,500 acres in shallow, fresh-water marsh habitat through a series of dikes and gravity flow of water from the Green River. An additional 6,000 acres is unregulated riverbottom lands.

\section{Pariette Wetlands}

\section{Location and Wildlife Use}

Pariette Wetlands is a USBLM wetland complex of 9,000 acres on Pariette Draw (fig. 9) about $35 \mathrm{mi}$ southwest of Vernal, Utah. It is one of two such wetlands in the United States established by the USBLM to provide managed waterfowl habitat where none previously existed. It drains an area of about $300 \mathrm{mi}^{2}$ adjacent to the Green River. The complex is formed by a series of dikes and ponds on Pariette Draw and is the marsh component of a larger USBLM area of 277,755 acres called the Myton Wildlife Habitat Area.

A major management objective of the wetlands is to provide habitat capable of producing 10,000 ducks and 100 geese annually. About 1,100 ducks and 50 geese were produced in 1989. The area also provides nesting and feeding areas for a variety of colonial birds, raptors, upland birds, and

Table 1. Annual water use and supply for Ouray National Wildlife Refuge, 1986-90

[In acre-feet per year. Total use consists of evaporation, seepage outflow, and discharge to other ponds or to the Green River]

\begin{tabular}{ccccc}
\hline \multirow{2}{*}{$\begin{array}{c}\text { Calendar } \\
\text { year }\end{array}$} & $\begin{array}{l}\text { Total } \\
\text { use }\end{array}$ & & \multicolumn{3}{c}{ Source of supply } \\
\cline { 3 - 5 } & Green River & Pelican Lake & Seepage and runoff \\
\hline 1986 & 3,018 & 2,308 & 600 & 110 \\
1987 & 3,877 & 2,832 & 875 & 170 \\
1988 & 6,688 & 5,396 & 870 & 422 \\
1989 & 3,953 & 3,500 & 169 & 284 \\
1990 & 7,833 & 7,321 & 375 & 137 \\
\hline
\end{tabular}


furbearers and also is used seasonally by bald eagles and peregrine falcons. A total of 39 eagles were counted near Gadwall Pond during the spring of 1988. Endangered fish have been observed near the confluence of Pariette Draw and the Green River.

\section{Hydrogeology and Soils}

Pariette Wetlands is on the Uinta Formation of Tertiary age, which consists of variegated shale with interbedded sandstone. The formation is regarded by Rosenfeld and Beath (1964) as seleniferous in areas.

Ground-water conditions are similar to those near Ouray NWR. An alluvial-fill aquifer contains slightly saline ground water. The bird's nest aquifer lies near the contact of the Uinta and Duchesne River Formations, and the consolidated-rock Douglas Creek aquifer lies at considerable depth beneath.

Quaternary gravels and alluvial deposits provide the surficial material for the five soil types in the area: (1) soils of the Naples and Billings series that were formed on recent alluvium and are the most arable in the area, although some of the soils have an accumulation of salts or alkali; (2) soils of the Mesa or Avalon series that formed on benches and mesas with sloping relief; (3) shallow soils of the Ashley and Myton series that formed on recent alluvium, generally in the floodplains of streams; (4) Shavano, Pariette, and Chipeta soils that are shallow to moderately deep and formed over bedrock, often Mancos Shale; and (5) soils represented by rough lands with very little soil (Wilson and others, 1959).

\section{Irrigation and Drainage}

Water diverted from the Duchesne River provides irrigation in Pleasant Valley upstream of Pariette Wetlands. The average annual flow in Pariette Draw (1975 to 1984) measured at the gaging station 1-mi upstream of Pariette Wetlands was 20,000 acre-ft. The wetland complex has about 12 small ponds and interconnecting canals that are used for irrigation and wildlife habitat. These are managed from April to October to control vegetation and provide for a small quantity of crop irrigation. The average discharge of Pariette Draw to the Green River for the period of record (1975 to 1984) was $22.8 \mathrm{ft}^{3} / \mathrm{s}$. Typically, 60 percent of the total annual flow of 16,520 acre-ft occurs from August through November.

There is potential for expansion of the complex if it is selected as a wildlife mitigation area for the USBOR Uinta Stage I Salinity Control Unit. This would require an additional 2,000 acre-ft of water. Several ground-water drains currently exist in Pleasant Valley. Although more drains were originally planned, none were constructed.

\section{Previous Studies of Selenium in Soils}

Selenium in soils in the San Joaquin Valley in California has been studied extensively during the past decade. Prior to these studies, selenium had been investigated in the west by Trelease and Beath (1949), Byers (1936), and Byers and others (1938). The early studies followed instances of selenium poisoning of livestock by forage crops in Nebraska, Wyoming, and South Dakota. An extensive treatise on selenium investigations in the West was done by Trelease and Beath (1949). The authors concluded (p. 106): "The maximum quantity of selenium found in the examination of several thousand soil samples was less than $100 \mathrm{ppm}$, and fifty percent of the seleniferous soils that were analyzed contained less than $2 \mathrm{ppm}$." Selenium species have highly variable solubility; therefore, it is beneficial to distinguish between elemental selenium, selenite, selenate, and organic selenium in chemical analyses of soils.

The differences in rates of biological uptake of the various forms of selenium by plants make prediction of selenium availability difficult, particularly from total soil selenium data. Elemental selenium, selenite, and selenium associated with iron oxide are very insoluble in most natural chemical 


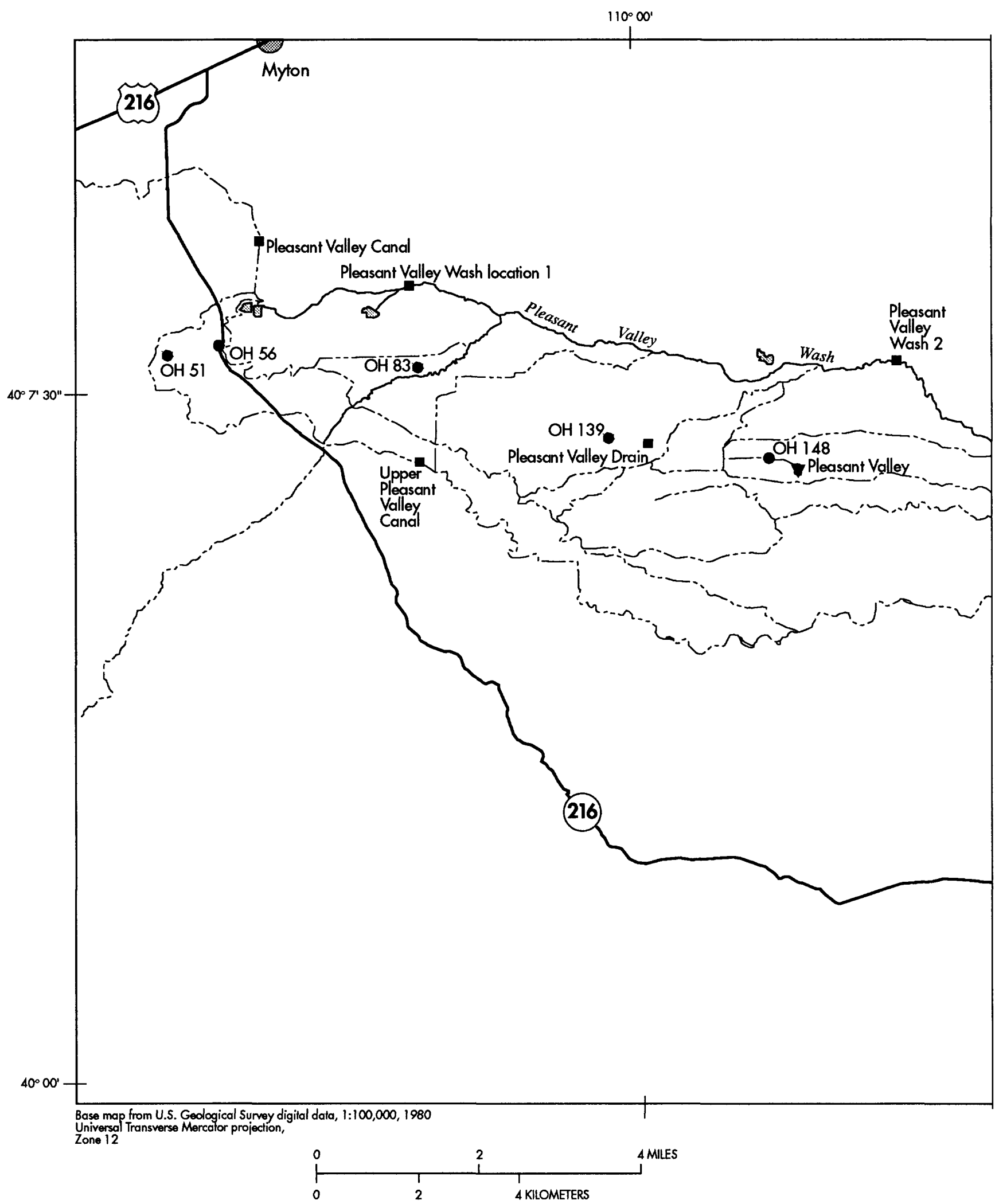

Figure 9. Locations of wells and surface-water and biological sampling sites 


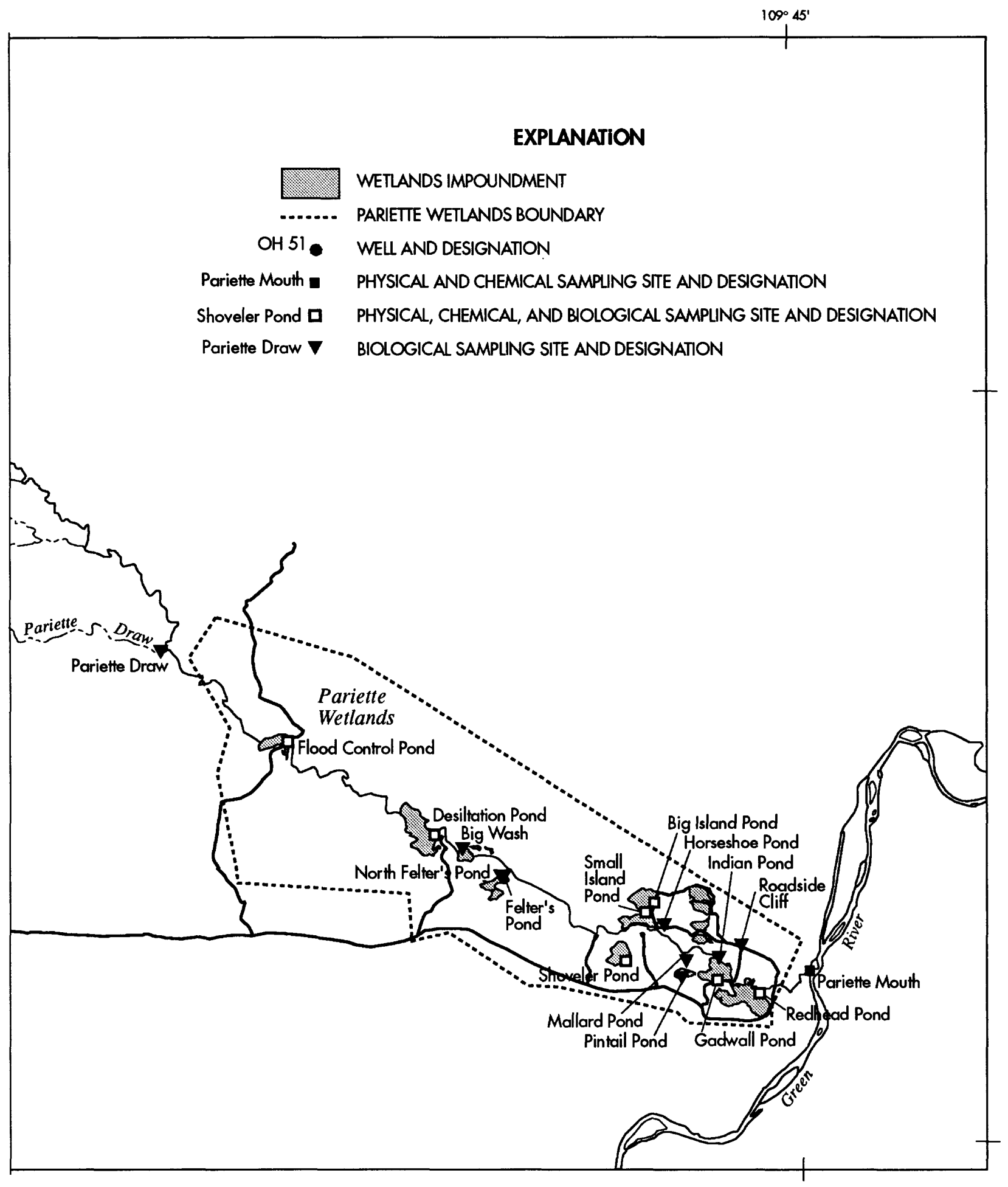

and areas in Pleasant Valley and Pariette Wetlands south of Myton, Utah. 
environments. Selenate and some organic forms of selenium are very soluble and available for plant uptake.

Thousands of selenium-indicator plants, primarily Astragalus, were tested, and maps depicting selenium concentrations in indicator plants and geologic formations associated with potentially toxic seleniferous plants were prepared by Trelease and Beath (1949). The Green and Colorado River Basins were identified as areas in which numerous plants were found that had selenium concentrations ranging from 50 to 8,512 ppm (Trelease and Beath, 1949, p. 83). Some of the larger concentrations in both plants and soil were found in Utah; however, Trelease and Beath (1949) did not cite any documented cases of selenium poisoning of livestock in Utah.

Interest in soil selenium and toxicity research diminished after 1950 . The total number of soil samples analyzed by Trelease, Beath, and others prior to 1950 has probably not been equalled since; however, selenium as an essential trace element and diseases related to selenium deficiency became subjects of extensive worldwide research over the past two decades.

The distribution of selenium in soils of the San Joaquin Valley in California was described by Tidball and others (1986), and leaching studies were done by Fujii and others (1988). The results of these studies were summarized by Gilliom $(1989, \mathrm{p}$. 11). The conclusion of these authors was not significantly different from that of Trelease and Beath (1949): there is no correlation between location of soils and ground water with large selenium concentrations. A greater understanding of chemical speciation, selenite soil adsorption, reduction and possible precipitation with deeper ground-water migration, and concentration by evapotranspiration are presented in Gilliom (1989); however, the authors indicate that reliable models are not available to predict selenium leaching or bioaccumulation rates.

There are large concentrations of salts in Mancos Shale and soils derived from it. Laronne (1977a, p. 70) reported terraces of Mancos Shale contained 0.3 to 1.7 percent soluble salts. The dominant mineral is gypsum. Associated with the gypsum are often significant selenium concentrations that have replaced sulfur. Williams and Byers (1935) reported that three samples of Mancos Shale from western Colorado contained total selenium concentrations of 2,000 to 6,000 ppb. Because selenate behaves like sulfate in soils and is not as strongly adsorbed as selenite by soil minerals such as goethite (Neal and Sposito, 1989, p. 73), selenate may be readily leached by water.

\section{COLLECTION AND ANALYSIS OF DATA}

\section{Hydrologic Sampling Sites}

Many of the sampling sites near Stewart Lake WMA and Ouray NWR used in the reconnaissance study (Stephens and others, 1988a, p. 25) were also used in the detailed study. In addition, many new sites were established and sampled as part of a specific project in the detailed study. A listing and maps showing all surface- and ground-water sites used in this study appears in Peltz and Waddell (1992).

Several observation wells installed by the USBOR to depths that did not exceed $20 \mathrm{ft}$ were sampled in the Jensen and Pleasant Valley areas. Generally, these wells were lined with polyvinyl chloride (PVC) pipe casing and were slotted throughout the depth of the well. USBOR wells sampled in the Pleasant Valley area typically were cased with galvanized steel and randomly perforated throughout the depth. The Batty and Cooper wells in the Ouray area were steel cased and had been, or currently were being, used for domestic purposes. All other monitoring wells were installed by the USGS, with depths ranging from 2.2 to $65 \mathrm{ft}$. These wells were auger-drilled and sand-packed using sand with a $20-40$ mesh grain size $(0.05$ to $0.1 \mathrm{in}$.) in the area of $0.05 \mathrm{in}$. slotted casing. Each annulus was sealed using bentonite with a measured selenium content less than the detection limit of $1 \mu \mathrm{g} / \mathrm{g}$, and the well was finished at land surface with concrete. All wells were cased with 1 in.-diameter PVC 
pipe with glued connections, or 2-in. diameter PVC pipe with threaded connections. Removable PVC caps were used on all wells.

\section{Collection and Analysis of Water Samples}

Water samples were collected from wells using either a dedicated WaTerra ${ }^{1}$ inertial pump with Delrin foot valve and high-density polyethylene tubing, or a Brainard-Kilman 1.7-in. positivedisplacement piston pump that discharged to the surface through PVC pipe. Each well was pumped dry, or water equivalent to two casings in volume was removed, generally one day prior to collection of a water sample. Virtually all wells recovered within one day.

The collection of samples was done using procedures given by the U.S. Geological Survey (1977). Grab samples of water were collected from most surface-water sites because the flow was small and well-mixed; however, samples collected from Ashley Creek at U.S. Highway 40 were collected using equal-width, depth-integrated methods and a DH-48TM sampler (U.S. Geological Survey, 1977, p. 3-20). Field measurements of conductivity and $\mathrm{pH}$ were made using meters that were calibrated prior to use with at least two standards. Water samples requiring filtration were processed in the field using $0.45 \mu \mathrm{m}$ filters and a plastic filtration unit. When acid was used to stabilize samples for tracemetal analyses, one $\mathrm{ml}$ of concentrated nitric acid was added per $250 \mathrm{ml}$ of sample. This addition resulted in a final $\mathrm{pH}$ of less than 2 , which was verified by direct measurement on several occasions. Water samples collected for radiochemical analysis were preserved with hydrochloric acid to a pH less than 2 , and stable-isotope samples were preserved with tablets of mercuric chloride.

A field or pump blank usually was collected during each field trip. The field blank consisted of deionized water filtered and stabilized using nitric acid. The pump blank consisted of deionized water pumped through a well-sampling pump, filtered, and stabilized using nitric acid. The blank sample was always analyzed for selenium, and on three occasions, for selected trace elements. Concentrations of all trace elements examined in the blanks except boron, lead, and selenium never exceeded the lower reporting level. Boron concentrations in the blanks ranged from 20 to $50 \mu \mathrm{g} / \mathrm{L}$, and lead on one occasion was $6 \mu \mathrm{g} / \mathrm{L}$. On one occasion a field blank for selenium was $1 \mu \mathrm{g} / \mathrm{L}$, and on one occasion the pump blank was $2 \mu \mathrm{g} / \mathrm{L}$. The source of the minor contamination in the field blanks is not known, although incomplete washing of the pump likely caused the contamination of the pump blank.

Analytical determinations of common ions and trace elements in water were made by the USGS Water Resources Division laboratory in Arvada, Colorado, using procedures of Fishman and Friedman (1985). Radiochemical analyses were done by a private laboratory under contract to the USGS using procedures given by Thatcher and others (1977). Tritium concentrations reported in $\mathrm{pCi} / \mathrm{L}$ were converted to tritium units by division by the factor 3.22 (Thatcher and others, 1977, p. 66). The stable-oxygen isotopic composition was determined by modification of the carbon dioxide equilibration method of Epstein and Mayeda (1953). The stable hydrogen isotopic composition was determined by analyzing hydrogen quantitatively extracted from water (Kendall and Coplen, 1985). The constituents of interest and the smallest reporting levels are given in table 2.

Selenium was not detected in any water samples from the drains at Stewart Lake that were analyzed by the Utah Department of Health laboratory for the USBOR between 1978 and 1987. Samples from these drains analyzed by the USGS during the current study contained as much selenium as $140 \mu \mathrm{g} / \mathrm{L}$. Officials from the USBOR met with Utah Department of Health officials in February 1987 to evaluate the methodology used to determine selenium concentrations. The method used at that time involved generation of selenium hydride using hydrochloric acid followed by determination using atomic absorption spectrometry. No sample oxidation-reduction digestion procedure was employed prior to analysis. In the absence of an oxidation-reduction digestion, the hy-

1 The use of trade names in this report is for identification purposes only and does not constitute endorsement by the USGS. 
Table 2. Reporting levels for constituents determined in water and bottom sediment

$\left[{ }^{\circ} \mathrm{C}\right.$, degrees Celsius; $\mathrm{mg} / \mathrm{L}$, milligrams per liter; $\mu \mathrm{g} / \mathrm{L}$, micrograms per liter; $\mathrm{pCi} / \mathrm{L}$, picocuries per liter; $\mu \mathrm{g} / \mathrm{g}$, micrograms per gram; SMOW, Standard Mean Ocean Water; permil, parts per thousand; -, not analyzed]

\begin{tabular}{|c|c|c|c|}
\hline \multirow[b]{2}{*}{ Constituent } & \multicolumn{3}{|c|}{ Analytical reporting level } \\
\hline & \multicolumn{2}{|c|}{ Water } & $\begin{array}{c}\text { Bottom } \\
\text { sediment }\end{array}$ \\
\hline Alkalinity & 0.1 & $\mathrm{mg} / \mathrm{L}$ & - \\
\hline Calcium & .1 & $\mathrm{mg} / \mathrm{L}$ & - \\
\hline Chloride & .1 & $\mathrm{mg} / \mathrm{L}$ & - \\
\hline Fluoride & .1 & $\mathrm{mg} / \mathrm{L}$ & - \\
\hline Magnesium & .1 & $\mathrm{mg} / \mathrm{L}$ & - \\
\hline Nitrite plus nitrate & .1 & $\mathrm{mg} / \mathrm{L}$ & - \\
\hline Silica & .1 & $\mathrm{mg} / \mathrm{L}$ & - \\
\hline Sodium & .1 & $\mathrm{mg} / \mathrm{L}$ & - \\
\hline Sulfate & 1 & $\mathrm{mg} / \mathrm{L}$ & - \\
\hline Solids, volatile on ignition & - & & $\mu \mathrm{g} / \mathrm{g}$ \\
\hline Solids, total residue at $180^{\circ} \mathrm{C}$ & 1 & $\mathrm{mg} / \mathrm{L}$ & - \\
\hline Arsenic & 1 & $\mu \mathrm{g} / \mathrm{L}$ & $\mu \mathrm{g} / \mathrm{g}$ \\
\hline Barium & 100 & $\mu \mathrm{g} / \mathrm{L}$ & $\mu \mathrm{g} / \mathrm{g}$ \\
\hline Boron & 10 & $\mu \mathrm{g} / \mathrm{L}$ & $\mu \mathrm{g} / \mathrm{g}$ \\
\hline Cadmium & 1 & $\mu \mathrm{g} / \mathrm{L}$ & $\mu \mathrm{g} / \mathrm{g}$ \\
\hline Carbon, inorganic & - & & $\mu \mathrm{g} / \mathrm{g}$ \\
\hline Carbon, inorganic plus organic & - & & $\mu \mathrm{g} / \mathrm{g}$ \\
\hline Chromium & 10 & $\mu \mathrm{g} / \mathrm{L}$ & - \\
\hline Copper & 10 & $\mu \mathrm{g} / \mathrm{L}$ & $\mu \mathrm{g} / \mathrm{g}$ \\
\hline Lead & 1 & $\mu \mathrm{g} / \mathrm{L}$ & $\mu \mathrm{g} / \mathrm{g}$ \\
\hline Mercury & .1 & $\mu \mathrm{g} / \mathrm{L}$ & $.01 \mu \mathrm{g} / \mathrm{g}$ \\
\hline Molybdenum & 1 & $\mu \mathrm{g} / \mathrm{L}$ & $.1 \mu \mathrm{g} / \mathrm{g}$ \\
\hline Nickel & 1 & $\mu \mathrm{g} / \mathrm{L}$ & - \\
\hline Selenium & 1 & $\mu \mathrm{g} / \mathrm{L}$ & $\mu \mathrm{g} / \mathrm{g}$ \\
\hline Silver & 1 & $\mu \mathrm{g} / \mathrm{L}$ & - \\
\hline Vanadium & 1 & $\mu \mathrm{g} / \mathrm{L}$ & - \\
\hline Zinc & 10 & $\mu \mathrm{g} / \mathrm{L}$ & $\mu \mathrm{g} / \mathrm{g}$ \\
\hline Gross alpha (as natural uranium) & .4 & $\mu \mathrm{g} / \mathrm{L}$ & - \\
\hline Gross beta (as Cesium 137) & .4 & $\mathrm{pCi} / \mathrm{L}$ & - \\
\hline $\begin{array}{c}\text { Gross beta (as Strontium 90/ } \\
\text { Ytterbium 90) }\end{array}$ & .4 & $\mathrm{pCi} / \mathrm{L}$ & - \\
\hline Radium 226 & .1 & $\mathrm{pCi} / \mathrm{L}$ & - \\
\hline Uranium, natural & .4 & $\mu \mathrm{g} / \mathrm{L}$ & - \\
\hline Oxygen-18/Oxygen-16 relative to SMOW & & permil & - \\
\hline Deuterium/Protium relative to SMOW & 1.5 & permil & - \\
\hline
\end{tabular}


dride method determines selenium present only in the +4 oxidation state as selenite (Presser and Ohlendorf, 1987). Consequently, analyses of selenium done by the State laboratory represent only the selenite part present in the drainwater, a very small part of the total selenium. The procedure used by the USGS uses the hydride-generation methodology, but sample preparation employs an oxidation of the sample using potassium permanganate in a hot acid solution, followed by reduction of the selenate to selenite using hydrochloric acid. A final reduction to selenium hydride is done using stannous chloride in hydrochloric acid.

\section{Criteria and Standards Used to Evaluate Elements in Water}

Earlier reconnaissance of water quality in the middle Green River basin (Stephens and others, 1988a) suggested hazards to human health, fish, wildlife, and water uses that involved selenium, uranium, boron, nitrate, and zinc, in order of severity. Subsequent study of the water quality during 1988-89 emphasized selenium with limited analyses for uranium and boron.

\section{Selenium}

In April 1988, the State of Utah revised its water-quality criteria and standards. The standard for dissolved selenium in water to protect aquatic wildlife was reduced from $50 \mu \mathrm{g} / \mathrm{L}$ to $5 \mu \mathrm{g} / \mathrm{L}$. This value was qualified to be a 4-day average, not to exceed $20 \mu \mathrm{g} / \mathrm{L}$ for more than 1 hour during a 3-year period (Utah Department of Health, 1988). The selenium standard for water used as a domestic source was left unchanged at $10 \mu \mathrm{g} / \mathrm{L}$. Stewart Lake, Ouray NWR, downstream parts of Ashley and Brush Creeks, Pariette Draw, and the Green River are protected as Utah class 3B (aquatic wildlife) and class 4 (agricultural) water; therefore, the Utah standard of $5 \mu \mathrm{g} / \mathrm{L}$ for dissolved selenium is used throughout this report.

\section{Uranium and Alpha Radiation}

Naturally occurring uranium in the oxidation series from $\mathrm{UO}_{2}$ to $\mathrm{U}_{3} \mathrm{O}$ is generally not very toxic to animals when ingested, whereas the $\mathrm{UO}_{3}$ radical, present in such minerals as becquerelite, is highly toxic when ingested (Gough and others, 1979, p. 54). In a stream receiving uranium-mill waste, Mitchum and Moore (1966) reported that uranium concentrations of $5 \mu \mathrm{g} / \mathrm{L}$ did not appear harmful to most fish, but that concentrations of 60 to $2,000 \mu \mathrm{g} / \mathrm{L}$ were believed to be toxic to trout. The National Academy of Sciences (1983) recommends a uranium limit of $35 \mu \mathrm{g} / \mathrm{L}$ in water for human consumption. The State of Utah does not have an applicable standard for elemental uranium in water; however, gross alpha radiation is often used as a screening tool for radioactivity and includes all alpha emitters such as uranium-234, uranium-235, uranium-238, radium-226, and thorium-230. A gross alpha standard of $15 \mathrm{pCi} / \mathrm{L}$ has been adopted by Utah to protect aquatic wildlife and domestic water supplies. Some water samples were analyzed only for natural uranium; concentrations were expressed in $\mu \mathrm{g} / \mathrm{L}$. These concentrations may be expressed as alpha activity in $\mathrm{pCi} / \mathrm{L}$ by multiplying concentration by the factor 0.68. This method only approximates the total alpha activity and assumes that all of the alpha activity is due to the measured uranium concentration and that U-235 is in equilibrium with U-238.

\section{Boron}

Boron is an element required for the growth of plants, but the difference between required and toxic quantities of boron is very small. Branson (1976) reported that on the basis of extracts from soils, the limits for boron were 5 ppm for semi-tolerant crops such as lima beans, corn, and wheat and 10 ppm for tolerant crops such as onions, alfalfa, and beets. Most criteria and standards for boron in water have been established to protect agricultural uses; however, the California State Water Resources Control Board (1981) recommends a boron limit in water of $750 \mu \mathrm{g} / \mathrm{L}$ to protect fish and wildlife in bay areas receiving irrigation return flows from the San Luis Drain. The Environmental Protection Agency and the State of Utah established the standard for boron in irrigation water at $\mathbf{7 5 0}$ $\mu \mathrm{g} / \mathrm{L}$ to protect sensitive crops. 


\section{Collection and Analysis of Bottom Sediment and Core Cuttings}

Samples of bottom sediment were collected using a BMH-53 sampler with a stainless steel barrel (U.S. Geological Survey, 1977, p. 3-37). Three to four sediment cores were collected in each area from depths of less than 8 in and usually to a depth at which the underlying clay became uniform in color and compacted. The cores were then homogenized using a stainless steel spoon.

Most analytical determinations of trace elements in bottom sediment were performed by the USGS Geologic Division Laboratory in Denver, Colorado. The samples of bottom sediment were air dried, disaggregated, sieved to 230 mesh, and digested with acid prior to analysis. The rigorous digestion procedure included hydrochloric acid, hydrofluoric acid, perchloric acid, and aqua regia. Following digestion, the extracts were processed using methods given by Severson and others (1987). Analytical determinations of arsenic, mercury, and selenium were done by atomic-absorption spectroscopy; uranium and thorium by neutron activation; and all others except boron by inductively coupled plasma analysis. The resulting determinations represented total extractable metals. Boron, however, was extracted using a hot-water method that approximates the biologically available fraction in the sediment. Analytical reporting levels for constituents are shown in table 2. Several samples of core cuttings and sediment from ponds were collected as grab samples and were analyzed only for total selenium content on unsieved samples. Analytical determination of selenium in the core cuttings and bottom material was done by the USGS Water Resources Division Laboratory in Arvada, Colorado, using digestion and hydride-generation procedures in Fishman and Friedman (1985).

\section{Collection and Analysis of Soil}

In November 1988, the USBOR collected 47 soil samples from 16 sites in the area of the drains discharging into Stewart Lake (fig. 6) and 1 sample of shale near the Vernal sewage lagoons adjacent to Ashley Creek. The samples were subjected to several extraction methods to determine if concentrations of total and water-extractable selenium from soils could be used to predict selenium in the drainwater.

The samples were collected using a hand auger, composited by depth interval, and placed in plastic bags or bottles. The USBOR Soils Laboratory in Denver performed saturation and 1:10 extractions using deionized water. Soil samples that were water saturated were split in the laboratory for (1) total soil-selenium analysis, (2) extraction of the pore water, and (3) saturation and 1:10 extractions using deionized water. The extracts and one set of soil samples (from splits) were analyzed for total selenium by the USGS in Arvada, Colorado.

Saturation extractions were done by adding deionized water to a 200-g (dry weight) sample of soil until it was the consistency of paste. The paste was allowed to hydrate for 8 hours and additional water was added, as needed, to keep the paste saturated. The percent-saturation moisture was determined and the paste allowed to sit overnight. The moisture was then removed using a Buchner funnel and the filtrate passed through a filter with a porosity of $0.45 \mu \mathrm{m}$.

The 1:10 extractions were done by adding $400 \mathrm{ml}$ of deionized water to a $40 \mathrm{~g}$ (dry weight) sample of soil. The solutions were capped and shaken for 15 minutes at four intervals during each day for a 4-day period. The liquid was then decanted and filtered using filters with a porosity of $0.45 \mu \mathrm{m}$.

\section{Collection and Analysis of Biological Data}

\section{Survey of Bird Nesting and Collection of Eggs}

Nest searches were done at Stewart Lake WMA, Ouray NWR, Pelican Lake, Pariette Wetlands, and the Winter Storage Pond. Field work to locate nests began about April 15 and ended about July 15 each year. At upland sites, searches were done by walking, occasionally assisted by a bird dog. Where vegetation permitted, ground nesting birds were flushed by pulling a long length of 
chain between two quadratrack vehicles. Nest searches in shallow-water areas were done by walking the perimeter of open water, rarely more than $60 \mathrm{ft}$ into dense emergent vegetation. Where water depth permitted, a canoe was used to assist in locating nests.

Nests were individually marked in an unobtrusive manner, usually by placing a wooden marker in the vicinity of the nest. Nests were visited about weekly until the fate of the nesting attempt was known. Data collected from each nest consisted of species, number of eggs, incubation stage, number of eggs that hatched or failed to hatch, and cause of nest failure such as predation. Incubation stage was estimated using the float technique given in Exhibit IV of the Wetland Management Plan, Ouray NWR (modified from Westerkov, 1950), or by examination of the embryo after an egg was collected. Causes of predation were estimated using criteria presented in Exhibit V, Wetland Managment Plan, Ouray NWR (Lonnie Schroeder, written commun., 1980). Eggs were examined for embryo development using methods developed by Caldwell and Snart (1974). Nests were considered successful if at least one egg hatched (Klett and others, 1986, p. 20). Predation could depress the estimate of actual hatching success if it and initiation of hatching occurred between observation periods and evidence of hatching was destroyed or removed. For consistency, and because nests were not followed through fledging of altricial young, the same criteria were used for our estimates of nesting (hatching) success for herons as was used for waterfowl.

One or more eggs were collected from individual nests for trace-element residue analysis from a variety of species. Random eggs were eggs collected at or before hatching and were not selected because of any observed defects. Eggs were collected from both complete and incomplete clutches. Usually eggs were collected by reaching into the nest and taking one egg without differentiation of any specific eggs. Non-random eggs were eggs collected after incubation was completed and it was determined that these eggs would not hatch. A minimum of five American coot eggs from different nests were collected when available at individual ponds. Eggs of other species, including mallards and black-crowned night herons (Nycticorax nycticorax), were systematically collected with a minimum of three eggs collected from different nests when available. Eggs were maintained at ambient temperature until examined the same day. On rare occasions (but usually with unhatched goose eggs) eggs were not processed immediately but were refrigerated until processed. Unhatched eggs were examined for fertility and embryo health. Egg volume was measured by water displacement to the nearest $1 \mathrm{ml}$, length and width with calipers to the nearest $0.1 \mathrm{~mm}$, and gross weight of egg (and contents) and net weight of contents with an electronic scale to the nearest $1 \mathrm{~g}$. Eggs usually were opened by cracking the air cell end with chemically cleansed forceps and breaking the shell away until the contents could be removed. The egg contents were examined for stage of embryo development, viability, and deformities. Egg contents were placed in chemically cleansed jars and stored frozen. Most tissues were analyzed for inorganic elements, but a limited number were also analyzed for organochlorine compounds. Most eggs were analyzed individually, but two or more eggs of blackbirds were composited to form one sample because of their small size.

\section{Waterbird Observations}

During 1988 and 1989 waterbird use was observed at Stewart Lake WMA, Winter Storage Pond, North Roadside Pond, and Pariette Wetlands at one to two week intervals from spring through mid-summer. Formal observations included species present, estimated numbers, and activities. Observations were less formally made at other times and sites as opportunity provided. Brood observations including number, species, and location were made by the authors in 1988 and by Ouray NWR personnel in 1987-89.

\section{Collection of Bird Tissue}

Waterfowl were collected with steel shot during the 1988 fall migration at the Winter Storage Pond, Stewart Lake WMA, and Leota Bottom of Ouray NWR, and in the spring of 1989 at Pelican Lake and Leota Bottom. Limited numbers of waterfowl were taken by volunteer hunters using lead shot. Whole livers and parts of breast muscle were removed for analysis and placed in chemically cleansed 
jars or wrapped in aluminum foil (unrinsed, shiny side out) prior to being stored frozen. Likewise, liver tissue was collected from flightless juvenile American coots at Pelican Lake, the Roadside Ponds, Sheppard Ponds S3 and S5, and Leota Bottom Pond L6 at Ouray NWR and at five sites in Pariette Wetlands in 1987.

Suitable samples of liver or kidney tissue for chemical analysis were salvaged from birds found dead. Birds suitable for necropsy were sent to the National Wildlife Health Laboratory in Madison, Wisconsin, or the Colorado Veterinary Diagnostic Laboratory, Colorado State University.

\section{Collection of Eagle Blood}

Bald eagles (Haliaeetus leucocephalus) and golden eagles (Aquila chrysaetos) were captured live in 1988 and 1989 during spring migration at Ouray NWR and nearby areas using the methods reported by Bloom (1987). Captured birds were weighed, measured, and banded, and blood samples were collected. Blood was analyzed for lead in 1988; selenium, arsenic, and mercury in 1988 and 1989; and scanned for a wide range of elements using Inductively Coupled Plasma (ICP) analysis in 1989.

\section{Collection of Fish}

Fish were collected at Stewart Lake WMA; Sheppard Bottom Ponds S3 and S5, South Roadside Pond, and Leota Ponds L3 and L6 at Ouray NWR; and Gadwall, desiltation, and Big Island Ponds at Pariette Wetlands during early spring and mid-summer during 1986-89. Samples were collected once at Ashley Creek, Winter Storage Pond, Pelican Lake, Flood Control Pond at Pariette Wetlands, and at five sites on the Green River (near Browns Park NWR, Echo Park, Jensen, Ouray, and upstream of the town of Green River).

Most fish samples were obtained using gill nets during early spring and mid-summer. Fish were also collected using hook and line, electro-shocking, and dip nets. Most samples were a composite of five adult fish of similar size. A few of the composite samples had less than five fish because of their limited availability. Three or more composite samples were obtained from most sites sampled. Fish were weighed, measured, and double-bagged in plastic bags or placed in chemically cleansed jars prior to being stored frozen. Samples to be analyzed for organochlorine compounds were wrapped in aluminum foil (unrinsed, shiny side out) and then placed in plastic bags.

A small number of samples were processed in a different manner. Fillets were collected from a few fish samples to evaluate potential hazards of consumption by humans. Some samples of small fish had only the weight of the composite sample measured.

One sample of eggs from the endangered razorback sucker was obtained for analysis from the Green River near Jensen, Utah, by personnel of the Colorado River Fishery Project (CRFP). In addition, tissues of several other endangered fish archived by CRFP were analyzed.

\section{Collection of Invertebrates}

Several species of invertebrates were obtained with the use of light traps (Espinosa and Clark, 1972). Traps were set at the Roadside Ponds, Sheppard Bottom Pond S3, and Leota Bottom Pond L6 at Ouray NWR, at the desiltation and Gadwall Ponds at Pariette Wetlands; and at Stewart Lake during 1988-89. Other sites were similarly sampled at irregular time intervals. Usually all invertebrates collected in the traps were included in the composite samples. Occasionally a trap would include a specimen of Coleoptera; these were analyzed separately because of their large size. The composition of the sample was estimated in weight percent according to taxonomic order. Assistance in identification and quantification was provided by Dr. Steven Romney of the Uintah Basin Mosquito Abatement District. Excess water was poured off the samples, which were placed into chemically cleansed jars and stored frozen. Additional invertebrate samples, including damselfly (Odonata) larvae and snails (Gastropoda) were opportunistically collected using invertebrate nets or by hand. 
A few samples of invertebrates were obtained from fish stomachs. The contents of up to 10 fish stomachs were composited into a single sample representing primarily a single family of invertebrates.

\section{Collection of Plants}

Sites where aquatic plants were collected included the Roadside Ponds, Sheppard Bottom Ponds S3 and S5, and Leota Bottom at Ouray NWR; J1, J3, J4 drains and at the outlet of Stewart Lake; marsh 4720; several sites in the Winter Storage Pond; Pelican Lake inlet and outlet areas; and most major impoundments at Pariette Wetlands. Sampling schedules varied by site, season, and year. Species collected included those commonly available and also those considered important as food for aquatic birds. Plants collected consisted of the non-rooted sections, except for cattail (Typha sp.) and hardstem bulrush (Scirpus acutus). The cattail samples usually consisted of 6-8 in. of stem starting at the root/stem interface and 6-8 in. of root, except for samples collected in 1986 that were entire plants. The bulrush samples usually included the entire rooted plant, but in 1989 some 6-8 in. samples of stem and root were collected similar to the cattail. All samples were composite samples. Plant samples were double bagged in plastic, frozen, and analyzed for inorganic elements only. Samples of cattail and bulrush seed also were collected, but the seed was stripped from the stalk and the chaff was not separated from the seed.

\section{Selenium Uptake by Captive Mallards}

Forty-four captive-reared mallards of equal sex ratio with pinioned wings were released at the Roadside Ponds at Ouray NWR in 1989 to determine the rate at which these birds would take up selenium from the local environment. Each bird was weighed, banded, and visually marked using numbered wing badges (Gey Band \& Tag Co., Inc.; 374-7A, aluminum bands; VWB-951, hen badges). The dike at the South Roadside Pond was fenced with poultry netting to prevent escape downstream. A control sample of six additional birds from the same stock was sacrificed prior to releasing the experimental birds into the environment to establish baseline data on inorganic elements in the released birds. The design called for three males and three females to be sacrificed at the end of the first, second, fourth, and sixth week post-release. All birds retrieved were sent to the College of Veterinary Medicine at Colorado State University for gross necropsy. Liver and breast tissue were removed and analyzed for inorganic elements. Samples of water, sediment, invertebrates, and plants were collected concurrently from the same areas the birds were inhabiting.

\section{Analysis of Biological Tissue}

Tissue samples were analyzed at the USFWS, Patuxent Analytical Control Facility at Laurel, Maryland, and other labs under contract with the USFWS. Concentrations of the following elements were determined: aluminum, arsenic, barium, beryllium, boron, cadmium, copper, iron, lead, magnesium, manganese, mercury, nickel, selenium, tin, vanadium, and zinc. The analytical procedures consisted of an inductively coupled plasma scan without preconcentration for most elements. Selenium and arsenic were analyzed by hydride generation, and mercury by cold-vapor using standard methods. Several tissue samples were analyzed for organochlorine pesticides. The analytical procedure for pesticides consisted of solvent extraction and analysis using electron-capture gas chromatography.

Concentrations of elements in biological tissue are reported on the basis of dry weight except where compared to values from literature that originally were reported only as wet weight or when values are compared with standards for consumption that are always given in units of wet weight. The quantification of many trace elements in biological tissue resulted in values that were reported as "less than". While this affected most elements analyzed by ICP scan, selenium, the primary element of concern in this study, rarely was affected. Most elements were not found in concentrations known to cause an adverse biological effect; however, selenium was often found in concentrations known to be harmful to biota. Methods of treating "less thans" in some studies involve substitutions that have no theoretical justification and may result in data summaries that are inappropriate (Helsel, 1990). Where summary statistics such as mean are presented for selenium or where a statistically significant 
relation for an element of biological significance was suspected in this report, values for "less thans" have been treated using non-parametric procedures for censored data as given by Helsel (1990), and median values were used in calculations because they approximate the geometric mean. Analytical data are reported in tables by sample type. Individual samples consisted of tissue from a single individual. Composite samples consisted of the combined tissue from generally three to five individuals. Sample size presented in tables represents the number of individual or composite samples summarized.

\section{Preparation of Figures Using a Geographic Information System}

Many of the figures in this text were prepared using maps in a digital format. When digitizing was necessary, the data were digitized from the smallest scale stable map available, usually 1:24,000. Figures based on aerial photographs were geo-referenced using 1:24,000 scale maps and a 3-point latitude-longitude method to assure geographic location. Digitizing was completed within a root mean square error not greater than 0.003 . Most of the area maps were available as Digital Line Graphs with a scale of $1: 100,000$ that were produced by the USGS.

\section{HYDROLOGY AND CONTAMINANTS IN BIOTA IN AND NEAR STEWART LAKE WATERFOWL MANAGEMENT AREA}

\section{Hydrology and Water Quality}

The source of most of the water in the area of Stewart Lake WMA is Red Fleet Reservoir on Brush Creek, with a capacity of 26,000 acre-ft. The reservoir was originally planned to deliver 18,000 acre-ft of municipal and industrial water annually and only 4,600 acre-ft of irrigation water, but development in the Vernal area never materialized, and about 16,000 acre-ft of municipal and industrial water remains unused. Presently, most of the discharge from Red Fleet Reservoir is used for irrigation in the Jensen area. Water is released typically from March or April to October (fig. 10). The median monthly discharge during water years $1986-89$ was 2,011 acre-ft; however, during the unusually dry years of 1988-89, the median monthly discharge was only 1,219 acre-ft. Water is delivered to the Jensen area by Brush Creek and diverted into the Sunshine, Burns Bench, and Burton Canals for irrigation. Five subsurface drains remove water from the irrigated areas and discharge to Stewart Lake, providing virtually all of the surface-water inflow.

Locations of wells, surface-water sites, and biological data-collection sites near Stewart Lake are shown in figures 11 and 12 . Local ground-water flow in the Jensen area is bound vertically by the relatively impermeable Mancos Shale; little if any, water rises through the shale (Hood, 1977). Ground water is discharged from the Jensen area by drains, seeps, wells, evapotranspiration, and subsurface flow to the Green River. Total discharge was not quantified in this study.

\section{Water Type and Recharge in the Jensen Area}

Irrigation water, diverted from Brush Creek and supplied to the Jensen area by canals, was typically a calcium sulfate bicarbonate type water (fig. 13a). As the water flowed through evaporite soils rich in gypsum, calcium was replaced with sodium through exchange with sodic clays or lost through precipitation of carbonate minerals, and the water became a sodium sulfate type (fig. 13b). Dissolved-solids concentrations in the drainwater typically increased ten fold from concentrations in the irrigation water, due to dissolution of soil salts. The water type typically found in shallow wells in the Jensen area was a sodium sulfate type and was similar to the drainwater discharged to Stewart Lake (fig. 13c).

Recharge to the unconsolidated basin fill is by seepage from canals, unconsumed irrigation water, and precipitation. Most of the recharge to the unconsolidated basin-fill aquifer is to the shallow ground-water zone from the surface to $50 \mathrm{ft}$ below land surface and moves from the recharge areas toward the discharge areas of Stewart Lake and the Green River. 


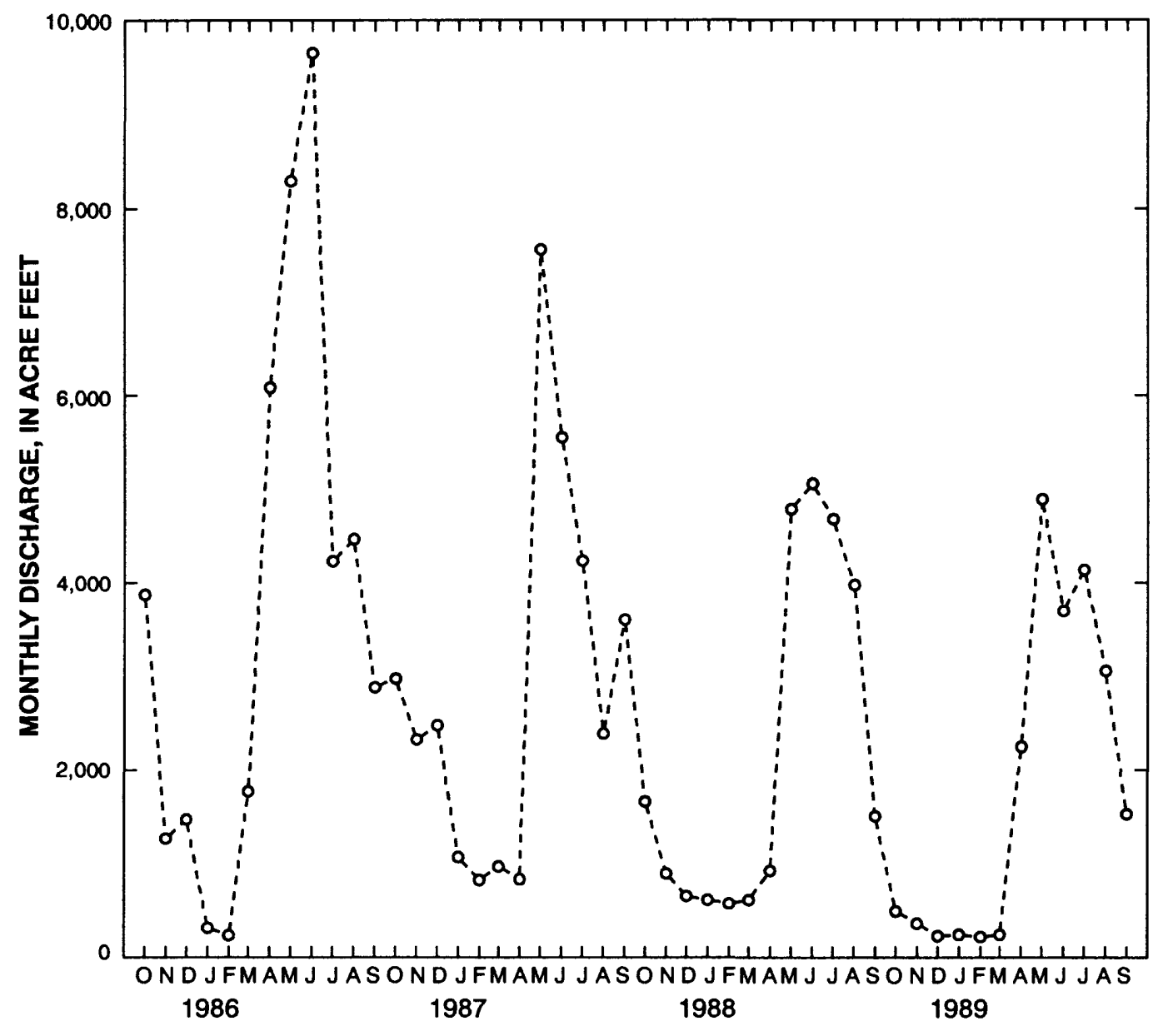

Figure 10. Monthly discharge from Red Fleet Reservoir, water years 1986-89.

A generally positive relation between selenium concentrations and the number of tritium units (TU) in irrigation water and drainwater collected in August 1988 from the Jensen area is shown in figure 14. Irrigation water diverted from Brush Creek typically contained selenium concentrations that did not exceed $12 \mu \mathrm{g} / \mathrm{L}$, and TU were within the range of 4 to $25 \mathrm{TU}$ for modern-day precipitation (Gat, 1980, p. 22). It was not possible to determine accurately when recharge occurred using the tritium data because the drains continually accrue water of different recharge age as they approach Stewart Lake. The most recent month in which an appreciable quantity of precipitation (as measured in Salt Lake City and decayed through August 1988) contained tritium that exceeded 29 TU (the minimum value in water from the drain outflows) was August 1981, suggesting that at least some of the water entering all drain lines except J1A was deposited as rainfall prior to August 1981.

Selenium concentrations and the numbers of TU were generally largest in drainwater taken from each point of discharge to Stewart Lake (J1-J4). The discharge is composed of drainwater from all laterals and is the oldest water in the drain. This age relation indicates slow rates of transport for water and, therefore, the longer contact time between soil and water allows more selenium to be extracted. Alternatively, the selenium is associated with clay soils that have small values of hydraulic conductivity and drain slowly. Water with the largest number of TU and a generally large selenium concentration was collected from access hole J2-62 in very consolidated clay soil (Clark Whitlock, U.S. Bureau of Reclamation, oral commun., 1989). The smallest selenium concentrations and TU were present in water from the J1A drain system which, with a flow path of about $2,000 \mathrm{ft}$, is the shortest drain and is in a fine sandy loam. 


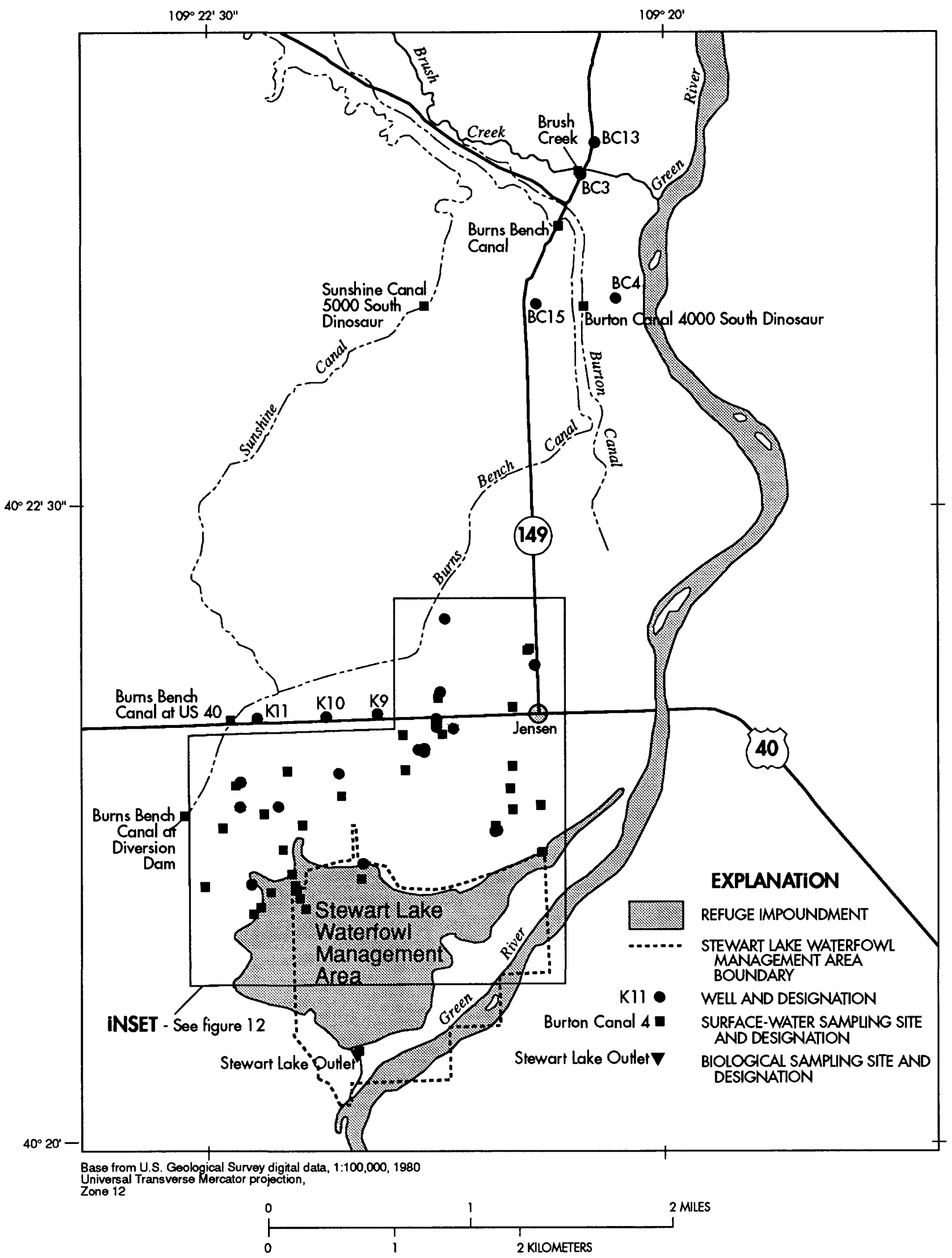

Figure 11. Locations of wells and surface-water and biological sampling sites in the area of Stewart Lake Waterfowl Management Area and Brush Creek near Jensen, Utah. 


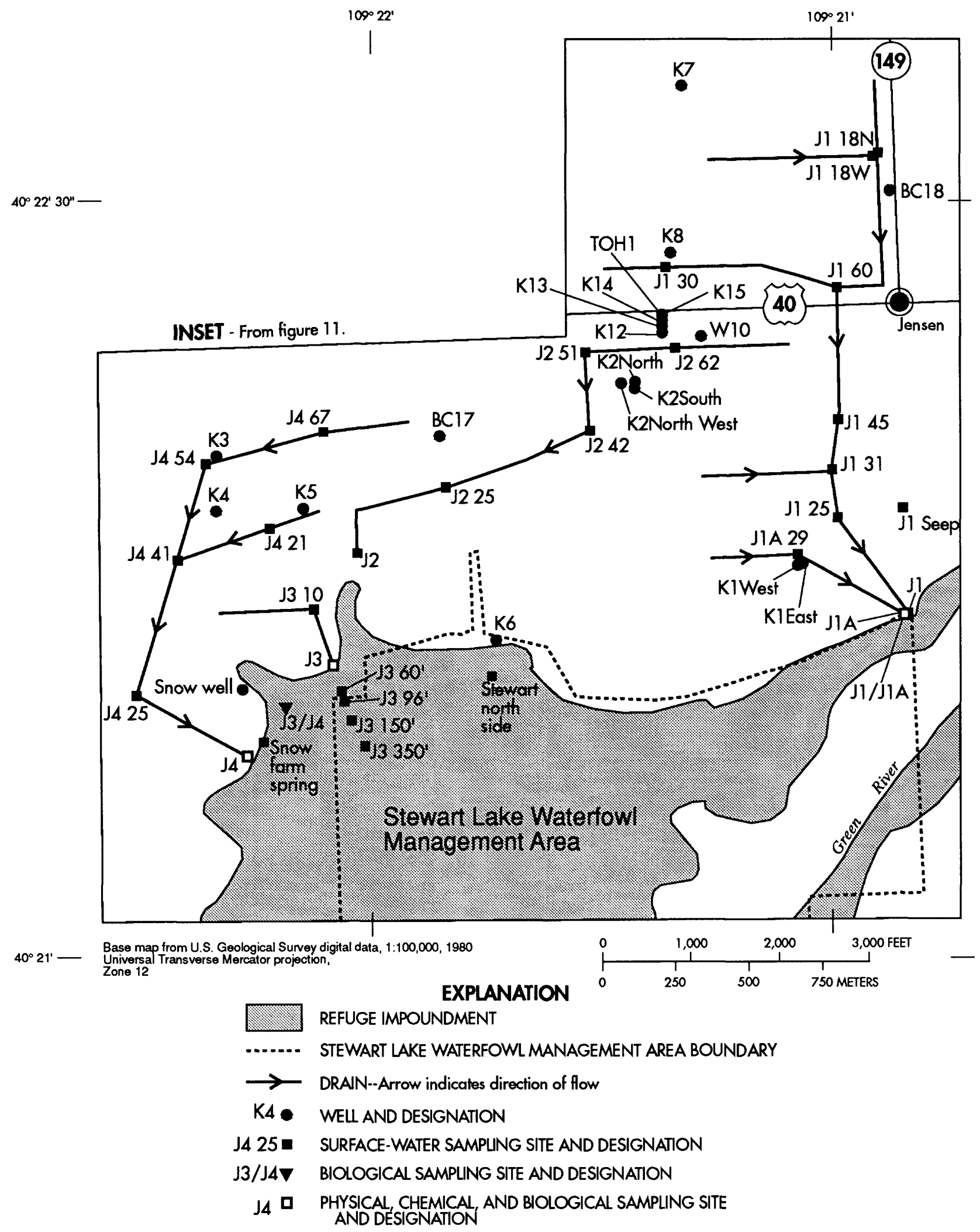

Flgure 12. Locations of wells and surface-water and biological sampling sites in the area north of Stewart Lake Waterfowl Management Area, Jensen, Utah. 

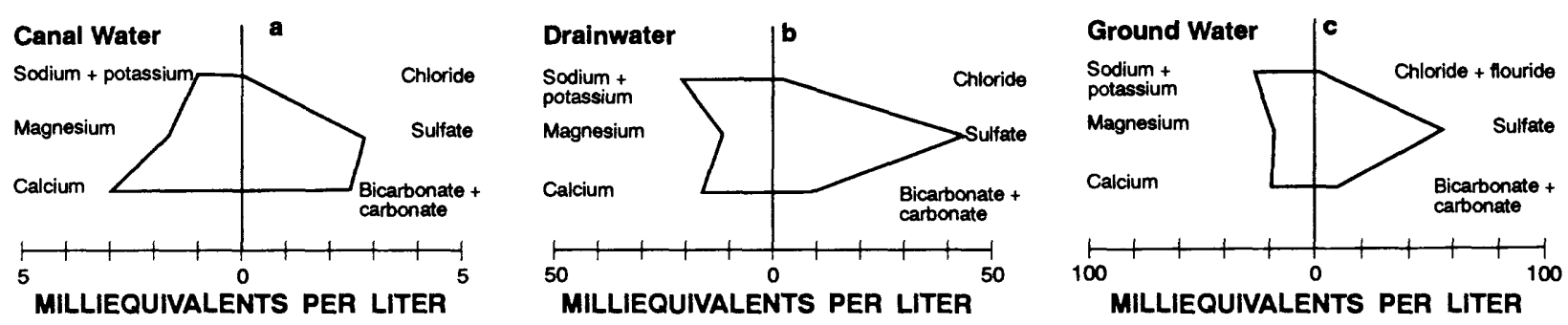

Note differences in horizontal scales

Figure 13. Concentrations of major ions in: $a$, canal water delivered to irrigated land near Stewart Lake; $b$, irrigation drainage discharged to Stewart Lake; and c, shallow ground water from a well near the $\mathrm{J} 3$ drain.

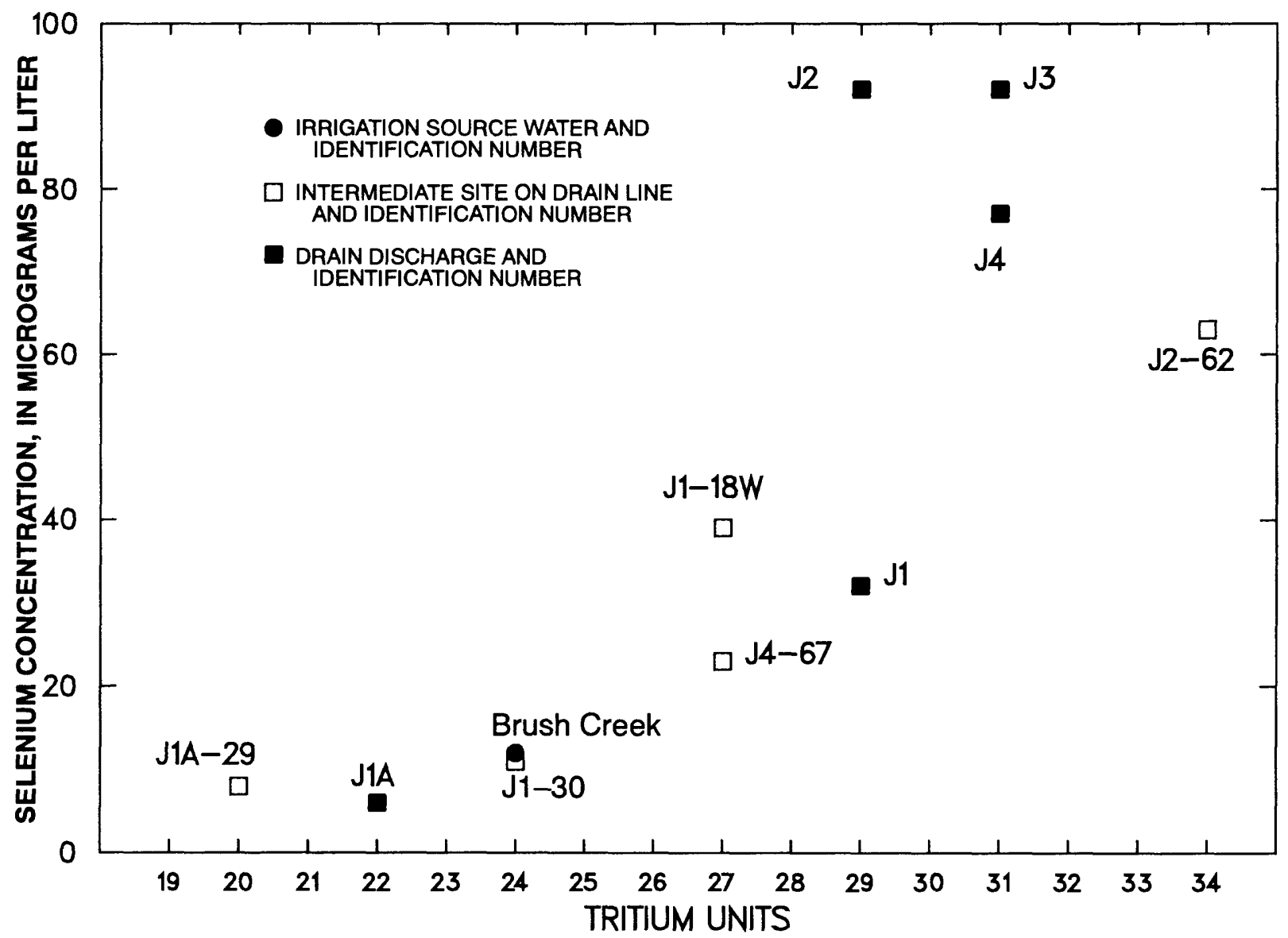

Figure 14. Relation of selenium concentration to tritium units in water from Brush Creek and U.S. Bureau of Reclamation drains in the Jensen, Utah, area, August 1988.

There was little variation in concentrations of stable hydrogen and oxygen isotopes in irrigation water, drainwater, or well water in the Jensen area (fig. 15). All data plot beneath the global meteoric water line indicating some evaporative enrichment of the heavier isotopes, but a valid evaporative trend line could not be constructed. 


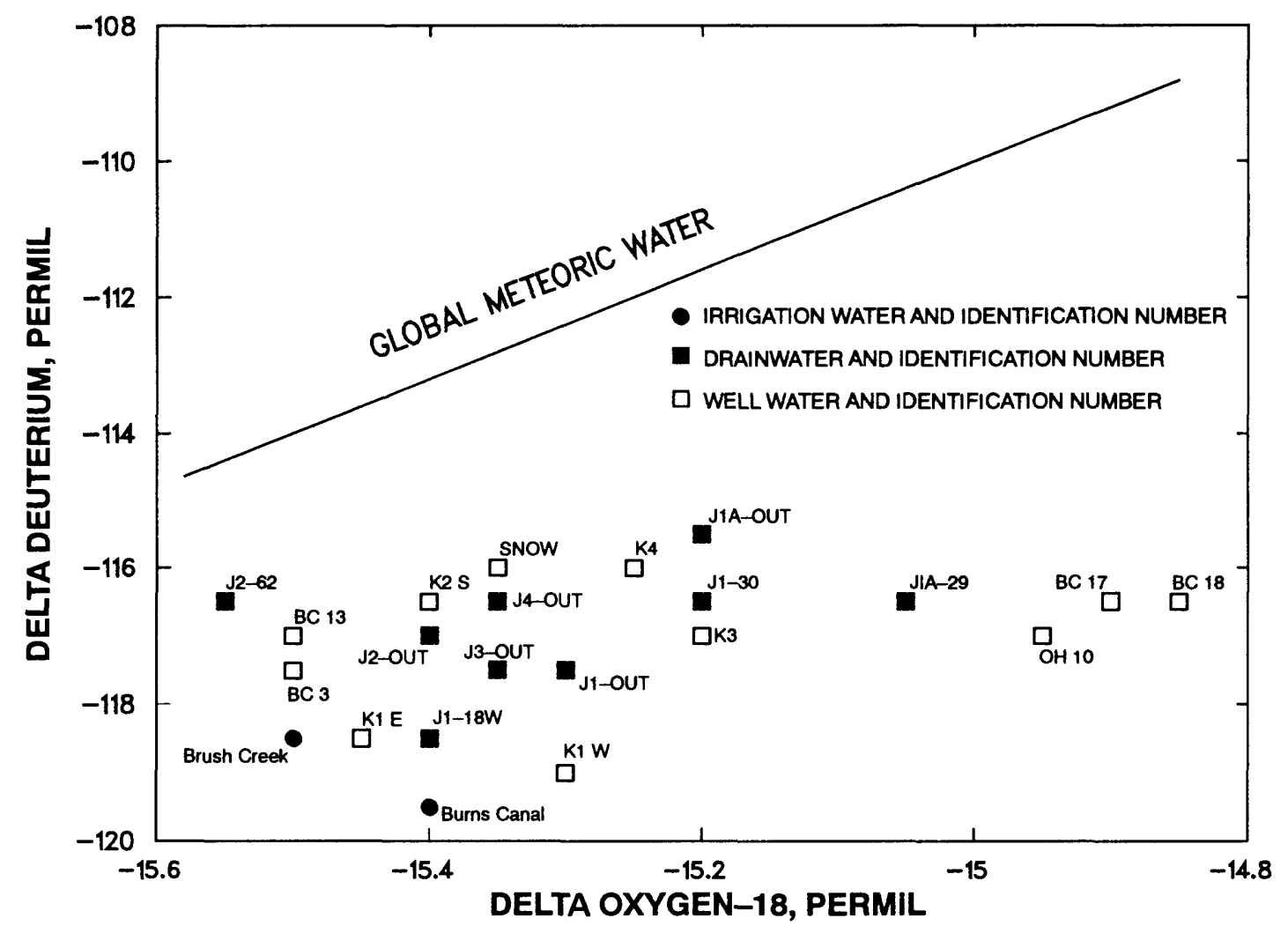

Figure 15. Relation of delta deuterium to delta oxygen-18 stable isotopes in irrigation water, drainwater, and well water in the Jensen, Utah, area.

\section{Hydraulic Conductivity and Flow Rates Near Drains}

The USBOR measured the hydraulic conductivity of soils in the Jensen area prior to installation of the drains. These measurements were made by determining the individual auger-hole permeability in clay and silt soils, or by pump tests in gravel soils. The data and the large quantity of variability in the 24 measurements is summarized in figure 16 . The median hydraulic conductivities within the drain fields were near $6 \mathrm{ft} / \mathrm{d}$ and ranged from 1.2 to $600 \mathrm{ft} / \mathrm{d}$. Although there were few data for the J3 and J4 drains, there was generally an inverse relation between the mean selenium concentrations in the outflow from each drain and the hydraulic conductivities, near each drain line. Drain J1 services an area with the largest median and range of hydraulic conductivities, and water discharging from this line had the smallest concentrations of selenium. (Drain J1A was not considered as there were no values for hydraulic conductivity near the drain.) Drains J3 and J4 contained large selenium concentrations, and the hydraulic conductivities ranged from 3 to $9.4 \mathrm{ft} / \mathrm{d}$.

Most of the values for hydraulic conductivity were determined for surface zones of about $5 \mathrm{ft}$ in depth, but data for four wells included conductivities for two depth zones. In all four of these wells, the hydraulic conductivity of the near-surface zone was much less than the deeper zone. Values determined for the near-surface zones were for zones as deep as $10.6 \mathrm{ft}$ but were typically $6 \mathrm{ft}$. Values for deeper zones were taken from as deep as $28.5 \mathrm{ft}$ but were typically from $22 \mathrm{ft}$. Hydraulic conductivities for the near-surface zones ranged from 2 to $7 \mathrm{ft} / \mathrm{d}$ and for the deeper zones ranged from 54 to $600 \mathrm{ft} / \mathrm{d}$. These differences likely result from the depositional pattern of fine material overlying coarse gravel for the alluvial deposits forming the soils in the area. 


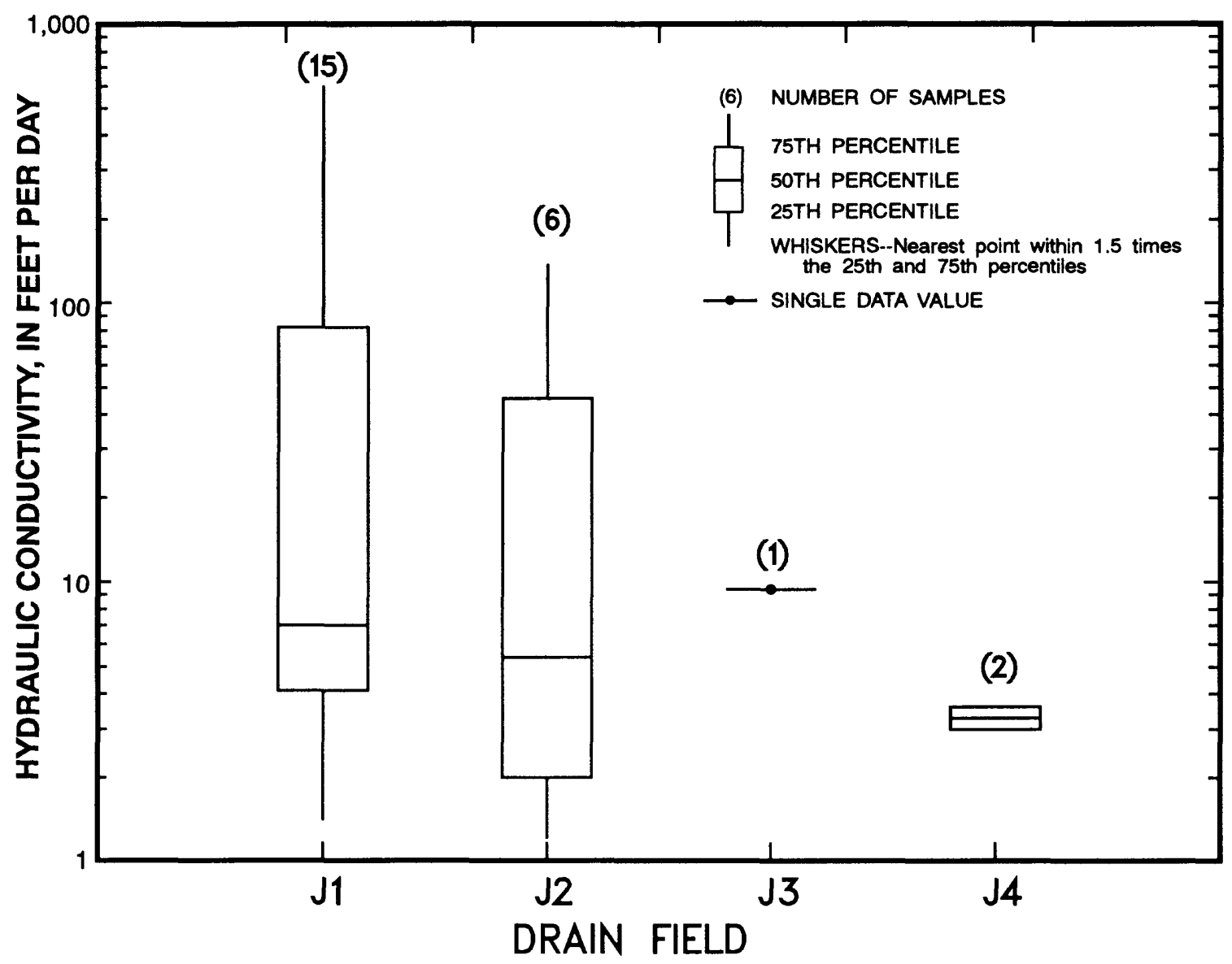

Figure 16. Values for hydraulic conductivity of wells in the major drain fields near Stewart Lake.

Because the hydraulic conductivity is actually a measure of the volume rate of flow through a unit cross section, it does not provide the best estimate of the actual rate of movement of particles of water through a porous substrate. There must also be a driving force, usually given as slope, and a measurement of the porosity of the substrate. This is typically represented by the Darcy equation (Lohman, 1979, p. 11)

$$
\bar{v}=\frac{K\left(\frac{d h}{d l}\right)}{\text { theta }}
$$

where $\bar{v}$ is average velocity, $K$ is hydraulic conductivity, $d h / d l$ is slope between two points, and theta is effective porosity. It should be stressed that this gives the average velocity and may not accurately represent the rate of movement between any two points in the aquifer.

Values for hydraulic conductivity typically range from $1 \mathrm{ft} / \mathrm{d}$ for clay to $800 \mathrm{ft} / \mathrm{d}$ for gravel or very coarse sand (Lohman, 1979, p. 53). Values for effective porosity are typically 0.34 to 0.57 for clay and 0.25 to 0.44 for gravel (Morris and Johnson, 1967; Wenzel and Fischel, 1942). Estimates for average velocity were calculated for several areas in Jensen using measured values for hydraulic conductivity and approximate elevations and distances from field drawings provided by the USBOR (J.B. Miller, written commun., 1990). An area serviced by the J2 drain had the smallest value for hydraulic conductivity $(1.2 \mathrm{ft} / \mathrm{d}$ ). If the soils were characterized by clay, the average velocity for flow 
in this area would be $0.04 \mathrm{ft} / \mathrm{d}$. Conversely, the largest hydraulic conductivity was $600 \mathrm{ft} / \mathrm{d}$ in an area near the outflow of the J1 drain. The average flow velocity for this area would be $23 \mathrm{ft} / \mathrm{d}$. Most of the drains are in areas with a slope of about $1 \mathrm{ft}$ per $100 \mathrm{ft}$. Using a "typical" hydraulic conductivity of $6 \mathrm{ft} / \mathrm{d}$ and effective porosity values of 0.25 for gravel and 0.4 for clay, the average velocity of water moving through the soils would range from about 0.15 to $0.24 \mathrm{ft} / \mathrm{d}$. If a volume of water applied to the land surface had to travel $6 \mathrm{ft}$ vertically and $300 \mathrm{ft}$ horizontally to reach a drain lateral (a reasonable estimate), it could take from 3.5 to 5.6 years.

Drains in the Jensen area are spaced at least $600 \mathrm{ft}$ apart and are generally 8 to $10 \mathrm{ft}$ above the impermeable shale. The inflow of ground water into the drains in the Jensen area is dependent on the hydraulic conductivity and permeability of the soil, rate of application of irrigation water, slope or gradient, and depth to the drains. Analysis of water levels from four wells (K12-K15) installed perpendicular to the J2 drain lateral indicated an average ground-water-flow gradient of 0.0019 toward the drain (Kirchner, 1991, p. 34).

\section{Ground-Water Flow and Selenium in Wells in the Jensen Area}

Several of the wells (TOH 1 and W 10) monitored in the Jensen area (figs. 11 and 12) were installed by the USBOR about the time the drains were installed. Wells identified by the letters BC were installed about 1985 as part of a salinity-control project. The Snow well and the wells identified by the letter $\mathrm{K}$ were installed for this study in 1988-89.

Movement of shallow ground water in the Jensen area is generally to the south and east toward Stewart Lake and the Green River. The contouring of the water table of shallow ground water in July 1989 is shown in figure 17. (Data from wells in the Jensen area and two locations on the Green River were used to contour the water-level elevations. The elevations of the Green River were calculated from the river stage measured at USGS station 09261000 near Jensen, Utah. These points were used to establish discharge locations along the Green River.) Water-level contours during July indicate a typical water-table profile of an irrigated area where the highest water levels occur in middle to late summer in response to the application of irrigation water, and the lowest water levels occur in winter. Ground-water flow is perpendicular to the contour lines and moves downgradient toward Stewart Lake and the Green River.

Water levels in all monitored wells declined from the end of the irrigation season in September to spring, when irrigation started. Water levels for two representative wells in the Jensen area are shown in figure 18. Both wells are near U.S. Highway 40 in an area where water levels typically fluctuated 5-10 ft during the year. Wells adjacent to Stewart Lake typically fluctuated 2-4 $\mathrm{ft}$ during the year.

Wells $\mathrm{K} 12-15$ were drilled to determine differences in water-table elevation in a single field near drain J2 (fig. 12). Water levels in wells K12-15 showed that the water table did not decrease toward the buried drain lateral over the distance of the four wells. Well K15, farthest from the drain lateral, consistently had the lowest water level, which is likely the result of anisotropic conditions in the geologic formation as evidenced by the wide range of hydraulic conductivities in the area.

Wells farthest from the drain laterals had the largest water-level fluctuations. Water levels in wells $\mathrm{K} 1, \mathrm{~K} 2-\mathrm{K} 5$, and $\mathrm{K} 8$, located very close to the drain laterals for the J1A, J4, and J1 drains, fluctuated about 3-4 ft. Wells $\mathrm{K} 9-\mathrm{K} 11$ were more than $1,200 \mathrm{ft}$ from the $\mathrm{J} 1$ drain laterals and were separated from the J4 laterals by U.S. Highway 40 . Water-level fluctuations in these wells were about $10 \mathrm{ft}$ (Kirchner, 1991, p. 34).

Selenium concentrations in 17 shallow wells in the Jensen area were variable and ranged from $<1$ to $360 \mu \mathrm{g} / \mathrm{L}$ (median of $20 \mu \mathrm{g} / \mathrm{L}$ for 59 samples), but the larger concentrations generally occurred in wells located within drain areas for the J2, J3, and J4 drains (fig. 19). These drains also discharged the largest selenium concentrations into Stewart Lake. Median selenium concentrations in water from two wells (BC 3, BC 13) adjacent to Brush Creek near State Road 149 were 26 and $92 \mu \mathrm{g} / \mathrm{L}$ (fig. 19). 


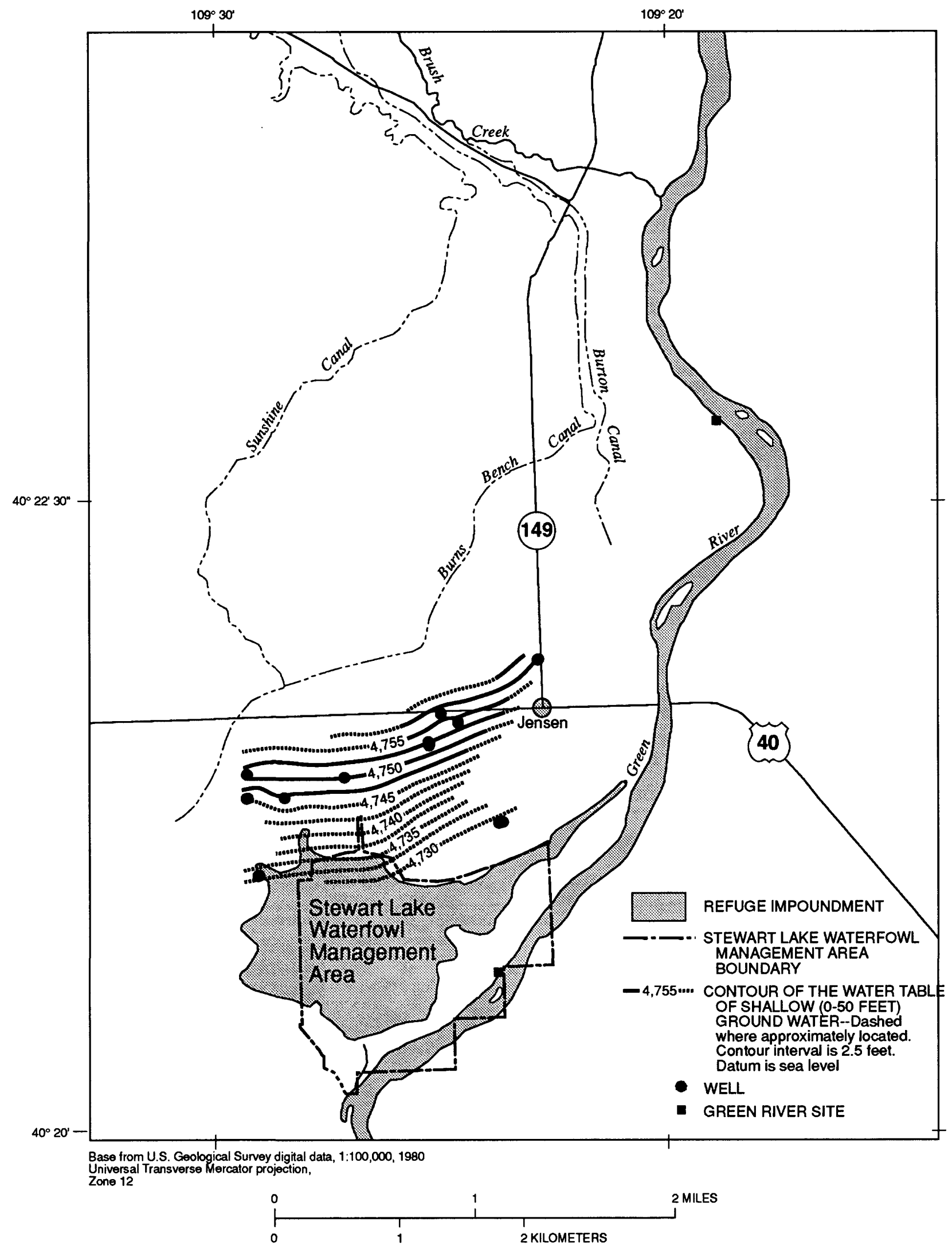

Figure 17. Contours of the water table of shallow (0-50 feet) ground water near Stewart Lake Waterfowl Management Area in July 1989. 


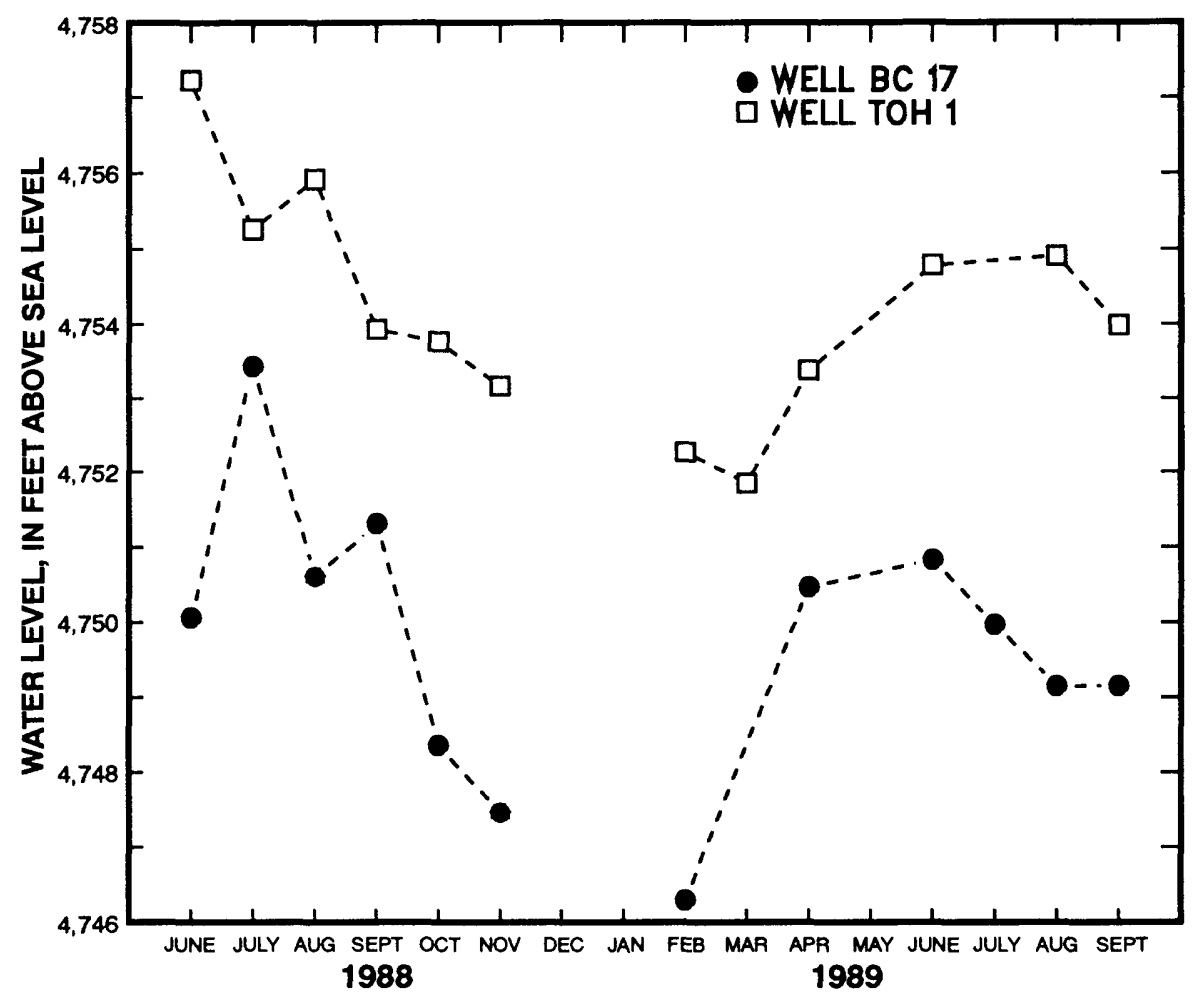

Figure 18. Water levels in two wells in the Jensen, Utah, area.

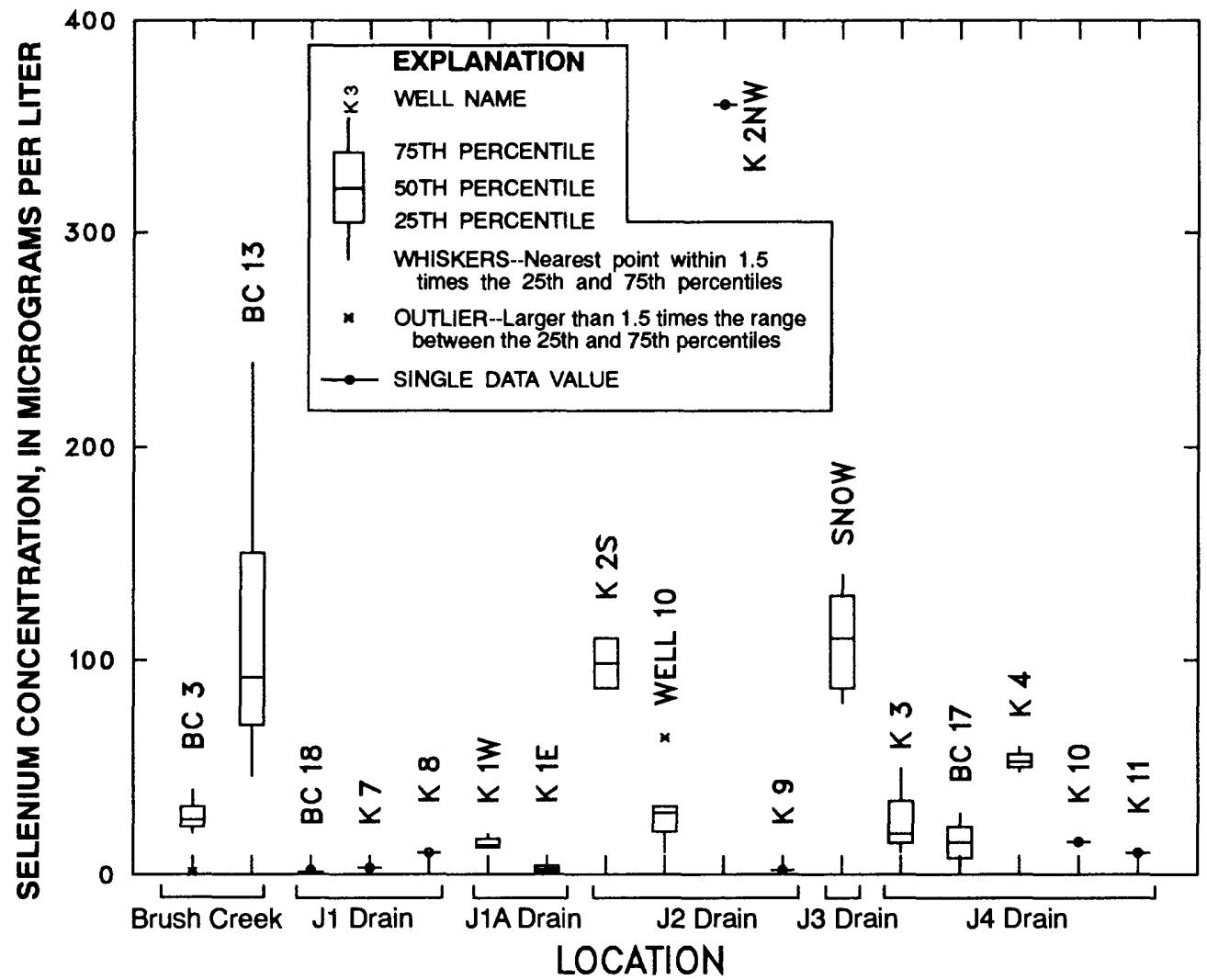

Figure 19. Selenium concentrations in well water from areas near Brush Creek and from five drain fields in Jensen, Utah, water years 1988-89. 
Water in this area drains directly into the Green River and does not enter the Stewart Lake area. Water from five wells in drain areas for the J1 and J1A drains contained generally small quantities of selenium, with median concentrations that did not exceed $14 \mu \mathrm{g} / \mathrm{L}$. Selenium concentrations in wells within the J2 drain area were extremely variable, ranging from 1 to $360 \mu \mathrm{g} / \mathrm{L}$ in the four wells. Two of the wells, K2 South and K2 Northwest are within $6 \mathrm{ft}$ of each other and both are only 9 to $10 \mathrm{ft}$ deep, yet the median selenium concentration in $\mathrm{K} 2$ South was about $100 \mu \mathrm{g} / \mathrm{L}$ and a single sample from the $\mathrm{K} 2$ Northwest well contained $360 \mu \mathrm{g} / \mathrm{L}$. The reason for this difference is not known but illustrates the variability of selenium concentrations in area ground water.

Selenium concentrations in the only well in the J3 drain area were typically near $100 \mu \mathrm{g} / \mathrm{L}$, slightly larger than the median of $77 \mu \mathrm{g} / \mathrm{L}$ in drainwater from this area. Wells within the J4 drain area contained water with selenium concentrations ranging from 2 to $60 \mu \mathrm{g} / \mathrm{L}$.

\section{Selenium in the Inflow and Outflow of Stewart Lake}

Stewart Lake acts as a sink for selenium discharged by the drains. Summary statistics for selenium in each of the drains and the outflow to the Green River during the 1986-87 and 1988-89 water years are compared in figure 20. During both periods, median selenium concentrations from every drain exceeded the $5 \mu \mathrm{g} / \mathrm{L}$ standard established by the State of Utah for wildlife protection, and 98.8 percent of all samples of drainwater exceeded $5 \mu \mathrm{g} / \mathrm{L}$. The lake, however, retained a sufficient quantity of selenium such that the discharge to the Green River exceeded the standard of $5 \mu \mathrm{g} / \mathrm{L}$ in only 80 percent of the samples. The largest concentrations and generally the largest variability occurred in the most recently completed (1981) drains, J3 and J4. The J1, J1A, and J2 drains were completed between 1979-80, and water in them varied the least in concentration.

The total quantity of selenium retained by Stewart Lake was substantial. A comparison of the median concentrations and loads of chloride, a conservative constituent, compared to medians for selenium, a nonconservative element, is shown in table 3. Stewart Lake discharged a total daily load of chloride that was about equal to the total daily load entering the lake through the drains; however, only about 25 percent of the total load of $252 \mathrm{~g}$ of selenium entering the lake was discharged to the Green River. Almost $200 \mathrm{~g}$ of selenium per day were retained by the lake in sedimentary deposits or incorporated into microbes and aquatic plants. Discharge data for the drains for 1979-89 and discharge data for the outflow for water years 1988-89 were used to calculate loads. The selection of a recent period for the outflow was done to avoid the years from 1983 to 1987 when the Green River flooded Stewart Lake. All concentration data were for water years 1988-89.

The summary statistics in figure 20 also show only small variations in selenium concentrations in the combined flow of the $\mathrm{J} 1$ and J1A drains and the J2 drain during the two time periods. Median selenium concentrations declined from 110 to $75 \mu \mathrm{g} / \mathrm{L}$ in the $\mathrm{J} 3$ drain and from 89 to $74 \mu \mathrm{g} / \mathrm{L}$ in the J4 drain between 1986-87 and 1988-89. The range of measured values also declined. While these values suggest a declining trend in selenium concentrations with time, the 1986-87 data consist of only four measurements, and concentration data were not flow adjusted.

Selenium enters Stewart Lake from seepage in addition to discharge from the ground-water drains. Residents of the area indicate that prior to the installation of the drains, considerable seepage discharged to the land surface along the north shore of the lake. During 1987-89, samples of seepage were collected at several sites on the north shore between the outflows of the J1 and J3 drains. Water in one sample from a metal pipe protruding from the ground between the J1 and J2 drains contained a selenium concentration of $17 \mu \mathrm{g} / \mathrm{L}$ with a measured discharge of about $20 \mathrm{gal} / \mathrm{hr}$; the second water sample taken nearby contained $8 \mu \mathrm{g} / \mathrm{L}$ selenium with an estimated discharge of $50 \mathrm{gal} / \mathrm{hr}$. A seep 100 yds west of the outfall of the J3 drain contained water with $110 \mu \mathrm{g} / \mathrm{L}$ selenium and an estimated discharge of $2,000 \mathrm{gal} / \mathrm{hr}$. 


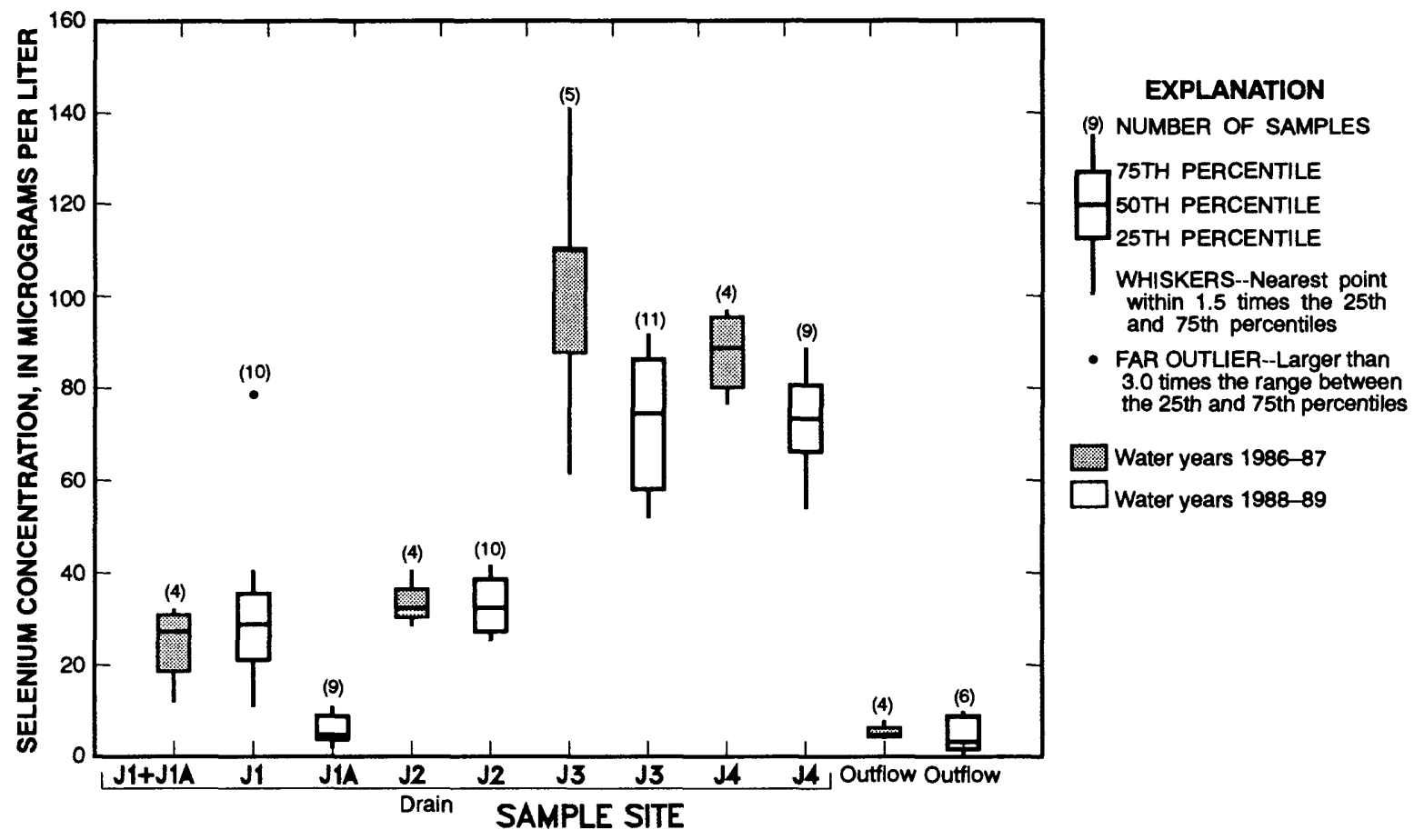

Figure 20. Selenium concentrations in drainwater discharged to Stewart Lake and in the outflow to the Green River for water years 1986-87 and 1988-89.

The concentration of major ions was determined in only one sample of seepage, collected about $150 \mathrm{ft}$ north of the outfall for the $\mathrm{J} 1$ drain on November 11,1988 . The water was primarily a calcium bicarbonate sulfate type with a selenium concentration of $7 \mu \mathrm{g} / \mathrm{L}$. Although the selenium concentration was within the typical range of water from the $\mathrm{J} 1$ drain, the water in the drain was a calcium sulfate type with a small quantity of bicarbonate. The difference in water type suggests drainwater may have had more contact with gypsum than did the seepage, either through a longer flow path or exposure to soils containing more gypsum.

\section{Trends in Discharge, Specific Conductance, and Selenium Concentration in Drainwater Entering Stewart Lake}

Seasonal variations in flow and specific conductance for each of the drains discharging to Stewart Lake for the period from drain completion to October 1989 are shown in figures 21 to 24 . Discharge typically was smallest during the early spring and increased in response to application of irrigation water in late April. Discharge was large during the irrigation months of May, June, July, and August, and declined during September after irrigation was discontinued. Discharge did not show any trends from year to year. Discharge from the drains during the abnormally wet years of 1984-87 did not appear larger than for the drier years of 1988-89. Because the agricultural land relies primarily on irrigation rather than precipitation to supply water, any increase or decrease in precipitation is a minor part of the total water applied to the land. Determination of trends in discharge and constituents was adversely affected by the relatively few data for 1986-87. Additionally, the outlet structure at Stewart Lake has been undercut, and an unknown but small volume of water bypasses the outlet weir.

Because most of the drains have been in operation about 10 years, readily leachable salts and trace elements have been removed from at least some of the area. Degradation of the shale, however, is a constant process, continually releasing salts into the drainage area. If salt is removed by the drainwater faster than it is supplied by degradation, then concentrations of salts in the drainwater 
Table 3. Median discharges, median concentrations of selenium and chloride, and loads of selenium and chloride in drainwater entering Stewart Lake and in the outflow from the lake

$\left[\mathrm{ft}^{3} / \mathrm{s}\right.$, cubic feet per second; mg/L, milligrams per liter; $\mathrm{kg} /$ day, kilograms per day; $\mu \mathrm{g} / \mathrm{L}$, micrograms per liter; g/day, grams per day. Discharge for outflow and all concentration data are for water years 1988-89. Discharges for drains are for the period of record]

\begin{tabular}{lccccc}
\hline \multicolumn{1}{c}{ Site } & $\begin{array}{c}\text { Median } \\
\text { discharge } \\
\left(\mathrm{ft}^{3} / \mathrm{s}\right)\end{array}$ & $\begin{array}{c}\text { Median chloride } \\
\text { concentration } \\
(\mathrm{mg} / \mathrm{L})\end{array}$ & $\begin{array}{c}\text { Chloride } \\
\text { load } \\
(\mathrm{kg} / \mathrm{day})\end{array}$ & $\begin{array}{c}\text { Median selenium } \\
\text { concentration } \\
(\mu \mathrm{g} / \mathrm{L})\end{array}$ & $\begin{array}{c}\text { Selenium } \\
\text { load } \\
(\mathrm{g} / \text { day })\end{array}$ \\
\hline Drain J1 & 10.99 & 235 & 84.79 & 230.5 & 73.89 \\
Drain J2 & .78 & 28 & 53.44 & 34 & 64.89 \\
Drain J3 & .4 & 68.5 & 67.06 & 77 & 75.38 \\
Drain J4 & .21 & 96.5 & $\underline{49.61}$ & 74 & 38.04 \\
Total inflow load & & & 254.9 & & 252.2 \\
\hline Outflow & 4.9 & & & 5 & 60 \\
\end{tabular}

\footnotetext{
${ }^{1}$ Discharge is combined for the $\mathrm{J} 1$ and J1A drains.

${ }^{2}$ Concentration is for the $\mathrm{J} 1$ drain.
}

should decrease with time. Conversely, if weathering releases quantities of salts equal to or exceeding those removed by the drains, concentrations in the water will show no trend or will tend to increase. Conductivity data were available from monitoring done by the USBOR starting upon completion of each drain (1979-81) and continuing until 1986. Data from 1986 to 1989 were collected by the USGS. Definite decreases in the conductivity of water from drains J2 and J3, a possible decrease in J4, and no trend in $\mathrm{J} 1$ are shown in figures 21 to 24 . There was an insignificant relation between specific conductance and discharge, although specific conductance generally increased during the summer months. There did not appear to be any long-term trend in discharge at any site.

The seasonal-Kendall test for trend (Hirsch and others, 1982) was used to determine if trends in specific conductance were statistically significant and to determine the magnitude of change. For many water-quality constituents discharge provides dilution, and a trend of changing discharge may produce a trend in concentrations. Usually concentration data are flow adjusted to remove the effects of discharge prior to analysis for trends. Because of the lack of relation between discharge and specific conductance for water from the drains and because of the lack of any trend in discharge, flow adjustment was not done prior to trend analysis of the conductivity data. The seasonal-Kendall test showed a substantial decline in conductivity for drains J2 and J3 and no significant trend for drains $\mathrm{J} 1$ and $\mathrm{J} 4$ (table 4). While the median specific conductance of $3,630 \mu \mathrm{S} / \mathrm{cm}$ for water from drain $\mathrm{J} 3$ was nearly 50 percent larger than the median of $2,457 \mu \mathrm{S} / \mathrm{cm}$ for drain $\mathrm{J} 2$, the rate of decline in specific conductance for drain J3 was 3 times greater than at drain J2.

The decline in conductivity of water in drains J2 and J3 with time suggests these drains are protected by drains $\mathrm{J} 1$ and $\mathrm{J} 4$ acting as "guard drains". This is a technique used in drainage design to minimize outside influence and provide a streamline path for flow toward drains on the interior of a grid. The outer drains (J1 and J4) are subjected to a much larger area of influence. Depending on the gradient, hydraulic conductivity, and depth to barrier zone, the outer drains could be influencing water flow to a distance of four times greater than the inner drains influence the flow (R. Tekrony, U.S. 


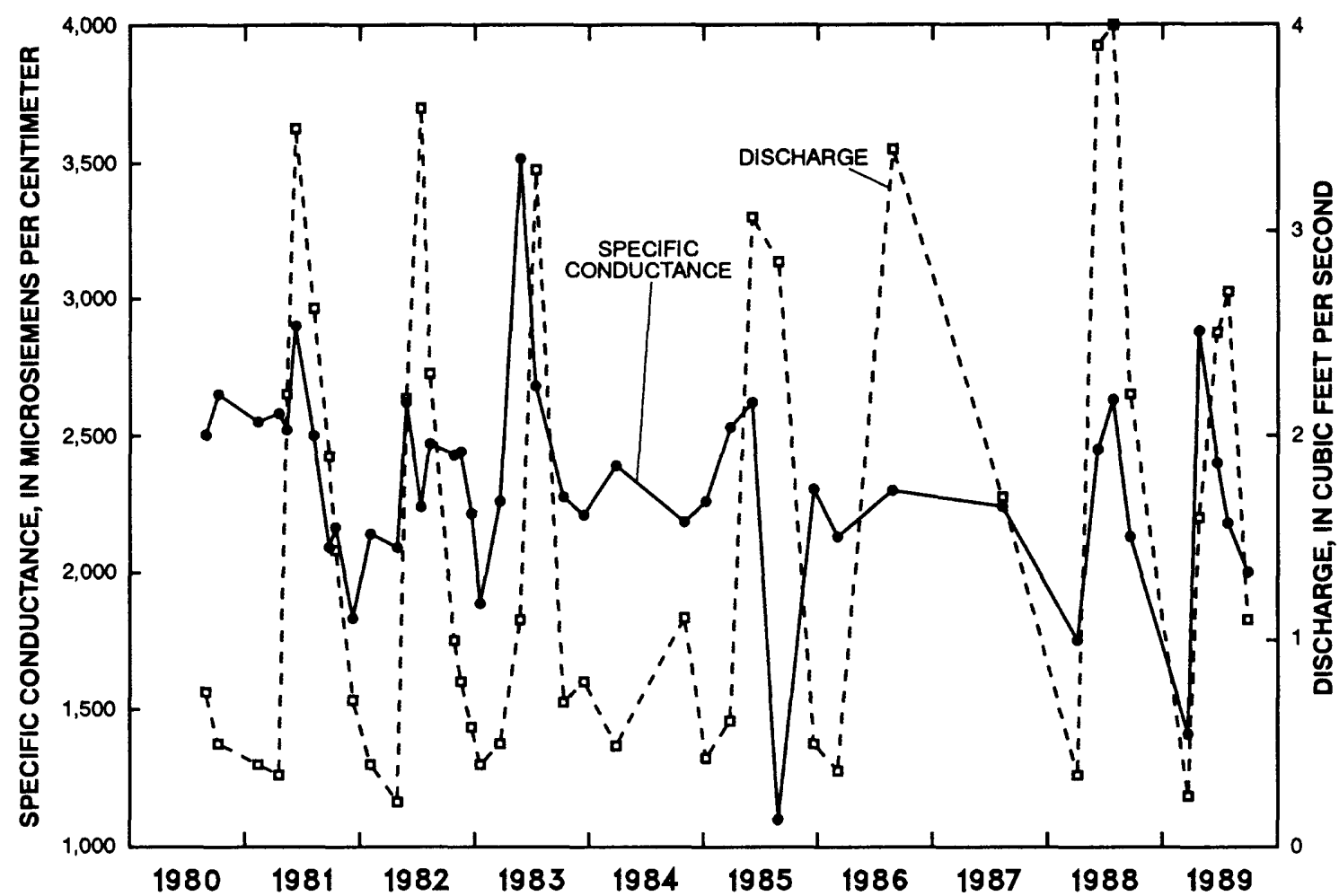

Figure 21. Specific conductance and discharge for water entering Stewart Lake from the combined flows of the $\mathrm{J} 1$ and $\mathrm{J} 1 \mathrm{~A}$ drains.

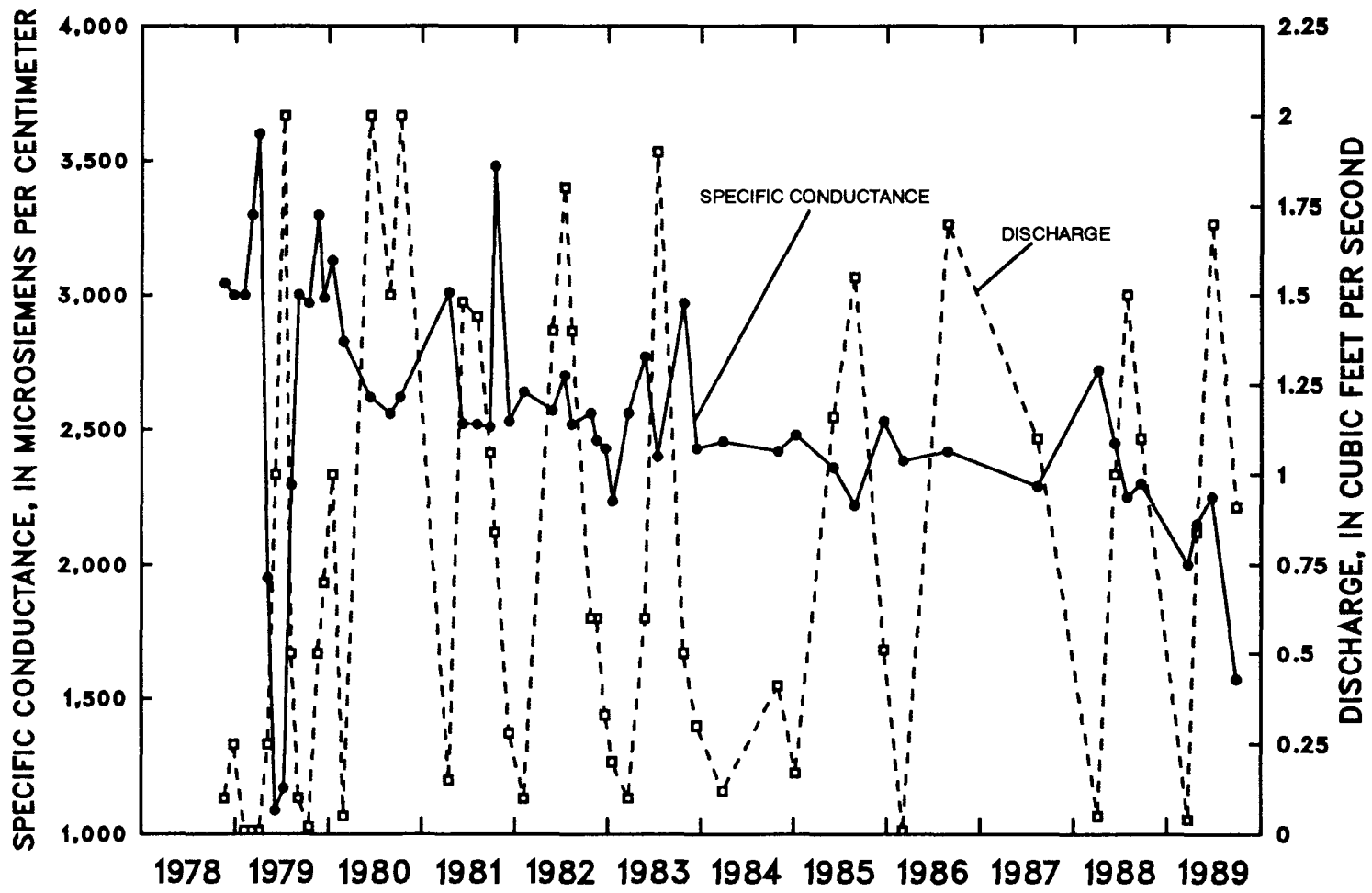

Figure 22. Specific conductance and discharge for water entering Stewart Lake from the J2 drain. 


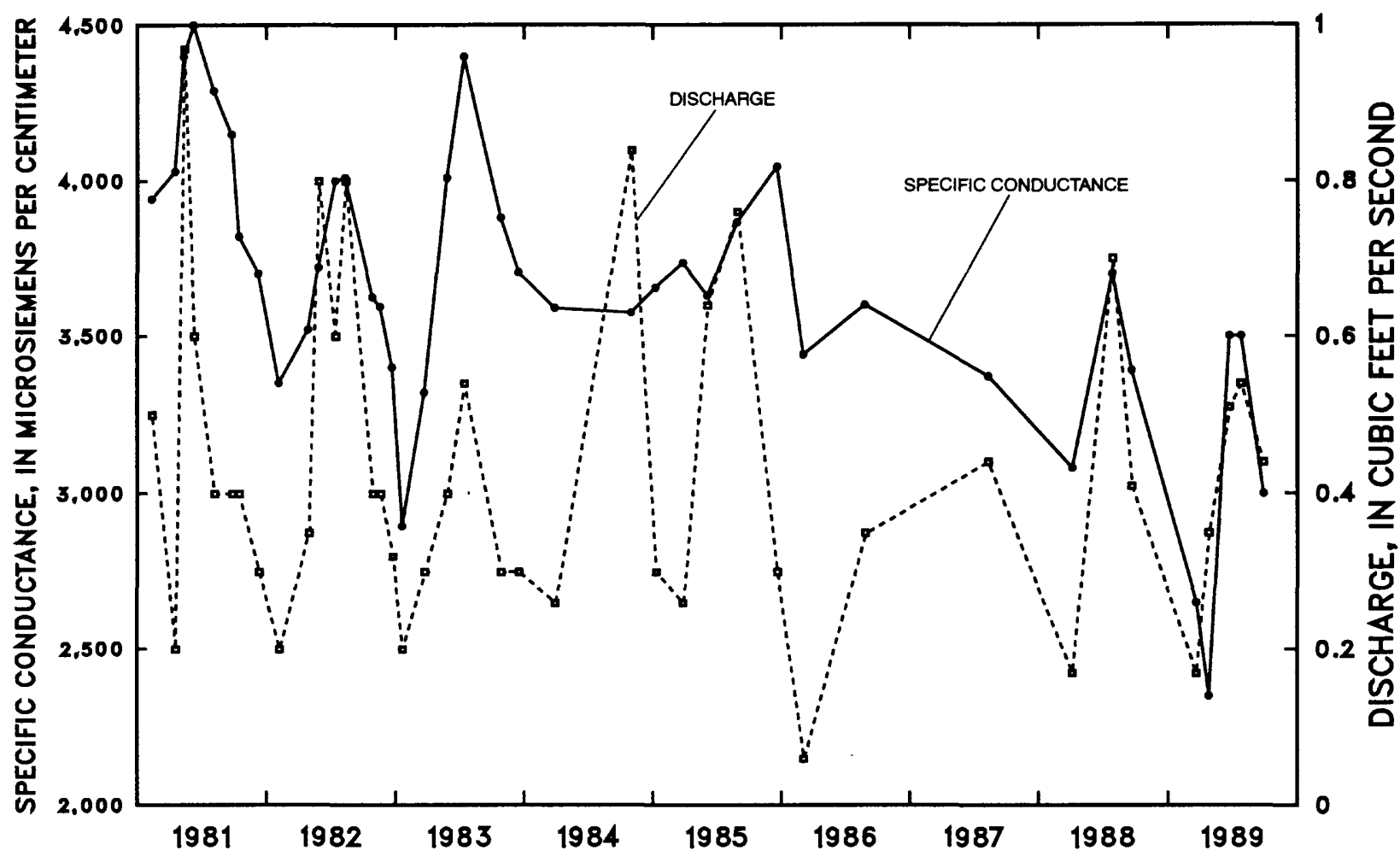

Figure 23. Specific conductance and discharge for water entering Stewart Lake from the J3 drain.

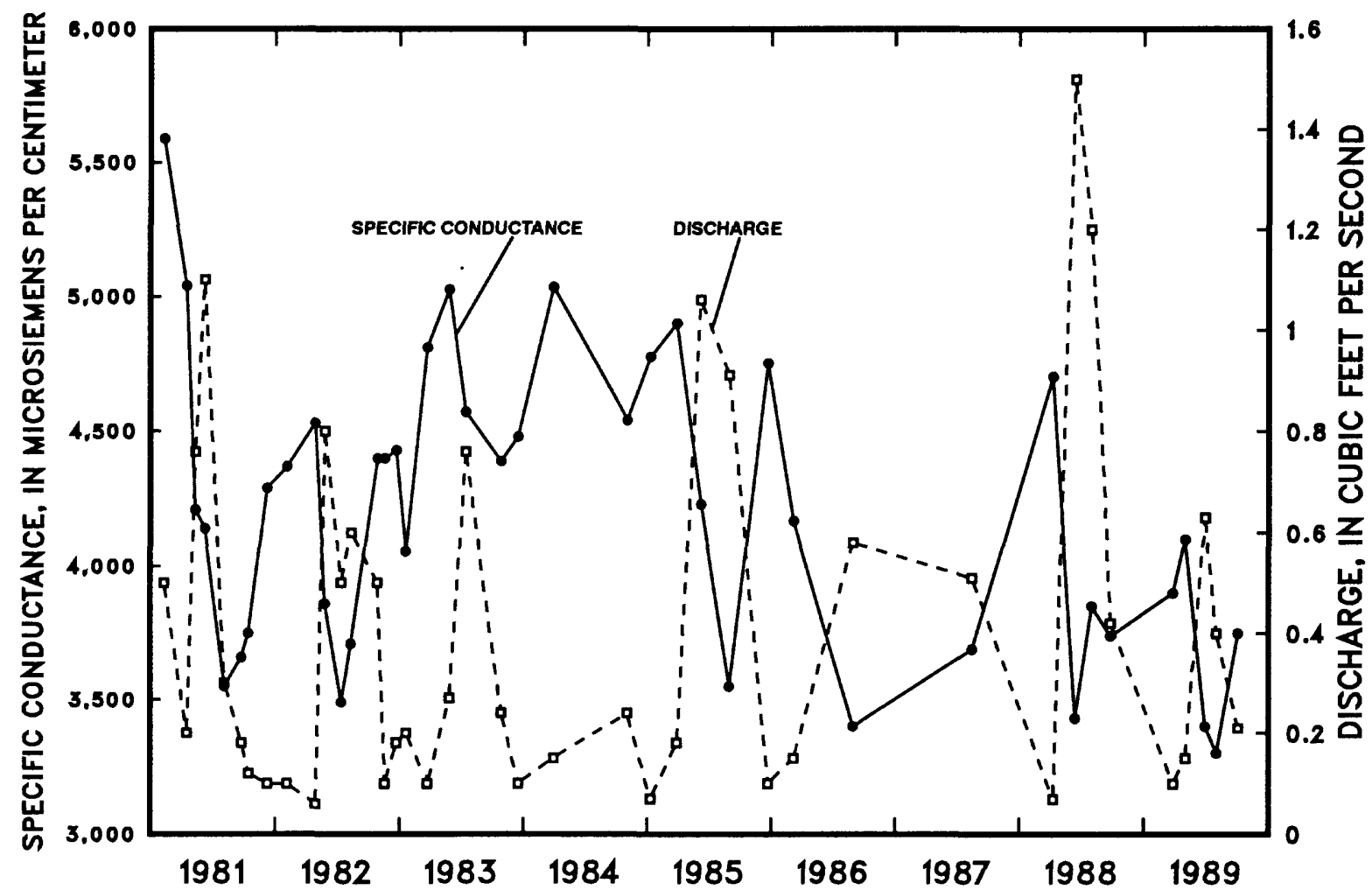

Figure 24. Specific conductance and discharge for water entering Stewart Lake from the J4 drain. 
Bureau of Reclamation, written commun., 1991). For this reason, a much longer period of time would be required before a decrease in conductivity would occur in drains $\mathrm{J} 1$ and $\mathrm{J} 4$.

Because of the lack of data on dissolved-selenium concentrations in drainwater prior to 1986, the relation between specific conductance and selenium in water from each drain was used to determine if selenium concentrations have increased or decreased in drainwater discharged to Stewart Lake. Linear regression of selenium and conductivity data from each drain during 1986-89 was used to predict pre-1986 selenium concentrations in water from each of the drains. Coefficients of determination for the regressions ranged from 0.35 for drain $\mathrm{J} 4$ to 0.91 for drain $\mathrm{J} 1$. The measured and predicted selenium concentrations for water in each drain are shown in figures 25 to 28 . The trend towards declining values for specific conductance of water from drains J2 and J3 noted earlier occurred also for selenium. There appeared to be no trend for drains $\mathrm{J} 1$ and $\mathrm{J} 4$.

Table 4. Results of the seasonal-Kendall test for trends in discharge and specific conductance for drains discharging to Stewart Lake

[ $\mu \mathrm{S}$, microsiemens; $\mathrm{S}$, significant $(0.01<\mathrm{p}<0.05)$; NS, not significant $(\mathrm{p}>0.1)]$

\begin{tabular}{|c|c|c|c|c|c|}
\hline \multirow[b]{2}{*}{ Drain } & \multirow{2}{*}{$\begin{array}{c}\text { Period of record } \\
\text { (water year) }\end{array}$} & \multicolumn{2}{|c|}{ Discharge } & \multicolumn{2}{|c|}{ Specific conductance } \\
\hline & & Significance & Trend & Significance & Trend \\
\hline 1J1 & $1980-89$ & NS & none & NS & none \\
\hline J2 & $1979-89$ & NS & none & $\mathrm{S}$ & $-43 \mu \mathrm{S} /$ year \\
\hline J3 & $1981-89$ & NS & none & S & $-128 \mu \mathrm{S} /$ year \\
\hline $\mathrm{J} 4$ & $1981-89$ & NS & none & NS & none \\
\hline
\end{tabular}

\footnotetext{
${ }^{1}$ Discharge is combined flow of drains $\mathrm{J} 1$ and J1A; specific conductance of combined flow prior to August 26,1986, and J1 only subsequent to that date.
}

In aerobic water, selenium is transported primarily in selenite $\left(\mathrm{H}_{2} \mathrm{SeO}_{3},+4\right.$ oxidation), selenate $\left(\mathrm{H}_{2} \mathrm{SeO}_{4},+6\right.$ oxidation), or a reduced or organic form (- 2 oxidation). While most forms of selenium are toxic to wildlife, selenite is usually more toxic to early life stages (Eisler, 1985, p. 30). Selenite forms insoluble salts, adsorbs to ferric oxides, and is easily reduced to insoluble elemental selenium by mild reducing agents (Callahan and others, 1979, p. 16-4); therefore, the selenite form is not prevalent in most aerobic water having an alkaline $\mathrm{pH}$. The speciation of selenium in drainwater was not directly determined during this study; however, drainwater discharged to Stewart Lake was analyzed for selenium by the Utah State Health Department from 1978 to 1986 using the hydride generation-atomic absorption method without an oxidation-reduction digestion. This procedure determines selenite concentration only. The maximum selenite concentration determined in 284 unfiltered samples of water was $2.3 \mu \mathrm{g} / \mathrm{L}$, and most samples contained less than $1 \mu \mathrm{g} / \mathrm{L}$, which indicates that virtually all selenium in the drainwater is present as selenate or in an organic form.

\section{Uranium and Alpha Radiation in Water in the Jensen Area}

Stephens and others (1988a, p. 44) reported that uranium concentrations in some drainwater entering Stewart Lake and in marsh 4720 exceeded the National Academy of Sciences recommended maximum of $35 \mu \mathrm{g} / \mathrm{L}$ for drinking water, and gross alpha radiation exceeded the Utah standard of 15 


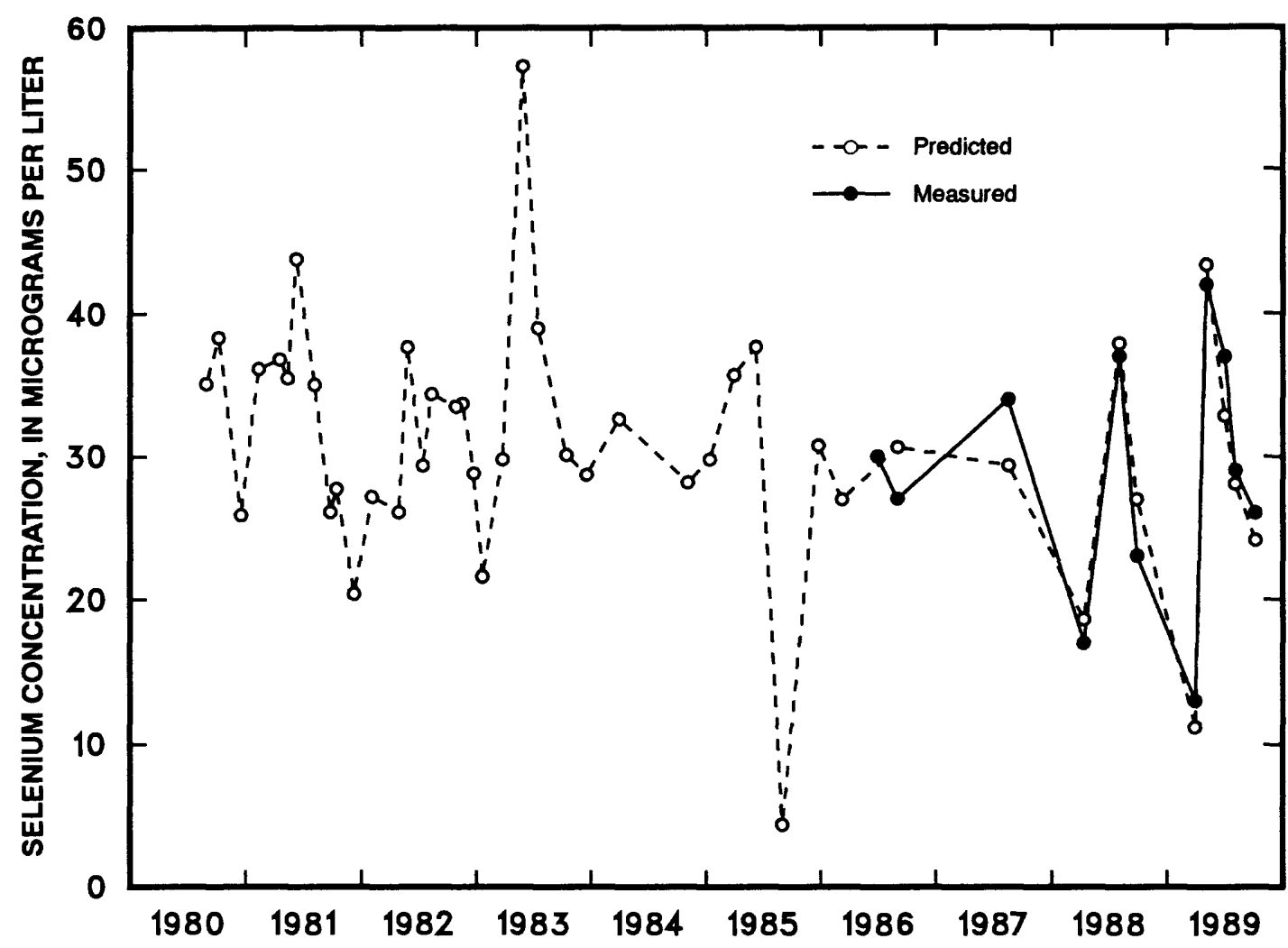

Figure 25. Predicted and measured selenium concentrations discharged to Stewart Lake from the J1 drain, 1980-89.

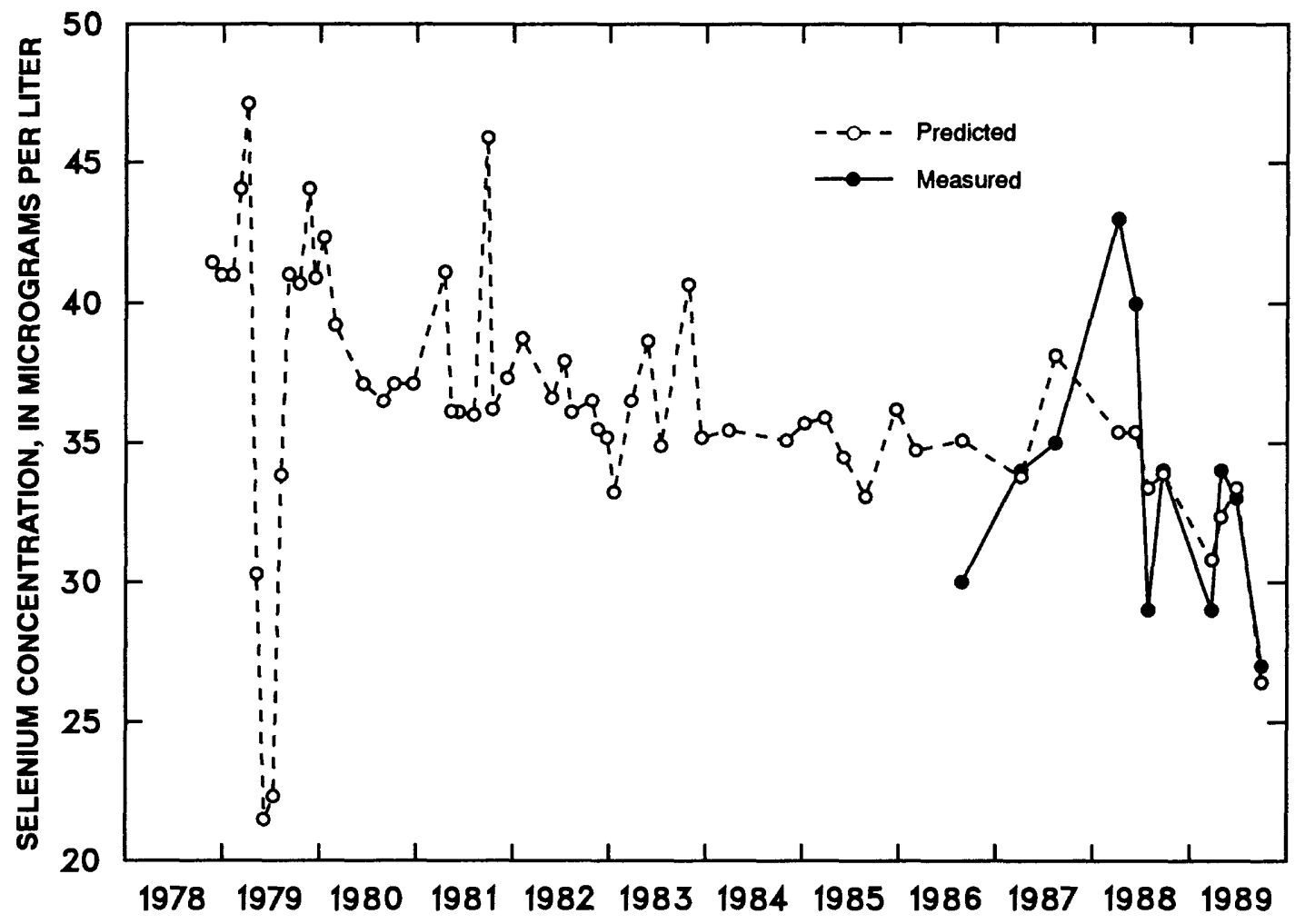

Figure 26. Predicted and measured selenium concentrations discharged to Stewart Lake from the J2 drain, 1978-89. 


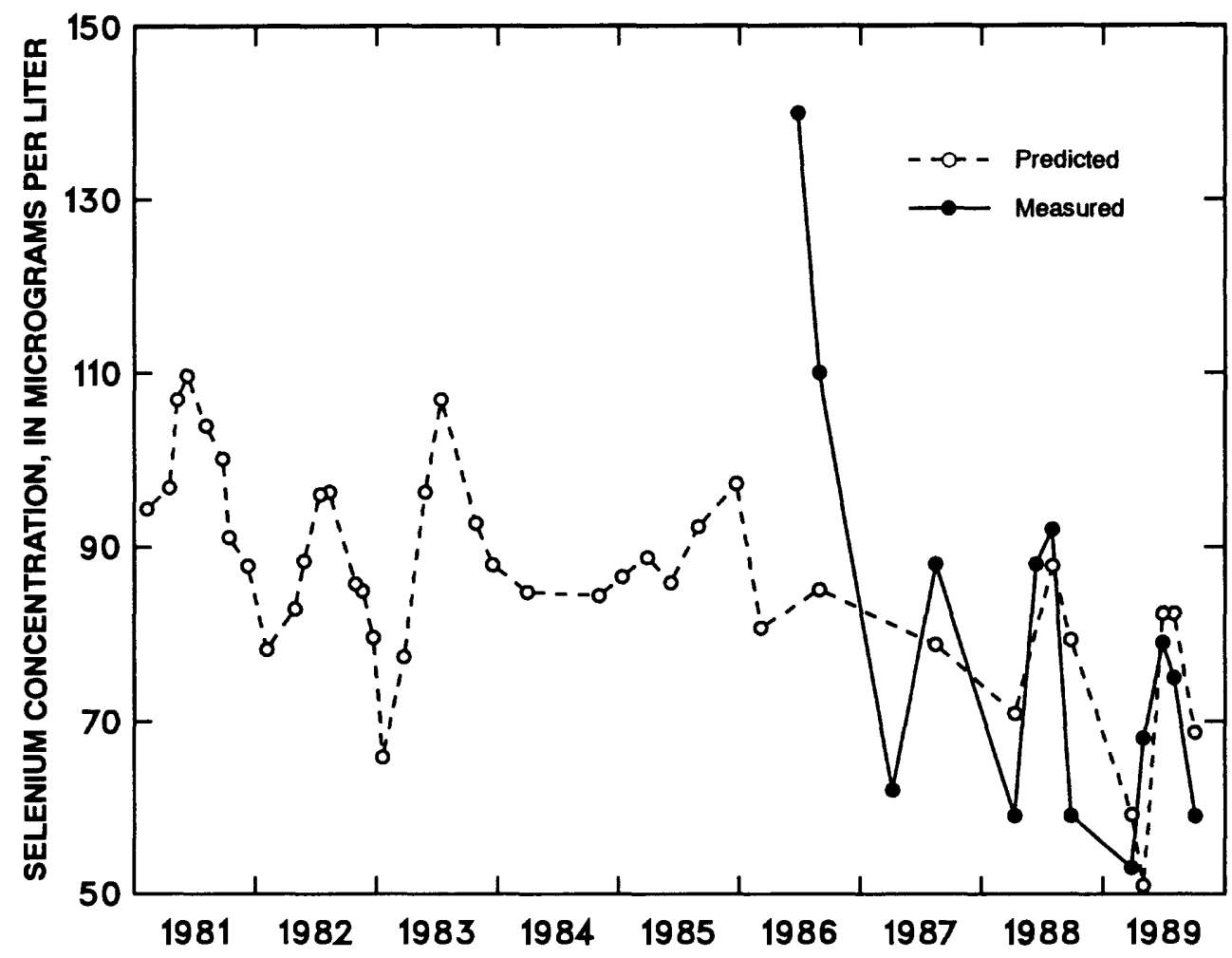

Figure 27. Predicted and measured selenium concentrations discharged to Stewart Lake from the J3 drain, 1981-89.

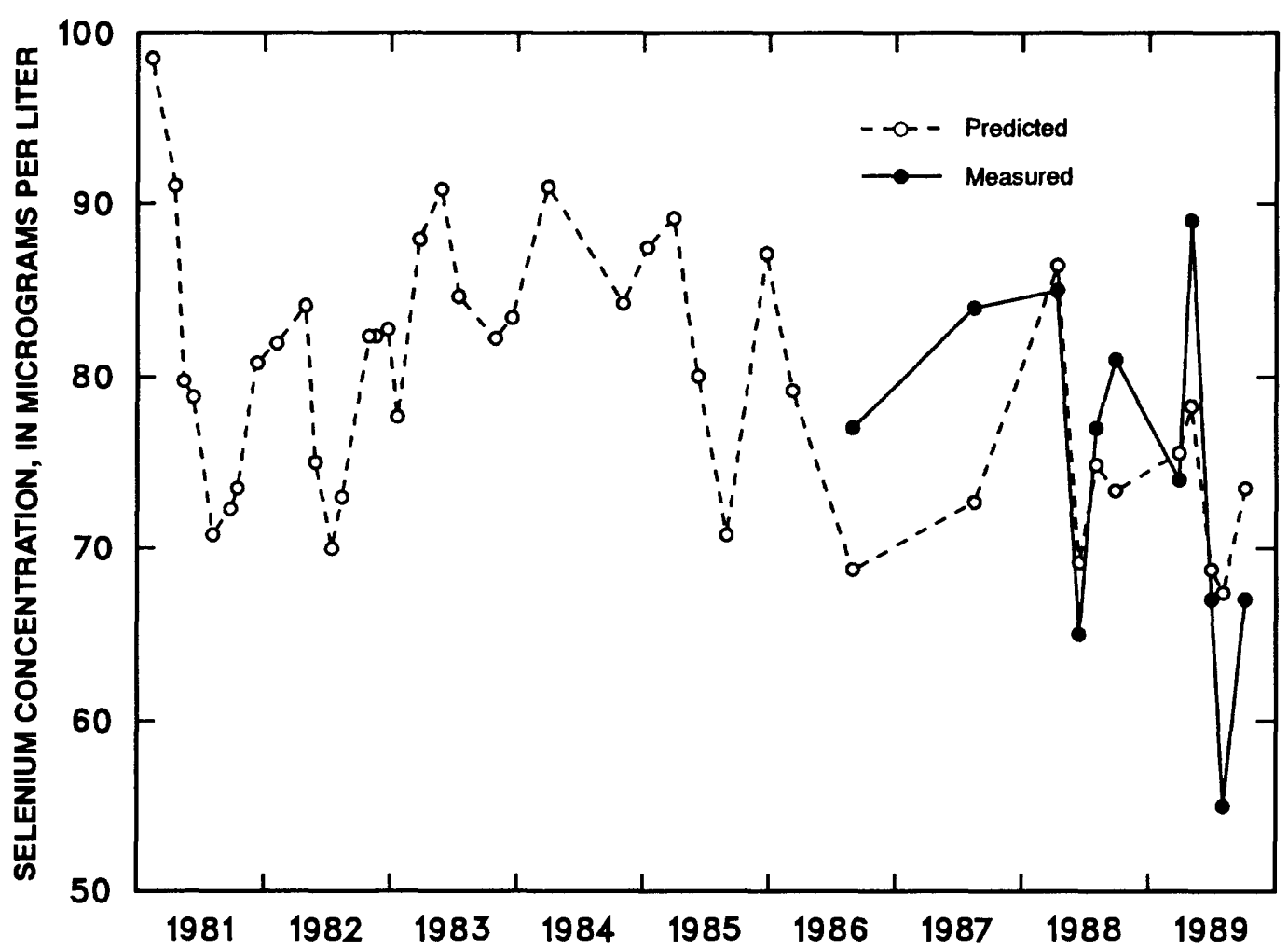

Figure 28. Predicted and measured selenium concentrations discharged to Stewart Lake from the J4 drain, 1981-89. 
pCi/L for wildlife protection. Summary statistics for gross alpha radiation in water associated with Stewart Lake and lower Ashley Creek are given as follows:

\begin{tabular}{lcccccc}
\hline & $\begin{array}{c}\text { Drains J1 } \\
\text { and J1A }\end{array}$ & Drain J2 & Drain J3 & Drain J4 & $\begin{array}{c}\text { Stewart } \\
\text { Outflow }\end{array}$ & $\begin{array}{c}\text { Ashley Creek } \\
\text { (2 sites) }\end{array}$ \\
\hline $\begin{array}{l}\text { Number of samples } \\
\text { Gross alpha range } \\
(\mathrm{pCi} / \mathrm{L})\end{array}$ & 4 & 2 & 3 & 3 & 3 & 3 \\
\hline
\end{tabular}

On the basis of a small number of samples, drainwater from the combined flow of the $\mathrm{J} 1$ and J1A drains and the outflow from Stewart Lake on only one occasion exceeded the maximum State standard for the protection of aquatic wildlife. Drainwater from the J2, J3, and J4 drains exceeded the maximum standard in every sample. A single sample from Ashley Creek at the point of discharge to the Green River was nearly twice as large $(29 \mathrm{pCi} / \mathrm{L})$ as permissible.

Although much has been written on the uptake and effects of gamma radiation on wild and domestic animals, there is little information available on the effects of the weaker alpha radiation. Generally, unless ingested or inhaled, alpha radiation is not damaging to organisms.

\section{Selenium in Bottom Sediment from Stewart Lake}

Periodic draining of water and movement of sediment commonly is used in management of waterfowl areas. Dredging activities could result in oxidation of reduced forms of selenium in the sediment and subsequent remobilization of selenate upon flooding. The effect of dewatering sediment from Stewart Lake by drying and then reflooding was investigated using isolated core samples. Two cores, each about $30 \mathrm{~cm}$ in length were collected near the outlet from the lake. The selenium concentration in the surface sediment of an adjacent core was $7 \mu \mathrm{g} / \mathrm{g}$. The cores were allowed to air dry in the laboratory in the core tubes for 6 weeks. Organic layers near the top of the cores changed from black to tan over the drying and aeration period. The cores were rehydrated with water that was collected from the Green River immediately upstream of Stewart Lake and had a selenium concentration of $3 \mu \mathrm{g} / \mathrm{L}$. At the time of hydration, the $\mathrm{pH}$ of water over the cores was 8.2 and the redox potential was +113 millivolts. Within 0.7 hour, the selenium concentration in water overlying both cores had doubled to 6 and $7 \mu \mathrm{g} / \mathrm{L}$. The concentrations in the overlying water were sampled four more times over 189 hours. The selenium concentration of water in one core remained near 7 or $8 \mu \mathrm{g} / \mathrm{L}$ throughout the experiment. Selenium concentrations in water in the second core increased to $17 \mu \mathrm{g} / \mathrm{L}$ within 18 hours but declined to $14 \mu \mathrm{g} / \mathrm{L}$ by 189 hours. At the termination of the experiment, the $\mathrm{pH}$ of water in the core showing the greatest change was 7.8 and the redox potential +112 millivolts. No measurements were done on the other core. These results indicated that lake sediment containing even small selenium concentrations, once removed from anaerobic and reducing conditions, can quickly release significant quantities of selenium into the water column upon rehydration.

\section{Selenium in Soil from the Jensen Area}

Prior to irrigating previously unirrigated land, the USBOR is now required by their agency to determine the potential for release of toxic substances from the irrigated soils. The Jensen soilextraction study was designed, in part, to aid in the establishment of criteria to evaluate such test data. In addition, the soil study was designed to determine selenium distribution patterns in the soils, both vertically and horizontally; feasibility of modeling a leach-out rate; and establish if a correlation existed between selenium concentrations in the soil and concentrations in drainwater from those soils. A further objective was to determine if 1:10 (soil:water) extractions could be used to replace saturation extractions, which are more difficult to perform. 


\section{Association of total selenium in soil and water-extractable selenium}

Concentrations of total-extractable selenium ranged from 200 to $3,000 \mu \mathrm{g} / \mathrm{kg}$ from irrigated soils in the Jensen area (table 5). Typically less than 5 percent of the total selenium in the soils was removed by saturation-extraction methods. The greatest recovery was for a sample of efflorescence in which all selenium was likely present as readily soluble selenate. The mean concentration of total selenium in 40 samples of irrigated soils from areas with drains was $915 \mu \mathrm{g} / \mathrm{kg}$, a value not significantly different from the mean of $850 \mu \mathrm{g} / \mathrm{kg}$ for 4 samples of irrigated soils in areas without drains.

There were weak correlations between concentrations of total selenium in soils and concentrations of selenium in 1:10 deionized-water extracts, saturated deionized water extracts, and saturated native-water extracts (fig. 29). In addition, there was a weak correlation between selenium concentrations in soil and concentrations in drainwater sampled from access points in drains adjacent to the soils. In contrast to observations by Laronne (1977b, p. 74), no correlation was found between concentrations of extractable salts and depth from which the soil was sampled. The coefficient of determination $\left(R^{2}\right)$ was 0.78 between the specific conductance of saturation extracts and the specific conductance of $1: 10$ extracts.

There were moderately large selenium concentrations in samples of Mancos Shale and areas of salt efflorescence; however, the quantity of selenium in the shale that was extracted by water was quite variable. Two samples of Mancos Shale from the Jensen and Vernal areas yielded 4 to 31 percent of the total selenium content to saturation extracts (table 5). Typically, water-soluble selenium represents about 2 to 10 percent of total selenium present in soils (Berrow and Ure, 1989, p. 230).

A single sample of surface efflorescence was taken from a soil derived from Mancos Shale downgradient from an area of canal leakage. The saturation extraction from this sample yielded 2,300 $\mu \mathrm{g} / \mathrm{L}$ of selenium, believed to be predominantly selenate because the yield was about 75 percent of the total soil selenium from the split soil sample. This site is adjacent to the J4 drain that often had the largest concentrations of dissolved selenium of all drains in the area, which suggests that at least some of the selenium found in pore water extracted from the soils and in the drainwater may be transported from shallow ground-water sources such as canal leakage coming in direct contact with Mancos Shale.

The form and solubility of selenium in the various extractions may have been altered between time of sampling and analysis. The soluble forms of selenium that are present in the pore water in a soil dried prior to extraction should re-dissolve upon hydration; however, drying the samples may have resulted in mineral reformation to less soluble forms.

The water extractions did not always reach the same $\mathrm{pH}$ present in the pore-water extracts and were often less than those of the pore water. The $\mathrm{pH}$ of the deionized water used for extraction was 5.5 to 6.0 , resulting in deionized water $1: 10$ extracts with a $\mathrm{pH}$ range of 6.2 to 7.5 , and the saturation extracts and the native water ranged from 6.3 to 8.4 (table 5). Since $\mathrm{pH}$ is important to the solubility of the various forms of selenium, a pH-buffered extraction fluid may have produced better results. In particular, the 1:10 extractions may have been adversely affected by the intial $\mathrm{pH}$. On the other hand, the saturation extraction appears to have been adequately buffered by the soil sample (table 6), because the $\mathrm{pH}$ of the native fluid approximated the $\mathrm{pH}$ of the saturation extract fluid in most samples. The $\mathrm{pH}$ of the saturation extracts was consistently larger than the $\mathrm{pH}$ of the 1:10 extracts.

The oxidation state of the soils from Jensen was not measured, but during extraction, soils were aerobic and expected to have moderate oxidation potentials. Under strongly oxidizing conditions (450 millivolts) and within a pH range of 6.5 to 7.5, Masscheleyn and others $(1990, \mathrm{p} .96)$ reported that 75 percent of the total selenium in some soils was present as readily solubilized selenate; however, as the oxidation potential declined to 200 millivolts, the major part of the total selenium (60-78 percent) was present in the more readily adsorbed form of selenite. No speciation of selenium was determined in the extracts of Jensen soils. Oxidation could have occurred in the soil samples during transport and sample handling, and the $\mathrm{pH}$ could have changed after removal from the ground. 
Table 5. Selenium concentrations in drainwater and soil, and selenium concentrations and values of specific conductance and $p H$ in extracts of soil, Mancos Shale, and salt efflorescence in the area of Jensen, Utah

$[\mu \mathrm{g} / \mathrm{L}$, micrograms per liter; $\mu \mathrm{g} / \mathrm{kg}$, micrograms per kilogram; $\mu \mathrm{S} / \mathrm{cm}$, microsiemens per centimeter; $\mathbf{M}$, middle of drain line; $\mathrm{B}$, bottom of drain line near outlet; $\mathrm{T}$, top of drain line; $\mathrm{VSL}^{\mathrm{I}}$, site near Vernal sewage lagoons; -, not determined]

\begin{tabular}{|c|c|c|c|c|c|c|c|c|c|c|c|}
\hline \multirow[b]{2}{*}{$\begin{array}{c}\text { Site } \\
\text { number } \\
\text { (fig. 6) }\end{array}$} & \multirow[b]{2}{*}{ Drain } & \multirow[b]{2}{*}{$\begin{array}{c}\text { Sample } \\
\text { depth } \\
\text { (feet) }\end{array}$} & \multirow[b]{2}{*}{$\begin{array}{l}\text { Satur- } \\
\text { ation } \\
\text { moisture } \\
\text { (percent) }\end{array}$} & \multicolumn{4}{|c|}{ Selenium concentration } & \multicolumn{2}{|c|}{ Conductivity } & \multicolumn{2}{|c|}{$\mathbf{p H}$} \\
\hline & & & & $\begin{array}{l}\text { Drain- } \\
\text { water } \\
(\mu \mathrm{g} / \mathrm{L})\end{array}$ & $\underset{(\mu \mathrm{g} / \mathrm{kg})}{\text { Soil }}$ & $\begin{array}{l}\text { Satur- } \\
\text { ation } \\
\text { extract } \\
(\mu \mathrm{g} / \mathrm{L})\end{array}$ & $\begin{array}{l}1: 10 \\
\text { extract } \\
(\mu \mathrm{g} / \mathrm{L})\end{array}$ & $\begin{array}{l}\text { Satur- } \\
\text { ation } \\
\text { extract } \\
(\mu \mathrm{S} / \mathrm{cm})\end{array}$ & $\begin{array}{c}1: 10 \\
\text { extract } \\
(\mu \mathrm{S} / \mathrm{cm})\end{array}$ & $\begin{array}{l}\text { Satur- } \\
\text { ation } \\
\text { extract } \\
\text { (units) }\end{array}$ & $\begin{array}{c}1: 10 \\
\text { extract } \\
\text { (units) }\end{array}$ \\
\hline \multicolumn{12}{|c|}{ Irrigated and drained soil } \\
\hline \multirow[t]{3}{*}{13} & J1-M & $0-3$ & 55.2 & $30-40$ & 1,200 & 21 & 4 & 4,790 & 605 & 8.1 & 7.4 \\
\hline & J1-M & $3-5$ & 37.2 & & 1,000 & 53 & 6 & 6,820 & 1,990 & 7.9 & 7.1 \\
\hline & J1-M & $5-6.2$ & 38.3 & & 1,100 & 50 & 9 & 6,600 & 891 & 7.2 & 6.9 \\
\hline \multirow[t]{3}{*}{15} & J1-B & $0-3$ & 26.7 & $30-40$ & 3,000 & 5 & 7 & 5,720 & 97 & 8.3 & 6.5 \\
\hline & J1-B & $3-6$ & 20.9 & & 300 & 6 & 3 & 451 & 62 & 7.9 & 6.7 \\
\hline & J1-B & $6-9$ & 25.4 & & 200 & 2 & $<1$ & 308 & 45 & 7.6 & 5.7 \\
\hline \multirow[t]{3}{*}{11} & J2-T & $0-3$ & 50.7 & 60 & 900 & 15 & 2 & 1,210 & 182 & 7.8 & 6.7 \\
\hline & J2-T & $3-6$ & 27.8 & & 200 & 19 & 1 & 1,540 & 133 & 7.9 & 6.9 \\
\hline & J2-T & $6-9$ & 21.9 & & 200 & 8 & 1 & 704 & 79 & 8.1 & 6.7 \\
\hline \multirow[t]{3}{*}{12} & J2-T & $0-3$ & 51.4 & $20-40$ & 1,100 & 180 & 16 & 10,600 & 1,510 & 7.8 & 7.6 \\
\hline & J2-T & $3-6$ & 51.3 & & 1,700 & 320 & 25 & 12,500 & 2,810 & 7.6 & 7.7 \\
\hline & J2-T & $6-9$ & 38.7 & & 1,200 & 170 & 11 & 6,270 & 1,230 & 7.9 & 6.5 \\
\hline \multirow[t]{3}{*}{2} & J3-M & $1-4$ & 30.5 & $20-90$ & 400 & 6 & 1 & 769 & 24 & 8.0 & 7.0 \\
\hline & J3-M & $4-5.5$ & 32.9 & & 500 & 29 & 3 & 4,020 & 303 & 7.5 & 7.1 \\
\hline & J3-M & $5.5-7$ & 47.7 & & 500 & 26 & 3 & 2,040 & 242 & 7.8 & 7.5 \\
\hline \multirow[t]{3}{*}{1} & J3-B & $1-4$ & 31.7 & $70-90$ & 500 & 38 & 4 & 5,170 & 1,140 & 8.1 & 6.3 \\
\hline & J3-B & 4-6.5 & 26.5 & & 200 & 3 & $<1$ & 1,870 & 110 & 7.6 & 6.6 \\
\hline & J3-B & $6.5-6.8$ & 28.3 & & 200 & 8 & 1 & 2,420 & 131 & 6.7 & 5.8 \\
\hline \multirow[t]{3}{*}{3} & J4-T & $2-5$ & 58.3 & $20-40$ & 1,500 & 27 & 4 & 4,900 & 1,030 & 7.7 & 6.6 \\
\hline & J4-T & $5-7$ & 58.9 & & 1,200 & 38 & 5 & 3,960 & 561 & 7.3 & 6.7 \\
\hline & J4-T & $7-9$ & 58 & & 1,200 & 9 & 2 & 2,440 & 347 & 8.0 & 6.8 \\
\hline \multirow[t]{3}{*}{5} & J4-M & $0-2$ & 43.7 & $50-60$ & 1,200 & 54 & 7 & 3,520 & 682 & 8.4 & 7.4 \\
\hline & J4-M & $2-5$ & 42.6 & & 1,100 & 350 & 22 & 4,840 & 561 & 8.0 & 7.1 \\
\hline & J4-M & $5-7$ & 54 & & 1,200 & 170 & 14 & 3,190 & 363 & 7.8 & 7.0 \\
\hline
\end{tabular}


Table 5.-Selenium concentrations in drainwater and soil, and selenium concentrations and values of specific conductance and $\mathrm{pH}$ in extracts of soil, Mancos Shale, and salt efflorescence in the area of Jensen, Utah-Continued

\begin{tabular}{|c|c|c|c|c|c|c|c|c|c|c|c|}
\hline \multirow[b]{2}{*}{$\begin{array}{c}\text { Site } \\
\text { number } \\
\text { (fig. 6) }\end{array}$} & \multirow[b]{2}{*}{ Drain } & \multirow[b]{2}{*}{$\begin{array}{c}\text { Sample } \\
\text { depth } \\
\text { (feet) }\end{array}$} & \multirow[b]{2}{*}{$\begin{array}{l}\text { Satur- } \\
\text { ation } \\
\text { moisture } \\
\text { (percent) }\end{array}$} & \multicolumn{4}{|c|}{ Selenium concentration } & \multicolumn{2}{|c|}{ Conductivity } & \multicolumn{2}{|c|}{$\mathbf{p H}$} \\
\hline & & & & $\begin{array}{l}\text { Drain- } \\
\text { water } \\
(\mu \mathrm{g} / \mathrm{L})\end{array}$ & $\begin{array}{c}\text { Soil } \\
(\mu \mathrm{g} / \mathrm{kg})\end{array}$ & $\begin{array}{l}\text { Satur- } \\
\text { ation } \\
\text { extract } \\
(\mu \mathrm{g} / \mathrm{L})\end{array}$ & $\begin{array}{l}1: 10 \\
\text { extract } \\
(\mu g / L)\end{array}$ & $\begin{array}{l}\text { Satur- } \\
\text { ation } \\
\text { extract } \\
(\mu \mathrm{S} / \mathrm{cm})\end{array}$ & $\begin{array}{c}1: 10 \\
\text { extract } \\
(\mu \mathrm{S} / \mathrm{cm})\end{array}$ & $\begin{array}{l}\text { Satur- } \\
\text { ation } \\
\text { extract } \\
\text { (units) }\end{array}$ & $\begin{array}{c}1: 10 \\
\text { extract } \\
\text { (units) }\end{array}$ \\
\hline \multicolumn{12}{|c|}{ Irrigated and drained soil-Continued } \\
\hline \multirow[t]{2}{*}{5} & J4-M & $7-8.5$ & 58.9 & & 1,100 & 25 & 2 & 3,300 & 429 & 8.0 & 6.9 \\
\hline & J4-M & $8.5-9$ & 54.3 & & 1,100 & 27 & 2 & 2,970 & 330 & 8.1 & 7.3 \\
\hline \multirow[t]{4}{*}{6} & J4-T & $0-3$ & 52.6 & $50-60$ & 1,100 & 33 & 2 & 3,800 & 990 & 7.7 & 6.5 \\
\hline & J4-T & $3-5.5$ & 58.3 & & 1,300 & 140 & 10 & 5,390 & 880 & 7.8 & 7.2 \\
\hline & J4-T & $5-6.5$ & 24.8 & & 300 & 34 & 2 & 2,320 & 132 & 7.6 & 6.8 \\
\hline & J4-T & $6.5-7.5$ & 24.5 & & 200 & 43 & 2 & - & - & - & - \\
\hline \multirow[t]{3}{*}{7} & J4-M & $0-3$ & 50. & $50-90$ & 1,300 & 30 & 6 & 1,320 & 204 & 7.3 & 7.1 \\
\hline & J4-M & $3-6$ & 54.6 & & 800 & 22 & 2 & 1,020 & 205 & 8.0 & 5.9 \\
\hline & J4-M & $6-9$ & 36.5 & & 600 & 61 & 6 & 1,180 & 145 & 7.6 & 6.9 \\
\hline \multirow[t]{3}{*}{8} & J4-M & $0-3$ & 56.8 & $70-90$ & 1,200 & 25 & 3 & 968 & 198 & 8.0 & 6.4 \\
\hline & J4-M & $3-6$ & 54.2 & & 900 & 21 & 2 & 913 & 178 & 8.0 & 6.6 \\
\hline & J4-M & $6-8$ & 56.6 & & 1,000 & 21 & 2 & 770 & 165 & 8.0 & 6.7 \\
\hline 10 & J4-B & $0-2$ & 59 & - & 1,800 & 26 & 5 & 3,360 & 572 & 8.1 & 7.2 \\
\hline \multirow[t]{3}{*}{9} & J4-B & $0-3$ & 47.5 & $70-90$ & 700 & 380 & 25 & 24,800 & 3,520 & 7.9 & 7.3 \\
\hline & J4-B & $4-5$ & 21.3 & & 500 & 120 & 6 & 6,380 & 385 & 7.7 & 6.8 \\
\hline & J4-B & $5-5.5$ & 20.2 & & 800 & 30 & 3 & 10,100 & 1,010 & 8.2 & 6.9 \\
\hline \multicolumn{12}{|c|}{ Irrigated soil, not drained, between $\mathrm{J} 1$ and $\mathrm{J} 2$ drain outlets } \\
\hline \multirow[t]{2}{*}{16} & none & $1-3$ & 32.9 & - & 800 & 80 & 6 & 11,300 & 1,680 & 7.7 & 7.1 \\
\hline & none & 3.4 .2 & 27.5 & - & 600 & 120 & 6 & 3,850 & 275 & 7.0 & 6.4 \\
\hline \multirow[t]{2}{*}{17} & none & $1-3$ & 44.3 & - & 1,100 & 15 & 3 & 913 & 154 & 7.8 & 6.3 \\
\hline & none & 3-5.5 & 47.4 & - & 900 & 10 & 1 & 1,380 & 206 & 6.3 & 7.3 \\
\hline \multicolumn{12}{|c|}{ Efflorescence and shale } \\
\hline $\mathrm{J} 4 \mathrm{ef}$ & fflorescence & 1 & 59.9 & - & 3,1002 & 2,300 & 180 & 27,000 & 4,400 & 8.2 & 7.5 \\
\hline Mar & ncos Shale & - & 57.9 & - & 1,100 & 31 & 6 & 10,900 & 1,030 & 7.5 & 6.2 \\
\hline $\mathrm{VSL}^{1} \mathrm{Mar}$ & ncos Shale & - & 61.9 & - & 4,000 & 750 & 75 & 11,000 & 2,970 & 7.7 & 6.3 \\
\hline
\end{tabular}

${ }^{1}$ See figure 5 for location of Vernal sewage lagoons. 
Saturation extractions are costly, time consuming, and somewhat subjective in the determination of the point at which the sample is water saturated. The 1:10 (1 part soil to 10 parts water) extractions are less expensive, require less time, and avoid the subjectivity of the analyst; however, 1:10 extractions generally yield such small selenium concentrations that it is difficult to predict if problems resulting from the leaching of selenium from the soils will occur. There is no correlation between selenium concentrations determined using saturation and 1:10 extraction methods; however, there is a correlation between the yield of 1:10 extractions, in $\mu \mathrm{g}$ of selenium per $\mathrm{kg}$ of soil, and the yield of saturation extractions in $\mu \mathrm{g} / \mathrm{L}$. Although the regression for 1:10 and saturation extraction yields had a very large coefficient of determination $(R=0.991)$, the standard error of the $Y$ estimate was large $(49 \mu \mathrm{g} / \mathrm{kg})$, and predicted saturation values in the lower range $(0-30 \mu \mathrm{g} / \mathrm{kg})$ were often negative numbers. Even when the coefficient of determination approaches unity, the value of the dependent variable (the $\mathrm{Y}$ estimate of the saturation extraction in this case) may not actually be a result of its relation to the independent variable. Also, when the actual data span several orders of magnitude, as in this case, the coefficient of determination may not be an adequate indication of goodness of fit over the entire range. When the data were divided into two sets, the 9 samples with saturation yields in the range of 100 to $3,436 \mu \mathrm{g} / \mathrm{kg}$ had a coefficient of determination of 0.996 , while the remaining 38 samples with saturation yields in the range of 0.7 to $54.5 \mu \mathrm{g} / \mathrm{kg}$ had a coefficient of determination of 0.343 (fig. 30). This relation indicates that the regression is not an effective quantitative tool to predict saturation extract concentrations in the smaller range where most of the samples occur.

The regression of $1: 10$ extraction yields, in $\mu \mathrm{g} / \mathrm{kg}$, against saturation concentration also breaks down in the lower range that contains most of the population. When the 47 samples were divided into high and low range groups, the following statistics were derived: (1) For 23 of 47 samples with 1:10 yields $<30 \mu \mathrm{g} / \mathrm{kg}$, the $R^{2}$ value was 0.247 , and standard error of the Y estimate was $9.9 ;(2)$ for 24 of 47

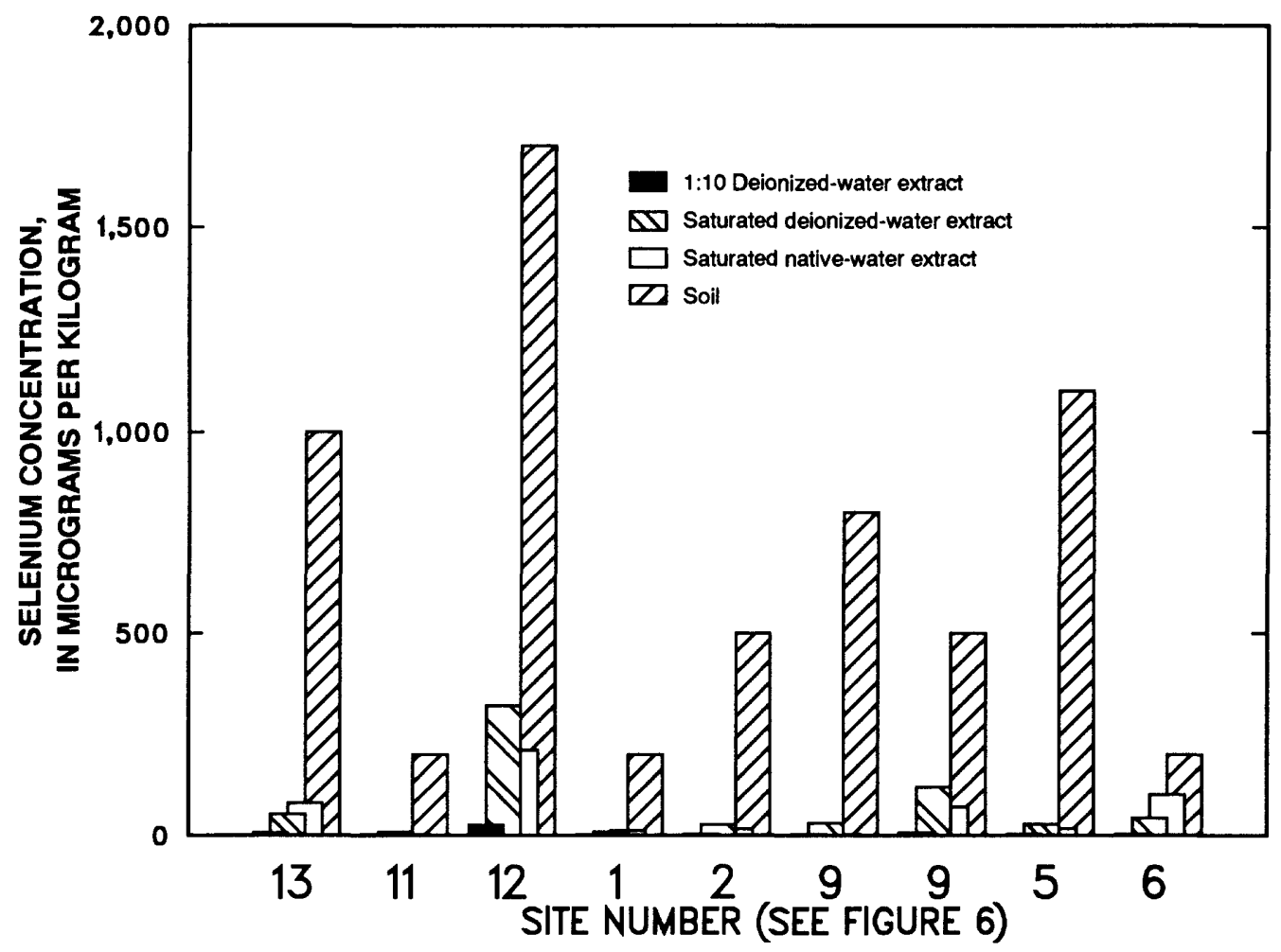

Figure 29. Quantity of selenium removed from nine samples of soil using three extraction procedures. 
Table 6. Selenium concentrations and values of specific conductance and $p H$ in native-water saturated soil and in soil that was dried and extracted using deionized water

$[\mu \mathrm{g} / \mathrm{kg}$, micrograms per kilogram; $\mu \mathrm{g} / \mathrm{L}$, micrograms per liter; $\mu \mathrm{S} / \mathrm{cm}$, microsiemens per centimeter; $\mathrm{M}$, middle of drain line; $\mathrm{T}$, top of drain line; $\mathrm{B}$, bottom of drain line near outlet; - , not determined]

\begin{tabular}{|c|c|c|c|c|c|c|c|c|c|}
\hline \multirow[b]{2}{*}{$\begin{array}{c}\text { Site } \\
\text { number } \\
\text { (fig. 6) }\end{array}$} & \multirow[b]{2}{*}{ Drain } & \multirow[b]{2}{*}{$\begin{array}{c}\text { Sample } \\
\text { depth } \\
\text { (feet) }\end{array}$} & \multicolumn{3}{|c|}{ Selenium concentration } & \multicolumn{2}{|c|}{ Specific conductance } & \multicolumn{2}{|c|}{$\mathrm{pH}$} \\
\hline & & & $\begin{array}{c}\text { Soil } \\
(\mu g / \mathrm{kg})\end{array}$ & $\begin{array}{c}\text { Native } \\
\text { water } \\
\text { satur- } \\
\text { ation } \\
\text { extract } \\
(\mu \mathrm{g} / \mathrm{L})\end{array}$ & $\begin{array}{c}\text { Deio- } \\
\text { nized } \\
\text { water } \\
1: 10 \\
\text { extract } \\
(\mu \mathrm{g} / \mathrm{L})\end{array}$ & $\begin{array}{l}\text { Native } \\
\text { water } \\
\text { satur- } \\
\text { ation } \\
\text { extract } \\
(\mu \mathrm{S} / \mathrm{cm})\end{array}$ & $\begin{array}{c}\text { Deio- } \\
\text { nized } \\
\text { water } \\
1: 10 \\
\text { extract } \\
(\mu \mathrm{S} / \mathrm{cm})\end{array}$ & $\begin{array}{c}\text { Native } \\
\text { water } \\
\text { satur- } \\
\text { ation } \\
\text { extract } \\
\text { (units) }\end{array}$ & $\begin{array}{c}\text { Deio- } \\
\text { nized } \\
\text { water } \\
1: 10 \\
\text { extract } \\
\text { (units) }\end{array}$ \\
\hline \multicolumn{10}{|c|}{ Native-water saturated soil samples } \\
\hline 13 & J1-M & $3-5$ & 1,000 & 80 & 6 & 7,260 & 2,200 & 7.9 & 7.2 \\
\hline 11 & J2-T & $6-9$ & 300 & 1 & 1 & 880 & 68 & 8.4 & 6.9 \\
\hline 12 & J2-T & $3-6$ & 1,800 & 210 & 25 & 12,300 & 2,810 & 7.7 & 6.4 \\
\hline 1 & J3-B & $6.5-6.8$ & 400 & 11 & 1 & 3,300 & 143 & 7.5 & 6.2 \\
\hline 2 & J3-M & $5.5-7$ & 400 & 15 & 2 & 1,230 & 220 & 8.0 & 6.6 \\
\hline 9 & J4-B & 5-5.5 & 400 & 2 & 2 & 11,200 & 1,190 & 8.1 & 7.2 \\
\hline 9 & J4-B & $4-5$ & 500 & 70 & 3 & 6,160 & 374 & 8.1 & 6.7 \\
\hline 5 & J4-M & $8.5-9$ & 1,300 & 16 & 2 & 2,310 & 253 & 7.3 & 6.5 \\
\hline 6 & J4-T & $6.5-7.5$ & 300 & 100 & 3 & 3,960 & 193 & 7.2 & 6.7 \\
\hline \multicolumn{10}{|c|}{$\begin{array}{l}\text { Native-water saturated soil samples, } \\
\text { dried and extracted with distilled water }\end{array}$} \\
\hline 13 & J1-M & $3-5$ & 1,000 & 53 & 6 & 6,820 & 1,990 & 7.9 & 7.1 \\
\hline 11 & J2-T & $6-9$ & 200 & 8 & 1 & 704 & 79 & 8.1 & 6.7 \\
\hline 12 & J2-T & $3-6$ & 1,700 & 320 & 25 & 12,500 & 2,810 & 7.6 & 7.7 \\
\hline 1 & J3-B & $6.5-6.8$ & 200 & 8 & 1 & 2,420 & 131 & 6.7 & 5.8 \\
\hline 2 & J3-M & $5.5-7$ & 500 & 26 & 3 & 2,040 & 242 & 7.8 & 7.5 \\
\hline 9 & J4-B & $5-5.5$ & 800 & 30 & 3 & 10,100 & 1,010 & 8.2 & 6.9 \\
\hline 9 & J4-B & 4-5 & 500 & 120 & 6 & 6,380 & 385 & 7.7 & 6.8 \\
\hline 5 & J4-M & $8.5-9$ & 1,100 & 27 & 2 & 2,970 & 330 & 8.1 & 7.3 \\
\hline 6 & J4-T & $6.5-7.5$ & 200 & 43 & 2 & -- & -- & -- & -- \\
\hline
\end{tabular}

samples with $1: 10$ yields $>30 \mu \mathrm{g} / \mathrm{kg}$, the $\mathrm{R}^{2}$ value was 0.9864 . Again, this relation did not provide a quantitative tool allowing use of the 1:10 extractions to predict selenium concentrations for all ranges of concentration in the saturation extractions. These data indicate that the 1:10 extraction yields could be used in a semi-quantitative manner as shown in table 7 to estimate the range of selenium concentration likely to occur in the saturation extracts.

Although selenium concentrations from the soil extractions did not correlate well with the adjacent drainwater concentrations, the average of the saturation-extractable selenium concentrations in the vicinity of a drain were generally in the same order of magnitude as the drainwater concentrations. Because the average of the saturation extractions generally was larger, this constitutes a conservative estimate of the potential for selenium to leach from soils into drainwater in the area. In alkaline or saline soils, either the $1: 10$ extraction yield in $\mu \mathrm{g} / \mathrm{kg}$, or the saturationextraction concentration in $\mu \mathrm{g} / \mathrm{L}$ could be used to derive an initial estimate of the potential for selenium to leach into an irrigation drain. The use of water buffered within the range of the measured soil $\mathrm{pH}$ likely would yield better recoveries for the 1:10 extractions. 


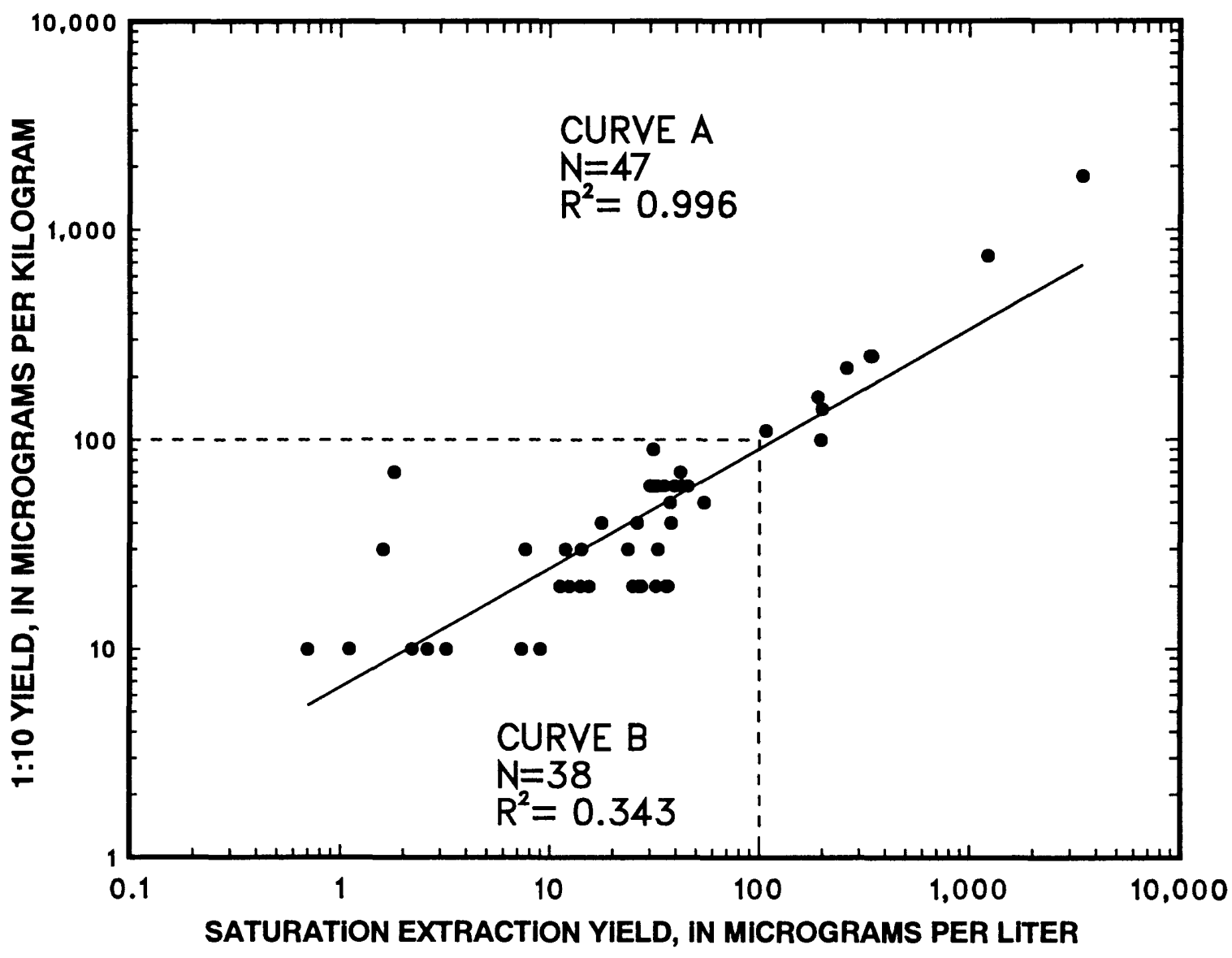

Figure 30. Relation of selenium yields obtained by 1:10 soil extractions to selenium yields obtained by saturation extractions.

The use of the 1:10 extraction yields to predict saturation-extraction concentrations may not be applicable to all soils. Several samples shown in table 6 gave very small saturation extraction concentrations compared with the 1:10 yield. The 1:10 extraction, therefore, only would be useful as a conservative estimate in determining the potential for irrigated soils to leach selenium. Generally, if the selenium concentration in the $1: 10$ extraction yield is less than $3 \mu \mathrm{g} / \mathrm{kg}$, the potential for a significant quantity of selenium to leach from the soils is probably small. When irrigated land shows a drainage problem, analysis of shallow ground water would be more useful than soil extractions to predict selenium contamination of the drainwater.

In alkaline or saline soils when 1:10 water-extractable selenium yields exceed $3 \mu \mathrm{g} / \mathrm{kg}$, or totalextractable soil selenium exceeds $1,000 \mu \mathrm{g} / \mathrm{kg}(1,000 \mathrm{ppb})$, or saturated water-extractable selenium exceeds $5 \mu \mathrm{g} / \mathrm{L}$; then additional studies would need to be done to quantify the selenium concentration in ground water. These studies would need to include a sufficient number of samples for saturation extraction to provide a statistically significant result and, most importantly, collection of ground-water samples from the soils if possible. If the water table is shallow, saturated samples need to be collected and the fluids extracted as in a saturation-extraction procedure. The area needs to be evaluated to determine the hydrogeology, potential for shallow ground-water accumulation resulting in soil drainage problems, or deeper migration of the ground water that could adversely effect an important fresh-water aquifer. 
Table 7. Predicted ranges of saturation-extract yield of selenium from 1:10 extraction yields

$[\mu \mathrm{g} / \mathrm{kg}$, micrograms per kilogram; $\mu \mathrm{g} / \mathrm{L}$, micrograms per liter; <, less than; >, greater than]

\begin{tabular}{cc}
\hline $\begin{array}{c}\text { 1:10 extraction yield } \\
\text { of selenium } \\
(\mu \mathrm{g} / \mathrm{kg})\end{array}$ & $\begin{array}{c}\text { Saturation-extract yield } \\
\text { of selenium } \\
(\mu \mathrm{g} / \mathrm{L})\end{array}$ \\
\hline$<3$ & $<5$ \\
$3-9$ & $5-10$ \\
$10-49$ & $10-50$ \\
$49-99$ & $50-100$ \\
$100-499$ & $100-500$ \\
$>500$ & $>500$ \\
\hline
\end{tabular}

Establishing universal criteria for acceptable total selenium concentration in soil for irrigable land is not practical. Data for total selenium in soils, saturation extractions, and a reasonable understanding of the ground-water-flow path would be useful to predict selenium problems in drainwater from irrigated land or land being considered for irrigation. Predicting rates of selenium leaching and subsequent movement in ground water does not appear to be practical in the Jensen area and may not be feasible in most alkaline geochemical settings.

The existing data did not support development of a model to predict leaching rates for selenium for the 750-acre drain system in Jensen. The soils are variable, being either clays of Mancos Shale origin, alluvium from the Green River and local tributary streams, or combinations of these. Seams of graded coarse sand, gravel, and clay make permeability highly variable both vertically and horizontally. This variability complicates hydraulic modeling, and when combined with the complexity of selenium chemistry, makes predictions of mobility very difficult.

Examination of the data on concentrations of extractable selenium in the Jensen soils leads to the conclusion that drainwater from those soils would exceed the aquatic-life standard of $5 \mu \mathrm{g} / \mathrm{L}$ and would probably range from 30 to $100 \mu \mathrm{g} / \mathrm{L}$. There is, however, a high probability that most ground water from Cretaceous formations in the region would contain selenium concentrations that would exceed $5 \mu \mathrm{g} / \mathrm{L}$.

\section{Association of selenium with soil type in the Jensen area}

Mancos Shale, with a thickness exceeding 5,000 ft, underlies most of the Jensen area and extends into Vernal and along part of Ashley Creek. Soils in these areas are derived from alluvial material and from Mancos Shale. As with many other Cretaceous shales, the Mancos Shale is seleniferous, and selenium-concentrating plants growing on it may accumulate as much as $2,000 \mathrm{ppm}$ of selenium (Rosenfeld and Beath, 1964, p. 54). Strahorn and others (1924) mapped 19 soil types during a detailed soil survey of the Ashley Creek and Jensen areas (fig. 31). These included the Billings series, derived directly from Mancos Shale, and the Naples series, locally underlain by soils of the Billings series. Large selenium concentrations in water samples collected during 1986-89 from springs, shallow wells, and subsurface drains in the Vernal and Jensen areas show a close association to soils of Billings clay and Naples loam.

Soils of the Billings series consist of old alluvial-fan and footslope material derived mainly from erosion of Mancos Shale that have been modified through oxidation and accumulation of small quantities of organic matter. The principal type of the Billings series in the area is the Billings clay, a light grayish-brown to light-gray compact clay, $6 \mathrm{ft}$ or more in depth with subsoils often olive drab when freshly exposed. In some areas, the surface soil is somewhat lighter textured and less compact, 


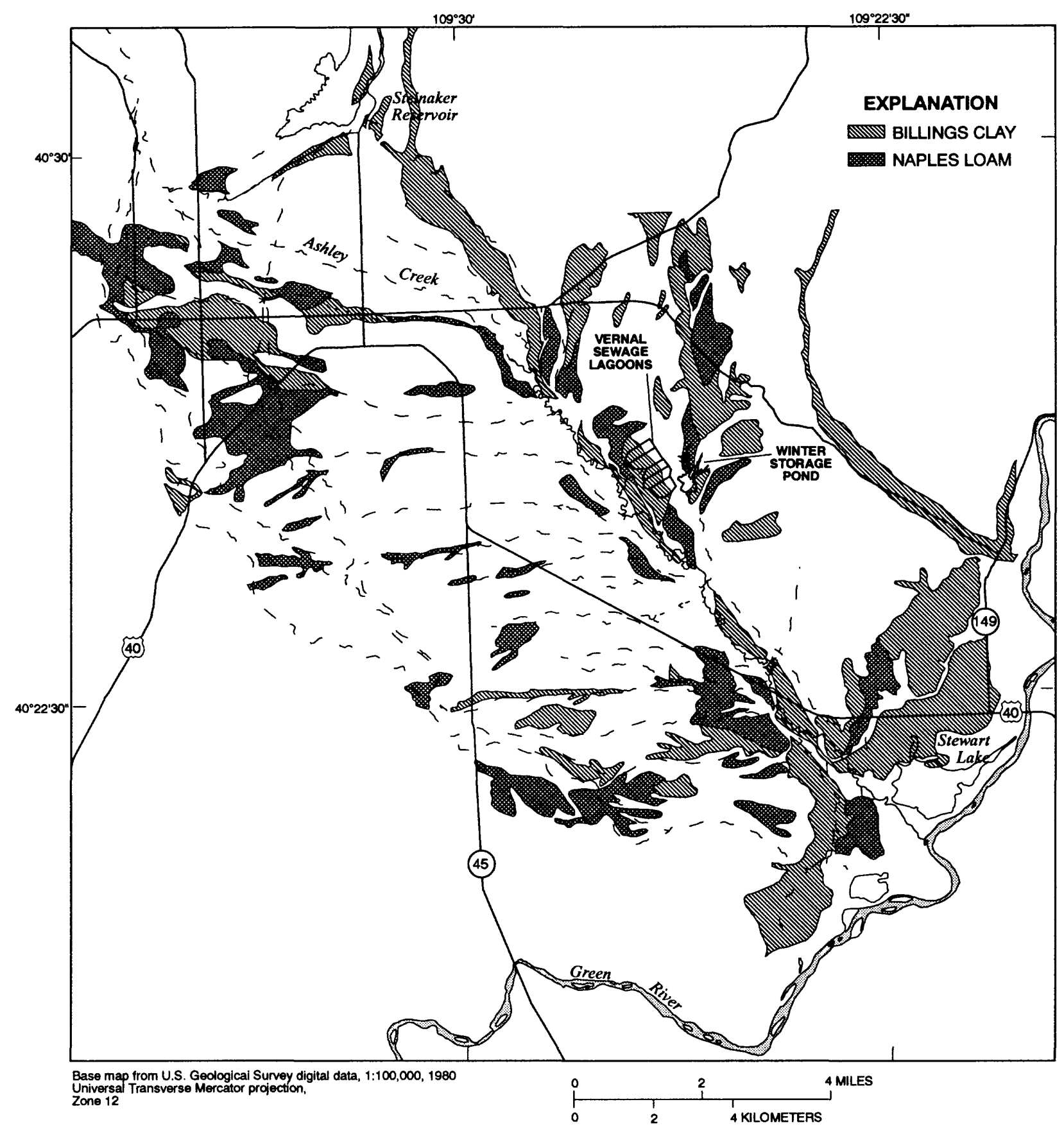

Figure 31. Locations of soil of the Billings clay and Naples loam series in the Stewart Lake area and along Ashley Creek and its tributaries.

and the subsoil contains strata with large quantities of very fine sand. Crystals of gypsum (hydrous calcium sulfate) are present. The largest area of Billings clay is north of Stewart Lake and comprises virtually all of the soil. Williams and Byers $(1935, \mathrm{p}$. 432) report selenium concentrations ranging from 2,000 to $8,000 \mathrm{ppb}$ for six samples of Billings clay loam taken from western Colorado, and an alkaline crust resulting from seepage through Billings clay loam contained a selenium concentration of 52,000 $\mathrm{ppb}$. 
Naples loam is a recent alluvial soil consisting of pale red to pronounced reddish-brown surface soils. It is a sticky loam, 10-12 in. deep, underlain by either a clay loam or a compact clay, and extends to a depth of $6 \mathrm{ft}$. Included within this series as mapped by Strahorn and others (1924) are local areas of soils in which the subsoil consists mainly of the Billings series, over which the Naples material has been superimposed. In these areas, the subsoil is heavy textured, compact, and of an olive-drab or grayish-brown color. In other local areas included within the Naples series, the surface soils are underlain at depths of 12 to $36 \mathrm{in}$. by beds of shale or by an olive-drab clay derived from the decomposition of shales.

Selenium concentrations in drainwater from the Jensen area ranged from 4 to $92 \mu \mathrm{g} / \mathrm{L}$. Drains $\mathrm{J} 1, \mathrm{~J} 2, \mathrm{~J} 3$, and $\mathrm{J} 4$ are in soils of Billings clay, and the mean selenium concentration in water from these drains was $53.6 \mu \mathrm{g} / \mathrm{L}$. Drain J1A is short and drains Naples fine sandy loam soil. This soil type has subsoil of clay loam and is generally underlain by gravel. The only exposure of shale underlying this soil type was at $15-25 \mathrm{ft}$ (Strahorn and others, 1924, p. 926). The mean selenium concentration in water from drain J1A was 8.1 $\mu \mathrm{g} / \mathrm{L}$. The mean selenium concentration in two shallow (less than $14 \mathrm{ft}$ ) wells in this soil was $10 \mu \mathrm{g} / \mathrm{L}$. For comparison, selenium concentrations in 21 shallow (less than $20 \mathrm{ft}$ ) wells drilled in Billings clay in the Jensen area have ranged from 1 to $360 \mu \mathrm{g} / \mathrm{L}$, with a mean of $40 \mu \mathrm{g} / \mathrm{L}$.

\section{Biological Observations and Contamination in Biota}

\section{Nesting Observations at Marsh 4720 and Wheeler Pond near Stewart Lake Waterfowl Management Area}

Nesting studies initiated in 1988 and completed in 1989 consisted of searches for occupied nests and observations of use. Searches near Stewart Lake WMA in 1988 included the area known as marsh 4720, about $1 \mathrm{mi}$ southwest of Stewart Lake. Although marsh 4720 is linked to Ashley Creek by a canal system, it is biologically similar to nearby Stewart Lake. Marsh 4720 went dry during the summer of 1988 and remained dry during 1989. Searches in 1989 included a small area referred to as Wheeler Pond, about $1 \mathrm{mi}$ southwest of marsh 4720 (fig. 32). Searches were made for nests of all species of ducks, Canada geese, yellow-headed blackbirds (Xanthocephalus xanthocephalus), American coot, black-crowned night heron, pied-billed grebe (Podilymbus podiceps), and western grebe (Aechmophorus occidentalis).

Only 19 nests were located in 1988 and 23 in 1989 (table 8), excluding blackbird nests. Of these, a total of 10 duck, 1 Canada goose, 6 black-necked stilt (Himantopus mexicanus), and 2 common snipe (Gallinago gallinago) nests were located in the vicinity of Stewart Lake and marsh 4720 in 1988. All 23 waterbird nests in 1989 were near Stewart Lake and included 6 Canada goose, 6 black-crowned night heron, 5 western grebe, 2 killdeer, and 4 duck nests. Observations from the nests of cinnamon teal (Anas cyanoptera) and blue-winged teal (A. discors) were combined and called cinnamon teal because nesting females are not separable to species in the field. Most, if not all, of these nests were probably cinnamon teal.

No American coot nests were located either year, although one live and one dead young coot were found in an oxbow area immediately adjacent to the dike of Stewart Lake in 1988. The lack of American coot nests is notable because adult birds were present on Stewart Lake when nests should have been initiated. Nesting habitat was available near the J4 drain in both years, and marginal habitat appeared to be available both years on the lake. These coots were not observed aggressively displaying or defending territories, suggesting that the birds were not healthy. It is unlikely that American coots not defending or attempting to establish or defend territories would have remained in an area where food was inadequate.

The outcome of nests monitored for success at Stewart Lake WMA is shown in table 8. Not all nests monitored were followed through to a time when eggs should have hatched or when incubation was discontinued prematurely. Only 18 (51 percent) of the 35 nests where the fate was known were classified as successful. Fates of three nests were undetermined because of modification of the nest sites between visits. Predation was attributed to the loss of 11 nests (31 percent). The remaining seven 


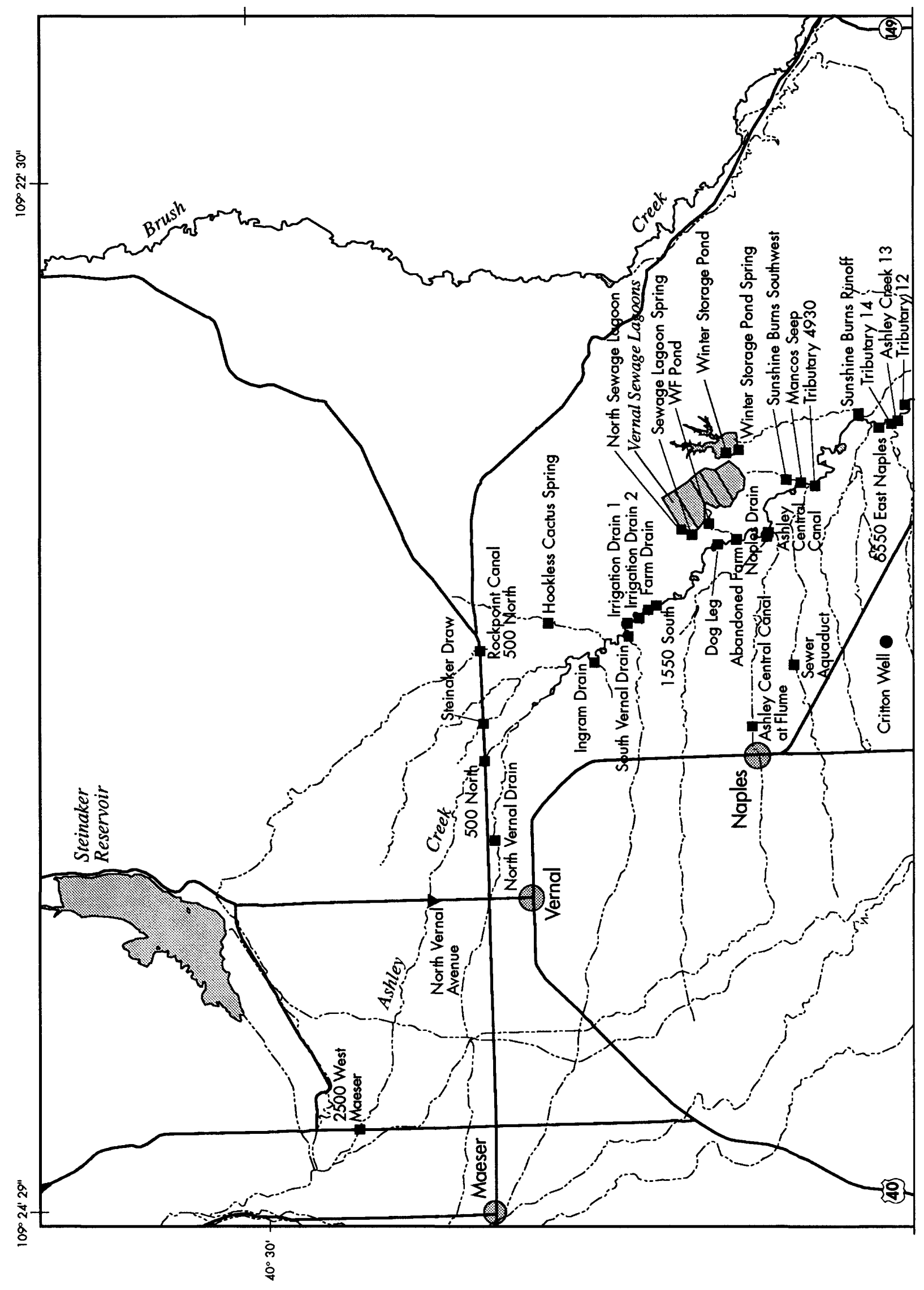




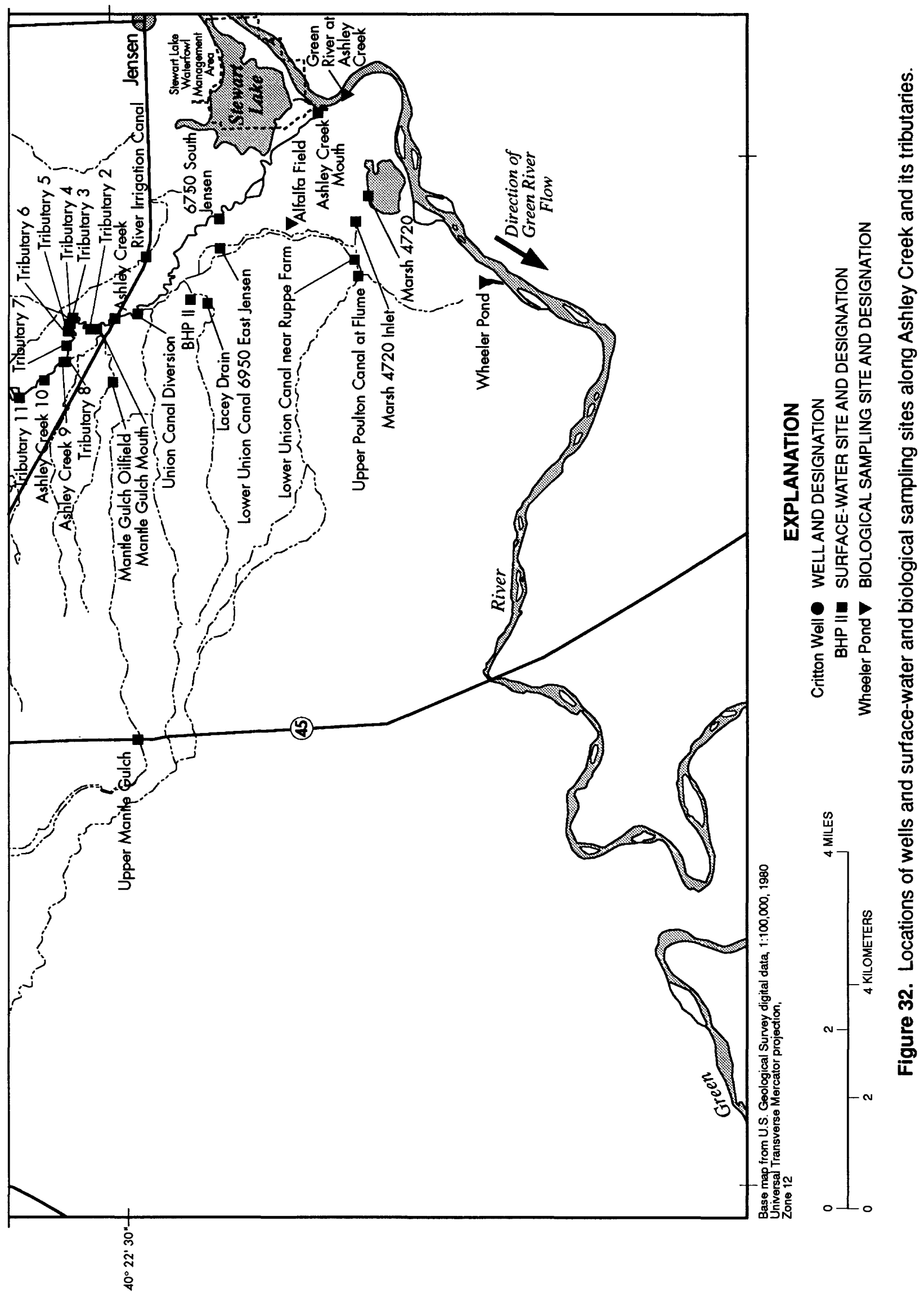


Table 8. Nesting success of waterbirds at Stewart Lake and marsh 4720, 1988-89

[Percent success: percentage of monitored nests known to hatch at least one egg; - , not applicable]

\begin{tabular}{llrr}
\hline \multicolumn{1}{c}{ Site } & \multicolumn{1}{c}{ Species } & $\begin{array}{c}\text { Monitored } \\
\text { nests }\end{array}$ & $\begin{array}{c}\text { Percent } \\
\text { success }\end{array}$ \\
\hline Stewart Lake & Black-crowned night heron & 6 & 83 \\
& Common snipe & 1 & 0 \\
& Canada goose & 7 & 57 \\
& Gadwall & 1 & 100 \\
& Killdeer & 2 & 50 \\
Mallard & 2 & 0 \\
& Redhead & 4 & 50 \\
& Cinnamon teal & 7 & 0 \\
& Western grebe & 5 & 80 \\
& Subtotal & 35 & - \\
Success for all nests combined & - & 51 \\
Marsh 4720 & \multicolumn{2}{c}{5} & 0 \\
& Black-necked stilt & 6 & 0 \\
& Common snipe & 1 & - \\
& Subtotal & 7 & 0 \\
\hline
\end{tabular}

nests were abandoned or destroyed by fire or other causes. Nesting success where fates were determined for western grebes was 80 percent (four of five nests).

Nests monitored at marsh 4720 were unsuccessful primarily as a result of predation. Youngof-year Canada geese were observed in 1987 and 1988, indicating that Canada geese may have nested successfully during those years.

Deformed embryos were observed at two nests. One redhead (Aythya americana) nest had at least two deformed embryos and an additional three eggs with dead embryos with no apparent external deformities. Both deformed redhead embryos had reduced lower bills and eye abnormalities. Apparent deformities were observed in one egg from a teal (most likely cinnamon teal) nest, but confirmation of deformities was limited by decomposition of the embryo. Two eggs from this nest were placed in an incubator, but only one hatched (Charles Henny, U.S. Fish and Wildlife Service, written commun., 1989). A Canada goose nest was known to have a dead embryo but was located close to the outlet, an area receiving substantial public use. Dead embryos were observed at other nests, but cause of death was attributed to abandonment.

\section{Observations of Waterbird Use}

Waterbird use of Stewart Lake WMA was documented about every 1-2 weeks in 1988-89. Observations for marsh 4720 are mostly restricted to 1988 because the marsh dried up in September of that year and remained dry in 1989. Maximum duck use at both sites exceeded 120 birds per observation in April, with median counts near 50 birds. Seasonal use was greatest during spring and late summer and represented migration. Use at Stewart Lake during June through August was usually less than 20 ducks. Counts at Stewart Lake were usually made from two sites: the knoll on the north side of the lake at the public access point and the outlet structure on the south side of the lake. Counts at marsh 4720 were made along the north shore where topographic relief provided the best visibility. Birds using areas of emergent vegetation on the east side of Stewart Lake and near the 
$\mathrm{J} 3$ and $\mathrm{J} 4$ drains would not have been visible. At marsh 4720, birds using the east half of the east pond were not visible; however, this area received no use in 1989 because of dry conditions. On the basis of field observations, few birds used the wetlands near the J3 and J4 drains. The east end of marsh 4720 contained numerous ducks at times. Many of these were males, and others were likely unsuccessful nesters.

American coots were present at Stewart Lake at times when coot nesting was ongoing at other sites near Stewart Lake; however, no nests were found on Stewart Lake. Counts of American coots never exceeded 32 birds, and median observed counts in spring were never larger than 10 birds. Few American coots were observed after July. The presence of downy chicks adjacent to the dike retaining Stewart Lake indicated that one unlocated nest existed there. Habitat, in terms of the abundance and distribution of emergent vegetation and adequate water depth, was available near the outlet and near the J4 drain.

An active nesting rookery of great blue herons (Ardea herodias) located on an island in the Green River opposite Stewart Lake WMA hatched at least 18 chicks in 1988 and 10 chicks in 1989 . In 1989, an estimated 29 nests were occupied, and in 1988, 24 nests were occupied, as indicated by the presence of adults on nests. Use of Stewart Lake by great blue herons was largest in April when the water level of the Green River was high.

Totals of all duck species counted during biweekly surveys were large in April and September, during migration at Stewart Lake. Individual counts ranged from 2 gadwalls on May 31 to 192 ducks in September. No biweekly counts were made during October; however, waterfowl were collected during October 1988 when an estimated 100-200 ducks and 250-400 Canada geese were using the area. These data indicate maximal waterfowl use during spring and fall migration and contrast sharply with minimal use of the area for breeding and for brood rearing.

Total counts of ducks at marsh 4720 were also large during April and July. These data do not include bird use of the east end of marsh 4720 where casual observations in early summer indicated much use. After May 31, 1989, the marsh dried up and received no use by ducks.

Species of waterbirds recorded during biweekly counts are shown in table 9 . The list is not a complete survey of waterbirds using each site but represents those species most commonly observed using the area. The endangered whooping crane and bald eagle are known to use the area near these two sites during migration but were not observed during counts in this study.

Counts of waterbird broods were conducted in 1988 and 1989 at separate times from the biweekly use counts. Canada goose was the primary species using Stewart Lake WMA for brood rearing, but use was sporadic and the fate of these broods was unknown. It is suspected that broods of Canada geese moved onto and away from Stewart Lake depending upon the availability of islands in the adjacent Green River as a result of fluctuating water levels of the river. Highest counts of goslings were 20 in 1988 and 11 in 1989 . No American coot broods were observed on Stewart Lake in 1988 or 1989 , but one live and one dead hatchling were observed in a wetland on the opposite side of the Stewart Lake dike near the outlet structure. Only five waterbird (duck or grebe) broods were observed during the two years, with average brood size less than two birds.

Canada goose was the primary species observed using marsh 4720 for brood rearing; however, the fate of the Canada goose broods is unknown. The maximum number of juvenile geese observed was 37 goslings in 7 broods. One mallard brood consisting of 5 young was observed. No American coot broods were observed on marsh 4720 in 1988. The pond was dry in 1989. 
Table 9. List of species observed during waterbird counts at Stewart Lake and marsh 4720, and at Roadside Ponds and Sheppard Bottom at Ouray National Wildlife Refuge, 1988-89

\begin{tabular}{|c|c|c|c|c|c|c|}
\hline \multirow{3}{*}{$\begin{array}{c}\text { SPECIES } \\
\text { Common name }\end{array}$} & \multicolumn{6}{|c|}{ OBSERVATION SITES } \\
\hline & \multirow{2}{*}{$\begin{array}{l}\text { Stewart } \\
\text { Lake }\end{array}$} & \multirow{2}{*}{$\begin{array}{c}\text { Marsh } \\
4720\end{array}$} & \multirow{2}{*}{$\begin{array}{l}\text { North } \\
\text { Roadside } \\
\text { Pond }\end{array}$} & \multirow{2}{*}{$\begin{array}{c}\text { South } \\
\text { Roadside } \\
\text { Pond }\end{array}$} & \multicolumn{2}{|c|}{ Sheppard Bottom } \\
\hline & & & & & Pond S3 & Pond S5 \\
\hline Great blue heron & $\mathrm{x}$ & $\mathrm{x}$ & & $\mathrm{x}$ & $\mathrm{x}$ & $\mathrm{x}$ \\
\hline Black-crowned night heron & $\mathrm{X}$ & $\mathrm{X}$ & & & $\mathrm{X}$ & $\mathrm{X}$ \\
\hline White-faced ibis & $\mathrm{X}$ & $\mathrm{X}$ & & $\mathrm{x}$ & $\mathrm{X}$ & \\
\hline Snowy egret & & & $\mathrm{X}$ & & $\mathrm{X}$ & $\mathrm{X}$ \\
\hline Great egret & $\mathrm{X}$ & & & $\mathrm{X}$ & & \\
\hline Sandhill crane & $\mathrm{X}$ & $\mathbf{x}$ & & & $\mathrm{X}$ & \\
\hline Double-crested cormorant & $\mathrm{X}$ & $\mathrm{X}$ & & $\mathrm{X}$ & $\mathrm{x}$ & $\mathrm{x}$ \\
\hline American white pelican & & & & & $\mathrm{X}$ & $\mathbf{x}$ \\
\hline Franklin's gull & $\mathrm{X}$ & & & & & \\
\hline Tundra swan & & & & & $\mathbf{x}$ & \\
\hline Canada goose & $\mathrm{x}$ & $\mathrm{x}$ & & & $\mathrm{x}$ & $\mathrm{x}$ \\
\hline Snow goose & $\mathrm{X}$ & & & & $\mathrm{X}$ & \\
\hline White-fronted goose & & & & & $\mathrm{x}$ & \\
\hline Mallard & $\mathrm{x}$ & $\mathrm{X}$ & $\mathrm{X}$ & $\mathrm{X}$ & $\mathrm{x}$ & $\mathrm{X}$ \\
\hline Northern pintail & $\mathrm{X}$ & $\mathbf{X}$ & $\mathbf{X}$ & & $\mathrm{X}$ & $\mathrm{X}$ \\
\hline Gadwall & $\mathrm{X}$ & $\mathbf{X}$ & $\mathrm{X}$ & $\mathrm{x}$ & $\mathrm{X}$ & $\mathrm{X}$ \\
\hline American wigeon & & $\mathrm{X}$ & $\mathbf{X}$ & $\mathrm{X}$ & $\mathbf{X}$ & $\mathrm{X}$ \\
\hline Northern shoveler & $\mathrm{X}$ & $\mathrm{X}$ & $\mathrm{X}$ & $\mathrm{X}$ & $\mathrm{X}$ & $\mathrm{X}$ \\
\hline Blue-winged teal & $\mathrm{X}$ & $\mathrm{X}$ & $\mathbf{X}$ & $\mathrm{X}$ & & \\
\hline Cinnamon teal & $\mathbf{X}$ & $\mathrm{X}$ & $\mathbf{X}$ & $\mathrm{X}$ & $\mathrm{X}$ & $\mathrm{x}$ \\
\hline Green-winged teal & $\mathrm{x}$ & $\mathrm{X}$ & $\mathrm{x}$ & $\mathrm{X}$ & $\mathrm{X}$ & $\mathrm{x}$ \\
\hline Wood duck & & & & & & $\mathrm{X}$ \\
\hline Redhead & $\mathrm{X}$ & $\mathrm{X}$ & $\mathrm{X}$ & $\mathrm{X}$ & $\mathrm{X}$ & $\mathrm{x}$ \\
\hline Scaup & $\mathrm{X}$ & & $\mathbf{x}$ & $\mathbf{X}$ & $\mathrm{X}$ & $\mathrm{x}$ \\
\hline Bufflehead & $\mathrm{x}$ & & & $\mathrm{X}$ & $\mathrm{X}$ & \\
\hline Common merganser & $\mathrm{X}$ & & & & & \\
\hline Ruddy duck & $\mathrm{X}$ & $\mathrm{X}$ & $\mathrm{x}$ & & $\mathrm{x}$ & \\
\hline Goldeneye & $\mathrm{X}$ & $\mathbf{X}$ & & & & $\mathrm{x}$ \\
\hline American coot & $\mathrm{X}$ & $\mathrm{x}$ & $\mathrm{X}$ & $\mathrm{X}$ & $\mathrm{x}$ & $\mathrm{X}$ \\
\hline Pied-billed grebe & & & $\mathbf{X}$ & $\mathbf{X}$ & $\mathrm{X}$ & $\mathrm{x}$ \\
\hline Eared grebe & $\mathbf{x}$ & & & & & $\mathrm{X}$ \\
\hline Western grebe & $\mathrm{X}$ & $\mathrm{x}$ & $\mathrm{X}$ & & $\mathrm{X}$ & \\
\hline Black-necked stilt & $\mathrm{X}$ & $\mathbf{X}$ & & $\mathbf{X}$ & $\mathrm{X}$ & $\mathrm{X}$ \\
\hline American avocet & $\mathrm{X}$ & $\mathbf{x}$ & & $\mathrm{X}$ & $\mathrm{X}$ & $\mathrm{X}$ \\
\hline Willet & & & & & $\mathrm{X}$ & \\
\hline Killdeer & & $\mathrm{X}$ & $\mathbf{x}$ & & $\mathrm{X}$ & \\
\hline Long-billed dowitcher & $\mathrm{X}$ & $\mathrm{X}$ & & & $\mathrm{X}$ & $\mathrm{x}$ \\
\hline Wilson's phalarope & $\mathrm{X}$ & $\mathrm{X}$ & & & $\mathrm{X}$ & $\mathrm{X}$ \\
\hline Semipalmated sandpiper & & $\mathrm{x}$ & & & & \\
\hline Black-bellied plover & & $\mathbf{x}$ & & & & \\
\hline Forster's tern & $\mathrm{X}$ & $\mathrm{X}$ & $\mathrm{X}$ & $\mathrm{X}$ & $\mathrm{X}$ & $\mathrm{x}$ \\
\hline Black tern & & & & & $\mathrm{x}$ & \\
\hline Cliff swallow & & & $\mathbf{x}$ & $\mathrm{X}$ & $\mathrm{X}$ & \\
\hline Bank swallow & & $\mathrm{X}$ & $\mathrm{X}$ & $\mathrm{X}$ & $\mathrm{x}$ & \\
\hline Barn swallow & & $\mathrm{X}$ & $\mathrm{X}$ & $\mathrm{X}$ & $\mathrm{X}$ & \\
\hline Tree swallow & & $\mathrm{X}$ & $\mathrm{x}$ & $\mathrm{X}$ & & \\
\hline
\end{tabular}


Table 9.-List of species observed during waterbird counts at Stewart Lake and marsh 4720, and at Roadside Ponds and Sheppard Bottom at Ouray National Wildlife Refuge, 1988-89-Continued

\begin{tabular}{|c|c|c|c|c|c|c|}
\hline \multirow{3}{*}{$\begin{array}{c}\text { SPECIES } \\
\text { Common name }\end{array}$} & \multicolumn{6}{|c|}{ OBSERVATION SITES } \\
\hline & \multirow{2}{*}{$\begin{array}{l}\text { Stewart } \\
\text { Lake }\end{array}$} & \multirow{2}{*}{$\begin{array}{c}\text { Marsh } \\
4720\end{array}$} & \multirow{2}{*}{$\begin{array}{c}\text { North } \\
\text { Roadside } \\
\text { Pond }\end{array}$} & \multirow{2}{*}{$\begin{array}{c}\text { South } \\
\text { Roadside } \\
\text { Pond }\end{array}$} & \multicolumn{2}{|c|}{ Sheppard Bottom } \\
\hline & & & & & Pond S3 & Pond S5 \\
\hline Yellow-headed blackbird & $\mathrm{X}$ & & $\mathrm{X}$ & $\mathrm{X}$ & $\mathbf{X}$ & $\mathbf{X}$ \\
\hline Red-winged blackbird & $\mathrm{X}$ & & $\mathrm{X}$ & $\mathrm{X}$ & $\mathrm{X}$ & $\mathrm{X}$ \\
\hline Mourning dove & $\mathrm{X}$ & $\mathrm{X}$ & & & & \\
\hline Northern harrier & $\mathrm{X}$ & & & & $\mathrm{X}$ & $\mathrm{X}$ \\
\hline Osprey & $\mathrm{X}$ & & & & & \\
\hline Bald eagle & & & & & $\mathrm{X}$ & $\mathrm{X}$ \\
\hline Golden eagle & & & & & $\mathrm{X}$ & $\mathrm{X}$ \\
\hline American kestrel & $\mathrm{X}$ & & & & & \\
\hline Red-tailed hawk & & & $\mathrm{X}$ & & $\mathrm{X}$ & \\
\hline
\end{tabular}

\section{Residue in Waterbirds}

A total of 42 randomly collected individual eggs or randomly collected composite samples of eggs and 7 individual non-randomly collected eggs were analyzed from the area within the boundary of Stewart Lake WMA and areas immediately adjacent to Stewart Lake. Mean selenium concentrations as dry weight by bird species in the randomly collected eggs ranged from a geometric mean of $3.3 \mu \mathrm{g} / \mathrm{g}$ for Canada goose eggs to $24.6 \mu \mathrm{g} / \mathrm{g}$ for western grebe eggs (table 10), which likely represents different diets and feeding sites. Canada geese fed at upland sites adjacent to Stewart Lake. The variable concentrations also might represent contamination obtained elsewhere during spring migration; however, this was not examined at Stewart Lake. As shown in figures 2 and 3, migrant birds moving north and south along the Green River are exposed to potential sources of contaminants from Mexico to Canada.

Selenium concentrations in the 49 egg samples collected in the Stewart Lake area ranged from $2 \mu \mathrm{g} / \mathrm{g}$ for a Canada goose egg to $33 \mu \mathrm{g} / \mathrm{g}$ for a western grebe egg (Peltz and Waddell, 1991, p. 97). Deformities were clearly observed in a redhead embryo that had a concentration of only $3.9 \mu \mathrm{g} / \mathrm{g}$ selenium and strongly suspected in a cinnamon teal embryo having a concentration of $2.7 \mu \mathrm{g} / \mathrm{g}$ selenium. This level is substantially smaller than the 15 to $20 \mu \mathrm{g} / \mathrm{g}$ selenium documented by Heinz and others (1987) to cause teratogenesis or embryo mortality. The measured concentrations of selenium in these two eggs seem unusually small because other eggs analyzed from these nests had much larger concentrations.

Skorupa and Ohlendorf (1991, table 4) estimated that mean selenium concentrations in eggs of $8 \mu \mathrm{g} / \mathrm{g}$ dry weight in a population and $10 \mu \mathrm{g} / \mathrm{g}$ in individual eggs are the approximate minimum levels of selenium concentrations in eggs associated with impaired hatchability in some species. They also suggested that in eggs of some species, mean concentrations of 13 to $24 \mu \mathrm{g} / \mathrm{g}$ of selenium were associated with teratogenic effects. Heinz and others (1989, p. 426 and 427) suggested reproductive impairment occurred between egg concentrations of 3.4 and $11 \mu \mathrm{g} / \mathrm{g}$ (wet weight) selenium in mallards (estimated at 11.3 and $36.7 \mu \mathrm{g} / \mathrm{g}$ dry weight); and that at concentrations that exceed $1 \mu \mathrm{g} / \mathrm{g}$ (about $3.3 \mu \mathrm{g} / \mathrm{g}$ dry weight), reproductive success should be closely monitored. Skorupa and Ohlendorf (1991, p. 349) concluded that the interquartile boundaries for 74 sample means for normal selenium concentrations in eggs was 1.4 to $2.4 \mathrm{ppm}$ ( 1.4 to $2.4 \mu \mathrm{g} / \mathrm{g}$ ) dry weight. 
Table 10. Geometric mean selenium concentrations in bird eggs and bird tissue from Stewart Lake

[All eggs were randomly collected except those that are indicated by NR, non-random sample; LV, liver; MS, muscle; WB, whole body; mm, millimeter; g, gram; $\mu \mathrm{g} / \mathrm{g}$, micrograms per gram (dry weight); - , not specified. Weight of bird egg is mean weight of contents. Mean length, weight, and moisture content are arithmetic means]

\begin{tabular}{|c|c|c|c|c|c|c|}
\hline Sample composition & $\begin{array}{l}\text { Sample } \\
\text { size }\end{array}$ & $\begin{array}{c}\text { Sample } \\
\text { type }\end{array}$ & $\begin{array}{c}\text { Mean } \\
\text { length } \\
(\mathrm{mm})\end{array}$ & $\begin{array}{c}\text { Mean } \\
\text { weight } \\
\text { (g) }\end{array}$ & $\begin{array}{l}\text { Mean } \\
\text { moisture } \\
\text { content } \\
\text { (percent) }\end{array}$ & $\begin{array}{c}\text { Geometric } \\
\text { mean selenium } \\
\text { concentration } \\
(\mu \mathrm{g} / \mathrm{g})\end{array}$ \\
\hline \multicolumn{7}{|c|}{ Bird eggs } \\
\hline Black-crowned night heron & 6 & Individual & 52 & 31 & 80.6 & 18.3 \\
\hline Canada goose (NR) & 3 & Individual & 85 & 100 & 67.0 & 4.5 \\
\hline Canada goose & 7 & Individual & 85 & 147 & 68.5 & 3.3 \\
\hline Cinnamon teal & 7 & Individual & 46 & 25 & 69.8 & 9.5 \\
\hline Gadwall & 2 & Individual & 52 & 30 & 66.8 & 20.9 \\
\hline Killdeer & 2 & Individual & 36 & 12 & 70.2 & 5.7 \\
\hline Mallard & 3 & Individual & 56 & 45 & 68.8 & 5.8 \\
\hline Redhead (NR) & 2 & Individual & 57 & 47 & 67.0 & 8.7 \\
\hline Redhead & 5 & Individual & 60 & 50 & 70.5 & 6.5 \\
\hline Western grebe & 7 & Individual & 59 & 39 & 77.6 & 24.6 \\
\hline Common snipe (NR) & 1 & Individual & 39 & 9 & 69.2 & 21.9 \\
\hline Common snipe & 1 & Individual & 38 & 14 & 76.1 & 21.3 \\
\hline Yellow-headed blackbird & 3 & Composite & 25 & 4 & 82.5 & 6.2 \\
\hline \multicolumn{7}{|c|}{ Bird tissue } \\
\hline American coot-Summer-(LV) & 6 & Individual & - & - & 73.7 & 10.2 \\
\hline American coot-Summer-(MS) & 6 & Individual & - & - & 70.8 & 4.7 \\
\hline American coot-Spring-(LV) & 1 & Individual & - & - & 77.7 & 8.39 \\
\hline American coot-Spring-(MS) & 1 & Individual & - & - & 71.9 & 2.78 \\
\hline American coot (WB) & 1 & Individual & - & - & 84.0 & 86.9 \\
\hline Canada goose (LV) & 1 & Individual & - & - & 70.8 & 3.66 \\
\hline Canada goose (MS) & 1 & Individual & - & - & 72.3 & 1.92 \\
\hline Green-winged teal (LV) & 1 & Individual & - & - & 74.2 & 20.6 \\
\hline Green-winged teal (MS) & 1 & Individual & - & - & 71.6 & 5.74 \\
\hline Mallard (LV) & 3 & Individual & - & - & 75.5 & 22.8 \\
\hline Mallard (MS) & 3 & Individual & - & - & 74.1 & 9.3 \\
\hline Northern shoveler (LV) & 4 & Individual & - & - & 66.9 & 12.4 \\
\hline
\end{tabular}

All eggs collected at Stewart Lake exceeded the normal range except a single Canada goose egg; 21 of 49 eggs analyzed exceeded the $11.3 \mu \mathrm{g} / \mathrm{g}$ estimated minimum level range for reproductive impairment (Heinz and others, 1989). Also, 26 of 49 eggs exceeded the $8 \mu \mathrm{g} / \mathrm{g}$ level indicated by Skorupa and Ohlendorf (1991) to be the approximate minimum level for reproductive impairment in populations of some species. Selenium concentrations in non-randomly collected eggs were similar to those in randomly collected eggs. The geometric mean for all redhead eggs categorized as non-random (two), regardless of number of duplicates (more than one per nest), was $8.7 \mu \mathrm{g} / \mathrm{g}$ compared to $6.5 \mu \mathrm{g} / \mathrm{g}$ for the five random eggs. For Canada geese, seven random eggs had a selenium concentration of 3.3 $\mu \mathrm{g} / \mathrm{g}$ compared to $4.5 \mu \mathrm{g} / \mathrm{g}$ for three non-random eggs (table 10 ). 
Tissue samples were collected and analyzed from many birds at Stewart Lake as indicated in table 10. One dead juvenile American coot from a wetland adjacent to the dike near the outlet of Stewart Lake had a whole-body selenium concentration of $86.9 \mu \mathrm{g} / \mathrm{g}$ (dry weight). An adult American coot found shot on April $14 \mathrm{had} 8.39 \mu \mathrm{g} / \mathrm{g}$ of selenium in its liver. Two adults and four juvenile American coots were collected in August and early September 1986 to represent summer resident waterbirds. The geometric mean selenium concentration in the livers of these birds was $10.2 \mu \mathrm{g} / \mathrm{g}$, and in breast muscle it was $4.7 \mu \mathrm{g} / \mathrm{g}$. Although the American coot collected in April was likely a recent migrant to Stewart Lake (ice melt usually occurs in early March), the selenium concentration in its liver was similar to concentrations of selenium in coots collected during the summer that were believed to be summer residents of Stewart Lake WMA.

The remainder of the tissue samples were collected during the fall to simulate hunter take and may represent both resident and migrant birds. These birds generally contained small selenium concentrations in the liver tissue and breast muscle. An exception was a mallard collected in the vicinity of the $\mathrm{J} 3$ drain that had selenium concentrations of $74.7 \mu \mathrm{g} / \mathrm{g}$ in its liver and 27.6 in the breast muscle (Peltz and Waddell, 1991, p.101).

Three black-necked stilt eggs collected from marsh 4720 for residue analysis had a geometric mean selenium concentration of $8.8 \mu \mathrm{g} / \mathrm{g}$ (table 11). These concentrations exceeded the $8 \mu \mathrm{g} / \mathrm{g}$ threshold associated with reproductive impairment (Skorupa and Ohlendorf, 1991, table 4). One common snipe (Gallinago gallinago) egg had a selenium concentration of $5.8 \mu \mathrm{g} / \mathrm{g}$.

\section{Residue in Fish}

Fish were collected primarily at the south shore of Stewart Lake within about $1,000 \mathrm{ft}$ of the outlet structure and along the north shore of the main body of Stewart Lake between the confluence of water from the $\mathrm{J} 1$ and $\mathrm{J} 1 \mathrm{~A}$ drains and water from the J2, J3, and $\mathrm{J} 4$ drains. One sample was also collected in the common channel for the $\mathrm{J} 2, \mathrm{~J} 3$, and $\mathrm{J} 4$ drains.

Geometric-mean concentrations of selenium in fish tissues from Stewart Lake (on the basis of location of collection) are shown in table 12. As a reference, the values are compared to a baseline selenium concentration of $2.9 \mu \mathrm{g} / \mathrm{g}$ from the National Contaminant Biomonitoring Program of the U.S. Fish and Wildlife Service (Schmitt and Brumbaugh, 1990). This program measures concentrations of trace elements in fish nationwide and represents an extensive data base useful for comparison. The value that includes 85 percent of all concentrations is reported and represents a nationwide norm for many trace elements found in fish. This value is useful in comparisons to values obtained in fish from other sites. If residues of elements in fish from sites suspected of contamination exceed this baseline, it is reasonable to state that the concentrations are large relative to the nationwide baseline; however, values larger than the baseline do not necessarily mean there is an adverse effect on the fish population. The mean selenium concentration in all fish tissue samples from Stewart Lake, except one whole-body catfish, exceeded a reference value of $12 \mu \mathrm{g} / \mathrm{g}$ (whole body) associated with reproductive failure in some fish species (Lemly and Smith, 1987, table 2) and were 5 to 12 times as large as the nationwide norm of $2.9 \mu \mathrm{g} / \mathrm{g}$.

The selenium concentration in whole-body fish tissue ranged from 4 to $83.9 \mu \mathrm{g} / \mathrm{g}$ (dry weight) (Peltz and Waddell, 1991, p. 93, 107). Zinc, an element that occasionally occurred in water at concentrations exceeding the State wildlife protection standard of $50 \mu \mathrm{g} / \mathrm{L}$ at the outflow from Stewart Lake (Stephens and others, 1988a), was present in whole-body fish tissues at concentrations ranging from $36.6 \mu \mathrm{g} / \mathrm{g}$ to $470 \mu \mathrm{g} / \mathrm{g}$.

In this study, when whole-fish data for all species collected from 1986 to 1989 were combined (table 12), fish collected closest to the drain outfalls contained a significantly larger selenium concentration (Mann-Whitney test, attained level of significance [ALS] 0.03). The species composition of samples taken at each site was about the same. The north shore samples were 30 and 61 percent black bullhead (Ictalurus melas) and common carp (Cyprinus carpio) respectively, compared to 36 and 52 percent for the same species for samples from the south shore. Carp were found to have substan- 
Table 11. Geometric mean selenium concentrations in biological samples collected from marsh 4720 and in fish samples collected nationwide by the National Contaminant Biomonitoring Program

[WB, whole body; MS, muscle; mm, millimeter; g, gram; $\mu \mathrm{g} / \mathrm{g}$, micrograms per gram (dry weight); -, not specified. NCBP, National Contaminant Biomonitoring Program, from Schmitt and Brumbaugh, 1990 (1984 geometric mean concentration, 85th percentile, converted to dry weight using 75 percent moisture). Weight of bird egg is mean weight of contents. Mean length, weight, and moisture content are arithmetic means]

\begin{tabular}{ccccccc}
\hline Organism & Sample & Sample & Mean \\
size & type & $\begin{array}{c}\text { Length } \\
(\mathrm{mm})\end{array}$ & $\begin{array}{c}\text { Mean } \\
\text { weight } \\
(\mathrm{g})\end{array}$ & $\begin{array}{c}\text { Mean } \\
\text { moisture } \\
\text { content } \\
(\text { percent })\end{array}$ & $\begin{array}{c}\text { Geometric } \\
\text { mean selenium } \\
\text { concentration } \\
(\mu \mathrm{g} / \mathrm{g})\end{array}$ \\
\hline
\end{tabular}

Fish

$\begin{array}{lrlrrrl}\text { Black bullhead (WB) } & 3 & \text { Composite } & 187 & 87 & 81.2 & 12.6 \\ \text { Common carp (WB) } & 6 & \text { Composite } & 359 & 569 & 77.7 & 26.2 \\ \text { Northern pike (WB) } & 1 & \text { Composite } & 510 & 681 & 79.1 & 12 \\ \text { Northern pike (MS) } & 1 & \text { Individual } & 482 & 647 & 79.3 & 39.6 \\ \text { All fish (WB) } & 10 & \text { Composite } & - & - & 78.9 & 19.5 \\ \text { NCBP-All fish } & - & \text { Composite } & - & - & 75.0 & 2.9\end{array}$

\section{Bird eggs}

$\begin{array}{lllrrrr}\text { Black-necked stilt } & 3 & \text { Individual } & 47 & 20 & 74.1 & 8.8 \\ \text { Common snipe } & 1 & \text { Individual } & 31 & 9 & 77.4 & 5.8\end{array}$

\section{Plants}

Blue-green algae
Filamentous green algae
Duckweed
Potamogeton
Widgeongrass
Hardstem bulrush
Hardstem bulrush (seed)
Cattail

Chironomidae

Hemiptera

1
2
1
1
2
7
1
4

Composite
Composite
Composite
Composite
Composite
Composite
Composite
Composite

$\begin{array}{ll}- & - \\ - & - \\ - & - \\ - & - \\ - & - \\ - & -\end{array}$

\section{Invertebrates}

70.4

87.3

93.0

92.1

87.5

77.6

7.8

86.1

${ }^{1} 2.1$

9.3

41.4

${ }^{1} 27.0$

20.3

2.9

0.98

8.8

${ }^{1}$ Data from Stephens and others, 1988a

tially larger selenium concentrations when taken from along the north shore compared to the south shore (ALS 0.01). Selenium concentrations in black bullhead, however, were not significantly different.

Tissue residue for combined fish species collected along the north shore and south shore of Stewart Lake were compared to residue for fish collected at a site immediately downstream (within $300 \mathrm{ft}$ ) of the lake outlet structure in the channel leading from Stewart Lake to the Green River. Water from this channel normally represents water from Stewart Lake except when the Green River has 
Table 12. Geometric mean selenium concentrations in fish samples collected from the north and south shores of Stewart Lake and the outlet to the Green River, and in fish samples collected nationwide by the National Contaminant Biomonitoring Program

[WB, whole body; MS, muscle; J2, J3, J4, the combined channel of drains J2, J3, and J4; mm, millimeter; g, gram; $\mu \mathrm{g} / \mathrm{g}$, micrograms per gram (dry weight); -, not specified. NCBP, National Contaminant Biomonitoring Program, from Schmitt and Brumbaugh, 1990 (1984 geometric mean concentration, 85 th percentile, converted to dry weight using 75 percent moisture). Mean length, weight, and moisture content are arithmetic means]

\begin{tabular}{ccccccc}
\hline Organism & $\begin{array}{c}\text { Sample } \\
\text { type }\end{array}$ & $\begin{array}{c}\text { Sample } \\
\text { size }\end{array}$ & $\begin{array}{c}\text { Mean } \\
\text { length } \\
(\mathrm{mm})\end{array}$ & $\begin{array}{c}\text { Mean } \\
\text { weight } \\
(\mathrm{g})\end{array}$ & $\begin{array}{c}\text { Mean } \\
\text { moisture } \\
\text { content } \\
(\text { percent })\end{array}$ & $\begin{array}{c}\text { Geometric } \\
\text { mean selenium } \\
\text { concentration } \\
(\mu \mathrm{g} / \mathrm{g})\end{array}$ \\
\hline
\end{tabular}

\section{North shore}

$\begin{array}{llrrrrc}\text { Black bullhead (WB) } & \text { Composite } & 4 & 182 & 72 & 82.3 & 20.6 \\ \text { Catfish (WB) } & \text { Individual } & 1 & 455 & 773 & 83.6 & 22 \\ \text { Common carp (WB) } & \text { Composite } & 8 & 338 & 490 & 76.2 & 47.9 \\ \text { All fish (WB) } & \text { Composite, Individual } & 13 & - & - & 78.6 & 34.8\end{array}$

\section{South shore}

$\begin{array}{lc}\text { Black bullhead (WB) } & \text { Composite } \\ \text { Catfish (MS) } & \text { Individual } \\ \text { Catfish (WB) } & \text { Individual } \\ \text { Common carp (MS) } & \text { Individual } \\ \text { Common carp (WB) } & \text { Composite } \\ \text { Green sunfish (WB) } & \text { Individual } \\ \text { White sucker (WB) } & \text { Composite } \\ \text { All fish (WB) } & \text { Composite, } \\ & \text { Individual }\end{array}$

$\begin{array}{rrrrr}9 & 164 & \mathbf{5 7} & 80.8 & 16.1 \\ 3 & 527 & - & 76.9 & 12.0 \\ 1 & 445 & 834 & 79.2 & 9.1 \\ 5 & 296 & - & 81.1 & 27.6 \\ 13 & 334 & 478 & 76.8 & 29.3 \\ 1 & 42 & 100 & 77.2 & 126 \\ 1 & 238 & 143 & 75.2 & 19.2 \\ 25 & - & - & 78.3 & 22.1\end{array}$

\section{Downstream of outlet}

$\begin{array}{lr}\text { Black bullhead (WB) } & \text { Composite } \\ \text { Common carp (WB) } & \text { Composite } \\ \text { Fathead minnow (WB) } & \text { Composite } \\ \text { Green sunfish (WB) } & \text { Composite } \\ \text { All fish (WB) } & \text { Composite }\end{array}$

$\begin{array}{rrr}1 & 118 & 23 \\ 1 & 393 & 676 \\ 1 & - & 4 \\ 1 & 108 & 28 \\ 4 & - & -\end{array}$

77.3

$78.6 \quad 14.7$

Combined channel J2, J3, J4

$\begin{array}{lllllll}\text { Common carp (WB) } & \text { Composite } & 1 & 304 & 363 & 80.1 & 83.9 \\ \text { All fish, NCBP } & \text { Composite } & - & - & - & 75.0 & 2.9\end{array}$

\footnotetext{
${ }^{1}$ Data from Stephens and others, 1988a
} 
large flows and creates a backwater condition in the channel. Fish collected from the north and south shore sites had significantly larger selenium concentrations than fish collected from the outflow channel (ALS 0.01, 0.05, respectively). Species composition of fish collected downstream from the outlet structure was different from those collected in Stewart Lake; however, carp and bullhead samples (which dominated the north and south shore sites) were included and were similar to the geometric mean for this site.

The only other statistically significant (Mann-Whitney test) relations found in element residues from fish tissues from different sites at Stewart Lake were for aluminum and manganese. Whole-body concentrations of aluminum and manganese in black bullheads collected from the south shore of Stewart Lake were larger than concentrations in black bullheads collected near the north shore of the lake (for aluminum: ALS 0.05; for manganese: ALS 0.02).

Concentrations of aluminum and iron in sediment were slightly larger at the outflow (south shore) than at the drains at Stewart Lake (Stephens and others, 1988a, table 13), but data were not

Table 13. Geometric mean selenium concentrations in whole-body adult fish samples collected at several locations in Stewart Lake during spring and summer and in fish samples collected nationwide by the National Contaminant Biomonitoring Program

[mm, millimeter; g, gram; $\mu \mathrm{g} / \mathrm{g}$, microgram per gram (dry weight); NS, north shore; SS, south shore; -, not specified. NCBP, National Contaminant Biomonitoring Program, from Schmitt and Brumbaugh, 1990 (1984 geometric mean concentration, 85th percentile, converted to dry weight using 75 percent moisture). Mean length, weight, and moisture content are arithmetic means]

\begin{tabular}{cccccccc}
\hline Species & Sample & Sample & Site \\
size & type & name & $\begin{array}{c}\text { Mean } \\
\text { length } \\
(\mathrm{mm})\end{array}$ & $\begin{array}{c}\text { Mean } \\
\text { weight } \\
(\mathrm{g})\end{array}$ & $\begin{array}{c}\text { Mean } \\
\text { moisture } \\
\text { content } \\
(\mathrm{percent})\end{array}$ & $\begin{array}{c}\text { Geometric } \\
\text { mean selenium } \\
\text { concentration } \\
(\mu \mathrm{g} / \mathrm{g})\end{array}$ \\
\hline
\end{tabular}

\begin{tabular}{|c|c|c|c|c|c|c|c|}
\hline Black bullhead & 1 & Composite & NS & 184 & 74 & 81.0 & 19.5 \\
\hline Common carp & 3 & Composite & NS & 347 & 526 & 75.3 & 53.4 \\
\hline Black bullhead & 4 & Composite & SS & 206 & 60 & 81.3 & 15.2 \\
\hline Common carp & 6 & Composite & SS & 319 & 424 & 77.0 & 28.8 \\
\hline White sucker & 1 & Composite & SS & 238 & 143 & 75.2 & 19.2 \\
\hline All fish-Spring & 15 & Composite & NS/SS & - & - & 77.9 & 26.0 \\
\hline \multicolumn{8}{|c|}{ Summer collections } \\
\hline Black bullhead & 3 & Composite & NS & 123 & 68 & 83.0 & 19.8 \\
\hline Channel catfish & 1 & Individual & NS & 455 & 773 & 83.6 & 22 \\
\hline Common carp & 5 & Composite & NS & 332 & 468 & 76.8 & 44.8 \\
\hline Black bullhead & 4 & Composite & SS & 163 & 55 & 79.1 & 12.6 \\
\hline Channel catfish & 1 & Individual & SS & 445 & 834 & 79.2 & 9.1 \\
\hline Common carp & 7 & Composite & SS & 346 & 524 & 76.7 & 29.8 \\
\hline Green sunfish & 1 & Individual & SS & 100 & 100 & 77.2 & $1_{26}$ \\
\hline All fish-Summer & 22 & Composite, Individual & NS/SS & - & - & 78.5 & 24.6 \\
\hline All fish-NCBP & - & Composite & - & - & - & 75.0 & 2.9 \\
\hline
\end{tabular}

Spring collections

\footnotetext{
${ }^{1}$ Data from Stephens and others, 1988a
} 
available for manganese. The presence of bottom material mixed with food may account for the difference between sites. Small samples of invertebrates suggest that concentrations of aluminum, iron, and manganese were larger in mixed invertebrates from the south shore than from the north shore. The concentration of manganese in these invertebrates is much less than is known to be toxic to fish in their diet (Gough and others, 1979).

Included in the statistical analysis was a single composite sample of black bullhead fry collected near the outlet on the south shore. This sample had a selenium concentration of $56.1 \mu \mathrm{g} / \mathrm{g} \mathrm{dry}$ weight and had considerable influence on the statistical analysis. Only samples of carp from sites closer to the drains had larger selenium concentrations than at Stewart Lake. This sample also exerted considerable influence on the calculated level of aluminum. The aluminum concentration in this sample was $74.3 \mu \mathrm{g} / \mathrm{g}$. The remaining samples of black bullhead from the south side of Stewart Lake had aluminum concentrations ranging from $<60.6 \mu \mathrm{g} / \mathrm{g}$ to $1,150 \mu \mathrm{g} / \mathrm{g}$. Only two of the nine samples from the south shore had smaller concentrations than $405 \mu \mathrm{g} / \mathrm{g}$. The samples of black bullhead from the north shore ranged from $127 \mu \mathrm{g} / \mathrm{g}$ to $369 \mu \mathrm{g} / \mathrm{g}$. Had the sample of black bullhead fry been excluded from the calculations, the comparison for aluminum between sites on the lake would have been even more pronounced. It is likely that the sample of fry is different from the other samples because of food habits and growth stage.

Concentrations of residues in adult fish also were examined for seasonal variation. There was no significant difference between the selenium concentrations (ALS 0.05) in fish collected in the spring (geometric mean $26.0 \mu \mathrm{g} / \mathrm{g}$ ) and in mid-summer (geometric mean $24.6 \mu \mathrm{g} / \mathrm{g}$ ) (table 13). Similarly, no significant difference was found for zinc concentrations (ALS 0.02). The interpretation of data for other elements was hindered by large numbers of samples having concentrations less than the reporting limits. Examination of the data for boron and mercury suggested larger concentrations occurred in the summer than in the spring, and conversely, aluminum concentrations were larger in spring.

Fish collected at marsh 4720 had selenium concentrations similar to those collected from the south shore of Stewart Lake. Geometric mean selenium concentrations were $26.2 \mu \mathrm{g} / \mathrm{g}$ for common carp and $12.6 \mu \mathrm{g} / \mathrm{g}$ for black bullhead (table 11).

One 4.4-kg channel catfish (Ictalurus punctatus) was captured at Stewart Lake on April 13, 1989. This fish was lethargic and covered with red lesions. Necropsy at the USFWS Fish Diseases Control Center found no apparent internal diseases. Although the Center was uncertain if bacteria or parasites were the primary cause of the external lesions, it was believed that the fish was under chronic stress, a condition healthy fish rarely experience (P.J. Barney, written commun., 1990). Selenium concentrations in the liver and muscle tissues of this fish were 41.8 and $12.7 \mu \mathrm{g} / \mathrm{g}$, respectively (Peltz and Waddell, 1991, p. 107).

\section{Residue in Plants}

Plant samples were collected from Stewart Lake close to the outlet structure (south shore), near the confluence of the J1 and J1A drains, in the common channel for the J3 and J4 drains, and at the outlet of the J4 drain. Some plants were also collected near the north shore of the main body of Stewart Lake in the area where the combined flow of the J2, J3, and J4 drains and several seeps enters the main lake. Geometric mean concentrations of selenium in plants are shown in table 14 by site collected for each taxonomic group. Selenium concentrations for individual samples of non-emergent aquatic plants (excludes algae) ranged from $4.44 \mu \mathrm{g} / \mathrm{g}$ for horned pondweed (Zannichellia palustris) to $73 \mu \mathrm{g} / \mathrm{g}$ for widgeongrass (Ruppia maritima) (Peltz and Waddell, 1991, p. 93).

Selenium concentrations were substantially larger in cattails collected near the J3 and J4 drains (geometric means of 17.9 and $22.3 \mu \mathrm{g} / \mathrm{g}$ ) than in the main body of Stewart Lake (geometric means of 2.4 and $3.2 \mu \mathrm{g} / \mathrm{g}$ for north shore and south shore samples). When all non-emergent aquatic plants including duckweed (Lemna spp.) were grouped, selenium concentrations were substantially larger in plants collected near the J3 and J4 drains (with a geometric mean of $32.7 \mu \mathrm{g} / \mathrm{g}$ ) than in those 
Table 14. Geometric mean selenium concentrations in composite samples of plants and invertebrates collected from Stewart Lake

[ $\mu \mathrm{g} / \mathrm{g}$, micrograms per gram (dry weight); drains, J1, J1A, J3, J4; SS, south shore; NS, north shore. Mean moisture content is an arithmetic mean]

\begin{tabular}{|c|c|c|c|c|}
\hline Organism & $\begin{array}{c}\text { Site } \\
\text { name }\end{array}$ & $\begin{array}{l}\text { Sample } \\
\text { size }\end{array}$ & $\begin{array}{c}\text { Mean } \\
\text { moisture } \\
\text { content } \\
\text { (percent) }\end{array}$ & $\begin{array}{c}\text { Geometric } \\
\text { mean selenium } \\
\text { concentration } \\
(\mu \mathrm{g} / \mathrm{g})\end{array}$ \\
\hline \multicolumn{5}{|c|}{ Plants } \\
\hline $\begin{array}{l}\text { Blue-green algae } \\
\text { Filamentous green algae }\end{array}$ & $\begin{array}{l}\text { J1,J1A } \\
\text { SS } \\
\text { J1,J1A } \\
\text { J3 } \\
\text { J4 }\end{array}$ & $\begin{array}{l}1 \\
2 \\
5 \\
2 \\
4\end{array}$ & $\begin{array}{l}76.3 \\
89.3 \\
85.0 \\
81.9 \\
79.1\end{array}$ & $\begin{array}{r}{ }^{1} 24 \\
8.7 \\
1.4 \\
4.7 \\
2.7\end{array}$ \\
\hline Duckweed & J4 & 4 & 93.7 & 26.9 \\
\hline Potamogeton & $\begin{array}{l}\text { SS } \\
\text { J1,J1A } \\
\text { J3 }\end{array}$ & $\begin{array}{l}1 \\
1 \\
1\end{array}$ & $\begin{array}{l}86.8 \\
90.5 \\
85.6\end{array}$ & $\begin{array}{l}6.77 \\
{ }_{1} 13.0 \\
{ }^{1} 21\end{array}$ \\
\hline Widgeongrass & J3 & 4 & 88.9 & 31.9 \\
\hline Hardstem bulrush & $\begin{array}{l}\text { SS } \\
\text { J1,J1A } \\
\text { J3 }\end{array}$ & $\begin{array}{l}4 \\
4 \\
4\end{array}$ & $\begin{array}{l}83.9 \\
85.4 \\
82.8\end{array}$ & $\begin{array}{l}2.9 \\
2.4 \\
8.1\end{array}$ \\
\hline Hardstem bulrush (seed) & $\begin{array}{l}\text { SS } \\
\text { J4 }\end{array}$ & $\begin{array}{l}1 \\
1\end{array}$ & $\begin{array}{l}13.6 \\
20.5\end{array}$ & $\begin{array}{l}.93 \\
.50\end{array}$ \\
\hline Cattail & $\begin{array}{l}\text { NS } \\
\text { SS } \\
\text { J1,J1A } \\
\text { J3 } \\
\text { J3,J4 } \\
\text { J4 }\end{array}$ & $\begin{array}{l}2 \\
8 \\
4 \\
7 \\
2 \\
4\end{array}$ & $\begin{array}{l}86.5 \\
88.3 \\
88.4 \\
85.9 \\
88.4 \\
86.3\end{array}$ & $\begin{array}{r}2.4 \\
3.2 \\
4.3 \\
17.9 \\
7.1 \\
22.3\end{array}$ \\
\hline Cattail (seed) & $\begin{array}{l}\text { SS } \\
\text { J4 }\end{array}$ & $\begin{array}{l}1 \\
1\end{array}$ & $\begin{array}{l}44.4 \\
51.0\end{array}$ & $1^{.36}$ \\
\hline Horned pondweed & $\begin{array}{l}\text { J1,J1A } \\
\text { J3 } \\
\text { J4 }\end{array}$ & $\begin{array}{l}3 \\
1 \\
4\end{array}$ & $\begin{array}{l}91.7 \\
92.0 \\
92.6\end{array}$ & $\begin{array}{l}6.9 \\
58 \\
39.3\end{array}$ \\
\hline \multicolumn{5}{|c|}{ Invertebrates } \\
\hline Chironomidae & SS & 1 & 86.8 & 27 \\
\hline Corixidae & $\begin{array}{l}\text { SS } \\
\text { SS,J1,J1A,J3,J4 }\end{array}$ & $\begin{array}{l}1 \\
1\end{array}$ & $\begin{array}{l}88.6 \\
87.4\end{array}$ & $\begin{array}{l}13.2 \\
13.5\end{array}$ \\
\hline Hemiptera & J3 & 1 & 58.7 & 37.4 \\
\hline Mixed invertebrates & $\begin{array}{l}\text { NS } \\
\text { SS }\end{array}$ & $\begin{array}{l}1 \\
4\end{array}$ & $\begin{array}{l}76.9 \\
70.5\end{array}$ & $\begin{array}{l}17.8 \\
12.6\end{array}$ \\
\hline
\end{tabular}

${ }^{1}$ Data from Stephens and others, 1988a 
collected at all other sites (geometric mean $7.8 \mu \mathrm{g} / \mathrm{g}$ ) combined (ALS 0.01). Two samples of filamentous green algae collected near the south shore of Stewart Lake had significantly larger selenium concentrations than 11 similar samples collected near all drains combined (ALS 0.04).

Generally, selenium concentrations were progressively smaller in cattails collected from sites following the order: J4 drain > J3 drain > combined channel for J4 and J3 drains > main body of Stewart Lake. This order may be a result of biogeochemical uptake of dissolved selenium and its removal from water near the outfalls of the $\mathrm{J} 3$ and $\mathrm{J} 4$ drains and possibly dilution of dissolved selenium by water from the J2 drain that typically contained less selenium than the J3 or J4 drains. Selenium concentrations in cattails near the $J 1$ drain were slightly larger than concentrations in cattails from the main body of Stewart Lake.

Selenium concentrations in cattail root and stem correlated quite well with concentrations in bottom sediment from Stewart Lake. Results of transect sampling of sediment and cattail with distance lakeward from the discharge of the J3 drain are shown in figure 33 and indicate that cattails growing in seleniferous bottom sediment incorporate a proportionate quantity of the selenium into plant tissue. Concentrations in cattail were relatively small at a point $26 \mathrm{ft}$ from the outfall of the drain, reached a maximum in the sample at $60 \mathrm{ft}$, and declined to the last sample at 2,600 ft. The pattern in bottom sediment was similar with the exception that the maximum selenium concentration occurred at $350 \mathrm{ft}$. (The selenium concentration in the sediment from $350 \mathrm{ft}$ was reconfirmed by the laboratory.) The selenium concentrations in bottom sediment and cattails did not appear related to concentrations of inorganic or organic carbon in the sediment (table 15); however, the possibly anomalous selenium concentration in sediment from the site at $350 \mathrm{ft}$ was associated with the largest concentration of inorganic carbon measured in any of the sediment samples. The selenium concentration in water at the point of discharge from the J3 drain was $75 \mu \mathrm{g} / \mathrm{L}$. The concentration $150 \mathrm{ft}$ from the discharge had declined to $66 \mu \mathrm{g} / \mathrm{L}$.

Cattails collected in the main body of Stewart Lake (north and south shore sites combined) had significantly larger aluminum concentrations (geometric mean of $2,030 \mu \mathrm{g} / \mathrm{g}$ ) than cattails collected and grouped $(564 \mu \mathrm{g} / \mathrm{g}$ ) from drain sites (ALS 0.01). The source of the aluminum and its biological significance is not known.

Geometric mean selenium concentrations in plant tissue from marsh 4720 are shown in table 11. In 1986, samples were collected in the main body of the marsh near the inlet of the tributaries. Samples collected in 1988 were collected near the points of inflow of the tributaries to marsh 4720 due to reduced water levels in the wetland. Non-emergent aquatic plants (potamogeton, widgeongrass, and duckweed) had larger geometric mean selenium concentrations than emergent plants.

Selenium concentrations at Stewart Lake and marsh 4720 in non-emergent aquatic plants exceed the 4 to $8 \mu \mathrm{g} / \mathrm{g}$ selenomethionine concentration in diets associated with reduced reproductive success of mallards (Heinz and others, 1989) and exceed the $16 \mu \mathrm{g} / \mathrm{g}$ selenium level (as selenomethionine) that produced at least one malformed mallard embryo per clutch of eggs. Athough the chemical form of selenium present in plants from Stewart Lake is not known, waterbirds feeding on these plants are likely to have reduced reproductive success and higher rates of malformed embryos.

\section{Residue in Invertebrates}

Invertebrates were collected using light traps and by removing stomach contents of black bullheads. Selenium concentrations in invertebrate samples from Stewart Lake and marsh 4720 combined ranged from 10.4 to $37.4 \mu \mathrm{g} / \mathrm{g}$ (Peltz and Waddell, 1991, p. 93, 111). A chironomid sample $(27.0 \mu \mathrm{g} / \mathrm{g})$ and two composite samples of Hemiptera collected near the J3 drain $(37.4 \mu \mathrm{g} / \mathrm{g})$ and at marsh $4720(26.5 \mu \mathrm{g} / \mathrm{g})$ contained the largest selenium concentrations. The chironomid sample was recovered from a composite of black bullhead stomachs. In general, of all the areas studied within the Middle Green River basin, Stewart Lake was the most difficult area in which to obtain an adequate biomass of invertebrates for a sample. 


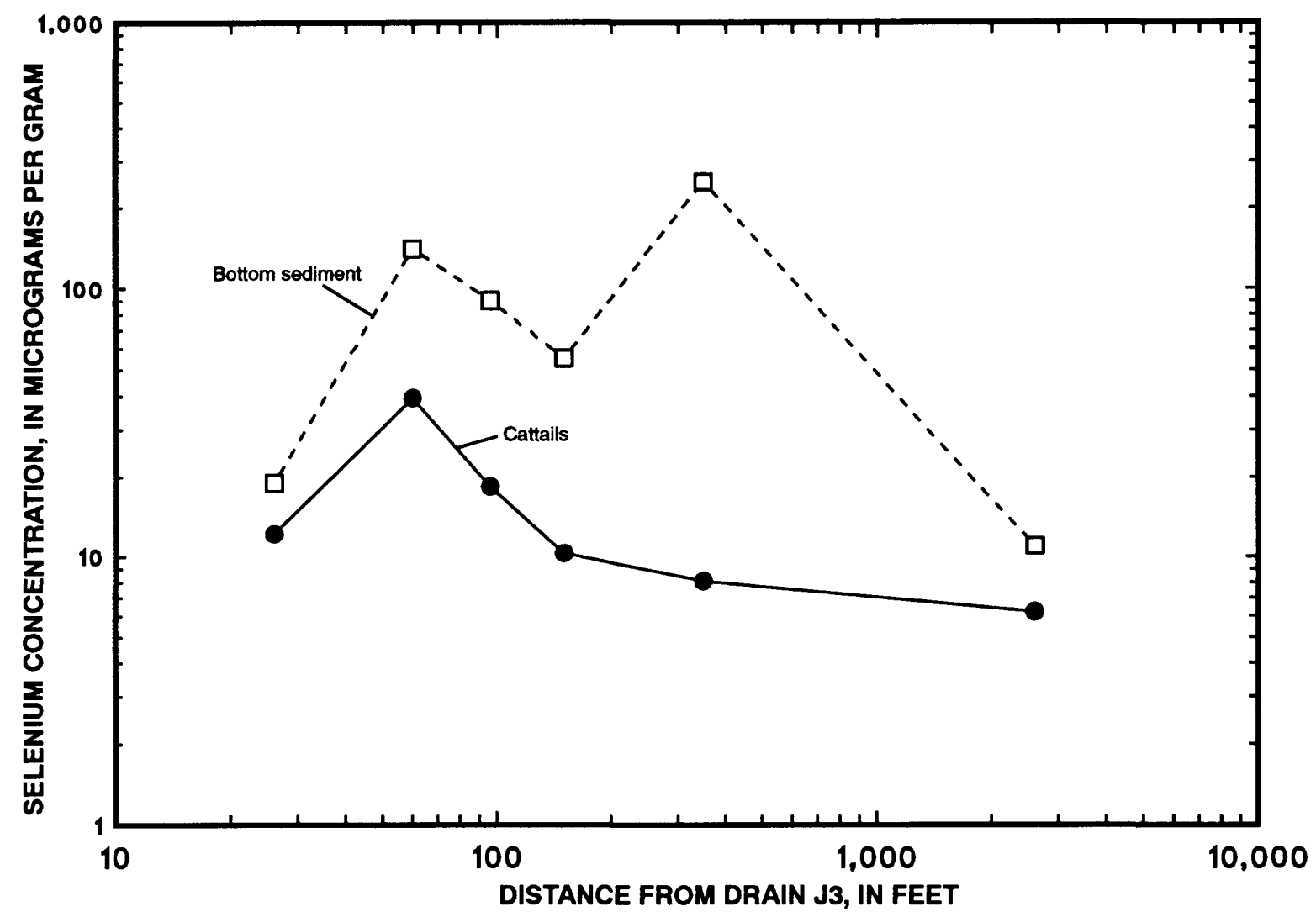

Figure 33. Selenium concentrations in bottom sediment and cattails at several distances from the outfall of drain J3 at Stewart Lake.

Table 15. Selenium concentrations in water, bottom sediment, and stems and roots of cattail (Typha sp.), and sediment carbon in samples collected at several distances from the outfall of the J3 drain at Stewart Lake

[ $\mu \mathrm{g} / \mathrm{L}$, micrograms per liter; $\mu \mathrm{g} / \mathrm{g}$, micrograms per gram; g/kg, grams per kilogram; —, no data]

\begin{tabular}{|c|c|c|c|c|c|}
\hline \multirow[b]{2}{*}{$\begin{array}{l}\text { Distance from outfall } \\
\text { (feet) }\end{array}$} & \multicolumn{3}{|c|}{ Selenium } & \multicolumn{2}{|c|}{ Sediment carbon } \\
\hline & $\begin{array}{l}\text { Water } \\
(\mu \mathrm{g} / \mathrm{L})\end{array}$ & $\begin{array}{l}\text { Sediment } \\
(\mu \mathrm{g} / \mathrm{g})\end{array}$ & $\begin{array}{c}\text { Cattail } \\
(\mu \mathrm{g} / \mathrm{g})\end{array}$ & $\begin{array}{c}\text { Inorganic } \\
(\mathrm{g} / \mathrm{kg})\end{array}$ & $\begin{array}{c}\text { Organic } \\
(\mathrm{g} / \mathrm{kg})\end{array}$ \\
\hline 0 & 75 & - & - & - & - \\
\hline 26 & - & 19 & 12.2 & 12 & 22 \\
\hline 60 & - & 140 & 39.3 & 25 & 43 \\
\hline 96 & - & 90 & 18.4 & 26 & 62 \\
\hline 150 & 66 & 55 & 10.3 & 35 & 85 \\
\hline 350 & - & 250 & 8.1 & 61 & 49 \\
\hline 2,600 & - & 11 & 6.2 & 34 & 16 \\
\hline
\end{tabular}




\title{
HYDROLOGY AND CONTAMINANTS IN BIOTA IN THE ASHLEY CREEK AREA
}

\author{
Hydrology and Water Quality
}

Selenium contamination in Ashley Creek was first reported by Stephens and others (1988a, p. 43), who calculated that on the basis of data from June 1986, a daily load of $8 \mathrm{~kg}$ of selenium was discharged from Ashley Creek to the Green River. The selenium load from Ashley Creek was nearly as large as the load contributed by the Yampa River, which has an average daily water discharge 30 times larger than Ashley Creek. Bottom material in Ashley Creek near U.S. Highway 40 contained a selenium concentration of $7.1 \mu \mathrm{g} / \mathrm{g}$, or greater than 10 times the average concentration found in soils in the area (Stephens and others, 1988a, table 12). Although a detailed study was not done on Ashley Creek, water samples were collected at sites shown in figure 34 on Ashley Creek and its inflows in 1988-89, and sources of selenium contamination to Ashley Creek were identified.

Water samples were collected from 11 of the USBOR drains in the Vernal area believed to be representative of the $19 \mathrm{mi}$ of drains installed in the area ( 25 drains in use in 1990). Locations of the drains and selenium concentrations in water from 11 selected drains are shown in figure 35 . Selenium concentrations in the drains did not exceed $13 \mu \mathrm{g} / \mathrm{L}$ and had a mean of $4.5 \mu \mathrm{g} / \mathrm{L}$.

Virtually all of the selenium contamination enters Ashley Creek south of 500 North Street in Vernal (river mile 16.95). Sampling of tributaries in 1988-89 identified water sources containing selenium concentrations ranging from $<1$ to $16,000 \mu \mathrm{g} / \mathrm{L}$ (table 16 ). Seventy percent of the 23 tributaries and seeps that were sampled contained water with selenium concentrations that exceeded the State wildlife protection standard of $5 \mu \mathrm{g} / \mathrm{L}$. The area contributing the largest concentrations was immediately downgradient of the Vernal sewage lagoons and the Winter Storage Pond associated with the lagoons. Because there is no surface discharge from the 307-acre lagoon system, once the lagoons are filled, water is lost only through evaporation and seepage.

Inflow to the lagoons totaled 3,543 acre-ft in 1987. Potential evaporation for the same period could have removed about 1,100 acre-ft, indicating that over 2,400 acre-ft of water could have leaked from the lagoons in 1987. Sites of seepage downgradient of the sewage lagoons and the Winter Storage Pond and the selenium concentration found at each site are shown in figure 34. The largest selenium concentration $(16,000 \mu \mathrm{g} / \mathrm{L})$ found in any water sample during the 1986-89 DOI study in the middle Green River basin occurred in seepage discharged directly to Ashley Creek at river mile 8.5 downgradient of the lagoons and Winter Storage Pond.

The Winter Storage Pond was constructed in 1981 to store overflow from the lagoons in winter when evaporation rates are small. The Winter Storage Pond contained a large volume of water when sampled in 1988-89. No water was observed entering the pond during several trips to the area in 1989 , although the pond can receive surface inflow from the north. The surface outlet from the lagoons did not appear to have been used to move water from the lagoons into the Winter Storage Pond. Likely, most of the water in the Winter Storage Pond enters as seepage from the lagoons, 20-30 ft upgradient.

There was considerable leakage from the lagoons and, as a result, the waste-water treatment district had to purchase farms directly downgradient that became unusable due to flooding caused by seepage from the lagoons (Christine Horting, Utah Bureau of Water Pollution Control, oral commun., 1988). There was virtually no selenium in the water in the lagoons in September 1988, but water from the Winter Storage Pond contained $9 \mu \mathrm{g} / \mathrm{L}$ of selenium. The source of the selenium is the soils and Mancos Shale of the hillside bench on which the lagoons and the Winter Storage Pond are constructed. Prior to construction of the lagoon system, there was little or no water on the bench to act as recharge. A 1965 topographic map shows the only spring in the area to be $1.5 \mathrm{mi}$ north of the lagoons, and water from this spring contained only $3 \mu \mathrm{g} / \mathrm{L}$ of selenium when sampled in 1988 . It is likely that the lagoons and Winter Storage Pond recharge water that subsequently flows through highly seleniferous deposits of Mancos Shale before discharging to Ashley Creek at the base of the hill. Because the lagoon system 


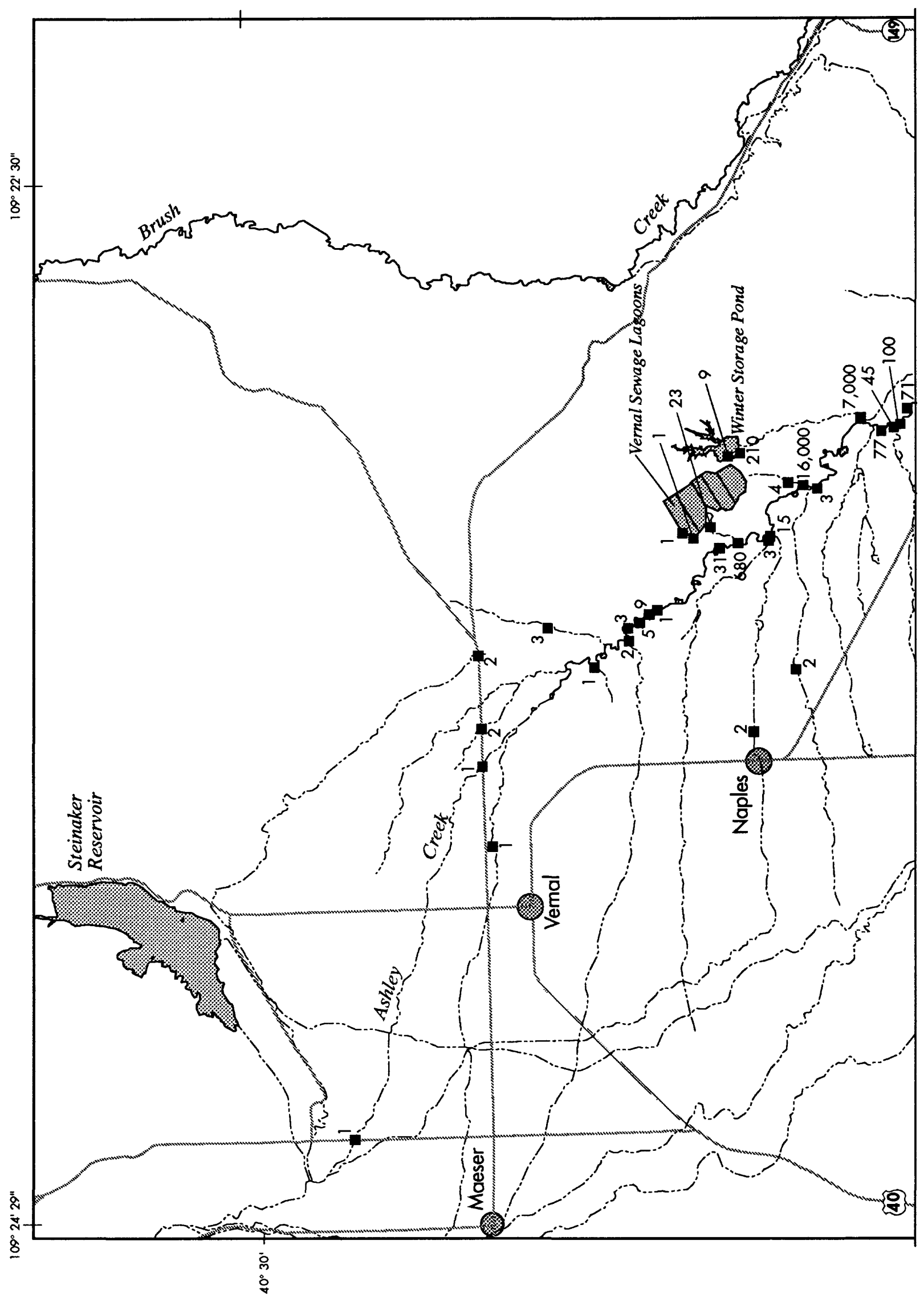




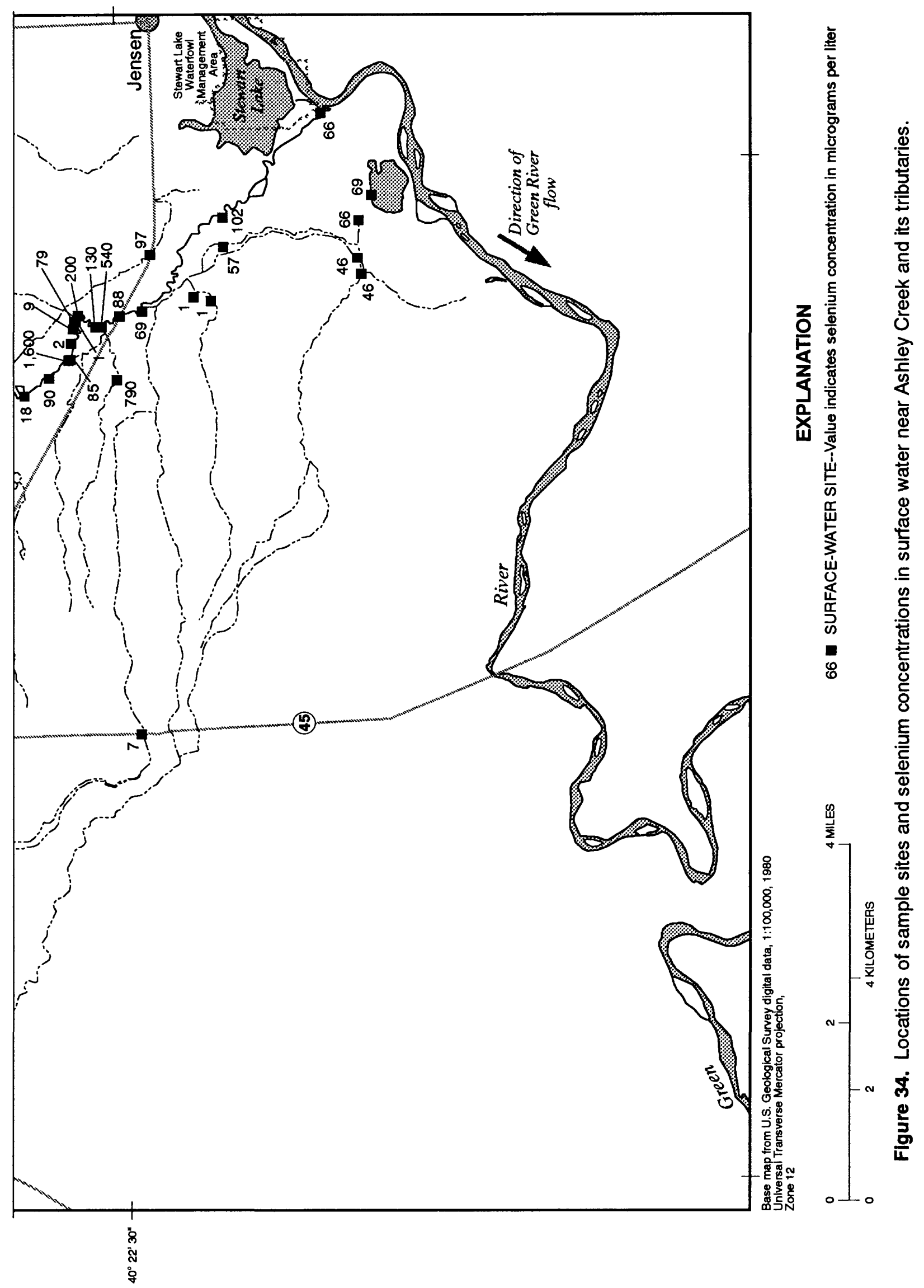


is relatively recent in construction (1981), the time interval for selenium leaching has been short. Selenium in the flow path of recharge for the older spring to the north may have been leached from the soil.

Selenium concentrations in Ashley Creek at 500 North Street upstream of the Vernal drains and the sewage lagoons were generally less than $1 \mu \mathrm{g} / \mathrm{L}$. Concentrations in Ashley Creek at U.S. Highway 40 averaged $73 \mu \mathrm{g} / \mathrm{L}$ ( 7 samples) and 2 mi downstream at the county road in Jensen averaged $93 \mu \mathrm{g} / \mathrm{L}$ ( 2 samples). Water is diverted from Ashley Creek near U.S. Highway 40 into the Union Canal and is then used for irrigation and stock watering in Jensen. Water in the Union Canal at the point of diversion contained a selenium concentration of $69 \mu \mathrm{g} / \mathrm{L}$ during sampling in June 1989 . The Union Canal splits into the Poulton Canal and the Lower Union Canal, and the Lower Union Canal provideswater for marsh 4720 just west of Stewart lake. The mean selenium concentration in six water samples from the Lower Union Canal near the marsh was $73 \mu \mathrm{g} / \mathrm{L}$. Selenium concentrations in water entering the marsh have ranged from 26 to $130 \mu \mathrm{g} / \mathrm{L}$. Boron concentrations in the inflow to marsh

Table 16. Concentrations of dissolved selenium in tributaries discharging to Ashley Creek downstream of Steinaker Draw

[River mile is distance from the confluence of Ashley Creek and the Green River; $\mu \mathrm{g} / \mathrm{L}$, micrograms per liter; $\mathrm{ft}^{3} / \mathrm{s}$, cubic feet per second; -, not measured; S., south]

\begin{tabular}{|c|c|c|c|c|}
\hline Site & $\begin{array}{l}\text { River } \\
\text { mile }\end{array}$ & Date & $\begin{array}{l}\text { Selenium concentration } \\
(\mu \mathrm{g} / \mathrm{L})\end{array}$ & $\begin{array}{l}\text { Discharge } \\
\left(\mathrm{ft}^{3} / \mathrm{s}\right)\end{array}$ \\
\hline Mantle Gulch at Ashley Creek & 4.9 & $07-13-88$ & 540 & - \\
\hline Tributary 2 & 5.0 & $07-13-88$ & 130 & - \\
\hline Tributary 3 & 5.4 & $07-13-88$ & 200 & - \\
\hline Tributary 4 & 5.5 & $07-13-88$ & 79 & - \\
\hline Tributary 5 & 5.6 & $07-13-88$ & 1 & - \\
\hline Tributary 6 & 5.7 & $07-13-88$ & 9 & - \\
\hline Tributary 7 & 6.1 & $07-13-88$ & 2 & - \\
\hline Tributary 8 & 6.3 & $07-13-88$ & 1,600 & - \\
\hline Tributary 11 & 7.0 & $07-13-88$ & 18 & - \\
\hline Tributary 12 & 7.6 & $07-13-88$ & 71 & - \\
\hline Tributary 14 & 7.9 & $09-27-88$ & 45 & 0.37 \\
\hline \multirow[t]{3}{*}{ Sunshine/Burns runoff } & 8.4 & $07-14-88$ & 3,800 & - \\
\hline & & $09-27-88$ & 8,300 & .06 \\
\hline & & $09-27-88$ & 8,900 & .06 \\
\hline Sunshine mancos seep & 8.5 & $08-22-89$ & 16,000 & - \\
\hline Tributary 4930 & 10.0 & $08-22-89$ & 14 & 1.0 \\
\hline Ashley Central Canal & 11.1 & $09-28-88$ & 15 & .05 \\
\hline Naples drain & 11.1 & $09-28-88$ & 3 & .87 \\
\hline Abandoned farm drain & 11.8 & $09-28-88$ & 530 & .50 \\
\hline Farm drain 1550 S. Naples & 13.6 & $09-27-88$ & 9 & .36 \\
\hline Drain 2 , S. of S. Vernal drain & 13.7 & $09-27-88$ & 5 & .19 \\
\hline Drain $1, \mathrm{~S}$. of S. Vernal drain & 13.8 & $09-27-88$ & 3 & .96 \\
\hline South Vernal drain & 14.1 & $09-27-88$ & 2 & 1.3 \\
\hline Ingram drain (golf course) & 14.8 & $09-27-88$ & $<1$ & .48 \\
\hline North Vernal drain & 16.4 & 08-23-89 & $<1$ & 1.4 \\
\hline
\end{tabular}




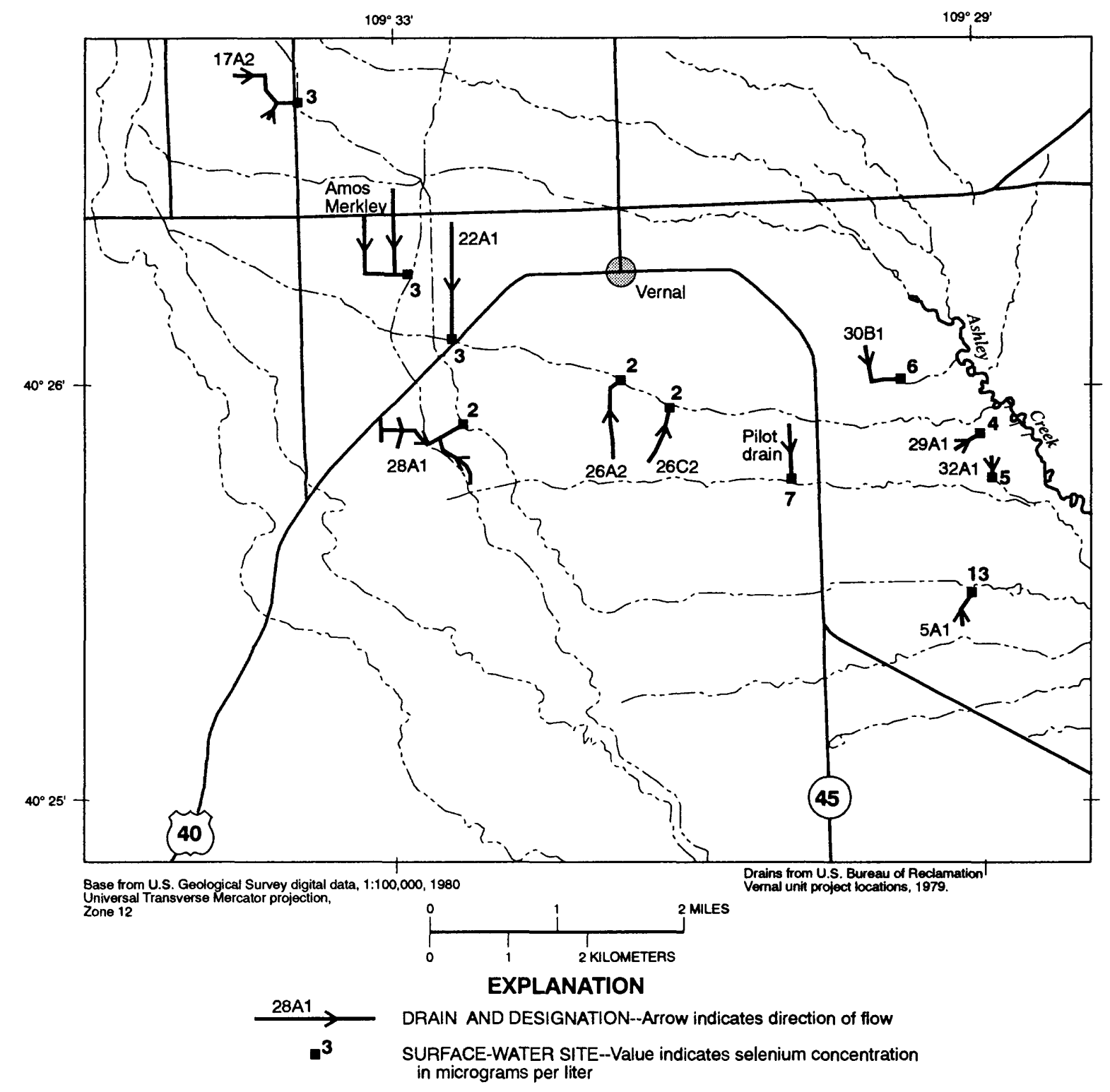

Figure 35. Locations of 11 of the 25 U.S. Bureau of Reclamation drains in the Vernal, Utah, area and selenium concentrations in water from selected drains.

4720 have been as large as $1,500 \mu \mathrm{g} / \mathrm{L}$. The selenium concentration in the marsh during a massive fish kill resulting from a lack of water in September 1988 was $7 \mu \mathrm{g} / \mathrm{L}$, and boron was 8,800 $\mu \mathrm{g} / \mathrm{L}$. Formation water (likely from the Weber Sandstone) produced from the Ashley Oil Field is also discharged to the Union Canal and is used for irrigation during the summer and stock watering during the winter. While the dissolved-solids concentration in the formation water was large (1,300-1,900 $\mathrm{mg} / \mathrm{L}$ ), analyses of water from two oil wells indicated that it contained no selenium.

The Poulton Canal receives water from the Union Canal south of its diversion from Ashley Creek near U.S. Highway 40. The Upper Poulton Canal flows south and provides irrigation water to farms adjacent to the Green River. The canal ends near the Green River, 1.5 mi southwest of marsh 4720. Selenium concentrations in water from the canal near marsh 4720 have ranged from 32 to $40 \mu \mathrm{g} / \mathrm{L}$. 


\title{
Biological Observations and Contamination in Biota
}

\author{
Nesting Observations at Winter Storage Pond
}

Nesting studies of waterbirds near the Winter Storage Pond started in 1988 and were completed in 1989. The study consisted of searches for occupied nests and observation of bird use of nests. Searches included the area immediately adjacent to the Winter Storage Pond but did not include the nearby sewage lagoons. A total of 4 nests were located and monitored in 1988, and 26 in 1989, not including blackbird nests; these were 13 duck, 1 Canada goose, 2 American avocet (Recurvirostra americana), 4 American coot, 2 black-necked stilt, and 8 eared grebe (Podiceps caspicus) nests. The nesting success of waterbirds monitored at Winter Storage Pond is shown in table 17. Predation was attributed to the loss of 14 nests (47 percent). Of the remaining nests, 3 (10 percent) were believed abandoned, 10 (33 percent) were believed successful in hatching at least 1 egg, and 3 (10 percent) failed to hatch eggs, even though females were attentive and observed to be incubating.

Dead embryos were identified in at least 1 egg from 11 of 27 nests that had not been abandoned. Three additional nests had embryos that were dead when examined, but it was uncertain if the dead embryos were a result of either handling following collection or embryonic health impairment. One cinnamon teal embryo had missing and truncated toes.

Table 17. Nesting success of waterbirds at the Winter Storage Pond, 1988-89

[Percent success: percentage of monitored nests known to hatch at least one egg; -, not applicable]

\begin{tabular}{lcc}
\hline \multicolumn{1}{c}{ Species } & $\begin{array}{c}\text { Monitored } \\
\text { nests }\end{array}$ & $\begin{array}{c}\text { Percent } \\
\text { success }\end{array}$ \\
\hline American avocet & 2 & 50 \\
American coot & 4 & 25 \\
Black-necked stilt & 2 & 0 \\
Canada goose & 1 & 0 \\
Eared grebe & 8 & 0 \\
Gadwall & 10 & 70 \\
Scaup & 1 & 0 \\
Cinnamon teal $\quad 2$ & 50 \\
$\quad$ Total & 30 & - \\
\multicolumn{1}{c}{ Success for all nests combined } & - & 33 \\
\hline
\end{tabular}

\section{Observations of Waterbird Use}

Waterbird use of the Winter Storage Pond and adjacent Vernal sewage lagoons was documented at approximate 1 to 2 week intervals in 1988-89. Counts at the Winter Storage Pond and Vernal sewage lagoons were combined in this analysis. The species observed are listed in table 18.

Large numbers of ducks and American coots were observed in the spring. Median counts of ducks during the summer exceeded 200 birds. These represent minimum estimates of use. Parts of the reservoir and the lagoons were not included in the count. Most counts were made from the west side of the reservoir to avoid human intrusion, which would disturb the birds and cause them to redistribute. Similarly, parts of the lagoons could not be observed without disturbing the birds. Substantial bird use of the adjacent Vernal sewage lagoons was observed at times and likely was related to some of the variability in the counts at the Winter Storage Pond. 
Table 18. List of species observed during waterbird counts at the Winter Storage Pond near Ashley Creek, Leota Bottom, and at four pond units in Pariette Wetlands, 1988-89

\begin{tabular}{|c|c|c|c|c|c|c|}
\hline \multirow{3}{*}{$\begin{array}{c}\text { SPECIES } \\
\text { Common name }\end{array}$} & \multicolumn{6}{|c|}{ OBSERVATION SITES } \\
\hline & \multirow{2}{*}{$\begin{array}{l}\text { Winter } \\
\text { Storage } \\
\text { Pond }\end{array}$} & \multirow{2}{*}{$\begin{array}{l}\text { Leota } \\
\text { Bottom }\end{array}$} & \multicolumn{4}{|c|}{ Pariette Wetlands } \\
\hline & & & Unit 1 & Unit 2 & Unit 3 & Unit 4 \\
\hline Great blue heron & $\mathbf{x}$ & $\mathbf{X}$ & $\mathbf{x}$ & $\mathbf{X}$ & $\mathbf{x}$ & $\mathbf{X}$ \\
\hline Black-crowned night heron & & & $\mathrm{x}$ & $\mathbf{X}$ & & \\
\hline White-faced ibis & $\mathbf{X}$ & $\mathrm{X}$ & $\mathrm{X}$ & $\mathrm{X}$ & $\mathbf{X}$ & \\
\hline Snowy egret & & $\mathbf{x}$ & $\mathbf{X}$ & $\mathrm{X}$ & $\mathbf{x}$ & \\
\hline Great egret & & & & $\mathrm{X}$ & & \\
\hline Cattle egret & & & & $\mathrm{X}$ & & \\
\hline Double-crested cormorant & & $\mathbf{X}$ & $\mathrm{X}$ & $\mathrm{x}$ & $\mathrm{X}$ & \\
\hline American white pelican & & & $\mathbf{X}$ & $\mathbf{X}$ & & \\
\hline Franklin's gull & $\mathrm{X}$ & & & $\mathrm{X}$ & & \\
\hline California gull & $\mathbf{X}$ & & & & & \\
\hline Ring-billed gull & & & & $\mathbf{x}$ & & \\
\hline Canada goose & $\mathbf{x}$ & $\mathbf{X}$ & $\mathrm{X}$ & $\mathrm{X}$ & $\mathbf{x}$ & $\mathbf{X}$ \\
\hline Mallard & $\mathbf{X}$ & $\mathbf{X}$ & & $\mathrm{X}$ & $\mathbf{X}$ & $\mathrm{X}$ \\
\hline Northern pintail & $\mathbf{X}$ & $\mathbf{X}$ & $\mathrm{X}$ & $\mathrm{X}$ & $\mathbf{x}$ & $\mathbf{X}$ \\
\hline Gadwall & $\mathrm{X}$ & $\mathrm{X}$ & $\mathbf{X}$ & $\mathbf{X}$ & $\mathrm{X}$ & $\mathbf{X}$ \\
\hline American wigeon & $\mathbf{x}$ & $\mathbf{X}$ & & $\mathrm{X}$ & $\mathrm{X}$ & \\
\hline Northern shoveler & $\mathrm{X}$ & $\mathbf{X}$ & & $\mathbf{X}$ & $\mathbf{X}$ & $\mathbf{X}$ \\
\hline Blue-winged teal & $\mathrm{X}$ & $\mathbf{X}$ & $\mathrm{X}$ & & $\mathrm{X}$ & $\mathrm{X}$ \\
\hline Cinnamon teal & $\mathbf{X}$ & $\mathbf{X}$ & $\mathbf{X}$ & $\mathbf{X}$ & $\mathrm{X}$ & $\mathrm{X}$ \\
\hline Green-winged teal & $\mathrm{X}$ & $\mathrm{X}$ & $\mathrm{X}$ & & $\mathrm{X}$ & $\mathrm{X}$ \\
\hline Redhead & $\mathrm{X}$ & $\mathbf{X}$ & $\mathrm{X}$ & $\mathbf{x}$ & $\mathrm{X}$ & $\mathrm{X}$ \\
\hline Scaup & $\mathbf{X}$ & $\mathbf{X}$ & $\mathrm{X}$ & $\mathbf{X}$ & $\mathbf{X}$ & \\
\hline Bufflehead & $\mathrm{X}$ & $\mathrm{X}$ & & $\mathbf{X}$ & & \\
\hline Common merganser & $\mathrm{X}$ & $\mathbf{x}$ & & & & \\
\hline Red-breasted merganser & $\mathbf{X}$ & $\mathbf{X}$ & & & & \\
\hline Ruddy duck & $\mathrm{X}$ & $\mathrm{X}$ & $\mathrm{X}$ & $\mathbf{X}$ & $\mathrm{X}$ & \\
\hline Canvasback & $\mathbf{X}$ & & & & & \\
\hline Ring-necked duck & $\mathbf{X}$ & & $\mathbf{x}$ & & & \\
\hline American coot & $\mathrm{X}$ & $\mathrm{X}$ & $\mathrm{X}$ & $\mathrm{X}$ & $\mathbf{X}$ & $\mathbf{X}$ \\
\hline Pied-billed grebe & $\mathbf{X}$ & $\mathrm{X}$ & $\mathbf{X}$ & $\mathbf{X}$ & $\mathrm{X}$ & $\mathrm{X}$ \\
\hline Eared grebe & $\mathrm{X}$ & $\mathbf{X}$ & $\mathrm{X}$ & & & \\
\hline Western grebe & $\mathrm{X}$ & $\mathbf{x}$ & $\mathrm{X}$ & $\mathbf{x}$ & & \\
\hline Long-billed curlew & $\mathrm{X}$ & & & & & \\
\hline Black-necked stilt & $\mathrm{X}$ & & $\mathbf{x}$ & $\mathrm{x}$ & $\mathbf{X}$ & $\mathrm{X}$ \\
\hline American avocet & $\mathrm{X}$ & $\mathbf{X}$ & $\mathrm{X}$ & $\mathrm{X}$ & $\mathbf{X}$ & $\mathrm{X}$ \\
\hline Willet & $\mathrm{X}$ & & & & & \\
\hline Killdeer & $\mathbf{x}$ & $\mathbf{X}$ & $\mathbf{X}$ & $\mathrm{x}$ & & $\mathrm{x}$ \\
\hline Long-billed dowitcher & $\mathrm{X}$ & & & $\mathrm{X}$ & & \\
\hline Wilson's phalarope & $\mathrm{X}$ & $\mathrm{X}$ & & $\mathrm{X}$ & $\mathrm{X}$ & $\mathrm{X}$ \\
\hline Black-bellied plover & $\mathrm{X}$ & & & & & \\
\hline Forster's tern & & $\mathrm{x}$ & $\mathbf{X}$ & $\mathrm{X}$ & $\mathrm{X}$ & \\
\hline Black tern & & $\mathrm{X}$ & & $\mathbf{X}$ & & \\
\hline
\end{tabular}


Table 18. List of species observed during waterbird counts at the Winter Storage Pond near Ashley Creek, Leota Bottom, and at four pond units in Pariette Wetlands, 1988-89-Continued

\begin{tabular}{|c|c|c|c|c|c|c|}
\hline \multirow{3}{*}{$\begin{array}{c}\text { SPECIES } \\
\text { Common name }\end{array}$} & \multicolumn{6}{|c|}{ OBSERVATION SITES } \\
\hline & \multirow{2}{*}{$\begin{array}{c}\text { Winter } \\
\text { Storage } \\
\text { Pond }\end{array}$} & \multirow{2}{*}{$\begin{array}{l}\text { Leota } \\
\text { Bottom }\end{array}$} & \multicolumn{4}{|c|}{ Pariette Wetlands } \\
\hline & & & Unit 1 & Unit 2 & Unit 3 & Unit 4 \\
\hline Bank swallow & & & & $\mathrm{X}$ & $\mathrm{x}$ & \\
\hline Barn swallow & $\mathrm{x}$ & & $\mathrm{x}$ & $\mathrm{X}$ & $\mathrm{X}$ & \\
\hline Tree swallow & $\mathrm{x}$ & & & $\mathrm{X}$ & $\mathrm{X}$ & \\
\hline Yellow-headed blackbird & $\mathrm{x}$ & $\mathbf{X}$ & $\mathbf{X}$ & $\mathrm{X}$ & $\mathrm{X}$ & \\
\hline Red-winged blackbird & & & & $\mathrm{x}$ & & \\
\hline Northern harrier & & & $\mathrm{X}$ & & & \\
\hline Bald eagle & & $\mathrm{x}$ & & & & \\
\hline Golden eagle & & $\mathrm{X}$ & & & & \\
\hline Peregrine falcon & & & & & $\mathrm{X}$ & \\
\hline
\end{tabular}

Duck counts were particularly large during migration, in both the spring and fall. Total counts ranged from 58 ducks in August to 1,844 ducks in March and consisted of mostly gadwall, northern shoveler (Anas spatulata), and diving ducks. No counts were made during October; however, a collection of waterfowl during November 1988 was done when more than 800 ducks were using two lagoons near the Winter Storage Pond. The pattern of American coot use was similar to duck use, except for less use during the fall.

Counts of waterbird broods on the Winter Storage Pond were conducted in 1988 and 1989 incidental to systematic counts of waterbird uses. One brood of gadwall and one of Canada goose were observed during the two years in spite of the fact that eggs in several of the duck nests were known to have hatched.

\section{Residue in Biological Tissue}

A total of 29 randomly collected individual eggs or composite samples of randomly collected eggs and 4 non-randomly collected eggs were analyzed (table 19). Geometric mean selenium concentrations by bird species in the randomly collected eggs (where more than a single sample of a bird species was collected) ranged from $7.3 \mu \mathrm{g} / \mathrm{g}$ dry weight to $60.6 \mu \mathrm{g} / \mathrm{g}$. Of $33 \mathrm{eggs}$ analyzed (Peltz and Waddell, 1991, p. 86), the smallest selenium concentration was in a gadwall egg, $4.1 \mu \mathrm{g} / \mathrm{g}$. The largest concentration was in an eared grebe egg, $71 \mu \mathrm{g} / \mathrm{g}$. Deformities (missing or truncated toes) were observed in a cinnamon teal embryo that had $42.7 \mu \mathrm{g} / \mathrm{g}$ selenium.

Geometric mean selenium concentrations in non-random eggs of cinnamon teal were similar to random eggs (table 19). For gadwall, non-random eggs had a numerically but not statistically larger geometric mean than randomly collected eggs, but both non-random eggs were from the same nest and had smaller concentrations than the randomly collected eggs from that nest.

Tissue from two American coots and three ducks were collected during the fall to simulate hunter take. These birds contained large selenium concentrations in their liver and breast muscle. The geometric mean selenium concentration in muscle tissue of the coots was $16.2 \mu \mathrm{g} / \mathrm{g}$ and ranged from 9.63 to $27.2 \mu \mathrm{g} / \mathrm{g}$. Selenium concentration in the three ducks ranged from 13.3 to $20.3 \mu \mathrm{g} / \mathrm{g}$ (Peltz and Waddell, 1991, p. 86). Humans consuming these birds could easily exceed the recommended daily limit of $200 \mu \mathrm{g}$ of selenium for adults (National Academy of Sciences, 1980). Based on selenium concentration in the five birds collected, $1.6 \mathrm{oz}$ of fresh muscle tissue would provide the daily recommended limit. 
Table 19. Geometric mean selenium concentrations in biological samples from Winter Storage Pond and in fish samples collected nationwide by the National Contaminant Biomonitoring Program

[All eggs are random except those identified by NR, non-random; LV, liver; MS, muscle; mm, millimeter; g, gram; egg weight, contents of egg; $\mu \mathrm{g} / \mathrm{g}$, micrograms per gram (dry weight); - , not specified. NCBP, National

Contaminant Biomonitoring Program, from Schmitt and Brumbaugh, 1990 (1984 geometric mean concentration, 85th percentile, converted to dry weight using 75-percent moisture). Mean length, weight, and moisture content are arithmetic means]

\begin{tabular}{|c|c|c|c|c|c|c|}
\hline Species & $\underset{\text { size }}{\text { Sample }}$ & $\begin{array}{c}\text { Sample } \\
\text { type }\end{array}$ & $\begin{array}{c}\text { Mean } \\
\text { length } \\
(\mathrm{mm})\end{array}$ & $\begin{array}{c}\text { Mean } \\
\text { weight } \\
\text { (g) }\end{array}$ & $\begin{array}{c}\text { Mean } \\
\text { moisture } \\
\text { content } \\
\text { (percent) }\end{array}$ & $\begin{array}{c}\text { Geometric } \\
\text { mean selenium } \\
\text { concentration } \\
(\mu \mathrm{g} / \mathrm{g})\end{array}$ \\
\hline
\end{tabular}

\begin{tabular}{|c|c|c|c|c|c|c|}
\hline \multicolumn{7}{|c|}{ Bird eggs } \\
\hline American avocet & 2 & Individual & - & 27 & 73.3 & 14.1 \\
\hline American coot & 4 & Individual & 49 & 26 & 75.8 & 30.3 \\
\hline Black-necked stilt & 2 & Individual & - & 18 & 73.5 & 33.0 \\
\hline Canada goose & 1 & Individual & 86 & 117 & 70.6 & 4.52 \\
\hline Cinnamon teal & 2 & Individual & 47 & 23 & 64.4 & 35.6 \\
\hline Cinnamon teal (NR) & 2 & Individual & 46 & 20 & 66.1 & 38.9 \\
\hline Eared grebe & 5 & Individual & - & 18 & 78.1 & 60.6 \\
\hline Gadwall & 10 & Individual & 49 & 36 & 68.2 & 7.3 \\
\hline Gadwall (NR) & 2 & Individual & 51 & 32 & 61.9 & 13.3 \\
\hline Northern harrier & 1 & Individual & 48 & 28 & 82.9 & 5.2 \\
\hline Scaup & 1 & Individual & - & 39 & 65.9 & 29.5 \\
\hline Yellow-headed blackbird & 1 & Composite & - & 4 & 83.4 & 12 \\
\hline \multicolumn{7}{|c|}{ Bird tissue - November } \\
\hline American coot (LV) & 2 & Individual & - & - & 74.3 & 37.9 \\
\hline American coot (MS) & 2 & Individual & - & - & 74.2 & 16.2 \\
\hline Goldeneye (LV) & 1 & Individual & - & - & 73.3 & 50.3 \\
\hline Goldeneye (MS) & 1 & Individual & - & - & 71.8 & 20.3 \\
\hline Ruddy duck (LV) & 1 & Individual & - & - & 71.9 & 43.3 \\
\hline Ruddy duck (MS) & 1 & Individual & - & - & 71.0 & 16.7 \\
\hline Scaup (LV) & 1 & Individual & - & - & 71.0 & 30.8 \\
\hline Scaup (MS) & 1 & Individual & - & - & 71.5 & 13.3 \\
\hline \multicolumn{7}{|c|}{ Fish - whole body } \\
\hline Black bullhead & 1 & Individual & 362 & 897 & 81.8 & 17.6 \\
\hline Fish, NCBP nationwide & - & Composite & - & - & 75.0 & 2.9 \\
\hline \multicolumn{7}{|c|}{ Plants } \\
\hline Chara & 4 & Composite & - & - & 80.6 & 6.9 \\
\hline Water milfoil & 3 & Composite & - & - & 88.2 & 4.4 \\
\hline Potamogeton & 5 & Composite & - & - & 88.2 & 8.5 \\
\hline Cattail & 1 & Composite & - & - & 81.6 & 8.4 \\
\hline \multicolumn{7}{|c|}{ Invertebrates } \\
\hline Invertebrates, mixed & 3 & Composite & - & - & 89.0 & 40.1 \\
\hline
\end{tabular}


Selenium concentrations in the invertebrate samples ranged from 36.7 to $42 \mu \mathrm{g} / \mathrm{g}$ (Peltz and Waddell, 1991, p. 89). The samples of mixed invertebrates had a geometric mean selenium concentration of $40.1 \mu \mathrm{g} / \mathrm{g}$ (table 19).

The only fish caught during gill netting at the Winter Storage Pond in the spring and summer of 1989 was a single black bullhead. It had a whole-body selenium concentration of $17.6 \mu \mathrm{g} / \mathrm{g}$ (table 19).

A small number of biological samples, primarily fish, plants, and crustaceans, were collected in Ashley Creek. Sampling was conducted at four sites: within 1,300 ft east of 500 North Street in Vernal; near the confluence of the Burns Bench Canal; within $300 \mathrm{ft}$ of U.S. Highway 40; and within $300 \mathrm{ft}$ of the county road west of Stewart Lake WMA.

Selenium concentrations in fish from four sites on Ashley Creek ranged from $1.6 \mu \mathrm{g} / \mathrm{g}$ to 122 $\mu \mathrm{g} / \mathrm{g}$ (dry weight) (Peltz and Waddell, 1991, p. 82), with a geometric mean of $32.7 \mu \mathrm{g} / \mathrm{g}$ when data for all sites were combined (table 20). For all species of fish combined, the selenium concentration was significantly larger (ALS 0.04) in fish from all sites downstream from the city of Vernal than at the site in Vernal. Selenium concentrations were small in redside shiners (Richardsonius balteatus) and small suckers (Catastomus spp.) collected from Ashley Creek at 500 North Street. Selenium concentrations were large in fish at all the remaining sites. The only duplicate sample of fish at a site was for white sucker (Catastomus commersoni) collected at the confluence of the Burns Bench Canal with a mean selenium concentration of $38.8 \mu \mathrm{g} / \mathrm{g}$. The largest selenium concentrations found in whole-body fish at any site during this study was a sample of fathead minnow (Pimephales promelas) containing $122 \mu \mathrm{g} / \mathrm{g}$.

Two samples of crayfish collected at the U.S. Highway 40 and county road sites had a mean selenium concentration of $43.0 \mu \mathrm{g} / \mathrm{g}$. This species represents a primary scavenger in the stream (table 20).

Two samples of plants were collected. Potamogeton collected upstream of the seleniumcontaminated area of Ashley Creek at 500 North Street had a small selenium concentration, $1.6 \mu \mathrm{g} / \mathrm{g}$. Chara collected downstream from the city of Vernal at the county road near Jensen had a selenium concentration of $13.3 \mu \mathrm{g} / \mathrm{g}$.

Plant samples collected at several areas at the Winter Storage Pond had selenium concentrations ranging from 2.2 to $30.4 \mu \mathrm{g} / \mathrm{g}$. Cattails had a concentration of $8.4 \mu \mathrm{g} / \mathrm{g}$ and potamogeton had a geometric mean concentration of $8.5 \mu \mathrm{g} / \mathrm{g}$ (table 19). All samples of rooted non-emergent aquatic plants (excluding chara), when analyzed together, had a geometric mean selenium concentration of 6.6 $\mu \mathrm{g} / \mathrm{g}$. At one site, potamogeton had selenium concentrations ranging from $3.9 \mu \mathrm{g} / \mathrm{g}$ in the summer to 16 and $30.4 \mu \mathrm{g} / \mathrm{g}$ of selenium in two samples collected in the fall and spring, respectively (Peltz and Waddell, 1991, p. 89). Chara had a geometric mean selenium concentration of $6.9 \mu \mathrm{g} / \mathrm{g}$. Boron concentrations ranged from 14 to $2,940 \mu \mathrm{g} / \mathrm{g}$. Boron concentrations in all 5 samples of potamogeton exceeded $1,000 \mu \mathrm{g} / \mathrm{g}$.

\section{HYDROLOGY AND CONTAMINANTS IN BIOTA IN THE AREA OF PELICAN LAKE AND OURAY NATIONAL WILDLIFE REFUGE}

\section{Hydrology and Water Quality}

Mean annual precipitation of about 9 in. at Ouray NWR provides only small quantities of water for wildlife, agriculture, or ground-water recharge. The source of the most water used in the area is Pelican Lake, a natural lake that receives water from the south slope of the Uinta Mountains. Water is released from Pelican Lake through canals to provide irrigation for local farms and Ouray NWR. 
Table 20. Geometric mean selenium concentrations in samples of whole-body minnows and other small fish, plants (chara and potamogeton), and crayfish collected from Ashley Creek and in fish samples collected nationwide by the National Contaminant Biomonitoring Program

[ $\mu \mathrm{g} / \mathrm{g}$, micrograms per gram (dry weight); - , not specified, NCBP, National Contaminant Biomonitoring Program, from Schmitt and Brumbaugh, 1990 (1984 geometric mean concentration, 85th percentile, converted to dry weight using 75 percent moisture); mean moisture content is an arithmetic mean]

\begin{tabular}{|c|c|c|c|c|}
\hline Sampling site & $\begin{array}{c}\text { Sample } \\
\text { size }\end{array}$ & $\begin{array}{c}\text { Sample } \\
\text { type }\end{array}$ & $\begin{array}{l}\text { Mean } \\
\text { moisture } \\
\text { content } \\
\text { (percent) }\end{array}$ & $\begin{array}{c}\text { Geometric } \\
\text { mean selenium } \\
\text { concentration } \\
(\mu \mathrm{g} / \mathrm{g})\end{array}$ \\
\hline \multicolumn{5}{|c|}{ Fish } \\
\hline 6550 East, Naples & 5 & Composite, Individual & 77.8 & 41.0 \\
\hline U.S. Highway 40, Jensen & 2 & Composite & 77.4 & 77.3 \\
\hline County road at Jensen & 4 & Composite, Individual & 76.4 & 60.4 \\
\hline Above sites combined & 11 & Composite, Individual & 77.2 & 52.9 \\
\hline North Vernal Avenue & 2 & Composite & 75.8 & 2.3 \\
\hline All fish all locations & 13 & Composite, Individual & 77.0 & 32.7 \\
\hline Fish, NCBP nationwide & - & Composite & 75.0 & 2.9 \\
\hline \multicolumn{5}{|c|}{ Chara } \\
\hline County road at Jensen & 1 & Composite & 85.7 & 13.3 \\
\hline \multicolumn{5}{|c|}{ Potamogeton } \\
\hline North Vernal Avenue & 1 & Composite & 87.7 & 1.6 \\
\hline \multicolumn{5}{|c|}{ Crayfish } \\
\hline North Vernal Avenue & 2 & Composite & 77.3 & 43.0 \\
\hline
\end{tabular}

Water is diverted from the Lake Canal by the Ouray Park Irrigation Company and is used in the agricultural fields in the eastern part of Sheppard Bottom. Water from Lake Canal also may enter the northwest corner of Ouray Refuge and flow into the North Roadside Pond. Ground-water seepage also provides water to the North Roadside Pond. During drought, water delivered through the Lake Canal is dependent on the water available in Pelican Lake. From 1986 to 1989 an annual average of 541 acre$\mathrm{ft}$ was delivered to the agricultural fields in the refuge from the Lake Canal (Gary Montoya, Ouray NWR, oral commun., 1990).

Recharge to the unconsolidated basin-fill (alluvial) aquifer system is primarily by seepage from canals and streams. An annual conveyance loss from the canal delivering water to Ouray NWR was estimated to be 700 to 1,000 acre-ft or about $4 \mathrm{ft}^{3} / \mathrm{s}$ per day during the irrigation season (Richard Sjostrom, Ouray NWR, oral commun., 1989). Most of the recharge to the unconsolidated basin fill is to the shallow ground-water zone. 


\section{Ground-Water Flow and Water Levels}

Ground water is discharged in the areas of the Roadside Ponds and Sheppard Bottom by seeps and subsurface flow to ponds. Ground water not discharged in the refuge likely flows to the Green River. The quantity of seepage entering the North Roadside Pond was estimated to be 0.6 acre-ft per day on the basis of an average discharge of $0.32 \mathrm{ft}^{3} / \mathrm{s}$ from the pond during periods between September and April when there was no surface-water flow to the pond. Evaporation was minimal, and the water level in the pond was stable.

Movement of the shallow ground water in the area of the North Roadside draw is to the south and east toward Sheppard Bottom and the Green River. Contours of the water table of the shallow aquifer for April 1989 are shown in figure 36. Data from wells in the North Roadside Pond and Sheppard Bottom area and two locations on the Green River were used to contour the water-level elevations relative to a sea level datum. The elevations of the Green River were adjusted from the river stage as measured at USGS station 09261000 near Jensen, Utah. The ground-water flow is perpendicular to the contour lines and moves downgradient to the Green River.

There was little variation in water-level contours in the area during 1989 . Water levels in shallow wells were generally highest in April owing to a small quantity of local recharge and reduced evapotranspiration. Water levels declined during the summer. The higher water levels in at least one well in the Sheppard Bottom area (Ag Field well) during spring may be attributed to the increased stage and discharge in the Green River flowing $0.7 \mathrm{mi}$ east of the well (fig. 37).In addition, water pumped from the Green River during spring to fill ponds in the Sheppard Bottom area contributes to local recharge. Water levels in this well declined as the discharge and stage of the Green River declined through the summer.

Water levels in the S3 well near the Green River declined from March to July and remained near 4,650 ft through September (fig. 38). At about this elevation, shallow ground-water levels are controlled by the elevation of the Green River. Well S3 was drilled to a depth of $38 \mathrm{ft}$ with the bottom $20 \mathrm{ft}$ screened (screened interval 4,619.41 to 4,639.41 ft above sea level). In spring, when water levels upgradient were highest and river elevation was low, water levels in the S3 well were determined by the movement of ground water entering the Sheppard Bottom area from the north and west that then flowed downgradient to discharge into the Green River. During summer, water levels were determined by the stage of the Green River; however, the summer pattern was not evident in water levels in well $\mathrm{S5}$, which declined to 4,648.78 $\mathrm{ft}$ in September (fig. 38). The shallower well, S5, is about $0.75 \mathrm{mi}$ north of the river and was drilled to a depth of $15.5 \mathrm{ft}$ and screened from 4,642.41 to 4,647.41 ft. Owing to the distance from the Green River, this well may be hydraulically isolated from the river.

Although there were annual variations of about $2 \mathrm{ft}$ in water levels in shallow wells near the North Roadside draw, there was little between-year variation during the 1988-89 monitoring (fig. 40). Total precipitation of 7.18 in. at Ouray NWR in water-year 1988 was slightly more than the 5.01 in. received in 1989. The wells in the North Roadside draw are shallow, ranging in depth from 5 to $12 \mathrm{ft}$, and as a group indicated water levels declined slightly during 1989. Periods of precipitation, however, did not correlate with increased water levels in the shallow wells (fig. 39). Water levels in two deeper wells located within $100 \mathrm{ft}$ of well NR3 also declined more than $2 \mathrm{ft}$ during October 1988 through September 1989 (fig. 40).

The higher water levels during late April 1989 in the Evans well (fig. 41) $1.2 \mathrm{mi}$ north of the refuge and wells in the draw north of the North Roadside Ponds were due to a small quantity of recharge by winter storms and reduced evapotranspiration. Water levels in a $13 \mathrm{ft}$ deep well (Prairie Dog well) at the extreme southwestern edge of the refuge showed little change in elevation during 1989 (fig. 41). 


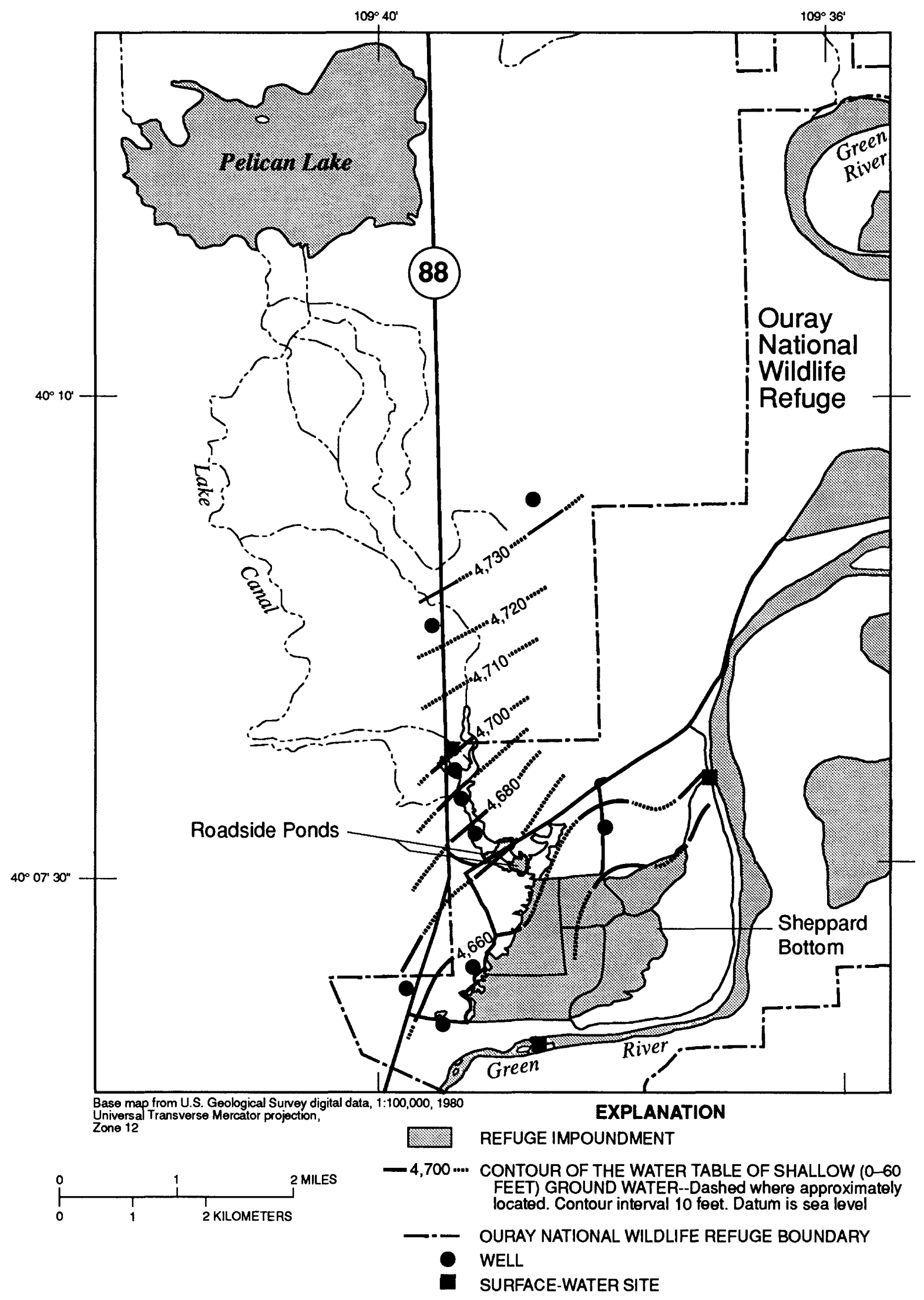

Figure 36. Contours of the water table of shallow (0-60 feet) ground water in the area of the Roadside Ponds and Sheppard Bottom at Ouray National Wildlife Refuge in April 1989. 


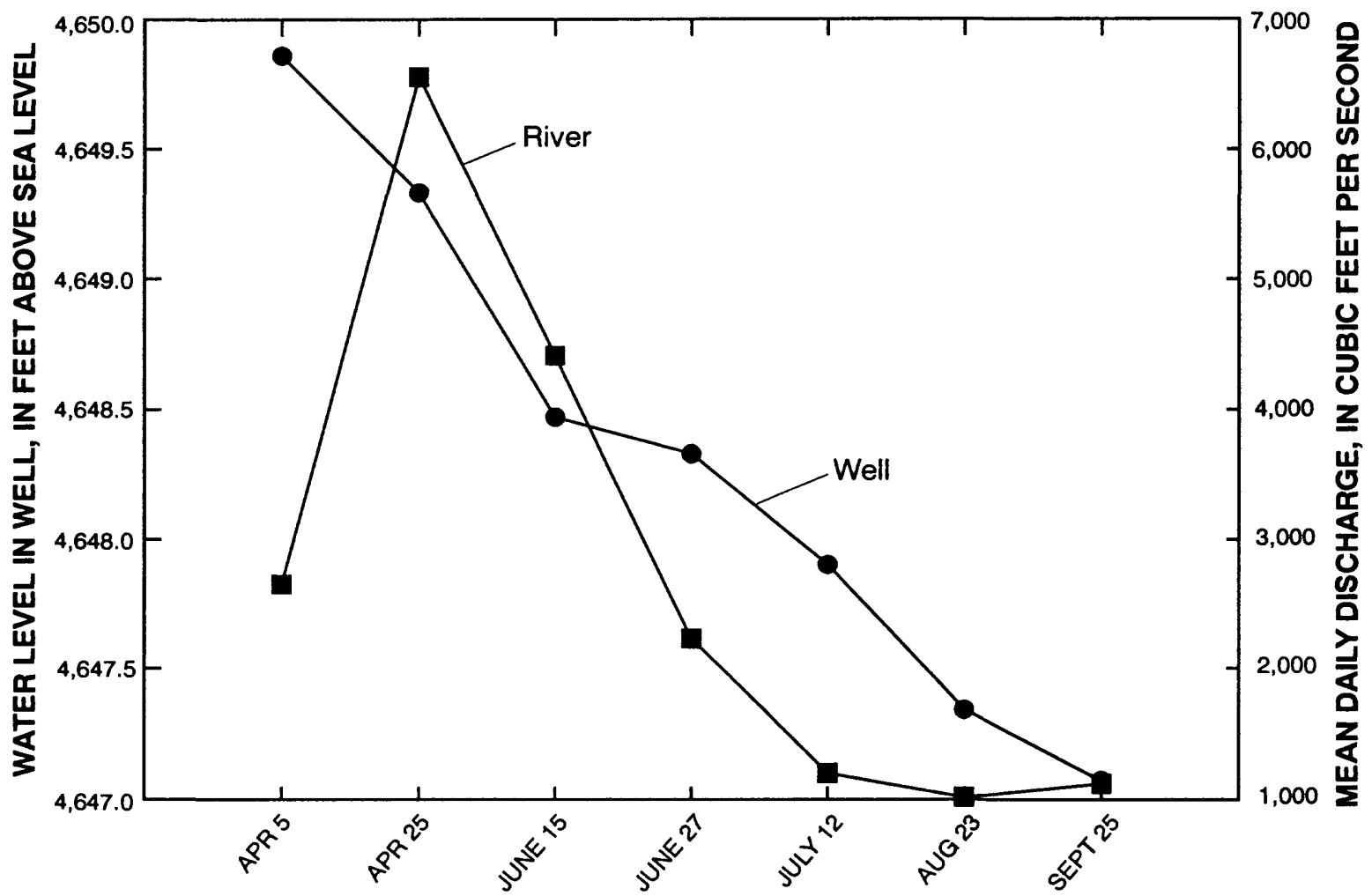

Figure 37. Changes in water level in the Ag Field well and changes in mean daily discharge of the Green River near Jensen, Utah, 1989.

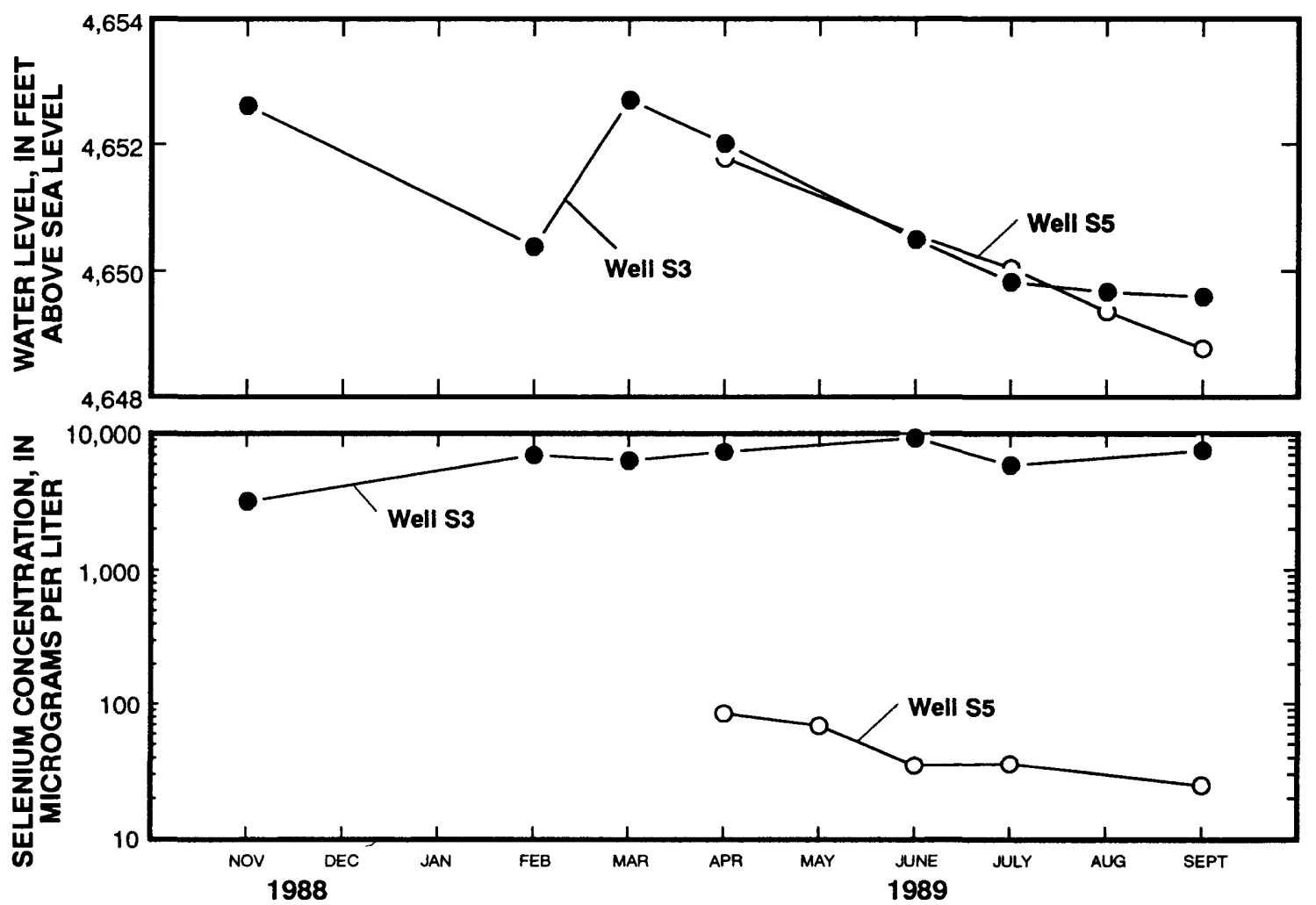

Figure 38. Selenium concentrations and water levels in the $\mathrm{S} 3$ and $\mathrm{S} 5$ wells in Sheppard Bottom at Ouray National Wildlife Refuge. 


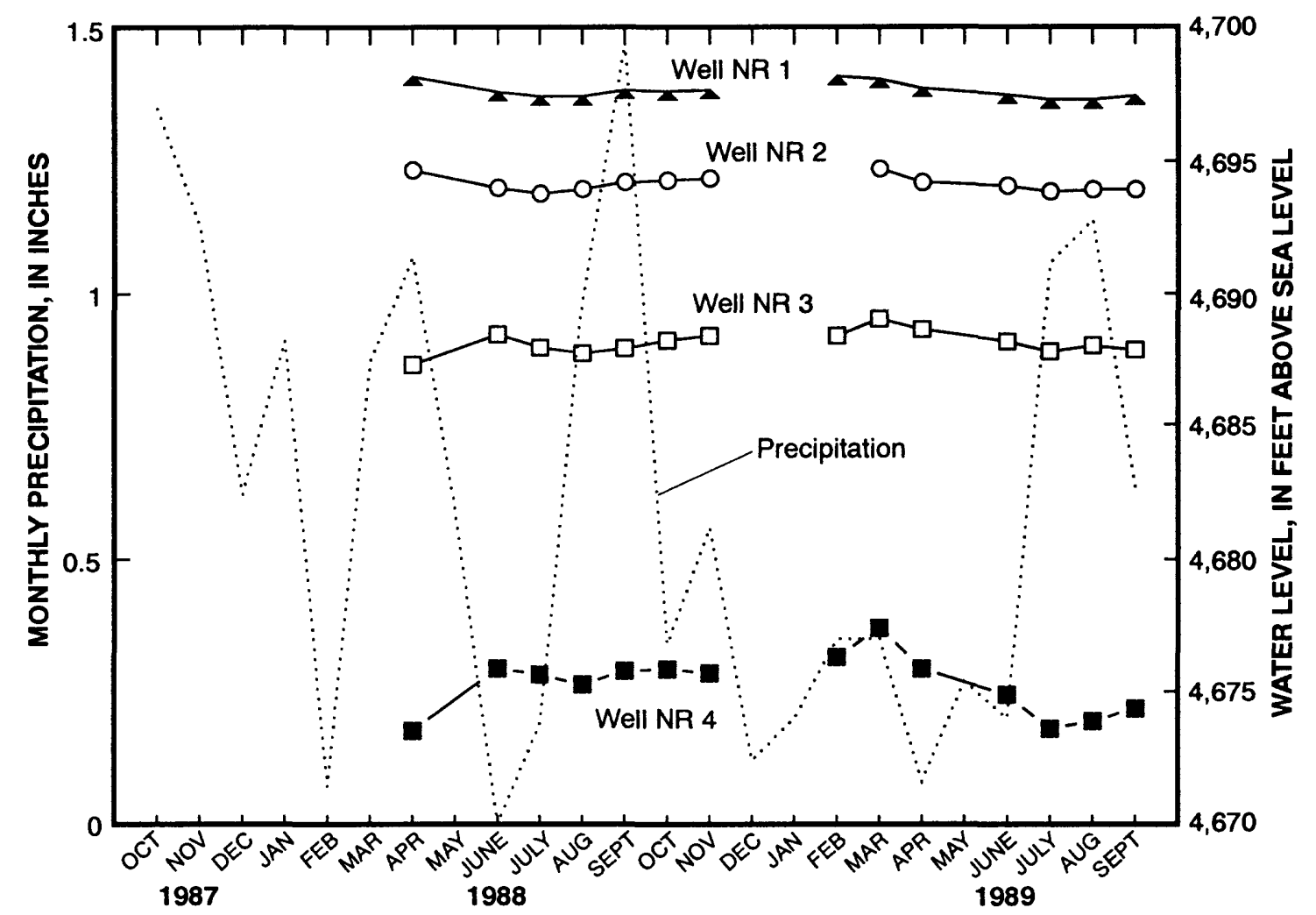

Figure 39. Total monthly precipitation at Ouray 4 NE weather station and water levels for shallow wells in the North Roadside draw at Ouray National Wildlife Refuge.
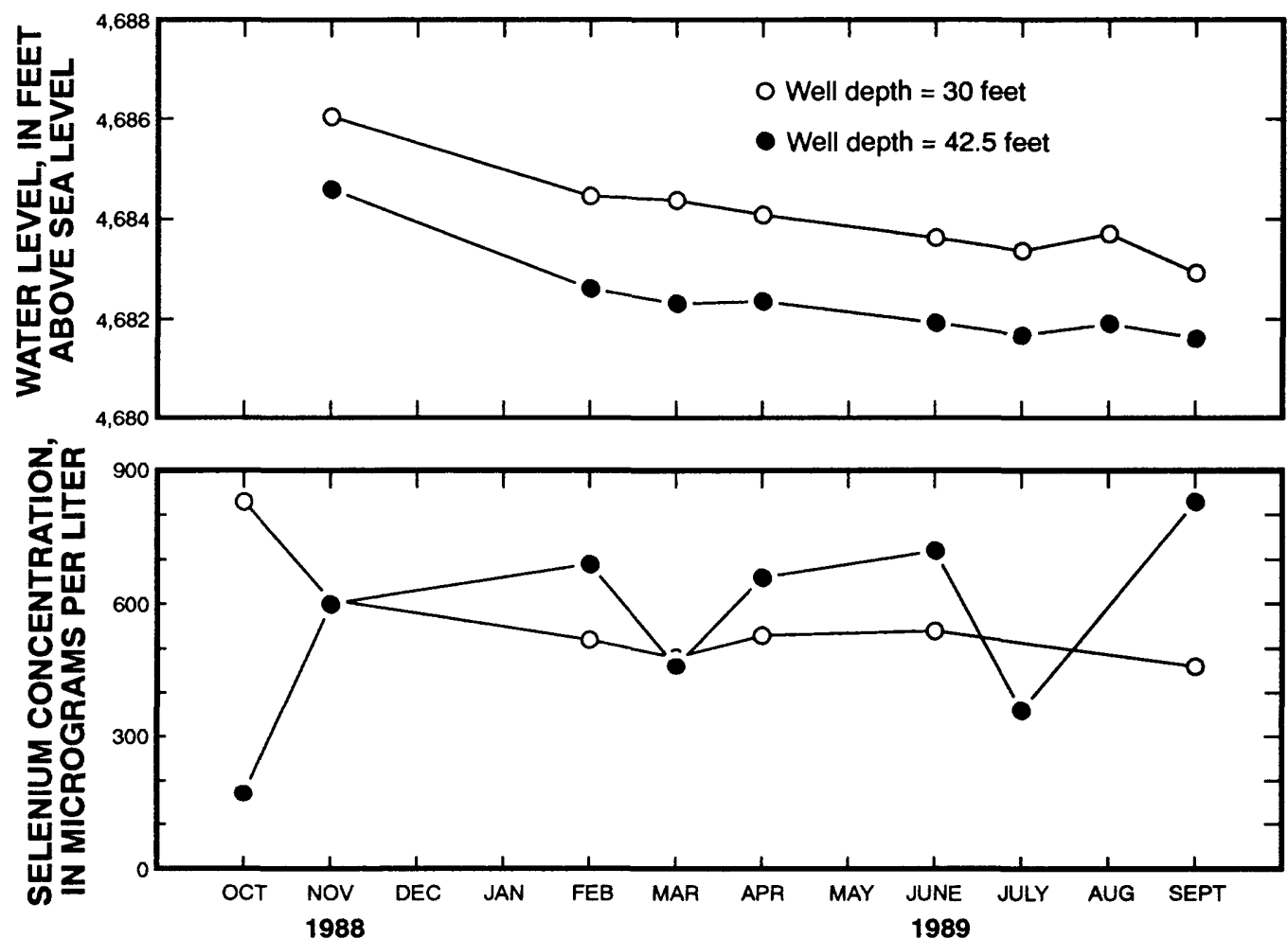

Figure 40. Selenium concentrations and water levels in two wells in the North Roadside 3 draw at Ouray National Wildlife Refuge. 


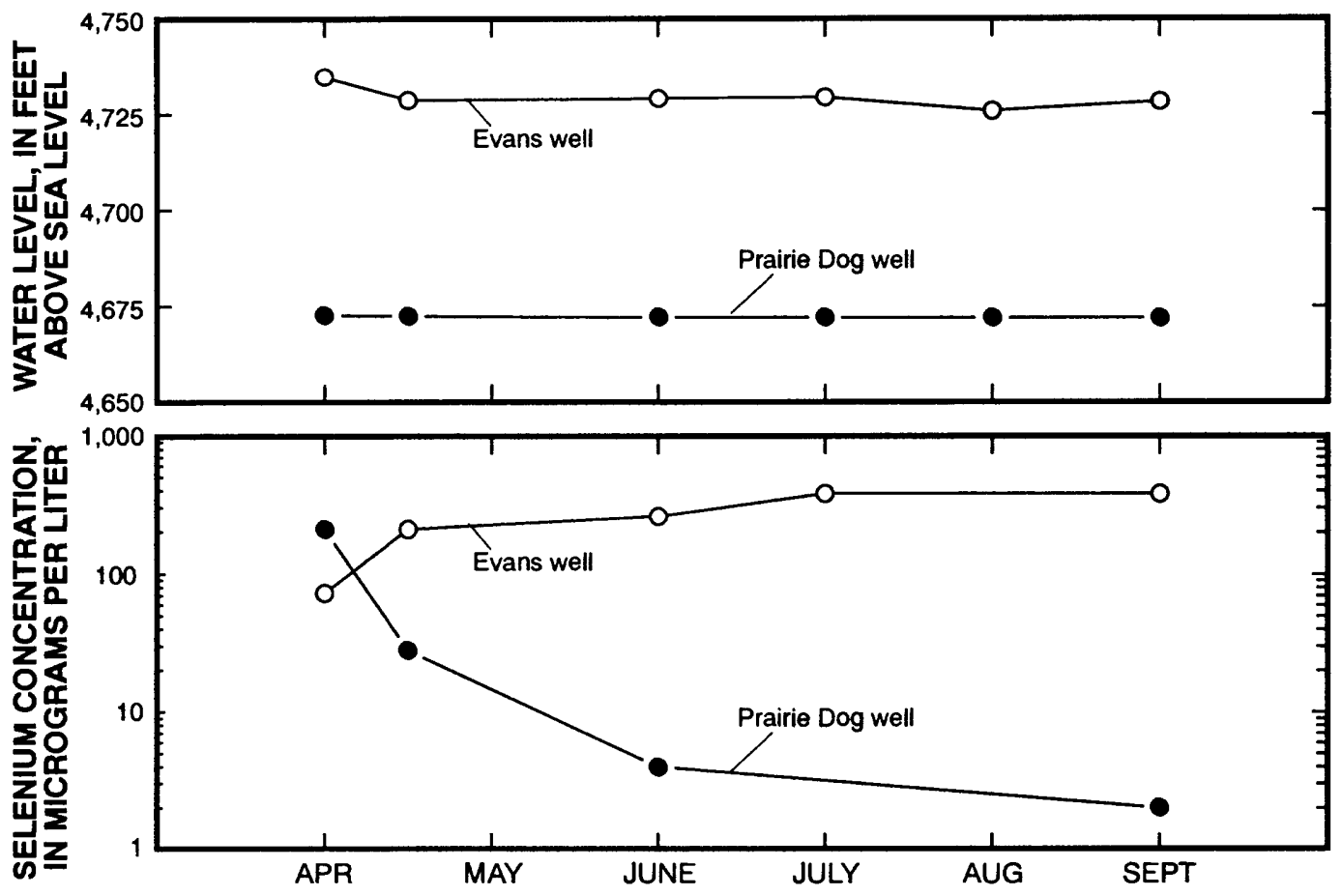

Figure 41. Selenium concentrations and water levels in the Evans and Prairie Dog wells near Ouray National Wildlife Refuge, 1989.

\section{Selenium in Ground Water}

Large variations were found in selenium concentrations in wellwater in and near Ouray NWR. Boxplots summarizing selenium concentrations in the wells in the area are shown in figure 42 . There were data values classified as "outliers" or "far outliers" in 6 of the 11 wells. For data that are normally distributed, "outliers" occur fewer than once in 100 observations and "far outliers" occur fewer than once in 300,000 observations. Ten of the eleven wells were located on the western edge of the refuge. The Ag Field well was located south of refuge headquarters near the eastern edge of Sheppard Bottom. The wells were drilled to depths ranging from 5 to $65 \mathrm{ft}$ but only 4 wells exceeded $30 \mathrm{ft}$ in depth. The median selenium concentration in 73 percent of the wells exceeded $30 \mu \mathrm{g} / \mathrm{L}$; it exceeded the aquaticwildlife standard of $5 \mu \mathrm{g} / \mathrm{L}$ in 82 percent of the wells. Selenium concentrations were typically small or less than detection levels in the Ag Field and NR4 wells. A maximum concentration of 9,300 $\mu \mathrm{g} / \mathrm{L}$ was detected in the S3 well.

While water levels in shallow wells near the North Roadside Pond showed only small annual changes, selenium concentrations in these wells had considerable variation (fig. 43). Selenium in well NR1 near the northwest corner of the refuge steadily increased from 12 to $110 \mu \mathrm{g} / \mathrm{L}$ between June 1988 and September 1989. Selenium concentrations in wells NR2 and NR3 varied somewhat in unison but with no cyclic pattern in 1988 and 1989. Generally, the largest selenium concentrations in the shallow wells were from NR3, and the average concentration was $133 \mu \mathrm{g} / \mathrm{L}$.

Two deeper wells ( 30 and $42.5 \mathrm{ft}$ ) were installed in the same draw as the NR3 well. Selenium concentrations in water from these wells (fig. 40), were considerably larger than in the shallow well (fig. 43), averaging 533 and $561 \mu \mathrm{g} / \mathrm{L}$, respectively. Selenium concentrations tended to decline in the shallow well from October 1988 to September 1989 but were variable in the deepest well, ranging from less than 200 to over $800 \mu \mathrm{g} / \mathrm{L}$. While seepage containing varying selenium concentrations enters the drainage in several reaches upstream of the North Roadside Pond, seepage in the draw where the NR3 wells are had the largest selenium concentrations. 


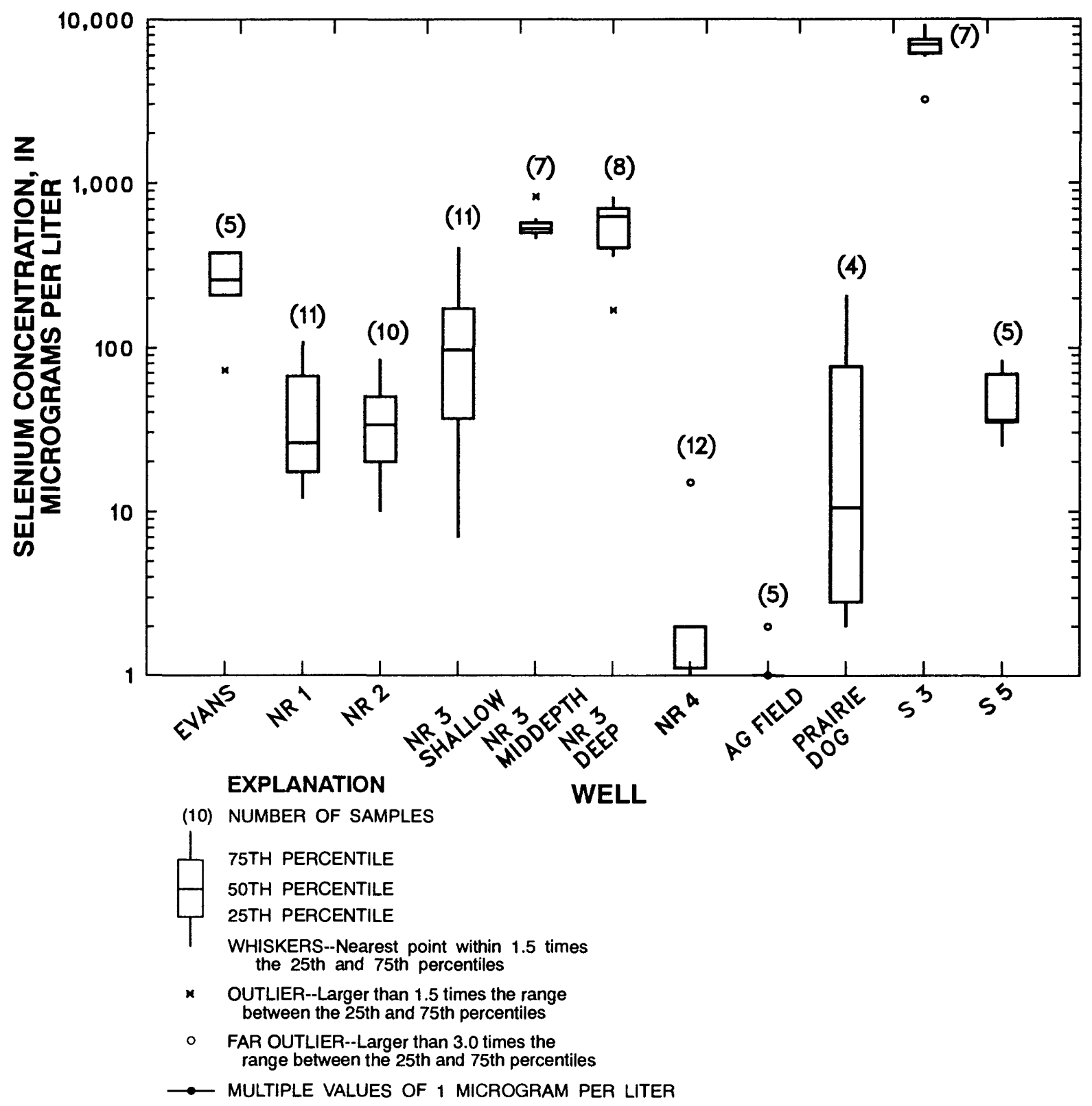

Figure 42. Selenium concentrations in water from wells in the area of Ouray National Wildlife Refuge, 1988-89.

The largest selenium concentrations measured in ground water at Ouray NWR were in the S3 well in the southwest corner of the refuge about $0.25 \mathrm{mi}$ north of the Green River. Concentrations in this well increased from 3,200 $\mu \mathrm{g} / \mathrm{L}$ in November 1988 to $9,300 \mu \mathrm{g} / \mathrm{L}$ in June 1989 and then declined slightly (fig. 38). The June decline in concentrations might have resulted from dilution by ground water recharge from the Green River that contained only small selenium concentrations. Selenium concentrations in well S5, about $0.5 \mathrm{mi}$ to the north of well S3, were smaller and declined from $85 \mu \mathrm{g} / \mathrm{L}$ in April to $13 \mu \mathrm{g} / \mathrm{L}$ in September 1989. Well S5 is adjacent to the Sheppard 5 Pond. The Sheppard 5 Pond normally fills in spring as a result of surface-water inflow from the South Roadside Pond and ground-water seepage. In 1989, selenium concentrations in the surface inflow to the Sheppard 5 Pond declined from $48 \mu \mathrm{g} / \mathrm{L}$ in April to $17 \mu \mathrm{g} / \mathrm{L}$ in June. The declining selenium concentrations in this well during summer likely represented dilution by surface water from the Sheppard 5 Pond that recharged the alluvial aquifer. 
Selenium concentrations in the Ag Field well in the eastern part of Sheppard Bottom, $0.7 \mathrm{mi}$ from the Green River, were generally less than $1 \mu \mathrm{g} / \mathrm{L}$ and never exceeded $2 \mu \mathrm{g} / \mathrm{L}$. The well is screened at elevations lower than the Green River, and water in the well may be influenced by the Green River. There was a generally positive correlation between water levels in this well and stage of the Green River (fig. 37). On April 6, 1989, the composition of major ions in water from this well was a sodium magnesium sulfate type. Water in the Green River near Jensen, $30 \mathrm{mi}$ upstream, was a sodium calcium sulfate bicarbonate type one week earlier. It is possible that on April 6, ground water in the well consisted of recharge originating upgradient to the north and west, not water from the Green River. As discharge and stage in the Green River increased from April 5 to April 25, the influence of the river on the $\mathrm{Ag}$ Field well became more pronounced.

Selenium concentrations in the Evans well, $1.2 \mathrm{mi}$ north of Ouray NWR, increased from 73 to $380 \mu \mathrm{g} / \mathrm{L}$ between April and September 1989. During the same period, selenium concentrations in the Prairie Dog well, about $0.5 \mathrm{mi}$ west of the S3 well, declined from 210 to $2 \mu \mathrm{g} / \mathrm{L}$ (fig. 41). Water levels in both wells remained relatively constant during the period. Reasons for these changes are not known.

Selenium concentrations in well water varied from large to very large in many of the wells. The source of the selenium is likely scattered deposits of seleniferous soil within the alluvial aquifer on the west side of the refuge. At the time the shallow wells were drilled in 1988-89, at least one sample of core cuttings was collected from each well and analyzed for total selenium. Typically the cuttings were collected from clay horizons near the bottom of the wells; however, samples were collected at about 5 -ft intervals from the NR3 deep well. The selenium content of all samples was less than the reporting limit of $1 \mu \mathrm{g} / \mathrm{g}$. Although the concentration appears to be very small, when

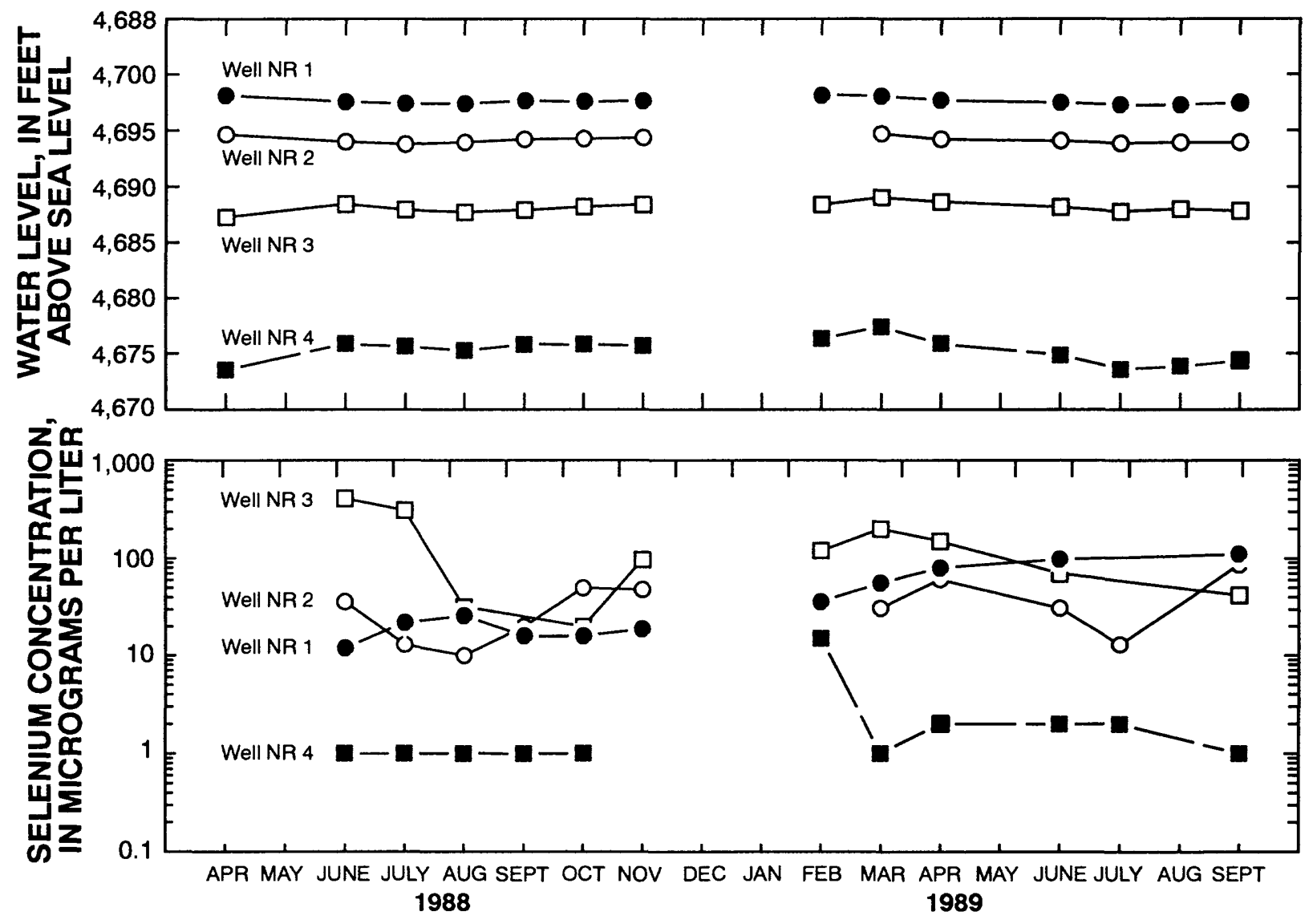

Figure 43. Selenium concentrations and water levels in shallow wells in the draw north of North Roadside Pond at Ouray National Wildlife Refuge. 
expressed in units equivalent to those used to report concentrations in water, the reporting limit is $1,000 \mu \mathrm{g} / \mathrm{kg}$. Two samples were analyzed using a more sensitive method, and the selenium concentration in both samples was $0.6 \mu \mathrm{g} / \mathrm{g}(600 \mu \mathrm{g} / \mathrm{kg})$. Part of the large selenium concentration in the NR3 deep well is due to soils in the immediate vicinity of the well.

Ground water is discharged as seepage from the hillside on the western border of Sheppard Bottom at several locations. A seep 100 yds west of the S3 well provided sufficient water to maintain a shallow pond $15 \mathrm{ft}$ in diameter throughout most of 1988-89. In August 1988, water in this pond contained a selenium concentration of $29 \mu \mathrm{g} / \mathrm{L}$. A seep nearby only flows in early spring, and the small volume of flow discharges to the S3 pond. In March 1989, water from this seep contained a selenium concentration of $73 \mu \mathrm{g} / \mathrm{L}$, a dissolved-solids concentration near $2,800 \mathrm{mg} / \mathrm{L}$, and the water was a sodium sulfate type. A small quantity of seepage entering the S5 pond from the west was sampled in June 1988 , but the selenium concentration was less than $1 \mu \mathrm{g} / \mathrm{L}$.

\section{Salinity and Boron in Ground Water}

Specific conductance of most water samples collected during the study was measured and a limited number of samples analyzed for dissolved-solids concentration. There was a positive relation with a coefficient of determination of 0.96 between specific conductance and dissolved-solids concentration in water from wells near Ouray NWR. Discussion of the dissolved-solids content of the ground water, commonly called "salinity," therefore will be based on measurements of specific conductance.

With the exception of the Evans, NR4, and Prairie Dog wells, virtually all ground-water samples exceeded a specific conductance of $4,000 \mu \mathrm{S} / \mathrm{cm}$ (fig. 44). Water from wells in small draws upgradient of the North Roadside Pond typically was salty, with median values of specific conductance of 5,000-6,000 $\mu \mathrm{S} / \mathrm{cm}$. The specific conductance of water from three wells in the Sheppard Bottom area was never less than $11,000 \mu \mathrm{S} / \mathrm{cm}$ and was as large as $37,000 \mu \mathrm{S} / \mathrm{cm}$. Generally, sodium, chloride, and sulfate were the principal ions contributing to the large conductance.

Boron concentrations, determined in six samples from wells north of the North Roadside Pond, ranged from 580 to $1,500 \mu \mathrm{g} / \mathrm{L}$. Concentrations decreased with distance downgradient from the north border of the refuge. Although the largest concentration was twice as large as the Utah water-quality standard for the protection of sensitive crops, boron did not appear to be as serious a problem as selenium in ground water at the Ouray NWR.

\section{Water Type and Source of Selenium in Ground Water}

There are three processes by which selenium could reach large concentrations in the shallow ground water entering ponds in the North Roadside and Sheppard Bottom areas: (1) evaporation and concentration of recharge water subsequent to irrigation; (2) discharge of deep and geologically old ground water from a regional aquifer; and (3) dissolution of selenates in evaporite deposits by shallow ground water.

The evaporative concentration path shown in figure 45 was derived by simulating evaporation of water from the Ouray Park irrigation system and plotting the ratio of dissolved selenium to dissolved chloride. Chloride generally behaves conservatively, changing in concentration only by dilution and evaporative concentration processes. Water from wells NR1, NR2, NR4, and S5 plot near the evaporative concentration line, and concentrations of chloride and selenium in the water from those wells could originate by evaporation of surface water in the area. Water from other wells in the North Roadside draw and Sheppard Bottom area, however, plot much farther from the evaporative concentration line, and the large selenium concentrations and chloride in them likely could not be derived from simple evaporation of recharge water.

On the basis of major ions, there are three distinct water types for the surface-water supply and shallow wells along the western part of the refuge. The surface water supplied by the Ouray Park 
irrigation system was a sodium magnesium bicarbonate sulfate type that did not contain more than 1 $\mu \mathrm{g} / \mathrm{L}$ of selenium. Water from well NR4 had an ionic composition similar to the surface water in that it was primarily a sodium bicarbonate type that rarely contained a selenium concentration in excess of $1 \mu \mathrm{g} / \mathrm{L}$. Water from the other wells in the North Roadside draw (NR1, NR2, NR3 shallow, NR3 middepth, NR3 deep) were sodium sulfate types with selenium concentrations ranging from 7 to $830 \mu \mathrm{g} / \mathrm{L}$. Water from the S3 and S5 wells in Sheppard Bottom were sodium chloride types and typically contained dissolved-solids concentrations ranging from about 9,000 to $16,000 \mathrm{mg} / \mathrm{L}$, with selenium concentrations averaging $44 \mu \mathrm{g} / \mathrm{L}$ for well S5 and 6,700 $\mu \mathrm{g} / \mathrm{L}$ for well S3.

During evaporation, precipitation of a binary salt such as calcite results in a chemical divide. Because the binary-salt solubility product indicates that the solutes are inversely related, during precipitation, the solute with smaller concentration as precipitation begins essentially will be removed from solution while the other solute will not be removed (Drever, 1982, p. 200). Thus, evaporation and subsequent precipitation of minerals change the solution composition. Calculation of a salt norm is one means of accounting for changes in solute ratios due to mineral precipitation during evaporation. The salt norm is an idealized equilibrium assemblage of saline minerals that would result if a given water were evaporated to dryness at a standard temperature and pressure. Salt norms may identify lithologic source, the relative roles of carbonic and sulfuric acid hydrolysis in weathering waters, and the origin of connate water from normal marine or evaporite salt resolution processes, and may distinguish between dolomitization and silicate hydrolysis or exchange for diagenetic waters. A computer model, SNORM (Bodine and Jones, 1986), calculates the normative salt assemblage using the ionic composition of water.

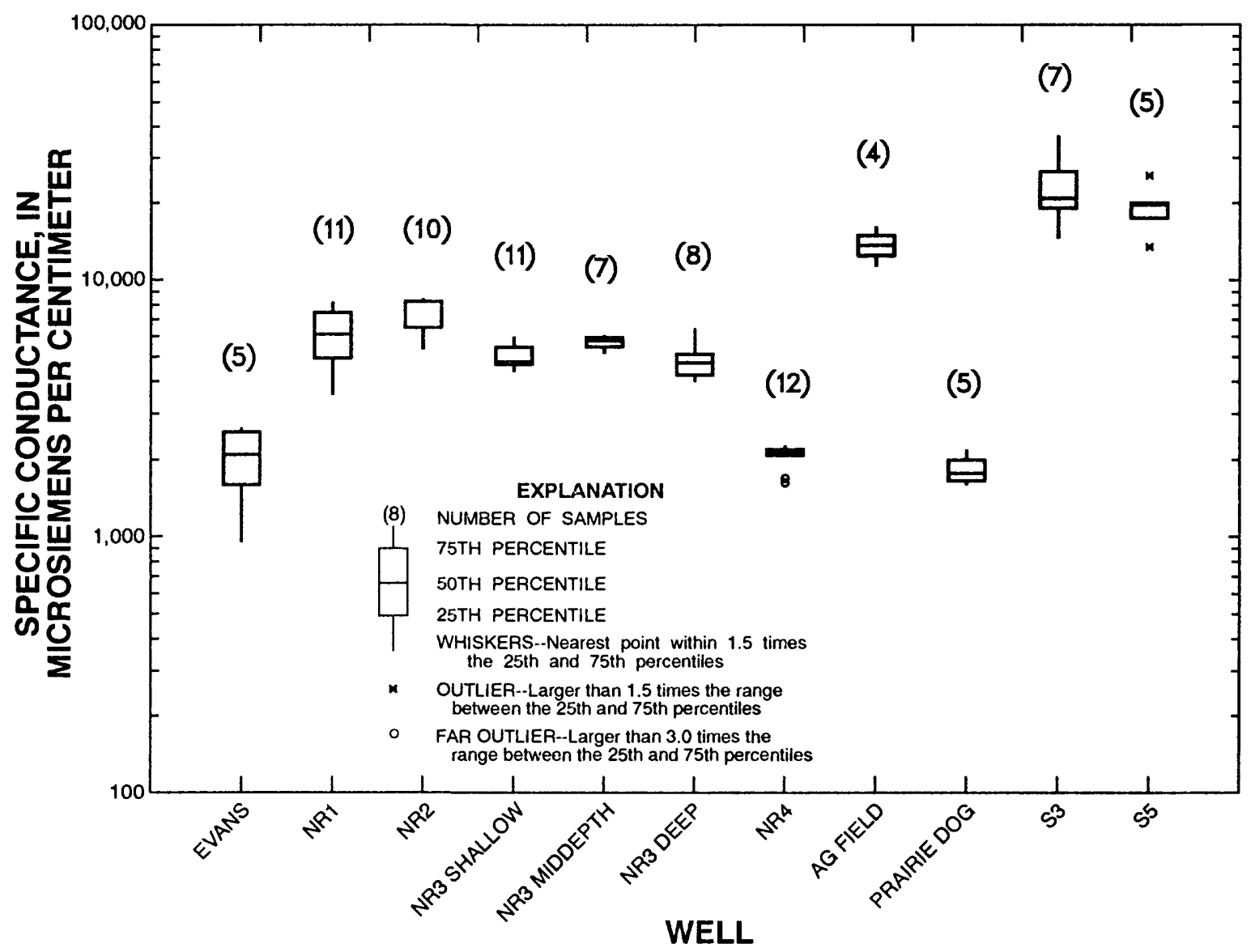

Figure 44. Specific conductance in water from wells in the area of Ouray National Wildlife Refuge, 1988-89. 
SNORM and a geochemical mass-transfer model BALANCE (Parkhurst and others, 1982) were used to determine if concentrations of common salts in surface water from Pelican Lake could result in the water types found in the shallow wells on the western part of Ouray NWR, and to identify plausible chemical reactions that would produce the observed composition of salts in these wells. Water transported from Pelican Lake by the Ouray Park irrigation system was initially a sodium magnesium, bicarbonate sulfate type water. As the sodium chloride and sodium sulfate became concentrated by evaporation, precipitation of calcite removed the bicarbonate. This precipitation resulted in water of a sodium magnesium, sulfate chloride type found in the wells at Ouray NWR; however, a plausible geochemical model could not be found that would account for the large quantity of sodium chloride found in wells such as S3. Some of the salt results from evaporation, but dissolution of halite in local soils or discharge of brine from deep formations would be required to supply the quantities observed.

Although the water types (but not the large selenium concentrations) observed in the wells could be theoretically derived by evaporation of surface water, the hydrogen and oxygen isotopic composition of the water indicated evaporation of water from Pelican Lake was not responsible. Concentrations of stable hydrogen and oxygen isotopes in water from Pelican Lake, the Evans well, and the wells at Ouray NWR are shown in figure 46. The isotopically heaviest water was from Pelican Lake. The isotopically lightest water was from the Ag Field well. Evaporation of Pelican Lake water would result in water of a heavier isotopic composition, not the lighter composition observed in all of the wells. The slope of the evaporation trend line for these data exceeded six, suggesting only a weak association with evaporation. Usually, evaporation of surface water enriches the deuterium and oxygen-18 isotopes such that the delta deuterium/delta oxygen-18 slope is between 3 and 6 (Gat, 1980,

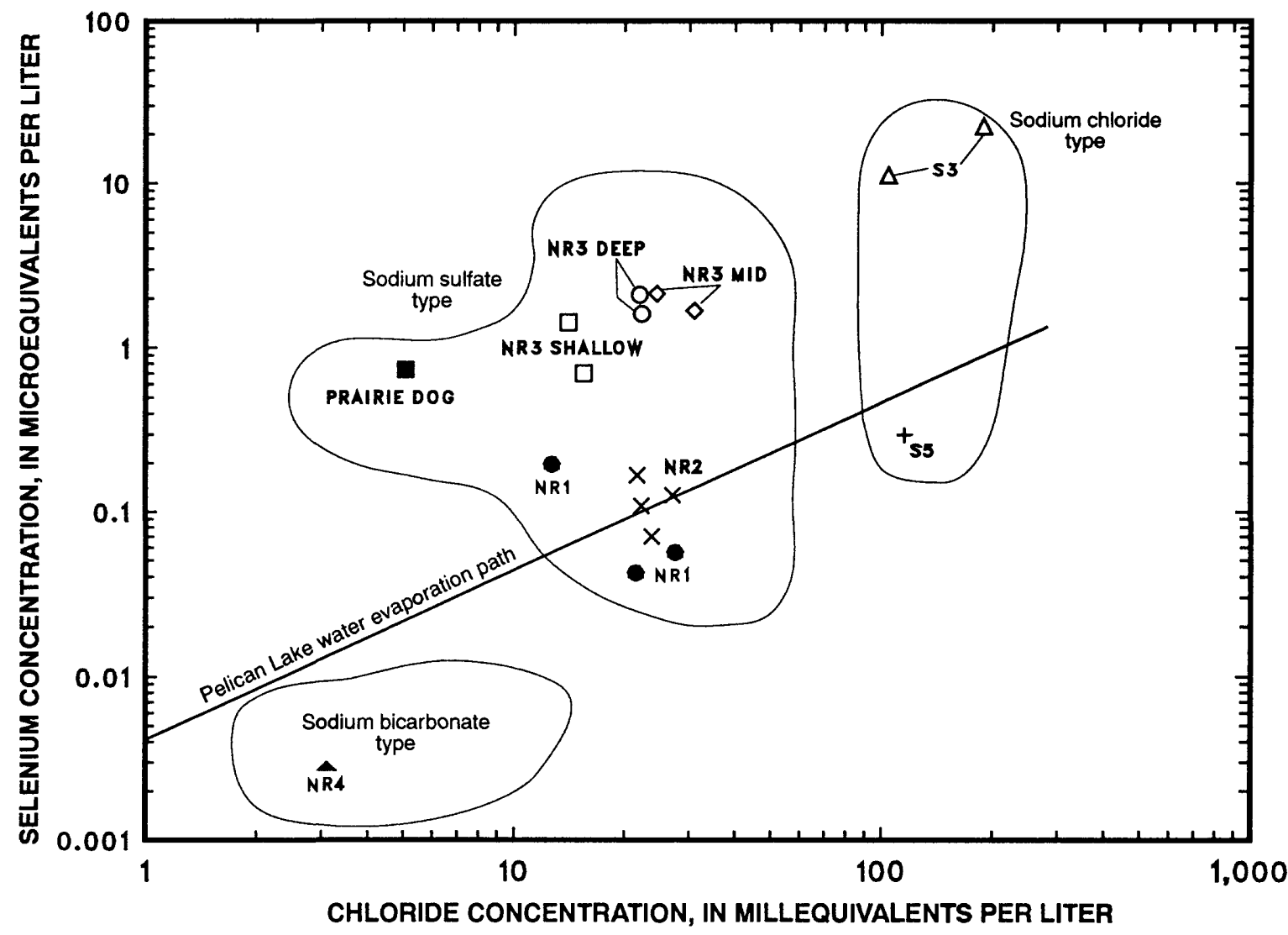

Figure 45. Evaporative concentration of selenium and chloride in irrigation-source water (Pelican Lake) related to measured concentration of selenium and chloride in water from shallow wells in the area of Ouray National Wildlife Refuge. 


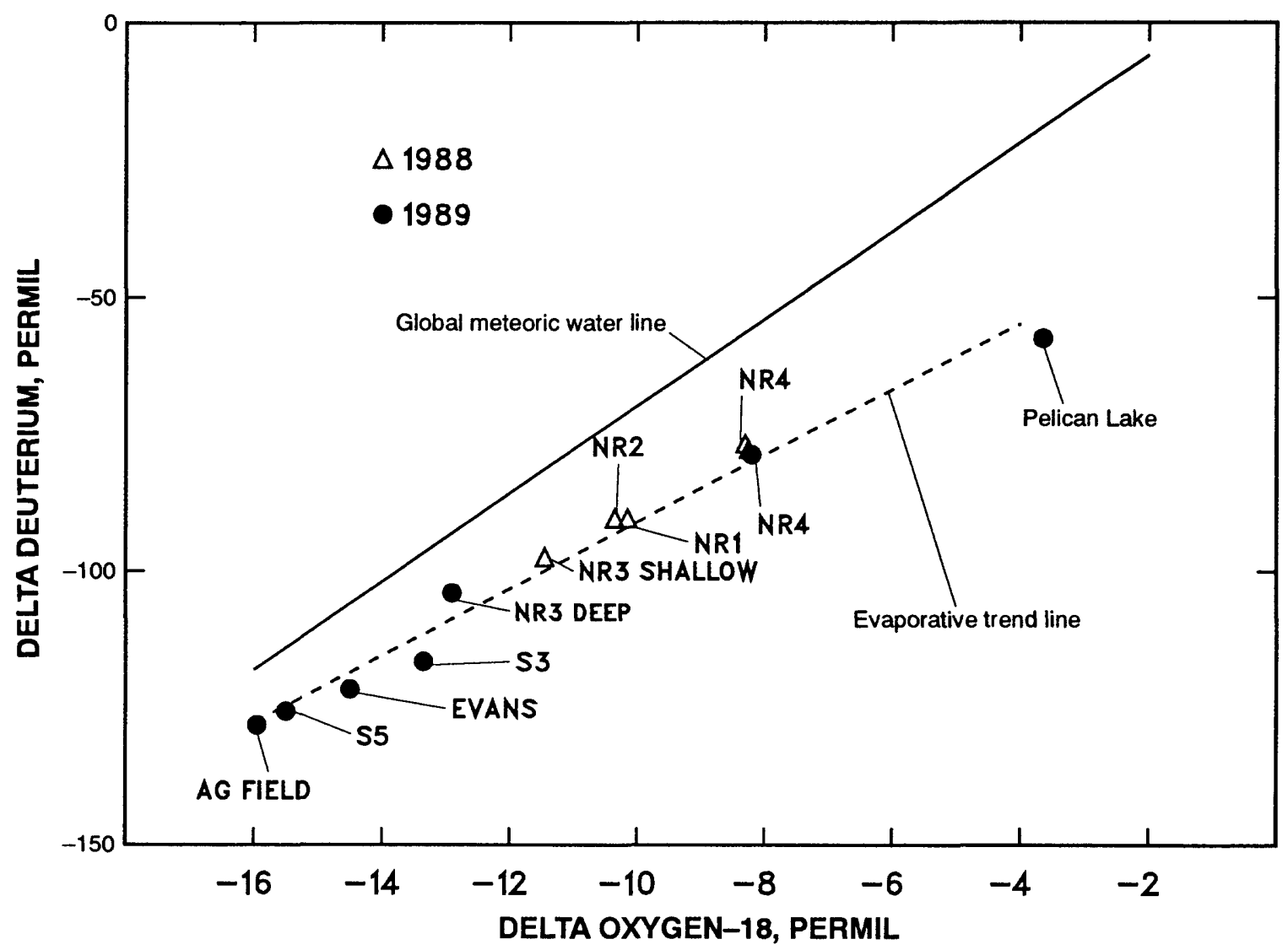

Figure 46. Relation of delta deuterium to delta oxygen-18 for water samples from Pelican Lake and wells at Ouray National Wildlife Refuge, 1988 and 1989.

p. 37). The coefficient of determination for the relation of delta deuterium to delta oxygen-18 in water from the Ouray wells is 0.98 , suggesting a common origin.

The source of water in the Ag Field well during early spring was believed to be shallow ground water moving from topographically higher recharge areas to the Green River $0.7 \mathrm{mi}$ to the east. Water from the Ag Field well was isotopically lighter than any water sampled in the area and contained selenium concentrations that were near the reporting level of $1 \mu \mathrm{g} / \mathrm{L}$. Water from the $\mathrm{Ag}$ Field well contained 6.7 tritium units, and water from the NR3 mid and deep wells near the northwest corner of the Ouray NWR contained 16 and 21 tritium units. The tritium data, while somewhat ambiguous, suggest that water from the Ag Field well may be older than ground water from the western part of the refuge. The isotopic composition of the water, the distinctively different water type, and the lack of selenium suggest that ground water from this well moves through geologic deposits considerably different from those found on the western border of Ouray NWR. Geologic deposits near the Ag Field well likely contain large quantities of sodium chloride and sulfate but do not contain appreciable quantities of selenium.

All monitoring wells near Ouray NWR except the Batty and Evans wells were installed for this study and usually were drilled to a depth where clays impeded penetration of the auger. On the basis of a model-derived ground-water budget for an area of the Uinta Basin immediately south of Ouray, Holmes and Kimball (1987, p. 7) determined that only 7 percent of the recharge to the alluvial aquifer was due to leakage from the underlying consolidated-rock aquifers. It is unlikely that a significant volume of saline water containing large selenium concentrations is moving from the deep, regional aquifer into the shallow aquifer draining the alluvial soils near Ouray NWR. Water in the wells is likely of local (Pelican Lake source) and shallow origin. 


\section{Quality of Surface Water}

Selenium concentrations in surface water at Ouray NWR were variable and depended on the water source (fig. 47). Selenium concentrations in water from Pelican Lake supplied through the Ouray Park Canal for irrigation in the Sheppard Bottom area did not exceed $1 \mu \mathrm{g} / \mathrm{L}$. Concentrations were less than $3 \mu \mathrm{g} / \mathrm{L}$ in ponds in the Leota Bottom area that receive water from the Green River. Selenium concentrations discharged from the North and South Roadside Ponds were generally large with median concentrations near $40 \mu \mathrm{g} / \mathrm{L}$. During non-irrigation periods, the ponds received no surface water and were dependent on seepage of shallow ground water. During irrigation periods, some surface water may flow into the North Roadside Pond and through the outlet into the South Roadside Pond, or may move as seepage through the dike. The discharge through the outlet structure from the North Roadside Pond to the South Roadside Pond varied with season, typically about $0.3 \mathrm{ft}^{3} / \mathrm{s}$ during non-irrigation periods and as much as $4 \mathrm{ft}^{3} / \mathrm{s}$ during summer. The surface inflow to the North Roadside Pond was sampled four times, and the selenium concentration did not exceed $1 \mu \mathrm{g} / \mathrm{L}$ in any of the samples.

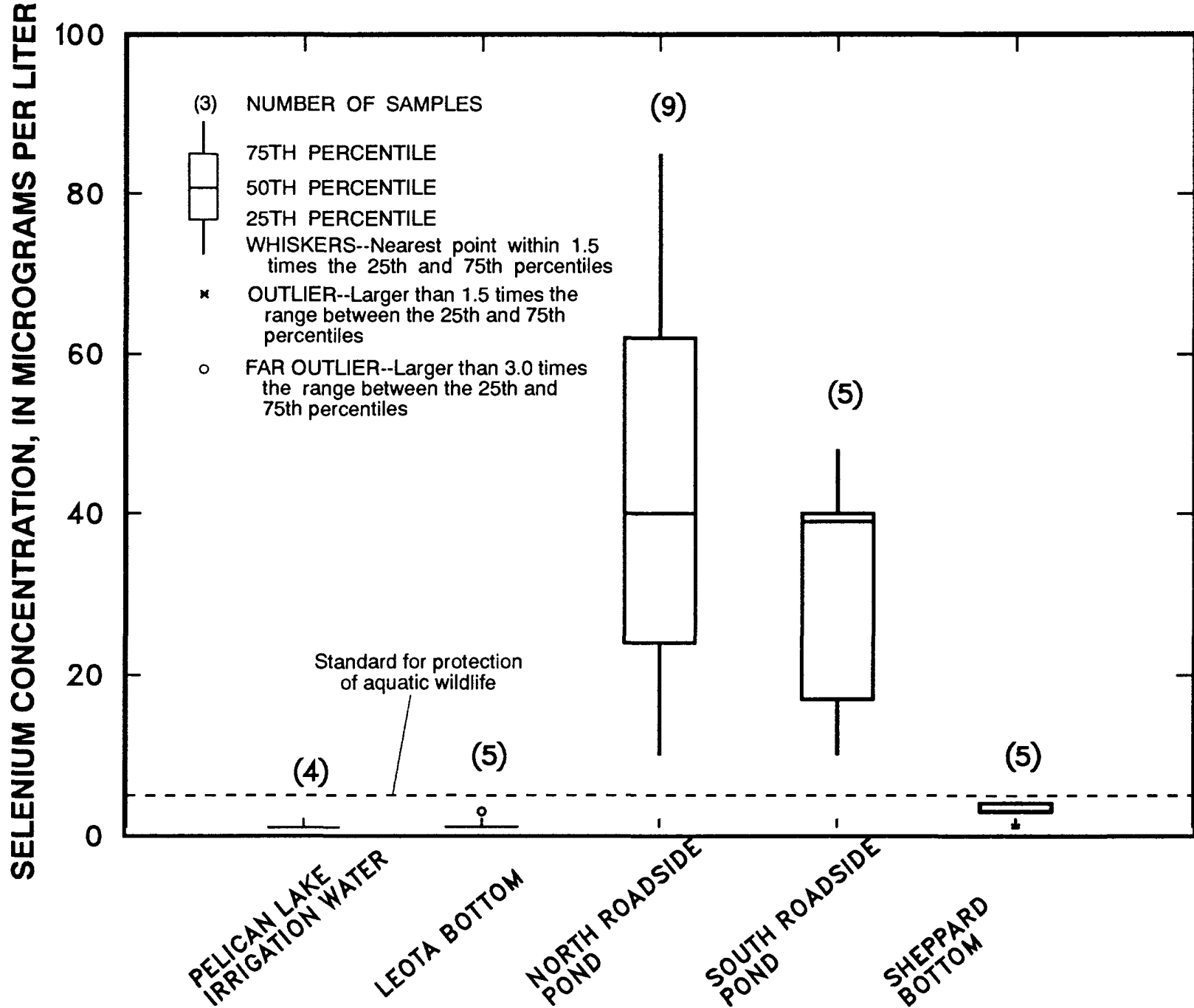

Figure 47. Selenium concentrations in surface water entering Ouray National Wildlife Refuge and in ponds in the Leota Bottom, Roadside Pond, and Sheppard Bottom areas during 1988 and 1989. 
Ponds in the Sheppard Bottom area receive water primarily from the Green River through a pump discharging into a canal that enters the $\mathrm{S} 1$ pond. Water from this pond may then enter ponds S2, S3, and S4 (fig. 8). Typically, water in pond S5 entered as surface flow from the South Roadside Pond and as ground-water seepage. Pond S3 also received water from pond S5 and from seepage. Selenium concentrations in water samples from the S3 and S5 ponds did not exceed $4 \mu \mathrm{g} / \mathrm{L}$. Seepage at two sites along the western edge of the S3 pond contained selenium concentrations of 25 and $73 \mu \mathrm{g} / \mathrm{L}$; a seep near pond S5 contained $<1 \mu \mathrm{g} / \mathrm{L}$. The relatively large volume of water that entered the S3 and S5 ponds from the Green River diluted seepage that contained generally large quantities of selenium.

A small number of water samples from ponds at Ouray NWR were analyzed for natural uranium or gross alpha radioactivity. Two of five samples from four ponds contained a gross alpha activity that exceeded the Utah standard of $15 \mathrm{pCi} / \mathrm{L}$ established for the protection of aquatic wildlife. The outflow from the North Roadside Pond contained $38 \mathrm{pCi} / \mathrm{L}$ when sampled in April 1988, and Sheppard Pond S3 contained $19 \mathrm{pCi} / \mathrm{L}$ in August 1987. The concentration of $2 \mathrm{pCi} / \mathrm{L}$ from Leota Pond L3 was the smallest concentration measured at any of 15 sites in the middle Green River basin during the 1986-89 study. The specific source of the radioactivity is not known, but uranium and radium concentrations are enriched in at least 80 formations in the Colorado Plateau (Stokes, 1986, p. 128).

\section{Water Quality in Leota Bottom: an Uncontaminated Area}

Concentrations of many elements and compounds in water of the middle Green River basin are larger than concentrations in water elsewhere in Utah as a result of dissolution of evaporite minerals commonly found in the Colorado Plateau. For some elements, notably selenium and boron, the background concentrations in the middle Green River basin are considerably larger than those typically found in non-contaminated areas. Concentrations of some constituents from contaminated areas are more appropriately compared to concentrations from a non-contaminated area within the Colorado Plateau than from non-contaminated sites in other areas.

Leota Bottom at Ouray NWR represents an area with a typical background for concentrations of evaporite minerals in water in the absence of contamination by human activities. Water in Leota Bottom is pumped from the Green River and therefore represents a composite of water types found in the Colorado Plateau. The ranges for selected water-quality parameters in ponds in Leota Bottom are compared to the Roadside Ponds, areas of known contamination by selenium, in table 21 . As expected, the range of values for specific conductance, sodium, sulfate, boron, and selenium were larger in the Roadside Ponds than in ponds in Leota Bottom. Concentrations of fluoride, arsenic, barium, and molybdenum, however were larger in ponds in Leota Bottom. The reasons for the increased concentration of these elements in Leota Bottom are not known but may be related to the alluvial soils deposited by the Green River that underlie the area.

\section{Trace Elements in Bottom Sediment}

Concentrations of most elements in bottom sediment from Ouray NWR (table 22) were within the usual range for soils in the area as defined by the 95 percent confidence interval for data assembled by Tidball and Severson (1982); however, selenium concentrations at all sites exceeded the background concentration of $0.058 \mu \mathrm{g} / \mathrm{g}$ for typical soils in the Piceance and Uinta Basins. The largest concentration, $17 \mu \mathrm{g} / \mathrm{g}$ from the North Roadside Pond, was almost 300 times larger than the upper limit of the confidence interval. The smallest concentration $(<0.1 \mu \mathrm{g} / \mathrm{g})$ was collected in the draw north of North Roadside Pond near the north boundary of the refuge.

The aluminum concentration of 6 percent in bottom sediment from the L3 pond in Leota Bottom slightly exceeded the upper confidence interval of 5.8 percent for aluminum in soils in the area. No other elements were present in concentrations that exceeded the usual range for soils in the area.

There was a generally positive relation between concentrations of selenium in pond sediment at Ouray NWR and concentrations of organic material in the sediments. Bottom sediment samples were collected in March 1989 from selected sites in the North and South Roadside Ponds and analyzed 
Table 21. Range of measurements for selected water-quality properties and constituents in water samples from two ponds (4 to 7 samples) in Leota Bottom and from the North and South Roadside Ponds (5 to 20 samples) at Ouray National Wildlife Refuge, 1987-89

[ $\mu \mathrm{S} / \mathrm{cm}$, microsiemens per centimeter; $\mathrm{mg} / \mathrm{L}$, milligrams per liter; $\mu \mathrm{g} / \mathrm{L}$, micrograms per liter]

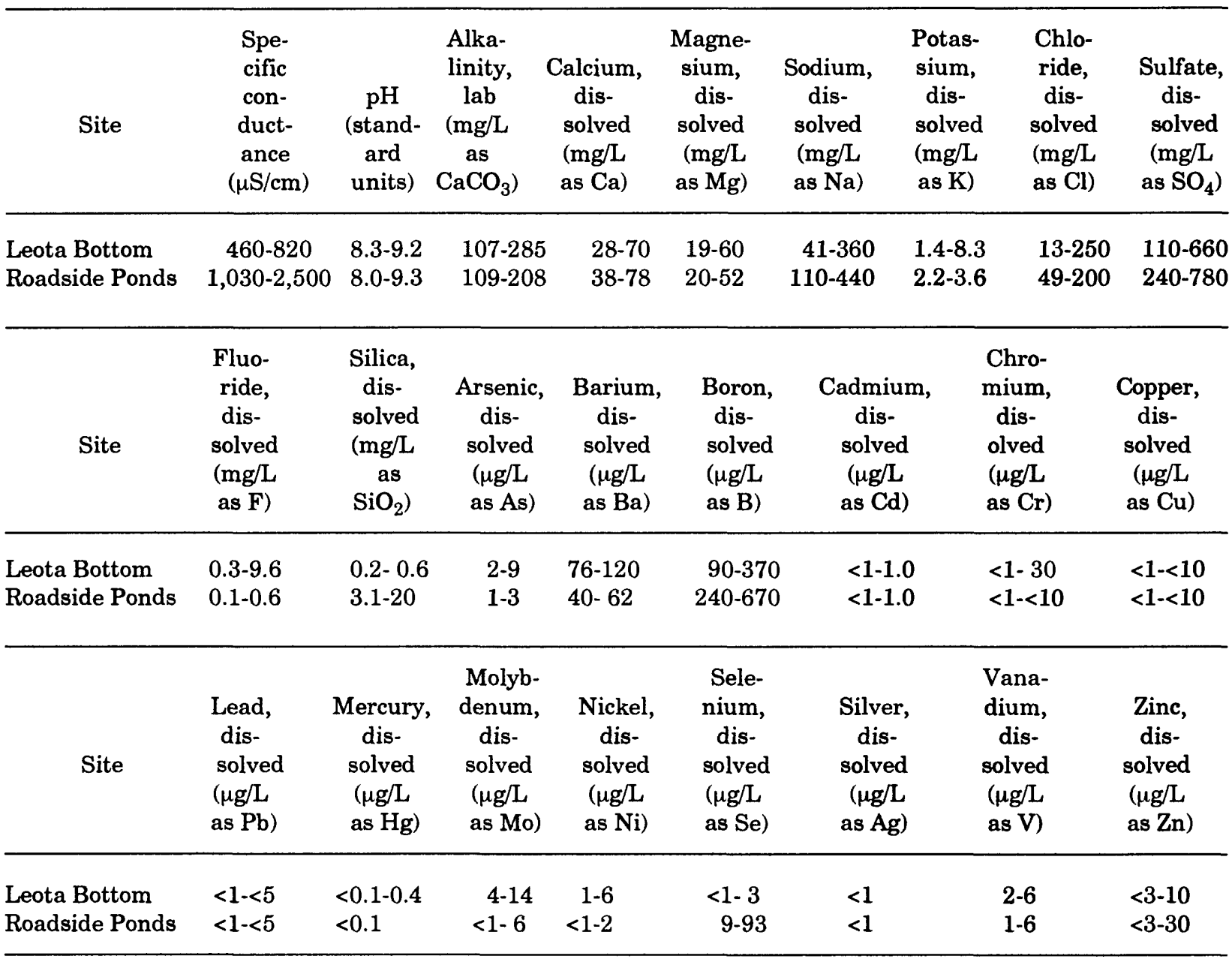

for selenium and total volatile solids (an estimate of organic material). Selenium concentrations increased as the quantity of organic material increased, up to a volatile solids content of about $80 \mu \mathrm{g} / \mathrm{g}$ (fig. 48). Selenium concentrations then remained relatively constant. The association of selenium with organic matter suggests a biological process may be involved in removing selenium from the water and deposition in sediment. This process could be an active deposition of elemental selenium as part of a bacterial-respiratory process described by Oremland and others (1989), selenium removal by vegetation followed by degradation, or a geochemical process associated with the reducing conditions of biological decay.

\section{Association of Selenium with Soil Type Near Pelican Lake and Ouray}

Soils in the area of Pelican Lake and Ouray are composed primarily of Holocene alluvium and colluvium 1- to 100-ft thick deposited on present-day floodplains. The underlying bedrock (and the source of the alluvium) is the locally intertonguing Duchesne River and Uinta Formations. Both formations are composed of shale, siltstone, and sandstone. Rosenfeld and Beath $(1964$, p. 26) indicate 
Table 22. Concentrations of trace elements and radionuclides in the less than 62-micron fraction of sediment samples collected from Leota L3 pond, S5 inflow canal, Sheppard S3 pond, North Roadside Pond, and North Roadside draw at Ouray National Wildlife Refuge

[These concentrations are compared with the 95-percent confidence interval for soil in the Piceance Basin, Colorado, and the Uinta Basin, Utah. Values are for total concentrations in micrograms per gram, which is equal to parts per million. Data for soil are from the Uinta Basin and from the Piceance Basin, 80 miles southeast of the study area in Colorado (Tidball and Severson, 1982); -, not available; $<$, less than reporting value]

\begin{tabular}{|c|c|c|c|c|c|c|}
\hline Constituent & $\begin{array}{l}\text { Leota } \\
\text { L3 } \\
\text { pond }\end{array}$ & $\begin{array}{c}\text { S5 } \\
\text { inflow } \\
\text { canal }\end{array}$ & $\begin{array}{l}\text { Sheppard } \\
\text { S3 pond }\end{array}$ & $\begin{array}{c}\text { North } \\
\text { Roadside } \\
\text { Pond }\end{array}$ & $\begin{array}{c}\text { North } \\
\text { Roadside } \\
\text { draw }\end{array}$ & $\begin{array}{l}\text { Soils in Piceance } \\
\text { and Uinta Basins }\end{array}$ \\
\hline
\end{tabular}

\begin{tabular}{|c|c|c|c|c|c|c|}
\hline \multicolumn{7}{|c|}{ Concentration in micrograms per gram } \\
\hline Arsenic & 5.9 & 3.0 & 5.0 & 2.1 & 3.0 & 3.5 to 25 \\
\hline Barium & 700 & 730 & 730 & 600 & 570 & 640 to 2,250 \\
\hline Beryllium & 2 & $<1$ & 1 & $<1$ & $<1$ & 1.1 to 5.3 \\
\hline Bismuth & $<10$ & $<10$ & $<10$ & $<10$ & $<10$ & - \\
\hline Cadmium & $<2$ & $<2$ & $<2$ & $<2$ & $<2$ & - \\
\hline Cerium & 64 & 79 & 55 & 42 & 51 & 25 to 110 \\
\hline Chromium & 59 & 28 & 50 & 24 & 30 & 27 to 94 \\
\hline Cobalt & 10 & 5 & 8 & 4 & 5 & 4.4 to 12 \\
\hline Copper & 21 & 7 & 14 & 10 & 12 & 9.5 to 95 \\
\hline Europium & $<2$ & $<2$ & $<2$ & $<2$ & $<2$ & - \\
\hline Gallium & 14 & 8 & 13 & 8 & 8 & 8.6 to 26 \\
\hline Gold & $<8$ & $<8$ & $<8$ & $<8$ & $<8$ & - \\
\hline Holmium & $<4$ & $<4$ & $<4$ & $<4$ & $<4$ & - \\
\hline Lanthanum & 36 & 46 & 32 & 26 & 31 & 29 to 52 \\
\hline Lead & 19 & 12 & 16 & 11 & 10 & 4.5 to 32 \\
\hline Lithium & 34 & 13 & 28 & 13 & 19 & 14 to 100 \\
\hline Manganese & 450 & 230 & 380 & 99 & 170 & - \\
\hline Molybdenum & 2 & $<2$ & $<2$ & $<2$ & $<2$ & 2.7 to 12 \\
\hline Neodymium & 29 & 32 & 24 & 17 & 22 & - \\
\hline Nickel & 22 & 7 & 18 & 7 & 9 & 9.9 to 40 \\
\hline Niobium & 5 & $<4$ & 7 & $<4$ & 4 & - \\
\hline Scandium & 8 & 4 & 7 & 4 & 4 & 5.5 to 11 \\
\hline Selenium & .7 & 3.0 & .6 & 17 & $<.1$ & .01 to .058 \\
\hline Silver & $<2$ & $<2$ & $<2$ & $<2$ & $<2$ & - \\
\hline Strontium & 320 & 270 & 350 & 250 & 230 & 190 to 740 \\
\hline Tantalum & $<40$ & $<40$ & $<40$ & $<40$ & $<40$ & - \\
\hline Thorium & 11 & 12 & 10 & 5 & 8 & 5.5 to 16 \\
\hline Tin & $<10$ & $<10$ & $<10$ & $<10$ & $<10$ & - \\
\hline Uranium & $<100$ & $<100$ & $<100$ & $<100$ & $<100$ & 2.4 to 5.2 \\
\hline Vanadium & 72 & 31 & 57 & 28 & 35 & 40 to 120 \\
\hline Ytterbium & 2 & 1 & 2 & $<1$ & 1 & 1.4 to 4.6 \\
\hline Yttrium & 18 & 12 & 15 & 8 & 10 & 11 to 29 \\
\hline Zinc & 73 & 25 & 66 & 27 & 30 & 33 to 110 \\
\hline \multicolumn{7}{|c|}{ Concentration in weight percent } \\
\hline Aluminum & 6.0 & 3.8 & 5.6 & 3.7 & 3.9 & 3.4 to 5.8 \\
\hline Calcium & 4.7 & 2.9 & 4.0 & 1.4 & 2.3 & .001 to 11 \\
\hline Iron & 2.2 & 1.2 & 1.9 & .94 & 1.3 & 1 to 3 \\
\hline Magnesium & 1.3 & .57 & 1.1 & .49 & .68 & .45 to 3.9 \\
\hline Phosphorus & .09 & .05 & .08 & .05 & .04 & - \\
\hline Potassium & 2.0 & 1.8 & 2.0 & 1.5 & 1.4 & 1.2 to 3 \\
\hline Sodium & .80 & .89 & .96 & .85 & .68 & .14 to 2.1 \\
\hline Titanium & .23 & .12 & .18 & .1 & .13 & .21 to .33 \\
\hline
\end{tabular}




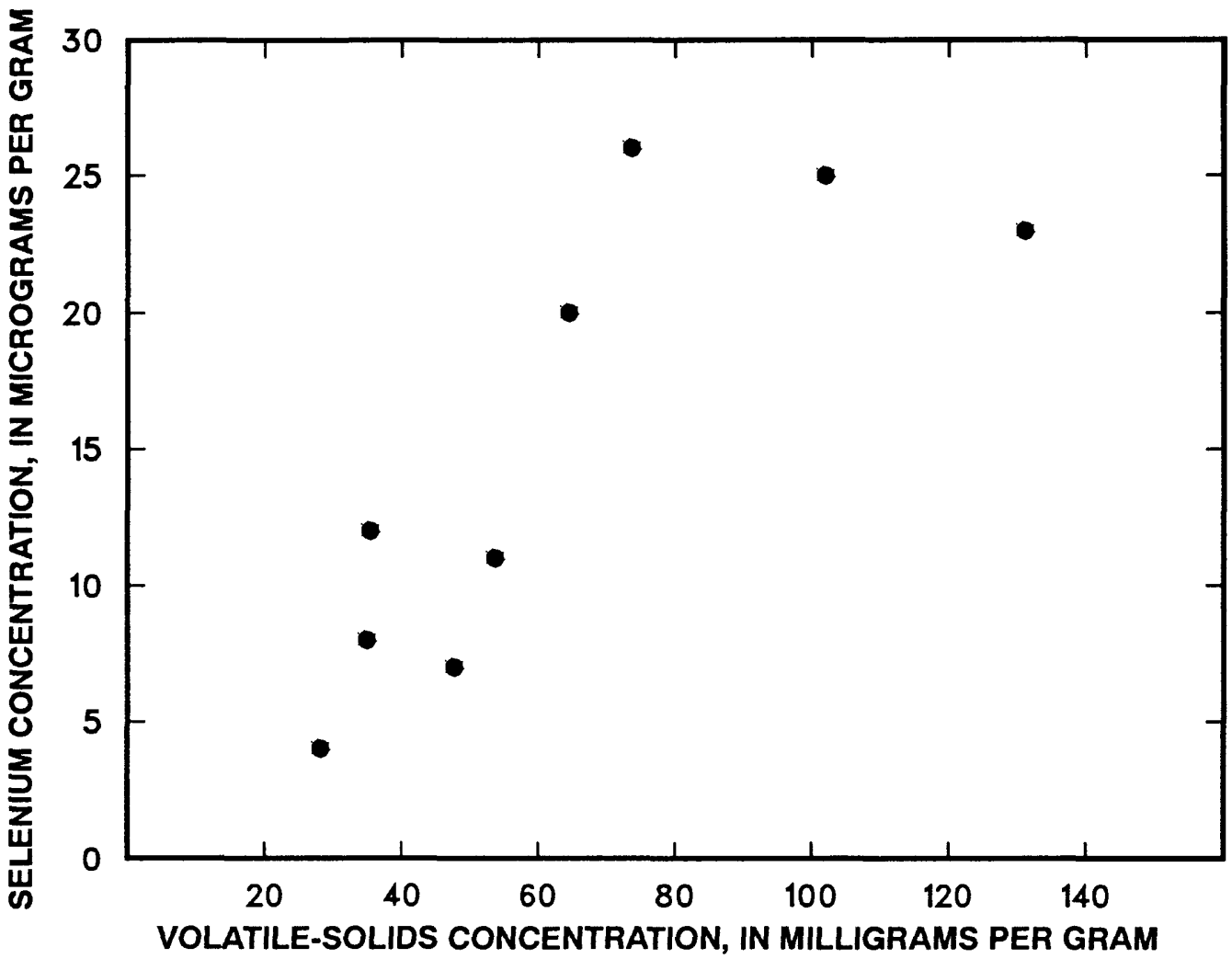

Figure 48. Concentrations of selenium and volatile solids in bottom sediment from North and South Roadside Ponds at Ouray National Wildlife Refuge.

that both formations may be seleniferous in areas. The non-uniform distribution of selenium in the parent material and derived soils contrasts with the close association of selenium in soils of the Vernal and Jensen areas.

The association of large selenium concentrations in water with specific soil types is weak. Alkali salts exist to some extent in nearly all the soils of the area, and the presence of alkali does not appear to have any relation to the chemical composition of the parent rock (Hendrickson and others, 1925, p. 1497). Natural drainage conditions are adequate except for a few areas that include the lake bed of Pelican Lake and associated smaller low areas south of the lake that have no drainage outlet. These inadequately drained areas are underlain by Winslow clay, a very compact brown clay that impedes the downward movement of water (Hendrickson and others, 1925, p. 1514). The clay layer under Pelican Lake greatly reduces water loss to the alluvial aquifer. Large selenium concentrations in water were found in two wells southeast of Pelican Lake, $1.5 \mathrm{mi}$ north of Ouray NWR. These wells contained selenium concentrations of 3 to $93 \mu \mathrm{g} / \mathrm{L}$ and are completed in Bennett and Sheppard fine sand. They were drilled and cased to a gravel and clay layer at a depth of about $60 \mathrm{ft}$. The other contaminated sites were limited to Ouray NWR.

Selenium contamination of water at Ouray NWR was limited to a narrow strip of drainage near the west border and two shallow wells in the western part of Sheppard Bottom. Selenium concentrations in shallow wells used to monitor seepage into the North Roadside Pond at the refuge have ranged from 1 to $830 \mu \mathrm{g} / \mathrm{L}$. These wells are 6 to $43 \mathrm{ft}$ deep, and the deepest is believed to be completed near the top of the underlying shale. All of these wells are in a narrow strip of Naples fine sand. Water from well NR4, drilled adjacent to the North Roadside Pond, has never contained more than $15 \mu \mathrm{g} / \mathrm{L}$ of selenium. This well also appears to be in the same soil type. 
Sheppard Bottom was the only other section of the refuge where large selenium concentrations have been found in surface or shallow ground water. Selenium concentrations in two wells in this area have ranged from 25 to $9,300 \mu \mathrm{g} / \mathrm{L}$. These wells are finished in soils of Mesa fine sand and Mesa fine sandy loam. Compared with soils near Jensen, selenium concentrations in soils near Ouray NWR are small. Drill cuttings from shallow wells drilled in Bennett, Sheppard, and Naples fine sand contained selenium concentrations less than the reporting level of $1 \mu \mathrm{g} / \mathrm{g}(1,000 \mathrm{ppb})$. There is, however, a small soil section of Chipeta clay origin $1 \mathrm{mi}$ west and upgradient of the Roadside Ponds (Hendrickson and others, 1925, Soil Map). The selenium content of a single sample of Chipeta clay from western Colorado was $3 \mu \mathrm{g} / \mathrm{g}(3,000 \mathrm{ppb})$ (Williams and Byers, 1935, p. 432). It is possible that Chipeta clay and soil with a similar origin occur randomly in the alluvium near the west border of the refuge and provide the source for the selenium that is mobilized in the shallow ground water.

\title{
Biological Observations and Contamination in Biota
}

\author{
Nesting Observations at Pelican Lake
}

Nesting observations made at Pelican Lake, about 4 mi north of Ouray NWR, primarily included nests of American coots and pied-billed grebes in 1987. A total of 34 nests were monitored: 29 American coot nests, 4 pied-billed grebe nests, and 1 ruddy duck (Oxyura jamaicensis) nest.

Nesting success (at least one egg hatched) at Pelican Lake was estimated to be 59 percent (table 23). Predation accounted for 32 percent of all nest failures. One nest contained three dead American coot embryos that appeared to be normal in development, but tissues were not analyzed. Two live, newly hatched chicks from the same nest were examined and also appeared normal. Seven eggs in the ruddy duck nest failed to hatch. It is believed that these eggs were added to the nest after incubation of previously laid eggs had been initiated and that they died when incubation was terminated after the first group of eggs hatched.

\section{Residue in Biota from Pelican Lake}

Single eggs were collected randomly from nine American coot nests, and three eggs were collected non-randomly. Geometric mean selenium concentrations in the eggs were 1.5 and $1.9 \mu \mathrm{g} / \mathrm{g}$, respectively (table 24), and ranged from 0.8 to $2.6 \mu \mathrm{g} / \mathrm{g}$ (dry weight) (Peltz and Waddell, 1991, p. 119). One sample of yellow-headed blackbird leave eggs (unhatched eggs left in the nest after incubation was completed) collected near the inlet to Pelican Lake contained $4.3 \mu \mathrm{g} / \mathrm{g}$ of selenium.

One adult American coot was found dead during the nesting surveys, but its origin was uncertain. The dead coot was collected June 16,1987, and had a selenium concentration of $108 \mu \mathrm{g} / \mathrm{g}$ in its liver. A necropsy performed by the National Wildlife Health Laboratory concluded that selenium poisoning was the underlying cause of death. It is likely that this bird did not originate from Pelican Lake because other samples from there contained very small quantities of selenium.

Liver samples were collected August 12 and analyzed from eight presumed-resident American coots (one adult and seven juveniles), an adult ruddy duck, and a composite of two juvenile ruddy ducks. Selenium concentrations in these samples were small, ranging from less than 2.2 to $5.7 \mu \mathrm{g} / \mathrm{g}$ (dry weight) (Peltz and Waddell, 1991, p. 115). Collections of American coots were made near the inlet and outlet of Pelican Lake. Those collected near the inlet had a geometric mean of $3.1 \mu \mathrm{g} / \mathrm{g}$, and birds collected near the outlet had a geometric mean of $3.2 \mu \mathrm{g} / \mathrm{g}$.

Liver and muscle tissue was collected and analyzed from three northern shovelers, which were taken as soon as they were available during the spring migration. The birds had geometric mean selenium concentrations of $10.1 \mu \mathrm{g} / \mathrm{g}$ and $2.2 \mu \mathrm{g} / \mathrm{g}$ (dry weight) in the liver and muscle tissue, respectively. 
Selenium concentrations in whole-body fish samples from Pelican Lake ranged from 2.1 to 2.5 $\mu \mathrm{g} / \mathrm{g}$ (Peltz and Waddell, 1991, p. 115), with a geometric mean of $2.3 \mu \mathrm{g} / \mathrm{g}$ for largemouth bass and bluegill (table 24). Fish were collected at the south shore of Pelican Lake in the vicinity of the outlet structure and along the north shore near the inlet. Selenium concentrations in whole-body bluegill (Lepomis macrochirus) were slightly larger in samples taken near the inlet $(2.4 \mu \mathrm{g} / \mathrm{g})$ than in samples taken near the outlet $(2.2 \mu \mathrm{g} / \mathrm{g})$. Similarly, selenium concentrations in whole-body largemouth bass (Micropterus salmoides) were 2.5 and $2.1 \mu \mathrm{g} / \mathrm{g}$ at the same sites near the inlet and outlet (Peltz and Waddell, 1991, p. 115).

Because of the local and regional importance of the fishery in Pelican Lake, fillets of largemouth bass and bluegill were taken. Concentrations of elements analyzed were reported in Peltz and Waddell (1991) and were generally small and similar in all samples; however, three of the six samples had mercury concentrations that exceeded $1 \mu \mathrm{g} / \mathrm{g}$ and ranged as large as $1.83 \mu \mathrm{g} / \mathrm{g}(0.41 \mu \mathrm{g} / \mathrm{g}$ wet weight) (table 24). This was substantially less than the Food and Drug Administration recommended action level of $1 \mu \mathrm{g} / \mathrm{g}$ wet weight. All fish samples collected near the inlet had larger mercury concentrations than samples of the same species and type of sample (for example, fillet or whole body) collected near the outlet.

Plant samples were taken in close proximity to the outlet structure at Pelican Lake and near the inlet. Geometric mean selenium concentrations in individual taxa were small and ranged from 0.3 to $0.6 \mu \mathrm{g} / \mathrm{g}$ (dry weight) (table 24). The maximum boron concentration was $667 \mu \mathrm{g} / \mathrm{g}$ in potamogeton. Geometric mean selenium concentrations were small in invertebrates, ranging from $0.5 \mu \mathrm{g} / \mathrm{g}$ for snails to $2.9 \mu \mathrm{g} / \mathrm{g}$ for odonates.

\section{Nesting Observations in Leota Bottom at Ouray National Wildlife Refuge}

Nesting studies were begun in 1987 and completed in 1989. The primary emphasis was on locating nests of American coot and pied-billed grebe; however, some data were obtained on blackcrowned night herons. A total of 121 American coot nests were monitored. These were equally distributed in ponds L3, L6, L7, and L8, except pond L5 where only 10 nests were monitored (fig. 8) (table 25). Overall, at least 66 percent of American coot nests were successful in hatching at least one egg. Nesting success among ponds ranged from 10 percent at pond L5 to 83 percent at pond L8. Predation was generally the cause of nesting failure, affecting about 26 percent of the nests. Not all nests in each pond were located and monitored; however, because of the uniform distribution of search effort, these data are believed to represent all ponds except pond L5. Searches conducted in pond L5 were primarily near borrow ditches and may be skewed toward a higher percentage of predation losses and therefore smaller success rates. Only three (less than 1 percent of all eggs) American coot eggs that were examined failed to hatch, and no deformed embryos were observed.

Table 23. Nesting success of waterbirds at Pelican Lake, 1987

[Percent success: percentage of monitored nests known to hatch at least one egg; - , not applicable]

\begin{tabular}{lcc}
\hline \multicolumn{1}{c}{ Species } & $\begin{array}{c}\text { Monitored } \\
\text { nests }\end{array}$ & $\begin{array}{c}\text { Percent } \\
\text { success }\end{array}$ \\
\hline American coot & 29 & 62 \\
Pied-billed grebe & 4 & 25 \\
Ruddy duck & 1 & 100 \\
$\quad$ Total & 34 & - \\
$\quad$ Success for all nests combined & - & 59 \\
\hline
\end{tabular}


Table 24. Geometric mean selenium concentrations in biological samples from Pelican Lake and in fish samples collected nationwide by the National Contaminant Biomonitoring Program

[mm, millimeter; g, gram; $\mu \mathrm{g} / \mathrm{g}$, micrograms per gram (dry weight); -, not specified; ${ }^{*}$, single real data point; NCBP, National Contaminant Biomonitoring Program, from Schmitt and Brumbaugh, 1990

(1984 geometric mean concentration, 85th percentile, converted to dry weight using 75 percent moisture). Mean length, weight, and moisture content are arithmetic means]

Species: NR, non-random sampling; R, random sampling; LV, liver; MS, muscle; WB, whole body

Site name: PL, Pelican Lake; PL IN, Pelican Lake inlet; PL OUT, Pelican Lake outlet

\begin{tabular}{|c|c|c|c|c|c|c|c|}
\hline Species & $\begin{array}{c}\text { Site } \\
\text { name }\end{array}$ & $\begin{array}{l}\text { Sample } \\
\text { size }\end{array}$ & $\begin{array}{c}\text { Sample } \\
\text { type }\end{array}$ & $\begin{array}{l}\text { Mean } \\
\text { length } \\
(\mathrm{mm})\end{array}$ & $\begin{array}{l}\text { Mean } \\
\text { weight } \\
\text { (g) }\end{array}$ & $\begin{array}{l}\text { Mean } \\
\text { moisture } \\
\text { content } \\
\text { (percent) }\end{array}$ & $\begin{array}{c}\text { Geometric } \\
\text { mean selenium } \\
\text { concentration } \\
(\mu \mathrm{g} / \mathrm{g})\end{array}$ \\
\hline
\end{tabular}

\section{American coot (NR) \\ American coot (R) \\ Yellow-headed blackbird (NR)}

American coot (LV), Summer

American coot (LV), Spring

American coot (LV)

Northern shoveler (LV)

Northern shoveler (MS)

Ruddy duck (LV)

Largemouth bass (MS)

Largemouth bass (WB)

Bluegill (MS)

Bluegill (WB)

Fish, NCBP nationwide

Chara

Filamentous green algae

Potamogeton/Widgeongrass

Odonata

Snails

\section{Bird eggs}

$\begin{array}{lllllll}\text { PL } & 3 & \text { Individual } & 48.7 & - & 76.9 & 1.9 \\ \text { PL } & 9 & \text { Individual } & 49.1 & - & 75.8 & 1.5 \\ \text { PL } & 1 & \text { Individual } & - & - & 81.5 & 4.3\end{array}$

\section{Bird tissue}

$\begin{array}{ll}\text { PL IN } & 4 \\ \text { PL IN } & 1 \\ \text { PL OUT } & 4 \\ \text { PL } & 3 \\ \text { PL } & 3 \\ \text { PL IN } & 2\end{array}$

Individual

$\begin{array}{lll}-\quad & - & 69.9\end{array}$

$\begin{array}{lll}- & - & 73.9\end{array}$

- $\quad-\quad 70.9$

Individual

Individual

Individual

- -

70.9

72.5

Individual $\quad-\quad-64.4$

3.1
108
3.2
10.1
2.2
2.8

Fish

$\begin{array}{lr}\text { PL } & 2 \\ \text { PL } & 2 \\ \text { PL } & 4 \\ \text { PL } & 2 \\ \text { Nationwide } & -\end{array}$

\section{Individual}

Composite

Individual

Composite

Composite

\begin{tabular}{rr}
$\overline{195}$ & - \\
$\overline{164}$ & 125 \\
\hline
\end{tabular}

78.6

76.4

77.8

76.0

75.0

2.2

2.1

2.3

\section{Plants}

$\begin{array}{ll}\text { PL } & 2 \\ \text { PL } & 2 \\ \text { PL } & 2\end{array}$

Composite

Composite

Composite

$\begin{array}{ll}- & - \\ - & -\end{array}$

81.2

91.0

87.4

\section{Invertebrates}

$\begin{array}{ll}\text { PL } & 2 \\ \text { PL } & 2\end{array}$

Composite

Composite
84.4

78.7
2.3

2.9

1.5

3.1

3.2

2.2

2.8

\subsection{3
2.1
2.3
2.9}

\section{.4}

.6

.3

2.9

$* .5$

Four black-crowned night heron nesting attempts were monitored in pond L6. Fifty percent of these nests were successful.

\section{Observations of Waterbird Use of Leota Bottom}

Counts of waterfowl use at selected sites in Leota Bottom were conducted almost weekly in spring of 1989. The counts indicate trends, and a list of species observed is provided in table 18 . Factors including incubating birds and non-surveyed parts of the marshes were not considered. The largest number of ducks counted was 324, primarily green-winged teal (Anas arecca), in March. The smallest number was observed in May and consisted of 51 ducks, mostly gadwall. 
Table 25. Nesting success of selected waterbirds at Leota Bottom, Ouray National Wildlife Refuge, 1987-89

[Percent success: percentage of monitored nests known to hatch at least one egg, -, not applicable]

\begin{tabular}{lcc}
\hline \multicolumn{1}{c}{ Species } & $\begin{array}{c}\text { Monitored } \\
\text { nests }\end{array}$ & $\begin{array}{c}\text { Percent } \\
\text { success }\end{array}$ \\
\hline American coot & 24 & 54 \\
$\quad$ Pond L3 & 10 & 10 \\
Pond L5 & 36 & 72 \\
Pond L6 & 27 & 74 \\
Pond L7 & 24 & 83 \\
Pond L8 & 121 & - \\
Subtotal, American coot & - & 66 \\
Success for all American coot nests & 4 & 50 \\
Black-crowned night heron & 2 & 100 \\
Pied-billed grebe & 1 & 0 \\
Redhead & & \\
\hline
\end{tabular}

Broods of American coots and grebes were counted from dikes in Leota Bottom in June and July of 1987 and 1988 to supplement counts made by staff of Ouray NWR. The broods were not aged, so only the largest count was used. The total count of juvenile American coots increased from 56 in 1987 to 245 in 1988, and pied-billed grebes increased from 11 to 18 for the same period. The betweenyear difference was likely a reflection of the intensity of the survey effort. Personnel of Ouray NWR recorded 64, 56, and 22 broods of ducks for 1987, 1988, and 1989, respectively.

\section{Residue in Biota from Leota Bottom}

Tissue-residue data for biota from ponds in Leota Bottom were aggregated for analysis and interpretation. An examination of the data for individual samples indicated that only a few samples were substantially different. The selenium concentration in American coot eggs was used as the primary test criterion (table 26). Data for 26 eggs from ponds L3, L5, L6, L7, and L8 were treated as one unit. Selenium concentrations in eggs from these ponds had overlapping ranges and similar geometric means, and there were no significant differences in concentrations between ponds (KruskalWallis test).

A total of 39 randomly collected individual eggs and 14 non-randomly collected eggs were analyzed (table 27). Geometric mean selenium concentrations by bird species in the randomly collected eggs (where more than a single sample of a bird species was collected) ranged from a geometric mean of $1.8 \mu \mathrm{g} / \mathrm{g}$ to $7.3 \mu \mathrm{g} / \mathrm{g}$. Of the 53 eggs analyzed, the smallest selenium concentration $(1.2 \mu \mathrm{g} / \mathrm{g}) \mathrm{was}$ in a gadwall egg and a Canada goose egg, and the largest $(11.5 \mu \mathrm{g} / \mathrm{g})$ was in a black-crowned night heron egg (Peltz and Waddell, 1991, p. 123, 127, 139). No deformities were observed.

Selenium concentrations in non-random eggs were similar to random eggs. For gadwall, nonrandom eggs had a slightly larger geometric mean $(2.2 \mu \mathrm{g} / \mathrm{g})$ than randomly collected eggs $(1.8 \mu \mathrm{g} / \mathrm{g})$. For Canada geese and American coot, non-random eggs had a slightly smaller geometric mean (1.8 and $1.9 \mu \mathrm{g} / \mathrm{g}$ ) than random eggs $(2.1$ and $2.1 \mu \mathrm{g} / \mathrm{g})$, respectively. Concentration data from American coot eggs were tested using the Mann-Whitney test to determine if these were significantly different; they were not (ALS 0.28). Data from Canada geese and gadwall were not tested because of small sample size. 
Table 26. Geometric mean selenium concentrations of American coot eggs collected at several locations in Leota Bottom, Ouray National Wildlife Refuge

[Mean moisture content is an arithmetic mean. All concentrations in micrograms per gram (dry weight) can be expressed as wet weight by multiplying the dry-weight concentration by the factor ( 1 minus percentage of moisture content expressed as a decimal). Geometric means exclude values less than the analytical reporting limit]

\begin{tabular}{llcccc}
\hline Location & \multicolumn{1}{c}{$\begin{array}{c}\text { Sampling } \\
\text { scheme }\end{array}$} & $\begin{array}{c}\text { Sample } \\
\text { size }\end{array}$ & $\begin{array}{c}\text { Mean } \\
\text { moisture } \\
\text { content } \\
\text { (percent) }\end{array}$ & $\begin{array}{c}\text { Geometric } \\
\text { mean selenium } \\
\text { concentration } \\
(\mu \mathrm{g} / \mathrm{g})\end{array}$ & $\begin{array}{c}\text { Range } \\
(\mu \mathrm{gg} / \mathrm{g})\end{array}$ \\
\hline Leota 3 & Random & & 77.0 & 2.48 & $1.9-3.8$ \\
Leota 3 & Non-random & 3 & 75.1 & 2.12 & $1.5-3.0$ \\
Leota 5 & Non-random & 2 & 74.8 & 1.55 & $1.5-1.6$ \\
Leota 6 & Random & 4 & 76.0 & 2.05 & $1.9-2.2$ \\
Leota 7 & Random & 7 & 74.8 & 2.00 & $1.7-2.4$ \\
Leota 7 & Non-random & 1 & 72.1 & 1.60 & 1.6 \\
Leota 8 & Random & 6 & 68.7 & 2.06 & $1.3-2.5$ \\
Leota 8 & Non-random & 1 & 72.2 & 2.80 & 2.8 \\
All Leota & Random & 20 & 73.5 & 2.09 & $1.3-3.8$ \\
All Leota & Random + Non-random & 26 & 73.6 & 2.05 & $1.3-3.8$ \\
All Leota & Non-random & 6 & 74.0 & 1.91 & $1.5-3.0$ \\
\hline
\end{tabular}

Liver and muscle tissues from 1 Canada goose and 11 ducks were collected during the fall, simulating hunter take (table 27). Two additional samples of Canada goose liver were collected by hunters. Canada geese contained small-to-moderate selenium concentrations in their livers $(4.3 \mu \mathrm{g} / \mathrm{g}$, geometric mean for two individual livers and one composite sample of two livers) and breast muscle $(3.24 \mu \mathrm{g} / \mathrm{g}$, individual sample). Selenium concentrations (as dry weight) in duck livers ranged from $3.02 \mu \mathrm{g} / \mathrm{g}$ in a redhead to $11.9 \mu \mathrm{g} / \mathrm{g}$ in a gadwall (Peltz and Waddell, 1991, p. 139), with a geometric mean concentration of $5.0 \mu \mathrm{g} / \mathrm{g}$. Geometric mean selenium concentrations in muscle tissue from ducks ranged from $1.8 \mu \mathrm{g} / \mathrm{g}$ in redheads to $4.5 \mu \mathrm{g} / \mathrm{g}$ in gadwalls (table 27). The geometric mean selenium concentration for the 12 samples of muscle, expressed as fresh (wet) weight, was $0.6 \mu \mathrm{g} / \mathrm{g}$. Humans consuming these birds would need to consume $11.8 \mathrm{oz}$ of fresh muscle tissue to provide the recommended daily maximum limit of $200 \mu \mathrm{g}$ of selenium for adults (National Academy of Sciences, 1980).

Selenium concentrations in some species were statistically different. Selenium concentrations in liver and muscle from redheads were significantly less than concentrations in these tissues from gadwall for both liver and muscle (ALS 0.04). The redheads were believed to be of local origin (Richard Sjostrom, Ouray NWR, oral commun., 1989). Although gadwalls are common nesting birds on the refuge, the ones collected may have been raised locally or could have been transient. On the basis of the selenium concentrations, they appeared to have been feeding in different areas than the redheads or their food sources had different selenium concentrations. American coots collected during late summer had a geometric mean selenium concentration of $3.8 \mu \mathrm{g} / \mathrm{g}$ in their liver and $1.8 \mu \mathrm{g} / \mathrm{g}$ in muscle tissues. Although some of these birds may have been capable of flight, most were juvenile coots and all were believed to be local birds.

Two ruddy ducks were collected during spring migration in 1989 at pond L6 as soon as the species was observed at Ouray NWR. These ducks contained geometric mean selenium concentrations of $33.7 \mu \mathrm{g} / \mathrm{g}$ in liver and $10.2 \mu \mathrm{g} / \mathrm{g}$ in muscle tissue. Of particular interest was that eggs were in advanced development in the female, indicating that they could contain a considerable quantity of selenium acquired from another area. 
Table 27. Geometric mean selenium concentrations in several bird and fish samples collected from Leota Bottom at Ouray National Wildlife Refuge and in fish samples collected nationwide by the National Contaminant Biomonitoring Program

[NR, non-random sampling; R, random sampling, LV, liver; MS, muscle; mm, millimeter; g, gram; $\mu \mathrm{g} / \mathrm{g}$, micrograms per gram (dry weight); - , not specified. NCBP, National Contaminant Biomonitoring Program, from Schmitt and Brumbaugh, 1990 (1984 geometric mean concentration, 85th percentile, converted to dry weight using 75 percent moisture). Weight of bird egg is mean weight of contents. Mean length, weight, and moisture content are arithmetic means]

\begin{tabular}{|c|c|c|c|c|c|c|}
\hline Species & $\begin{array}{c}\text { Sample } \\
\text { size }\end{array}$ & $\begin{array}{c}\text { Sample } \\
\text { type }\end{array}$ & $\begin{array}{l}\text { Mean } \\
\text { length } \\
(\mathrm{mm})\end{array}$ & $\begin{array}{l}\text { Mean } \\
\text { weight } \\
\text { (g) }\end{array}$ & $\begin{array}{l}\text { Mean } \\
\text { moisture } \\
\text { content } \\
\text { (percent) }\end{array}$ & $\begin{array}{c}\text { Geometric } \\
\text { mean selenium } \\
\text { concentration } \\
(\mu \mathrm{g} / \mathrm{g})\end{array}$ \\
\hline
\end{tabular}

American coot

American coot (NR)

Black-crowned night heron

Canada goose

Canada goose (NR)

Cinnamon teal

Gadwall

Gadwall (NR)

Mallard

Pied-billed grebe

Redhead

American coot (LV)

American coot (MS)

Canada goose (LV)

Canada goose (MS), Fall

Cinnamon teal (LV), Fall

Cinnamon teal (MS), Fall

Gadwall (LV), Fall

Gadwall (MS), Fall

Mallard (LV), Fall

Mallard (MS), Fall

Redhead (LV), Fall

Redhead (MS), Fall

Ruddy duck (LV), Spring

Ruddy duck (LV), Fall

Ruddy duck (MS), Spring

Ruddy duck (MS), Fall

$\begin{aligned} 20 & \text { Individual } \\ 6 & \text { Individual } \\ 3 & \text { Individual } \\ 4 & \text { Individual } \\ 4 & \text { Individual } \\ 4 & \text { Individual } \\ 2 & \text { Individual } \\ 4 & \text { Individual } \\ 3 & \text { Individual } \\ 2 & \text { Individual } \\ 1 & \text { Individual }\end{aligned}$

\section{Bird eggs}

Individual

\section{Bird tissue}

$\begin{aligned} 12 & \text { Individual } \\ 7 & \text { Individual } \\ 3 & \text { Composite, Individual } \\ 1 & \text { Individual } \\ 1 & \text { Individual } \\ 1 & \text { Individual } \\ 3 & \text { Individual } \\ 3 & \text { Individual } \\ 1 & \text { Individual } \\ 1 & \text { Individual } \\ 5 & \text { Individual } \\ 5 & \text { Individual } \\ 2 & \text { Individual } \\ 1 & \text { Individual } \\ 2 & \text { Individual } \\ 1 & \text { Individual }\end{aligned}$

$\begin{array}{lll}- & - & 73.1 \\ - & - & 72.6 \\ - & - & 71.4 \\ - & - & 73.5 \\ - & - & 68.5 \\ - & - & 74.8 \\ - & - & 74.7 \\ - & - & 75.0 \\ - & - & 70.2 \\ - & - & 72.6 \\ - & - & 73.3 \\ - & - & 76.6 \\ - & - & 71.9 \\ - & - & 72.1 \\ - & - & 72.5 \\ - & - & 80.8\end{array}$

73.1

73.5

74.0

81.0

68.4

59.0

67.6

68.1

64.5

70.3

77.1

68.0

Fish
10.2

$\begin{aligned} 10 & \text { Composite } \\ 7 & \text { Composite } \\ 3 & \text { Composite, Individual } \\ - & \text { Composite }\end{aligned}$

203

348

143

$\begin{array}{rr}164 & 81.5 \\ 755 & 75.5 \\ 65 & 76.6 \\ - & 75.0\end{array}$

75.0

Black bullhead

Green sunfish

Fish, NCBP nationwide

-


Selenium concentrations in individual fish samples for Leota Bottom ponds L3 and L6 ranged from 0.58 to $5 \mu \mathrm{g} / \mathrm{g}$ (Peltz and Waddell, 1991, p. 123, 127), with a geometric mean of $2.3 \mu \mathrm{g} / \mathrm{g}$. This is less than the 85 th percentile for concentrations of selenium in fish nationwide. Green sunfish (Lepomis cyanellus) had the largest geometric mean selenium concentration, $3.9 \mu \mathrm{g} / \mathrm{g}$, followed by carp and black bullhead (table 27). Concentrations of other elements were not unusually large.

Plant samples were taken at ponds L3, L6, and L8 and in the water-supply canal between ponds L5 and L6. Selenium concentrations were small in all samples and did not exceed $1.4 \mu \mathrm{g} / \mathrm{g}$ in cattail and $1.2 \mu \mathrm{g} / \mathrm{g}$ in other rooted non-emergent plants (Peltz and Waddell, 1991, p. 123, 131). Geometric mean concentrations of selenium are shown in table 28 for each of the taxa for all areas combined.

The selenium concentrations in invertebrates ranged from $0.66 \mu \mathrm{g} / \mathrm{g}$ (snails) to $3.7 \mu \mathrm{g} / \mathrm{g}$ (unseparated contents, mostly chironomids taken from the stomachs of black bullheads)(Peltz and Waddell, 1991, p. 127). The mixed invertebrate samples had a geometric mean selenium concentration of $2.9 \mu \mathrm{g} / \mathrm{g}$ (table 28). These concentrations are less than levels known to be hazardous to biota feeding on them.

Aluminum concentrations were $20,000 \mu \mathrm{g} / \mathrm{g}$ and iron concentrations were $15,500 \mu \mathrm{g} / \mathrm{g}$ in the single sample of chironomid larvae salvaged from black bullhead stomachs in 1988 . These concentrations were substantially larger than concentrations in a similar sample salvaged in 1989. Small quantities of vegetation or other invertebrates may have been included as part of the composite,

Table 28. Geometric mean selenium concentrations in composite samples of plants and invertebrates collected from Leota Bottom at Ouray National Wildlife Refuge

[ $\mu \mathrm{g} / \mathrm{g}$, micrograms per gram (dry weight). Mean moisture content is an arithmetic mean]

\begin{tabular}{lccc}
\hline \multicolumn{1}{c}{ Species } & $\begin{array}{c}\text { Sample } \\
\text { size }\end{array}$ & $\begin{array}{c}\text { Mean } \\
\text { moisture } \\
\text { content } \\
\text { (percent) }\end{array}$ & $\begin{array}{c}\text { Geometric } \\
\text { mean selenium } \\
\text { concentration } \\
(\mu \mathrm{g} / \mathrm{g})\end{array}$ \\
\hline & & Plants & \\
Chara & 4 & 79.8 & 0.1 \\
Filamentous green algae & 6 & 83.8 & .9 \\
Water milfoil & 1 & 88.6 & 1.2 \\
Polygomum & 1 & 95.7 & .84 \\
Potamogeton & 8 & 90.5 & .9 \\
Hardstem bulrush (seed) & 1 & 15.2 & .12 \\
Cattail & 8 & 88.0 & .5 \\
Cattail (seed) & 1 & 55.5 & $<.22$ \\
& & Invertebrates & 3.4 \\
Anisoptera & 1 & 88.3 & 3.1 \\
Chironomidae & 2 & 71.7 & 1.8 \\
Hemiptera & 1 & 83.7 & 2.9 \\
Mixed & 2 & 86.1 & .66 \\
Snails & 1 & 69.5 & 2.4 \\
Zygoptera & 1 & 83.6 & \\
& & & \\
\hline
\end{tabular}


possibly biasing the inorganic concentrations. Samples of vegetation, invertebrates, and sediment in the data base were compared to determine if contamination could have occurred. Other samples of vegetation did not contain large concentrations of aluminum or iron that would account for these data. Sediment did, however, contain large quantities of aluminum and iron, and other samples of chironomids removed from bullheads during the same sampling period at other collection sites had large concentrations of these elements.

\section{Nesting Observations in Sheppard Bottom at Ouray National Wildlife Refuge}

A total of 59 American coot nests were monitored in Sheppard Bottom at ponds S2, S3, S4, and S5 (table 29). Overall, about 46 percent of American coot nests were successful in hatching at least one egg, but success varied between ponds ranging from 36 percent at pond S3 to 100 percent at pond S2. Predation was the largest cause of nesting failure (49 percent). Data are believed to be representative of all ponds except pond S2, where searches were primarily along the borrow area for the dike. Predation reduced calculated nest success at pond S5 because many of the nests occurred near borrow ditches, which were apparently vulnerable nest sites. Reduced nesting success was not found at pond S2, however, where most nests monitored were on the marsh side of the borrow area.

Eleven pied-billed grebe nests were monitored in three ponds (table 29). Overall they had an estimated 55 percent success of hatching at least one egg. The successful nests were found only in pond S5. Three nests in S3 and S4 were lost to predation. Only 30 percent of 10 western grebe nests monitored in pond S3 were successful. One of three nests of black-crowned night herons monitored in pond S3 was successful.

Only two American coot eggs from two different nests failed to hatch, due to unknown causes. These were in nests that successfully hatched at least one egg ( 7 percent of successful nests). No deformed American coot embryos were observed in eggs collected from nests in Sheppard Bottom ponds $\mathrm{S} 2, \mathrm{~S} 3, \mathrm{~S} 4$, and S5.

Table 29. Nesting success of selected waterbirds at Sheppard Bottom, Ouray National Wildlife Refuge, 1987-89

[Percent success: percentage of monitored nests known to hatch at least one egg; -, not applicable]

\begin{tabular}{lcc}
\hline Species & $\begin{array}{c}\text { Monitored } \\
\text { nests }\end{array}$ & $\begin{array}{c}\text { Percent } \\
\text { success }\end{array}$ \\
\hline
\end{tabular}

American coot

Pond S2

Pond S3

Pond S5

Total, American coot

Success, American coot nests

Black-crowned night heron

Pied-billed grebe 
Canada goose nesting platforms were searched for unhatched eggs between 1987 and 1989 . One deformed embryo was found in these eggs. Upon collection, the embryo was found dead, fully developed except for severely reduced or absent eyes, and with a shortened lower bill. The occurrence of deformed goose embryo appears unusual. For example, Hanson and Eberhardt (1971) studied 1,675 Canada goose eggs that failed to hatch near the Hanford nuclear reactor complex in Washington and found no incidence of deformed embryos (W.C. Hanson, oral commun., 1991). Unhatched eggs were commonly found in the nests. Many had immature to well developed embryos; however, many were badly decomposed and it was difficult to determine the stage of development. In 1988, 11 nesting platforms were monitored for unhatched eggs. Seven nests were successful; however three of these nests (43 percent) had unhatched eggs. Two of the abandoned nests, or 50 percent, had developed embryos. Because incubation was not monitored, it was not possible to determine if these nests were abandoned solely because the eggs failed to develop properly and hatch, or were abandoned for causes unrelated to egg health.

\section{Observations of Waterbird Use of Sheppard Bottom}

Observations at Sheppard Bottom were made at ponds S3 and S5 in 1988 and 1989 (table 9). Counts in this area were usually made three to five times a month during the nesting and broodrearing season. Fall counts were reduced because of the lack of water, and both ponds were temporarily drained in late summer to control fish and repair dikes, precluding and reducing waterfowl use. Counts of ducks were largest in mid-March and early April immediately after ponds in Sheppard Bottom thawed. The smallest number of ducks were observed in July and August as water levels declined, particularly in pond S5. Use of these ponds by American coots was largest at S3 during summer when water was low in pond S5.

Counts of juvenile American coots and grebes were conducted from dikes in Sheppard Bottom in June and July of 1987 and 1988 to supplement waterfowl counts made by staff of Ouray NWR. The ages of the broods were not determined; therefore, only the largest count of total juvenile American coots and grebes were used. Observed American coot production totaled 25 and 60 birds for 1987 and 1988, respectively, while 3 and 5 young grebes were observed each year. Refuge staff counted 19, 31, and 22 total duck broods per year during 1987, 1988, and 1989. Low water levels in ponds S3 and S5 by late June 1989 undoubtedly reduced production or altered distribution of juvenile birds.

\section{Residue in Biota from Sheppard Bottom}

Data for the ponds in Sheppard Bottom are discussed by individual pond because examination of the data for individual samples indicated that substantial differences existed in concentrations of residues. Selenium concentrations in randomly selected American coot eggs were used as the primary criterion for aggregation of the data. Concentrations increased from pond S3 to S4 to S5, and geometric means for these sites were 3.5, 4.7, and $6.4 \mu \mathrm{g} / \mathrm{g}$, respectively (fig. 49). The largest individual concentrations were $4.6,6.5$, and $18.9 \mu \mathrm{g} / \mathrm{g}$ for samples from these ponds, respectively (Peltz and Waddell, 1991, p. 147, 143, 155). Only two egg samples of American coots exceeded $15 \mu \mathrm{g} / \mathrm{g}$; these consisted of a random egg with $18.4 \mu \mathrm{g} / \mathrm{g}$ and a non-random egg with $18.9 \mu \mathrm{g} / \mathrm{g}$ from Sheppard Bottom pond S5. Studies by Heinz and others (1987), as reported by Lemly and Smith (1987), indicated that with captive-reared mallards, a selenium concentration of about $15 \mu \mathrm{g} / \mathrm{g}$ was associated with some degree of reproductive impairment. The mean selenium concentration in American coot eggs at pond S5 approaches (and is exceeded in pied-billed grebes and black-crowned night herons) the mean concentration of $8 \mu \mathrm{g} / \mathrm{g}$ associated with impaired hatchability in populations of some species (Skorupa and Ohlendorf, 1991).

A limited effort was made to obtain biological tissue at pond S1; five eggs were obtained. Selenium concentrations ranged from 0.93 to $3.5 \mu \mathrm{g} / \mathrm{g}$. The largest concentration was from a nonrandom cinnamon teal egg. One northern shoveler was collected during spring migration in March to determine concentrations of inorganic elements in birds migrating through or returning to Ouray 
NWR. The northern shoveler had a selenium concentration of $8.7 \mu \mathrm{g} / \mathrm{g}$ in the liver and $2.1 \mu \mathrm{g} / \mathrm{g}$ in muscle (table 30) and mercury concentrations of $11.3 \mu \mathrm{g} / \mathrm{g}$ and $3.23 \mu \mathrm{g} / \mathrm{g}$. One great blue heron was found dead at S1 and was necropsied by the National Wildlife Health Laboratory. The dry weight selenium concentration in the liver of this bird was $11 \mu \mathrm{g} / \mathrm{g}$ (table 30), and the mercury concentration in the liver was $18.9 \mu \mathrm{g} / \mathrm{g}(4.3 \mu \mathrm{g} / \mathrm{g}$ wet weight). The kidney contained $1.27 \mu \mathrm{g} / \mathrm{g}$ wet weight mercury. The National Wildlife Health Laboratory concluded that the mercury concentration was within the normal range for this species and that the bird likely died of selenium poisoning.

American coots were observed in Sheppard Bottom during spring migration in March 1988 and were believed to be in unhealthy condition, as three birds were caught by hand at pond S1. The coots were necropsied, but only one of the three had a less-than-normal muscle mass, and no disease or other condition was observed during the necropsy that would explain the vulnerability of this bird to capture. The selenium concentrations in the livers of these birds ranged from 2.2 to $3.6 \mu \mathrm{g} / \mathrm{g}$ wet weight (National Wildlife Health Laboratory, written commun., 1991). Three American coot livers were simultaneously salvaged from predator kills at three different sites in Sheppard Bottom. Selenium concentrations ranged from 1.1 to $2.3 \mu \mathrm{g} / \mathrm{g}$ wet weight and were not significantly different from concentrations found in the three birds found at S1. The largest dry weight selenium concentration (using 70-percent moisture content) was $12 \mu \mathrm{g} / \mathrm{g}$ for these American coots. On the basis of this small sample, American coots migrating to or through Ouray NWR had small to moderate selenium concentrations.

A total of 12 eggs were collected in pond S2 and in the immediate vicinity. Selenium concentrations in these eggs ranged from 0.98 to $3.35 \mu \mathrm{g} / \mathrm{g}$ dry weight (Peltz and Waddell, 1991, p. 143). Ten of these eggs were Canada goose eggs. The largest selenium concentration was from a random Canada goose egg, and the smallest selenium concentration was from a non-random Canada goose egg.

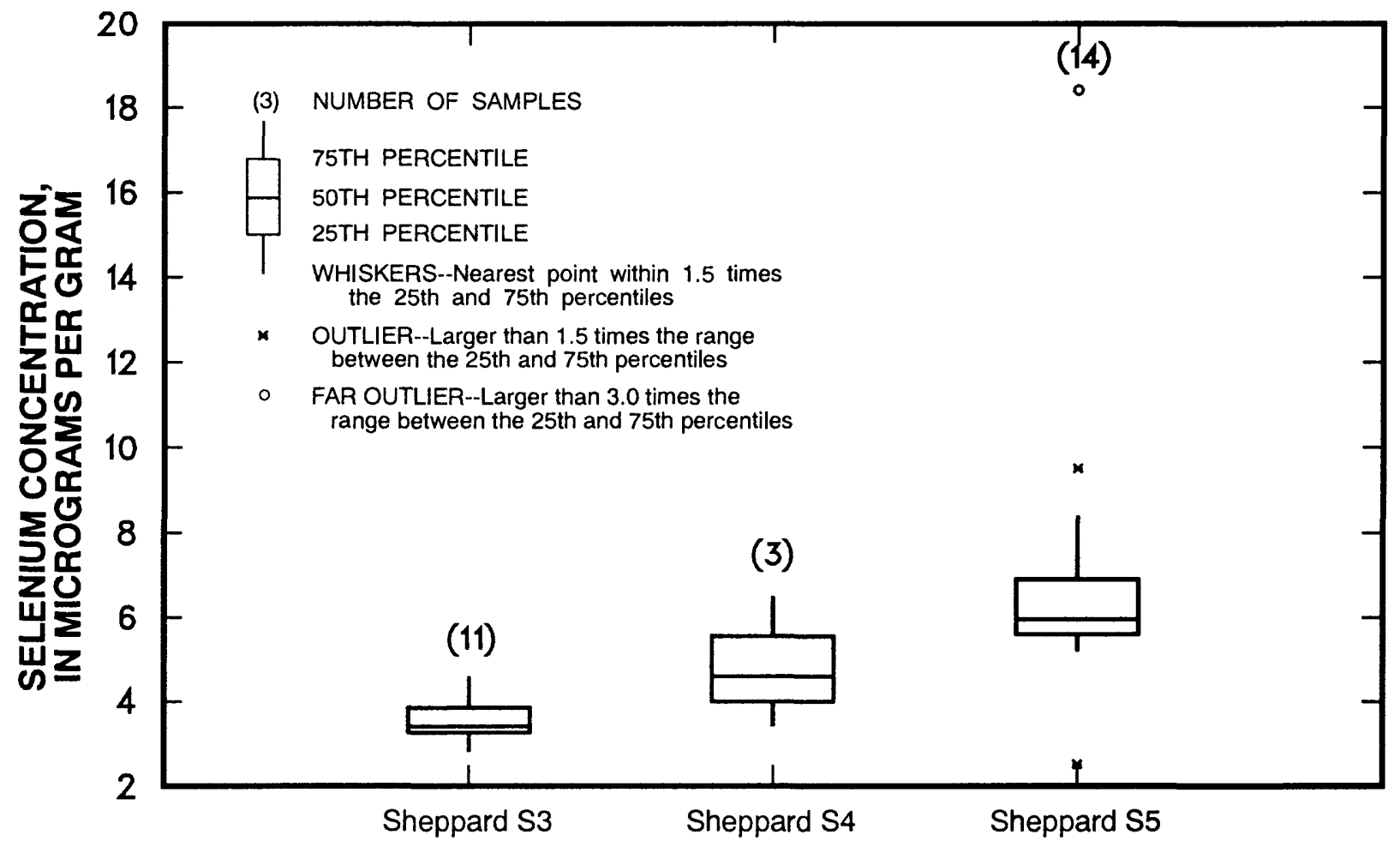

Figure 49. Selenium concentrations in American coot eggs from three ponds in Sheppard Bottom at Ouray National Wildlife Refuge. 
Combined data for ponds S1 and S2 for Canada geese (table 30) indicate that nine non-random eggs had significantly (ALS 0.05) smaller concentrations than two random eggs, with geometric mean selenium concentrations of 1.4 and $2.8 \mu \mathrm{g} / \mathrm{g}$, respectively.

Selenium concentrations in 31 eggs collected in and near pond S3 ranged from 0.99 to $6.8 \mu \mathrm{g} / \mathrm{g}$ (Peltz and Waddell, 1991, p. 147). The largest concentration was in a pied-billed grebe egg. The geometric mean selenium concentration in randomly collected American coot eggs was $3.5 \mu \mathrm{g} / \mathrm{g}$ (table 30). Five gadwall eggs were collected at random in the vicinity of pond S3. These eggs had a geometric mean concentration of $2.1 \mu \mathrm{g} / \mathrm{g}$. The geometric mean selenium concentration in both random and nonrandom Canada goose eggs was $1.7 \mu \mathrm{g} / \mathrm{g}$. When data for 4 randomly collected and 20 non-randomly collected Canada goose eggs for S1, S2, and S3 were compared, selenium concentrations were similar.

Table 30. Geometric mean selenium concentrations in bird egg and bird tissue samples collected from Sheppard Bottom ponds S1, S2, S3, and S4 at Ouray National Wildlife Refuge

[All egg samples are random except those that are indicated by NR, non-random sample; LV, liver; MS, muscle; mm, millimeter; g, gram; $\mu \mathrm{g} / \mathrm{g}$, micrograms per gram; -, not specified; SB, Sheppard Bottom; S1-S4, ponds 1-4; weight of bird egg is mean weight of contents. Mean length, weight, and moisture content are arithmetic means]

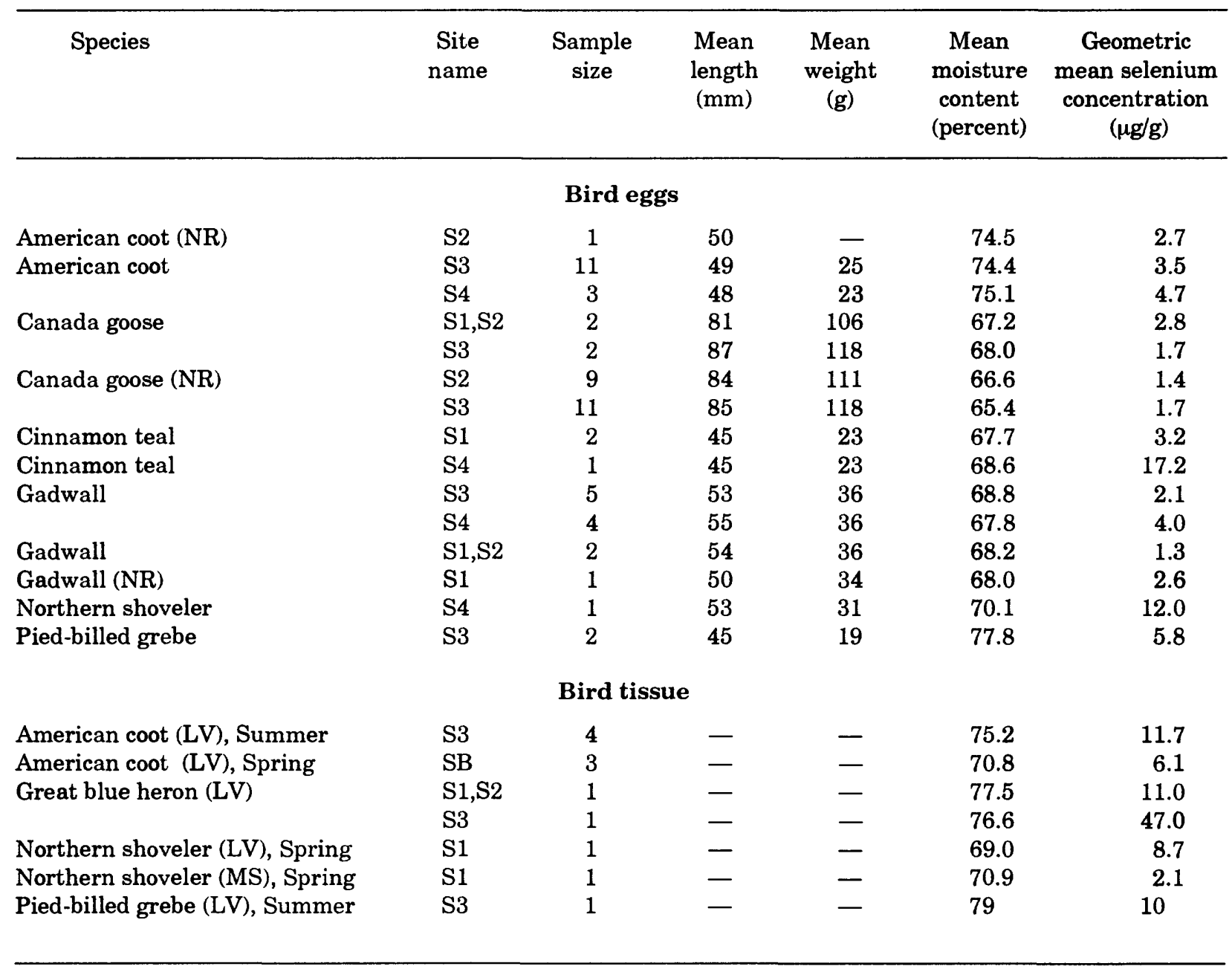


Seven eggs were collected in the vicinity of pond S4. Three American coot and 4 gadwall eggs had geometric mean selenium concentrations of $4.7 \mu \mathrm{g} / \mathrm{g}$ and $4.0 \mu \mathrm{g} / \mathrm{g}$, respectively (table 30). Eggs from cinnamon teal and northern shoveler nests had individual concentrations of 17.2 and $12.0 \mu \mathrm{g} / \mathrm{g}$, respectively. These two eggs exceed the $10 \mu \mathrm{g} / \mathrm{g}$ threshold associated with reduced reproductive success in some species (Skorupa and Ohlendorf, 1991).

A total of 34 egg samples obtained from and near pond S5 (adjacent to the South Roadside Pond) were analyzed. Geometric mean selenium concentrations ranged from 1.4 to $10.6 \mu \mathrm{g} / \mathrm{g}$ (table 31 ). Selenium concentrations of $10 \mu \mathrm{g} / \mathrm{g}$ were exceeded in six eggs (Peltz and Waddell, 1991, p. 155). Selenium concentrations in American coot eggs ranged from 2.5 to $18.9 \mu \mathrm{g} / \mathrm{g}$. Randomly collected American coot eggs had a geometric mean selenium concentration of $6.4 \mu \mathrm{g} / \mathrm{g}$ (table 31 ). Two nonrandomly collected American coot eggs had a geometric mean selenium concentration of $10.6 \mu \mathrm{g} / \mathrm{g}$. The largest geometric mean concentration for randomly collected eggs was in black-crowned night heron eggs $(9.6 \mu \mathrm{g} / \mathrm{g})$ followed by pied-billed grebe eggs $(8.6 \mu \mathrm{g} / \mathrm{g})$. Both species have concentrations that exceed the $10 \mu \mathrm{g} / \mathrm{g}$ threshold associated with reduced reproductive success in some species (Skorupa and Ohlendorf, 1991).

\section{Table 31. Geometric mean selenium concentrations in bird egg and bird tissue samples collected from} pond S5 in Sheppard Bottom at Ouray National Wildlife Refuge

[All egg samples are random except those that are indicated by NR, non-random sample; LV, liver; MS, muscle; mm, millimeter; g, gram; $\mu \mathrm{g} / \mathrm{g}$, micrograms per gram (dry weight); - , not specified; *, single real value. Weight of bird egg is mean weight of contents. Mean length, weight, and moisture content are arithmetic means]

\begin{tabular}{ccccccc}
\hline Species & $\begin{array}{c}\text { Sample } \\
\text { size }\end{array}$ & $\begin{array}{c}\text { Sample } \\
\text { type }\end{array}$ & $\begin{array}{c}\text { Mean } \\
\text { length } \\
(\mathrm{mm})\end{array}$ & $\begin{array}{c}\text { Mean } \\
\text { weight } \\
(\mathrm{g})\end{array}$ & $\begin{array}{c}\text { Mean } \\
\text { moisture } \\
\text { content } \\
\text { (percent) }\end{array}$ & $\begin{array}{c}\text { Geometric } \\
\text { mean selenium } \\
\text { concentration } \\
(\mu \mathrm{g} / \mathrm{g})\end{array}$ \\
\hline
\end{tabular}

\section{Bird eggs}

American avocet

American coot

American coot (NR)

Black-crowned night heron

Black-necked stilt

Canada goose

Canada goose (NR)

Cinnamon teal

Pied-billed grebe

Yellow-headed blackbird

American coot (LV)

American coot (MS)

Mallard (LV)

Mallard (MS)

Scaup (LV)

Mallard crop
1 Individual

14 Individual

2 Individual

4 Individual

2 Individual

1 Individual

2 Individual

1 Individual

6 Individual

1 Composite

\section{Bird tissue}

6 Individual

1 Individual

2 Individual

2 Individual

1 Individual

2 Individual

\section{0}

49

45

50

41

85

85

44

43

27

24
25
-
30
17
123
-
24
17

72.9

3.6

73.7

6.4

73.7

10.6

79.9

9.6

73.9

5.4

69.8

1.4

64.6

1.7

70.9

3.1

76.3

8.6

83.1

5.1

73.1

10.6

74.5

6.3

70.9

7.8

71.1

3.6

71.6

18 
At American coot nests with successful hatching in Sheppard Bottom, two nests had single unhatched eggs. One of these was from pond S2, and the other was from pond S5. The egg from pond S2 was well developed and had a selenium concentration of only $2.7 \mu \mathrm{g} / \mathrm{g}$. The egg from pond S5 had a selenium concentration of $18.9 \mu \mathrm{g} / \mathrm{g}$, the contents were rotten, and the embryo died at an early stage of incubation. At another nest in pond S5, however, all eggs hatched from a nest in which the randomly collected egg had a live embryo with a selenium concentration of $18.4 \mu \mathrm{g} / \mathrm{g}$.

American coots were sampled at pond S3 during the summer to assess selenium concentration in tissue during the brood-rearing season. The livers had a geometric mean selenium concentration of $11.7 \mu \mathrm{g} / \mathrm{g}$ (table 30). Because of the juxtaposition of all the ponds in Sheppard Bottom, it is possible that these birds may have been moving between ponds. Livers of juvenile American coots from pond S5 had a geometric mean concentration of $10.6 \mu \mathrm{g} / \mathrm{g}$ selenium (table 31 ), very similar to the concentration of $11.7 \mu \mathrm{g} / \mathrm{g}$ found in coots from pond S3. One immature pied-billed grebe was killed in gill nets in July at pond S3. The grebe had a selenium concentration of $10 \mu \mathrm{g} / \mathrm{g}$ in its liver (Peltz and Waddell, 1991, p. 146).

The largest selenium concentration in non-egg bird tissues at S5 was $18.8 \mu \mathrm{g} / \mathrm{g}$ in the liver of an American coot, followed by $18 \mu \mathrm{g} / \mathrm{g}$ in the liver of an adult female scaup (Aytha sp.) killed in a gill net during spring migration in April. Two mallards collected in November had geometric mean selenium concentrations of 7.8 and $3.6 \mu \mathrm{g} / \mathrm{g}$ in the liver and muscle tissues, respectively (table 31 ).

One great blue heron was found dead at pond S3 and was necropsied by the National Wildlife Health Laboratory. The selenium concentration in the liver of this bird was $47 \mu \mathrm{g} / \mathrm{g}$, and the mercury concentration in its liver was $24 \mu \mathrm{g} / \mathrm{g}(5.6 \mu \mathrm{g} / \mathrm{g}$, wet weight)(Peltz and Waddell, 1991, p. 146, 147). The laboratory concluded that the mercury concentration was less than the range expected to have a direct role in the death of this heron and that the bird likely died of selenium poisoning.

As indicated in the section on nesting observations, a Canada goose embryo was found with deformities typically associated with large selenium concentrations. The selenium concentration in the goose embryo was small $(2.5 \mu \mathrm{g} / \mathrm{g}$ dry weight).

Residue of selenium in tissue samples of fish from pond S3 ranged from 2.5 to $13.9 \mu \mathrm{g} / \mathrm{g}$ (Peltz and Waddell, 1991, p. 147, 151). Common carp $(5.5 \mu \mathrm{g} / \mathrm{g})$ had the largest geometric mean selenium concentration (table 32$)$, followed by green sunfish $(5.4 \mu \mathrm{g} / \mathrm{g})$ and black bullhead $(3.9 \mu \mathrm{g} / \mathrm{g})$. Black bullhead had both the largest and smallest selenium concentrations of the species collected. Geometric mean concentrations of selenium in fish from Sheppard Bottom were 1 to 3 times larger than the geometric mean of $2.9 \mu \mathrm{g} / \mathrm{g}$ reported for fish nationwide. The largest mercury concentration observed was $0.306 \mu \mathrm{g} / \mathrm{g}$ in a sample of black bullheads. Concentrations of other elements appeared normal.

Residue of selenium in selected samples of fish tissue for pond S5 ranged from 4.8 to $19.9 \mu \mathrm{g} / \mathrm{g}$ (Peltz and Waddell, 1991, p. 159). Common carp had the largest geometric mean selenium concentration $(9.2 \mu \mathrm{g} / \mathrm{g})$, followed by black bullhead $(6.8 \mu \mathrm{g} / \mathrm{g})$ and green sunfish $(5.1 \mu \mathrm{g} / \mathrm{g})($ table 32$)$.

Ten plant samples were collected at pond S3 and 10 at pond S5. Selenium concentrations were small at pond S3, ranging from $1.7 \mu \mathrm{g} / \mathrm{g}$ in Potamogeton nodosus to $0.30 \mu \mathrm{g} / \mathrm{g}$ in cattail. Selenium concentrations at pond S5 were slightly larger, ranging from $6.3 \mu \mathrm{g} / \mathrm{g}$ in filamentous green algae to $0.55 \mu \mathrm{g} / \mathrm{g}$ in cattail (Peltz and Waddell, 1991, p. 159).

Selenium concentrations in samples of invertebrates at pond S3 ranged from $3 \mu \mathrm{g} / \mathrm{g}$ in hemiptera to $5.4 \mu \mathrm{g} / \mathrm{g}$ in a bulk sample, primarily chironomids taken from the stomachs of black bullheads (Peltz and Waddell, 1991, p. 151). Combining all invertebrate samples from pond S3 resulted in a geometric mean concentration of $3.8 \mu \mathrm{g} / \mathrm{g}$ selenium.

Selenium concentrations in samples of invertebrates at pond S5 ranged from $4.4 \mu \mathrm{g} / \mathrm{g}$ in odonates to $33 \mu \mathrm{g} / \mathrm{g}$ in chironomid samples taken from black bullheads (Peltz and Waddell, 1991, p. 
Table 32. Geometric mean selenium concentrations in composite samples of whole-body fish, plants, and invertebrates collected from ponds S3 and S5 in Sheppard Bottom at Ouray National Wildlife Refuge and in fish samples collected nationwide by the National Contaminant Biomonitoring Program

[S3, Sheppard Bottom pond 3; S5, Sheppard Bottom pond 5; mm, millimeter; g, gram; $\mu \mathrm{g} / \mathrm{g}$, micrograms per gram (dry weight); - , not specified; NCBP, National Contaminant Biomonitoring Program, from Schmitt and Brumbaugh, 1990 (1984 geometric mean concentration, 85th percentile, converted to dry weight using 75 percent moisture). Mean length, weight, and moisture content are arithmetic means]

\begin{tabular}{cccccc}
\hline Species & Site & Sample & Mean \\
name & size & $\begin{array}{c}\text { Mean } \\
\text { length } \\
(\mathrm{mm})\end{array}$ & $\begin{array}{c}\text { weight } \\
(\mathrm{g})\end{array}$ & $\begin{array}{c}\text { Mean } \\
\text { moisture } \\
\text { content } \\
(\text { percent })\end{array}$ & $\begin{array}{c}\text { Geometric } \\
\text { concentration selenium } \\
(\mu \mathrm{g} / \mathrm{g})\end{array}$ \\
\hline
\end{tabular}

Black bullhead

Common carp

Green sunfish

Black bullhead

Common carp

Green sunfish

Fish, NCBP nationwide

Blue-green algae

Filamentous green algae

Najas marina

Potamogeton

Cattail

Blue-green algae

Filamentous green algae

Najas marina

Potamogeton

Cattail

Hardstem bulrush (seed)

Invertebrates, mixed

Hemiptera

Odonata

Chironomidae

Invertebrates, mixed

Hemiptera

Odonata

Chironomidae
Fish
S3

S3

S3

S5

S5

S5

$\begin{array}{ll}6 & 218 \\ 7 & 359 \\ 2 & 137 \\ 4 & 185 \\ 5 & 278 \\ 1 & 105\end{array}$

177

815

51

96

94

20

-

$-$

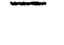

Plants
S3

S3

S3

S3

S3

S5

S5

S5

S5

S5

S5
1

1

1

4

3

1

2

1

2

3

1
80.7

76.6

78.7

82.0

78.2

76.3

75.0

2.9

3.9

5.5

5.4

6.8

9.2

5.1
74.2

69.7

92.7

88.5

88.0

82.6

83.7

93.7

89.4

87.1

13.8
1.3

.99

1.6

1.3

.6

5.7

3.8

3.3

2.4

1.8

2.1

\section{Invertebrates}

S3

S3

S3

S3

S5

S5

S5

S5

$\begin{array}{lll}2 & - & - \\ 2 & - & - \\ 1 & - & - \\ 1 & - & - \\ 2 & - & - \\ 2 & - & - \\ 1 & - & -\end{array}$

90.3

3.4

79.3

3.4

80.8

4.2

86.7

5.4

91.8

6.9

82.3

7.2

84.2

89.5 
159). The geometric mean selenium concentration for all invertebrate samples at pond S5 was $8.4 \mu \mathrm{g} / \mathrm{g}$. Concentrations are large enough to be in the range known to cause reproductive problems in waterfowl.

Selenium concentrations in common carp and black bullhead were 68 and 72 percent larger in pond S5 than in pond S3. Concentrations in plants and invertebrates were also larger in pond S5 than pond S3.

\section{Nesting Observations at the Roadside Ponds at Ouray National Wildlife Refuge}

Nesting studies were completed in 1987, 1988, and 1989. The primary emphasis was on American coot and pied-billed grebe in 1987 and was expanded to all waterbirds using the ponds in 1988.

A total of 12 American coot nests were monitored in and near the North Roadside Pond. Overall, 17 percent of the nests were successful in hatching at least one egg (table 33). No nests were completely successful in hatching all eggs. Of 10 nests that were not preyed upon, each had at least 1 egg that failed to hatch, and 8 of these 10 nests were complete failures. Deformed embryos were observed in 2 of the 10 nests followed to completion that were not depredated.

A total of 15 American coot nesting attempts were monitored in and near the South Roadside Pond. One nest ( 7 percent) was completely successful, apparently hatching all eggs. All other nests failed to hatch even a single egg. A total of four nests were known to be lost to predators or flooding (27 percent). Only a few developed embryos were found in eggs that were examined, suggesting high mortality of the embryos at very early stages of incubation. No deformed American coot embryos were observed at the South Roadside Pond.

Only 11 percent (3 nests) of 27 nests monitored with known outcome at the North and South Roadside Ponds successfully hatched at least 1 egg. All eggs hatched in only one nest and a randomly collected egg from the nest contained $4.1 \mu \mathrm{g} / \mathrm{g}$ selenium. Excluding predation or other explainable losses, 18 of 21 nests were total failures; eggs failed to develop and hatch or developed into deformed embryos.

Three pied-billed grebe nesting attempts were monitored, all on the North Roadside Pond. Two nests were successful (67 percent), and one nest was depredated. Both successful nests also had dead embryos, but no gross deformities were noted. At one of these nests, a hatchling and an adult grebe were found dead but were too decomposed for necropsy.

Four gadwall nests were monitored near the Roadside Ponds. Two of these were successful in hatching at least one egg, one nest was depredated, and one was abandoned. Three of the four nests had dead embryos, including the nest abandoned while still being incubated. It is unknown whether the depredated nest would have had dead embryos, but the random egg that was collected had just begun incubating and appeared normal. Two eggs collected from this nest were incubated and both eggs failed to hatch, suggesting that all four nests would have had dead embryos. One egg was about 75 percent developed, the other had slight development. The developed embryo appeared normal (Charles Henny, U.S. Fish and Wildlife Service, written commun., 1988).

Three mallard nests near the Roadside Ponds were monitored, and none were successful. Two of the nests were abandoned, and all eggs in the third nest failed to hatch. Well-developed but deformed embryos were present in the nest that failed to hatch. One cinnamon teal nest was monitored and was fully successful in hatching eggs. The random egg from this nest contained a selenium concentration of $7.9 \mu \mathrm{g} / \mathrm{g}$. One redhead nest was also monitored but failed to hatch any eggs. All eggs in this nest contained dead or deformed embryos. A randomly collected egg from the redhead nest contained $19.7 \mu \mathrm{g} / \mathrm{g}$ selenium. 
Table 33. Nesting success of selected waterbirds at the Roadside Ponds, Ouray National Wildlife Refuge, 1987-89

[Percent success: percentage of monitored nests known to hatch at least one egg; - , not applicable]

\begin{tabular}{lcc}
\hline \multicolumn{1}{c}{ Species } & $\begin{array}{c}\text { Monitored } \\
\text { nests }\end{array}$ & $\begin{array}{c}\text { Percent } \\
\text { success }\end{array}$ \\
\hline American coot & 12 & 17 \\
$\quad$ North Roadside site & 15 & 7 \\
South Roadside site & 27 & - \\
Sotal, American coot & - & 11 \\
Pied-billed grebe & 3 & 67 \\
Gadwall & 4 & 50 \\
Mallard & 3 & 0 \\
Cinnamon teal & 1 & 100 \\
\end{tabular}

\section{Observations of Waterbird Use in the Area of the Roadside Ponds}

Waterbird use of the Roadside Ponds was documented about every one to two weeks during 1988-89. Counts of ducks observed were largest just after ice breakup in the spring and during the fall. No counts were made in October. Total counts for the Roadside Ponds ranged from a minimum of five ducks, primarily blue-winged teal, in June to a maximum of 125 ducks, primarily gadwall, in September.

Numbers of American coots were largest in August and during early spring when there appeared to be an influx of coots. During 1987, however, few broods of juvenile coots were observed prior to July 24. Numbers of birds at both ponds tended to be large in April and declined through July.

Waterbirds observed during survey dates are shown in table 9. The list is not a complete survey of all waterbirds using each site but represents those species most commonly using the area. The northern harrier was observed using the site but was not represented when counts were made. The inclusion of fish-eating birds in counts made at the South Roadside Pond but not the North Roadside Pond reflected the relative lack of fish at the North Roadside Pond. Also, species that did not tolerate nearby vehicle traffic were less likely to be represented at the North Roadside Pond because the dike serves as the main access road into the refuge.

Brood counts were conducted at the Roadside Ponds in 1987, 1988, and 1989. The mean number of broods observed was 1.5 broods per count. The observations indicated a total of 13 duck and 1 pied-billed grebe broods were hatched on or near these ponds. A maximum of four American coot broods was observed in July and August. Juvenile American coots observed in August were well developed. This indicates that American coot broods were either extremely secretive in June and July or that the birds observed in August were produced in Sheppard Bottom and, by a combination of walking, short flight, and swimming, moved into the Roadside Pond complex in the later part of July or early August. 


\section{Residue in Biota from the Roadside Ponds}

Substantial effort was made to sample biological tissue at the Roadside Ponds. When data for the Roadside Ponds were aggregated for analysis and interpretation, selenium concentrations in bird eggs ranged from 3.8 to $120 \mu \mathrm{g} / \mathrm{g}$ (Peltz and Waddell, 1991), with a geometric mean concentration of $30.4 \mu \mathrm{g} / \mathrm{g}$. Similarly, selenium concentrations in cattails ranged from 6.5 to $72 \mu \mathrm{g} / \mathrm{g}$; non-emergent aquatic plants from 5.5 to $91 \mu \mathrm{g} / \mathrm{g}$, invertebrates from 10 to $71.1 \mu \mathrm{g} / \mathrm{g}$; and fish from 21.6 to $104 \mu \mathrm{g} / \mathrm{g}$. Biologically, the most contaminated area found during this study was the Roadside Pond complex.

Examination of the median and interquartile range for data from American coot eggs indicated there were no differences between selenium concentrations in tissue from birds on the two ponds (fig. 50). The presence of outlying values for tissue selenium concentrations in birds from the South Roadside Pond suggests that substantial within-site variation in selenium concentrations may occur.

\section{North Roadside Pond}

A total of 10 eggs were collected at random from 10 American coot nests from the North Roadside Pond. Selenium concentrations in American coot eggs ranged from 39 to $79 \mu \mathrm{g} / \mathrm{g}$ (Peltz and Waddell, 1991, p. 163), with a geometric mean concentration of $54.7 \mu \mathrm{g} / \mathrm{g}$ for random eggs (table 34). A total of five non-random eggs also were analyzed, and selenium concentrations ranged from $29.1 \mu \mathrm{g} / \mathrm{g}$ to $42.9 \mu \mathrm{g} / \mathrm{g}$ (Peltz and Waddell, 1991, p. 163), with a geometric mean concentration of $37.4 \mu \mathrm{g} / \mathrm{g}$. The largest concentration was in a random egg, and the smallest concentration was in a non-random egg, both from the same nest. Studies with captive-reared mallards by Heinz and others (1987), as reported by Lemly and Smith (1987), indicated that a selenium concentration of about $15 \mu \mathrm{g} / \mathrm{g}$ was associated with some degree of reproductive impairment.

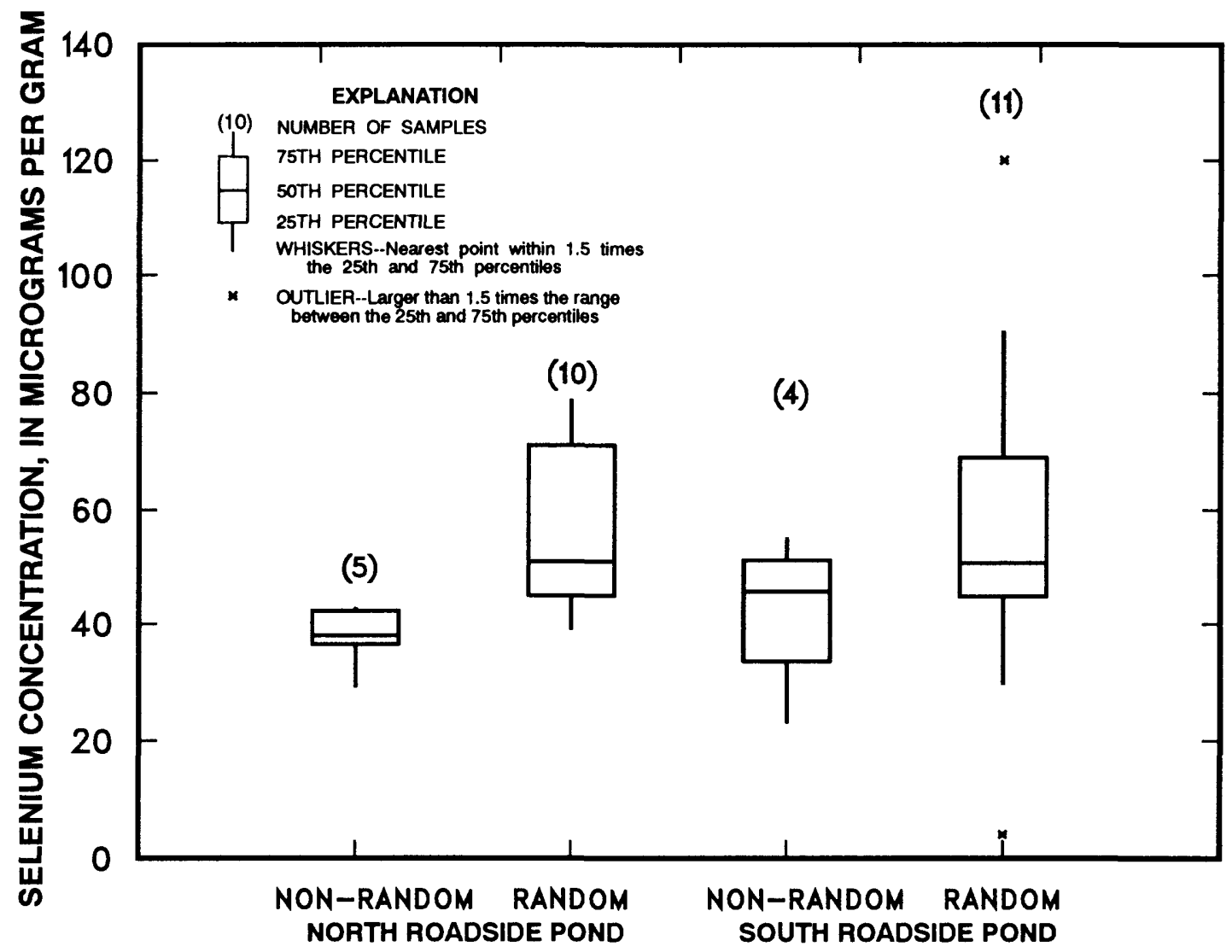

Figure 50. Selenium concentrations in non-randomly and randomly collected American coot eggs from North and South Roadside Ponds at Ouray National Wildlife Refuge. 
One randomly and four non-randomly collected gadwall eggs from two nests were analyzed. The random egg had a selenium concentration of $7.8 \mu \mathrm{g} / \mathrm{g}$, and the non-random eggs had selenium concentrations ranging from 9.6 to $23 \mu \mathrm{g} / \mathrm{g}$ (Peltz and Waddell, 1991, p. 163). The random and nonrandom eggs represent eggs from two nesting attempts in the immediate vicinity of North Roadside Pond. One nest contained eggs with 7.8 and $9.6 \mu \mathrm{g} / \mathrm{g}$ selenium, and eggs from the second nest contained 16,22 , and $23 \mu \mathrm{g} / \mathrm{g}$ selenium. Both nests were considered successful because one egg hatched in the first nest and four of eight eggs hatched in the second nest.

Two eggs from a single mallard nest located in 1988 were analyzed. Embryos in both eggs were dead when the nest was located, and the hen was still incubating. Both eggs were considered random, and both contained deformed embryos. Selenium concentrations in the embryos were 43.6 and 38.2 $\mu \mathrm{g} / \mathrm{g}$. A third egg that was addled (Charles Henny, U.S. Fish and Wildlife Service, written commun., 1988) was collected and analyzed by the Patuxent Wildlife Research Center and contained $63.9 \mu \mathrm{g} / \mathrm{g}$ selenium.

Table 34. Geometric mean selenium concentrations in bird tissue samples collected from North Roadside Pond at Ouray National Wildlife Refuge

[All egg samples are random except those indicated by NR, non-random sample; mm, millimeter; $g$, gram; $\mu \mathrm{g} / \mathrm{g}$, micrograms per gram (dry weight); - , not specified. Weight of bird egg is mean weight of contents. Mean length, weight, and moisture content are arithmetic means]

\begin{tabular}{lcccccc}
\hline Sample composition & $\begin{array}{c}\text { Sample } \\
\text { size }\end{array}$ & $\begin{array}{c}\text { Sample } \\
\text { type }\end{array}$ & $\begin{array}{c}\text { Mean } \\
\text { length } \\
(\mathrm{mm})\end{array}$ & $\begin{array}{c}\text { Mean } \\
\text { weight } \\
(\mathrm{g})\end{array}$ & $\begin{array}{c}\text { Mean } \\
\text { moisture } \\
\text { content } \\
(\text { percent })\end{array}$ & $\begin{array}{c}\text { Geometric } \\
\text { mean selenium } \\
\text { concentration } \\
(\mu \mathrm{g} / \mathrm{g})\end{array}$ \\
\hline
\end{tabular}

American coot

American coot (NR)

Gadwall

Gadwall (NR)

Mallard

Pied-billed grebe

Pied-billed grebe (NR)

Yellow-headed blackbird

American coot

American coot, Spring

Mallard, Spring

American coot, Summer

American coot, Spring

Mallard, Spring

American coot, Summer

\section{Eggs}

10

5

1

4

2

1

1

3

1

Individual

Individual

Individual

Individual

Individual

Individual

Individual

Composite

48

52

52

53

55

41

43

27

\section{Kidney}

\section{Liver}

5 Individual

1 Individual

6

$$
\text { Individual }
$$

\section{1 \\ - \\ 28 \\ 23 \\ 28 \\ 13 \\ - \\ 3}

76.5

70.2

64.2

67.0

66.3

76.2

77.6

77.8

71.4

213

75.7

76.1

73.9

78.2

77.6

69.5
54.7

37.4

7.8

16.7

40.8

63.0

88.4

12.7

\section{Muscle}

5 Individual

1 Individual

4 Individual $\begin{array}{ll}- & - \\ - & -\end{array}$
34.8

56.5

28.3

15.7

8

17.8 
Two eggs were collected from a pied-billed grebe nest. The random egg contained a selenium concentration of $63 \mu \mathrm{g} / \mathrm{g}$, and the non-random egg contained $88.4 \mu \mathrm{g} / \mathrm{g}$. Both contained dead embryos. A dead adult and a dead hatchling were found near the nest platform.

Three composite samples of yellow-headed blackbird eggs contained a geometric mean selenium concentration of $12.7 \mu \mathrm{g} / \mathrm{g}$ (table 34). The range for individual composite samples was 9.9 to $20.5 \mu \mathrm{g} / \mathrm{g}$ (Peltz and Waddell, 1991, p. 163).

Tissue samples were salvaged when possible from birds found sick or dead. Livers from five American coots found dead during April and May had a geometric mean concentration of $34.8 \mu \mathrm{g} / \mathrm{g}$ selenium (table 34). Selenium concentrations in liver samples from these birds ranged from 19 to 125 $\mu \mathrm{g} / \mathrm{g}$. Concentrations in five individual muscle samples from these same birds varied substantially, ranging from 5.82 to $84.5 \mu \mathrm{g} / \mathrm{g}$ (Peltz and Waddell, 1991, p. 163), with a geometric mean concentration of $15.7 \mu \mathrm{g} / \mathrm{g}$ (table 34). Four of the American coots were necropsied at Colorado State University. Emaciation was the cause of death for one bird, and the liver had a selenium concentration of $27 \mu \mathrm{g} / \mathrm{g}$ (muscle, $20.7 \mu \mathrm{g} / \mathrm{g}$ ). Two birds were moderately emaciated and had selenium concentrations in their livers of 23.6 and $33.5 \mu \mathrm{g} / \mathrm{g}$ (muscle, 13.1 and $5.82 \mu \mathrm{g} / \mathrm{g}$, respectively). The fourth bird had full musculature and had a selenium concentration in its liver of $19 \mu \mathrm{g} / \mathrm{g}$ (muscle, $7.23 \mu \mathrm{g} / \mathrm{g}$ ). The fifth American coot was extremely emaciated, and tissue from the breast was combined with leg muscle. The liver and muscle contained $125 \mu \mathrm{g} / \mathrm{g}$ selenium and $84.5 \mu \mathrm{g} / \mathrm{g}$, respectively.

One American coot was captured live but died about two hours later. The kidney from this bird contained a concentration of $213 \mu \mathrm{g} / \mathrm{g}$ selenium. Results of the necropsy of this bird by the National Wildlife Health Laboratory, combined with the large selenium concentration in the kidney, indicated that death was associated with selenium poisoning. A single wild mallard found dead had moderate musculature and contained selenium concentrations of $56.5 \mu \mathrm{g} / \mathrm{g}$ in the liver and $8 \mu \mathrm{g} / \mathrm{g}$ in the muscle.

The livers of American coots, sampled during the summer to assess brood-rearing conditions, had a geometric mean selenium concentration of $28.3 \mu \mathrm{g} / \mathrm{g}$ (table 34). Muscle tissue had a selenium concentration of $17.8 \mu \mathrm{g} / \mathrm{g}$. Both of these concentrations were similar to selenium concentrations in American coots found dead in the spring that were believed to have died from selenium poisoning.

Fathead minnows were the only fish species observed in the North Roadside Pond. Whole-body selenium concentrations in the fish ranged from 64.2 to $100 \mu \mathrm{g} / \mathrm{g}$ (Peltz and Waddell, 1991, p. 165), with a geometric mean of $82.6 \mu \mathrm{g} / \mathrm{g}$ (table 35). The sample that contained $100 \mu \mathrm{g} / \mathrm{g}$ of selenium was a composite that included fish from the North and South Roadside Ponds.

No adult amphibians were collected in this study. Tadpoles were collected opportunistically once at this site and contained $65.4 \mu \mathrm{g} / \mathrm{g}$ selenium.

A total of 44 samples of plants were analyzed from North Roadside Pond. Selenium concentrations ranged from $1.7 \mu \mathrm{g} / \mathrm{g}$ in bulrush seedheads to $91 \mu \mathrm{g} / \mathrm{g}$ in a sample of potamogeton (Peltz and Waddell, 1991, p. 173). The largest geometric mean for any plant group was $30.3 \mu \mathrm{g} / \mathrm{g}$ in bluegreen algae. Samples are summarized by taxonomic group in table 35 . Selenium concentrations in some taxa appear to be strongly influenced by season. Chara sampled in April had selenium concentrations that ranged from 39 to $63 \mu \mathrm{g} / \mathrm{g}$; however, in May through September, selenium concentrations ranged from 11.9 to $20.1 \mu \mathrm{g} / \mathrm{g}$ (Peltz and Waddell, 1991, p. 173). A similar relation was observed for potamogeton, but the sample size was much smaller. In April, these samples were largely plants that had overwintered under the ice, whereas later, they had substantial new growth. Selenium concentrations in the water were largest in early spring. Large concentrations in forage plants may pose a serious hazard to migrating waterfowl and birds initiating egg laying in April (4 to $8 \mu \mathrm{g} / \mathrm{g}$ of some forms of selenium in foods is associated with reduced reproductive success in mallards (Heinz and others, 1989)).

A seasonal relation was not readily apparent for cattail and bulrush, possibly because differences were masked by a lack of sequential samples at specific locations. A series of usually single 
Table 35. Geometric mean selenium concentrations in biological samples collected from North Roadside Pond at Ouray National Wildlife Refuge

[ $\mu \mathrm{g} / \mathrm{g}$, micrograms per gram (dry weight). Mean moisture content is an arithmetic mean]

\begin{tabular}{lccc}
\hline Organism & $\begin{array}{c}\text { Sample } \\
\text { size }\end{array}$ & $\begin{array}{c}\text { Mean } \\
\text { moisture } \\
\text { content } \\
\text { (percent) }\end{array}$ & $\begin{array}{c}\text { Geometric } \\
\text { mean selenium } \\
\text { concentration } \\
(\mu \mathrm{g} / \mathrm{g})\end{array}$ \\
\hline & Vertebrates & & \\
Fathead minnow & 3 & 81.0 & 82.6 \\
Tadpole & 1 & 89.3 & 65.4 \\
& Plants & & \\
Blue-green algae & 2 & 82.5 & 30.3 \\
Chara & 12 & 80.2 & 24.2 \\
Filamentous green algae & 7 & 82.3 & 11.4 \\
Potamogeton/Widgeongrass & 5 & 88.3 & 14.6 \\
Hardstem bulrush & 4 & 76.1 & 13.9 \\
Hardstem bulrush (seed) & 1 & 18.0 & 1.7 \\
Cattail & 12 & 86.6 & 22.3 \\
Cattail (seed) & 1 & 55.5 & 7.4 \\
& Invertebrates & & \\
Invertebrates, mixed (excludes snails) & 12 & 83.6 & 26.9 \\
& & & \\
\hline
\end{tabular}

composite samples of cattail were collected monthly in 1988 from April through September and had selenium concentrations of $16,22.8,35.1,22,24$, and $19 \mu \mathrm{g} / \mathrm{g}$. Schuler (1989) indicates that cattail at Kesterson NWR had larger selenium concentrations in August than in May and December, possibly representing uptake of selenium coincident with seasonal patterns of plant growth and senescence.

Because the rhizome contains the largest selenium concentration (Schuler, 1989), large seasonal fluctuations were expected to be somewhat independent of the changes in water concentrations. The sediment within individual ponds varies in content of elements and quantities of organic material. Selenium concentrations in sediment at four locations in the South Roadside Pond and five locations within the North Roadside Pond, selenium concentrations in three genera of plants, and volatile-solids concentrations (an indicator of organic carbon) in the sediments are shown in table 36. There is a generally positive correlation between volatile-solids and selenium concentration in sediment $\left(R^{2}=0.67\right)$ but little correlation between selenium concentrations in sediment and in plants in these ponds.

Selenium concentrations in invertebrate samples (excluding snails) from the North Roadside Pond ranged from $12.0 \mu \mathrm{g} / \mathrm{g}$ to $49.0 \mu \mathrm{g} / \mathrm{g}$ (table 37), with a geometric mean of 26.9. Snails had a geometric mean selenium concentration of $10.3 \mu \mathrm{g} / \mathrm{g}$. Concentrations in invertebrates changed rapidly over a short period of time. Samples collected April 27, 1989, contained selenium concentrations about twice as large as those collected April 5, 1989, at the same sites using the same techniques. The invertebrates were similar in taxonomic composition during both sampling periods, but Corixidae (water boatmen) comprised a greater proportion of the volume of the samples during the first sampling period. Examination of the data suggests that invertebrates had small selenium concentrations in September through mid-April and large concentrations from mid-April through July. 
Table 36. Volatile-solids concentrations in sediment and selenium concentrations in sediment and plants from nine subsites at South and North Roadside Ponds, Ouray National Wildlife Refuge, March and April, 1989

[Concentration of volatile solids given in milligrams per gram; concentration of selenium given in micrograms per gram; -, no data]

\begin{tabular}{lcccccccccc}
\hline & \multicolumn{3}{c}{ South Roadside Pond } & \multicolumn{5}{c}{ North Roadside Pond } \\
\cline { 3 - 8 } \multicolumn{1}{c}{ Sample } & Site 1 & Site 2 & Site 3 & Site 4 & Site 5 & Site 6 & Site 7 & Site 8 & Site 9 \\
\hline Sediment, volatile solids & 35.4 & 53.6 & 28.2 & 34.9 & 47.7 & 102 & 131 & 64.5 & 73.7 \\
Sediment, selenium & 12 & 11 & 4 & 8 & 7 & 25 & 23 & 20 & 26 \\
Cattail & 9.6 & 17.9 & 13 & 31 & 22 & 14.4 & 72 & 14.1 & 18.6 \\
Hardstem bulrush & 12 & - & - & 15 & 9.7 & 12 & - & 27 & 12 \\
Chara & 27 & - & - & - & 49 & 39 & - & 54 & 63 \\
& & & & & & & & & \\
\hline
\end{tabular}

Table 37. Selenium concentrations in samples of invertebrates (excluding snails) at the Roadside Ponds, Ouray National Wildlife Refuge, March-September, 1989

[All concentrations in micrograms per gram; -, no data]

\begin{tabular}{ccccccccc}
\hline Site & March & $\begin{array}{c}\text { Early } \\
\text { April }\end{array}$ & $\begin{array}{c}\text { Late } \\
\text { April }\end{array}$ & May & June & July & August & September \\
\hline North Roadside Pond & 13 & 16.6 & 38.1 & - & 32.8 & 40.9 & - & 12 \\
& - & 17.2 & 40.3 & - & 49 & 43 & - & - \\
South Roadside Pond & - & 24 & 30.5 & - & - & - & - & - \\
& - & 14.5 & 40.4 & - & 49.3 & 17.9 & - & - \\
& - & 12 & 53.3 & - & 71.1 & - & - & - \\
\hline
\end{tabular}

\section{South Roadside Pond}

A total of 11 eggs were collected at random from 11 American coot nests from the South Roadside Pond (table 38). Selenium concentrations in American coot eggs ranged from 4.1 to $120 \mu \mathrm{g} / \mathrm{g}$ (Peltz and Waddell, 1991, p. 177), with a geometric mean concentration of $45.8 \mu \mathrm{g} / \mathrm{g}$ for random eggs (table 38). A total of four non-random eggs also were analyzed, and concentrations ranged from $23 \mu \mathrm{g} / \mathrm{g}$ to $55.2 \mu \mathrm{g} / \mathrm{g}$, with a geometric mean concentration of $40.3 \mu \mathrm{g} / \mathrm{g}$. The largest and smallest selenium concentrations were in random eggs.

Two randomly collected eggs from two unsuccessful gadwall nests were collected and analyzed. These eggs had selenium concentrations of 3.8 and $16 \mu \mathrm{g} / \mathrm{g}$ (Peltz and Waddell, 1991, p. 177), with a geometric mean of $7.8 \mu \mathrm{g} / \mathrm{g}$ (table 38). The nest containing the egg with a selenium concentration of $3.8 \mu \mathrm{g} / \mathrm{g}$ had two eggs that failed to hatch when placed in an incubator, and a third egg was analyzed and contained $12.1 \mu \mathrm{g} / \mathrm{g}$ selenium (Charles Henny, U.S. Fish and Wildlife Service, written commun., 1989). The random egg taken from the second nest was dead at early incubation, and the egg contents had deteriorated. 
Table 38. Geometric mean selenium concentrations in biological samples collected from South Roadside Pond and in fish samples collected nationwide by the National Contaminant Biomonitoring Program

[All egg samples are random except those indicated by NR, non-random sample; mm, millimeter; $g$, gram; $\mu \mathrm{g} / \mathrm{g}$, micrograms per gram (dry weight); - , not specified. Weight of bird egg is mean weight of contents. Mean length, weight, and moisture content are arithmetic means. NCBP, National Contaminant Biomonitoring Program, from Schmitt and Brumbaugh, 1990 (1984 geometric mean concentration, 85th percentile, converted to dry weight using 75 percent moisture)]

\begin{tabular}{lcccccc}
\hline Species & $\begin{array}{c}\text { Sample } \\
\text { size }\end{array}$ & $\begin{array}{c}\text { Sample } \\
\text { type }\end{array}$ & $\begin{array}{c}\text { Mean } \\
\text { length } \\
(\mathrm{mm})\end{array}$ & $\begin{array}{c}\text { Mean } \\
\text { weight } \\
(\mathrm{g})\end{array}$ & $\begin{array}{c}\text { Mean } \\
\text { moisture } \\
\text { content } \\
\text { (percent) }\end{array}$ & $\begin{array}{c}\text { Geometric } \\
\text { mean selenium } \\
\text { concentration } \\
(\mu \mathrm{g} / \mathrm{g})\end{array}$ \\
\hline
\end{tabular}

\begin{tabular}{|c|c|c|c|c|c|c|}
\hline \multicolumn{7}{|c|}{ Bird eggs } \\
\hline American coot & 11 & Individual & 49 & 22 & 77.5 & 45.8 \\
\hline American coot (NR) & 4 & Individual & 47 & 19 & 69.3 & 40.3 \\
\hline Cinnamon teal & 1 & Individual & 46 & 24 & 69.7 & 7.9 \\
\hline Gadwall & 2 & Individual & 54 & 36 & 68.4 & 7.8 \\
\hline Mallard & 2 & Individual & 56 & 46 & 70.5 & 12.4 \\
\hline Redhead & 1 & Individual & 61 & 53 & 69.8 & 19.7 \\
\hline Yellow-headed blackbird & 1 & Composite & 27 & - & 80.2 & 9.8 \\
\hline \multicolumn{7}{|c|}{ Bird liver } \\
\hline American coot & 3 & Individual & - & - & 74.1 & 26 \\
\hline Great blue heron & 1 & Individual & - & - & 78.0 & 38 \\
\hline \multicolumn{7}{|c|}{ Fish } \\
\hline Black bullhead & 2 & Composite & 181 & 78 & 82.3 & 39.3 \\
\hline Common carp & 5 & Composite & 309 & 485 & 79.3 & 42.1 \\
\hline Green sunfish & 3 & Composite & 156 & 73 & 75.9 & 40.7 \\
\hline Fish, NCBP nationwide & - & Composite & - & - & 75.0 & 2.9 \\
\hline \multicolumn{7}{|c|}{ Plants } \\
\hline Chara & 4 & Composite & - & - & 77.7 & 27.7 \\
\hline Filamentous green algae & 4 & Composite & - & - & 80.1 & 15.9 \\
\hline Potamogeton/Widgeongrass & 9 & Composite & - & - & 87.0 & 24.9 \\
\hline Hardstem bulrush & 2 & Composite & - & - & 71.8 & 13.4 \\
\hline Cattail & 8 & Composite & - & - & 88.2 & 14.0 \\
\hline \multicolumn{7}{|c|}{ Invertebrates } \\
\hline Invertebrates, mixed & 8 & Composite & - & 18.4 & 83.8 & 27.3 \\
\hline
\end{tabular}

One egg from each of two mallard nests was analyzed in 1989. Both nesting attempts were abandoned. The random eggs were believed to be alive when examined, but incubation was estimated to have been only one to three days. One cinnamon teal nest was monitored, and all eggs were believed to have hatched. A random egg collected from the nest contained $7.9 \mu \mathrm{g} / \mathrm{g}$ of selenium. 
One egg collected at random from a redhead nest contained $19.7 \mu \mathrm{g} / \mathrm{g}$ selenium. It was not certain if the embryo (age about 10 days) was alive when collected. None of the remaining six eggs hatched: two eggs had addled contents, two appeared normal, and two had gross abnormalities. It is not known whether the two normal-appearing embryos died before the nest was abandoned or whether they died because it was abandoned, but they were at or near hatching age. One composite sample of yellow-headed blackbird eggs contained a selenium concentration of $9.8 \mu \mathrm{g} / \mathrm{g}$.

Tissue samples were taken from an adult great blue heron found dead in May. The bird was necropsied by the National Wildlife Health Laboratory, and the emaciated condition was believed to be due to selenium poisoning because the liver contained $38 \mu \mathrm{g} / \mathrm{g}$ selenium. The fractured leg and infections of the leg and heart were believed to be secondary results of the inability of the heron to fly normally. One American coot was found dead, but no tissues were analyzed and the cause of death was not determined. This bird was considered thin (necropsied at Colorado State University), with a body weight of only $230 \mathrm{~g}$.

American coots were sampled during the summer to assess tissue concentrations during the brood-rearing season. Livers from three juvenile American coots had a geometric mean concentration of $26 \mu \mathrm{g} / \mathrm{g}$ (table 38) and ranged from 18 to $36 \mu \mathrm{g} / \mathrm{g}$ (Peltz and Waddell, 1991, p. 177). These concentrations were similar to the two American coot livers collected concurrently at the North Roadside Pond and should be considered part of the same population on the basis of observed marked and wing-pinioned mallards that walked and swam between the North and South Roadside Ponds.

A total of 10 samples of fish contained selenium concentrations that ranged from individual values of 21.6 to $104 \mu \mathrm{g} / \mathrm{g}$ (Peltz and Waddell, 1991, p. 177) and were 7 to 35 times as large as the baseline concentration of $2.9 \mu \mathrm{g} / \mathrm{g}$ reported by the National Contaminant Biomonitoring Program. In addition, a composite sample of fathead minnows from the South and North Roadside Ponds contained $100 \mu \mathrm{g} / \mathrm{g}$ selenium.

Geometric mean selenium concentrations in composite samples of three species of fish were similar: $42.1 \mu \mathrm{g} / \mathrm{g}$ in common carp, $40.7 \mu \mathrm{g} / \mathrm{g}$ in green sunfish, and $39.3 \mu \mathrm{g} / \mathrm{g}$ in black bullhead (table 38). In contrast to these data, the fish from Stewart Lake had selenium concentrations in black bullhead that were about one-half the selenium concentrations in common carp. At the South Roadside Pond, selenium concentrations in black bullhead were about twice as large as at Stewart Lake. Concentrations in common carp were similar at both sites.

Selenium concentrations in the three species of fish collected in July 1988 at the South Roadside Pond were substantially larger (at least twice as large) than in samples collected on other dates at this site. For common carp, one sample collected on this date had a selenium concentration of $104 \mu \mathrm{g} / \mathrm{g}$, which is about twice the maximum concentration found for samples of common carp collected at other times that had selenium concentrations ranging from 21.6 to $52.2 \mu \mathrm{g} / \mathrm{g}$ (Peltz and Waddell, 1991, p. 177). There was a similar relation for samples of green sunfish and black bullheads. Patterns of selenium in invertebrates and rooted aquatic plants do not appear to explain this increase.

A total of 27 plant samples were collected at the South Roadside Pond. Geometric mean selenium concentrations ranged from $13.4 \mu \mathrm{g} / \mathrm{g}$ in bulrush to $27.7 \mu \mathrm{g} / \mathrm{g}$ in chara. Samples are summarized by taxonomic group in table 38.

Selenium concentrations in some plants from the North Roadside Pond appeared to be strongly influenced by season, but the seasonal patterns were not necessarily the same at the South Roadside Pond. For example, chara at the South Roadside Pond had selenium concentrations that were large for all four samples collected in April, June, July, and August. The sample collected in April at the South Roadside Pond contained smaller selenium concentrations than samples collected on the same approximate date from the North Roadside Pond, but the remaining three samples had selenium concentrations about 50 percent larger than eight samples at the North Roadside Pond that were collected during the same time period. Selenium concentrations in widgeongrass at the South 
Roadside Pond, however, exhibited fluctuations similar to those observed for chara at the North Roadside Pond. Widgeongrass collected in April had selenium concentrations that ranged from 46 to $76 \mu \mathrm{g} / \mathrm{g}$, whereas samples collected during July and August had concentrations of 9.4 and $12.4 \mu \mathrm{g} / \mathrm{g}$ (Peltz and Waddell, 1991, p. 181, 187). A single sample collected in June had a selenium concentration of $38.4 \mu \mathrm{g} / \mathrm{g}$. Samples collected in April were largely plants that overwintered under the ice, whereas later, they predominantly consisted of new growth.

The seasonal relation was not apparent for cattail, as both the largest and smallest selenium concentrations in cattail at the South Roadside Pond were collected on the same date. In addition, there appeared to be a weak correlation between selenium concentrations in cattail and in sediment (table 36).

Selenium concentrations in invertebrates ranged from 12 to $71.1 \mu \mathrm{g} / \mathrm{g}$ and were slightly larger than concentrations from invertebrates in the North Roadside Pond (table 37). Selenium concentrations tended to be smaller in early April than later in the summer.

\section{Bioconcentration of Selenium at the Roadside Ponds by Captive Mallards}

During 1989, 50 (25 males and 25 females) captive-reared adult mallards with clipped flightfeathers were acquired from a commercial source. Birds were banded, weighed, evaluated for general condition, and marked with numbered poultry wing badges. Three males and three females were randomly selected and sacrificed. The geometric mean selenium concentration in these control birds was $2.8 \mu \mathrm{g} / \mathrm{g}$ in liver (table 39). On March 22, 1989, 9 males and 12 females were released on North Roadside Pond, and 13 males and 10 females were released on South Roadside Pond.

Birds were recaptured and sacrificed at approximately weekly intervals until no birds remained. On March 29, 1988, four males and four females were taken, two each from each pond. By the second week, some movement of birds between the two ponds was evident, and attempts to segregate birds in each pond were discontinued. Between April 3 and 5, four males and four females were sacrificed. By the third week, only a few birds were still alive because many birds had died in addition to those sacrificed. Collections had not been planned for the third week, but it appeared that the birds would not survive to the fourth week; therefore, one male was collected. During the fourth week one male remained but died just before being collected. This bird and two others found recently dead were included as part of the collection. A male found dead in a predator control trap and a female that died during the collection period also were included in data for the second week.

All collected birds were necropsied under contract with the Colorado Veterinary Diagnostic Laboratory, Colorado State University. Gross necropsies were performed and samples of liver and breast muscle taken. On the basis of examination of the three female control birds, the females were sexually inactive when released at the start of the experiment, but at the end of week 1,50 percent of the four sacrificed females were classified as having ovaries that were in the early stages of activity. At the end of week 2, all of the females sacrificed had ovaries classified as inactive. Males collected as controls at release all had active testes. At the end of week 1, 50 percent of the males had testes that were small and inactive. At the end of the week 2 (and during weeks 3 and 4), all males had testes that were inactive.

Body condition, as indicated by breast musculature, also followed a pattern of progressive atrophy. All six control birds had full breast musculature at the start of the experiment, but by the end of the first week, 25 percent of the females and 75 percent of the males were mildly emaciated. At the end of the second week, all remaining birds collected were considered markedly emaciated.

The examining veterinarian concluded that these birds did not appear to be foraging correctly, were losing weight rapidly, and appeared to be starving to death. Analysis of liver and breast tissue of these birds indicated that substantial quantities of selenium had been ingested and incorporated into tissues (table 39). Concentrations of antimony, arsenic, barium, beryllium, nickel, and vanadium 
in all samples were less than detection levels. After one week, the geometric mean selenium concentration in liver of mallards recovered was $26.8 \mu \mathrm{g} / \mathrm{g}$ and after two weeks, $46.4 \mu \mathrm{g} / \mathrm{g}$. Only single birds were available for the third and fourth weeks, but they also showed increasing selenium concentrations.

Selenium concentration in the livers of exposed birds ranged from $9.93 \mu \mathrm{g} / \mathrm{g}$ in a female after one week to $106 \mu \mathrm{g} / \mathrm{g}$ in a male after four weeks. Selenium concentration in muscle tissue ranged from $0.93 \mu \mathrm{g} / \mathrm{g}$ in a female after one week to $37.4 \mu \mathrm{g} / \mathrm{g}$ in the single male recovered after four weeks. The livers of control birds at the start of the experiment contained selenium concentrations ranging from 2.35 to $3.47 \mu \mathrm{g} / \mathrm{g}$, and in muscle ranging from 0.82 to $1.28 \mu \mathrm{g} / \mathrm{g}$. There was considerable overlap in the selenium concentrations of males and females, and the difference shown in figure 51 is not significant.

There was an increased rate of selenium bioconcentration in livers of mallards sampled randomly at approximately one-week intervals (fig. 52), but sample sizes were small at time periods greater than two weeks. Heinz and others (1990) made a similar comparison under laboratory conditions using feed containing known selenomethionine concentrations. They also found rapid

Table 39. Geometric mean selenium concentrations in tissue samples from captive-reared mallards collected on different dates

[Mean moisture content is an arithmetic mean; $\mu \mathrm{g} / \mathrm{g}$, micrograms per gram (dry weight)]

\begin{tabular}{|c|c|c|c|c|}
\hline Sex & $\begin{array}{l}\text { Collection } \\
\text { date }\end{array}$ & $\begin{array}{l}\text { Sample } \\
\text { size }\end{array}$ & $\begin{array}{l}\text { Mean } \\
\text { moisture } \\
\text { content } \\
\text { (percent) }\end{array}$ & $\begin{array}{c}\text { Geometric } \\
\text { mean selenium } \\
\text { concentration } \\
(\mu \mathrm{g} / \mathrm{g})\end{array}$ \\
\hline \multicolumn{5}{|c|}{ Liver } \\
\hline Female & $3-22-89$ & 3 & 67.7 & 3.0 \\
\hline Male & $3-22-89$ & 3 & 71.5 & 2.6 \\
\hline Female, male & $3-22-89$ & 6 & 69.6 & 2.8 \\
\hline Female & $3-29-89$ & 4 & 70.9 & 21.4 \\
\hline Male & $3-29-89$ & 4 & 75.0 & 33.7 \\
\hline Female, male & $3-29-89$ & 8 & 73.0 & 26.8 \\
\hline Female & $4-3$ to $4-5-89$ & 5 & 76.7 & 42.3 \\
\hline Male & $4-3$ to $4-5-89$ & 5 & 77.2 & 51.0 \\
\hline Female, male & $4-3$ to $4-5-89$ & 10 & 77.0 & 46.4 \\
\hline \multicolumn{5}{|c|}{ Muscle } \\
\hline Female & $3-22-89$ & 3 & 70.7 & 1.0 \\
\hline Male & $3-22-89$ & 3 & 71.8 & 1.0 \\
\hline Female, male & $3-22-89$ & 6 . & 71.2 & 1.0 \\
\hline Female & 3-29-89 & 4 & 73.1 & 2.3 \\
\hline Male & 3-29-89 & 4 & 76.1 & 4.0 \\
\hline Female, male & $3-29-89$ & 8 & 74.6 & 3.0 \\
\hline Female & $4-3$ to $4-5-89$ & 5 & 78.1 & 4.3 \\
\hline Male & $4-3$ to $4-5-89$ & 5 & 78.7 & 8.1 \\
\hline
\end{tabular}




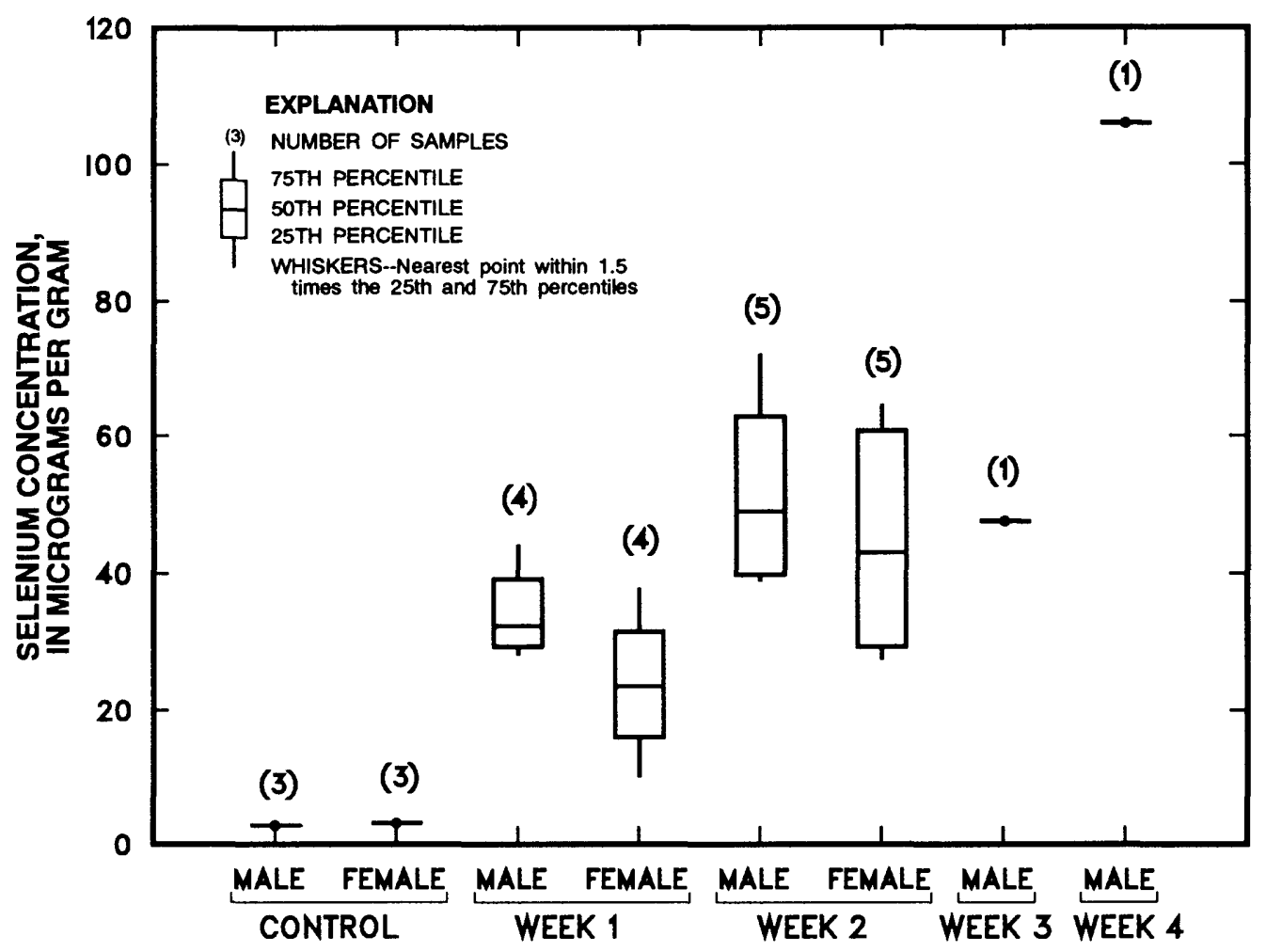

Figure 51. Selenium concentrations in the livers of captive-reared mallards released at the Roadside

Ponds in Ouray National Wildlife Refuge, 1989.

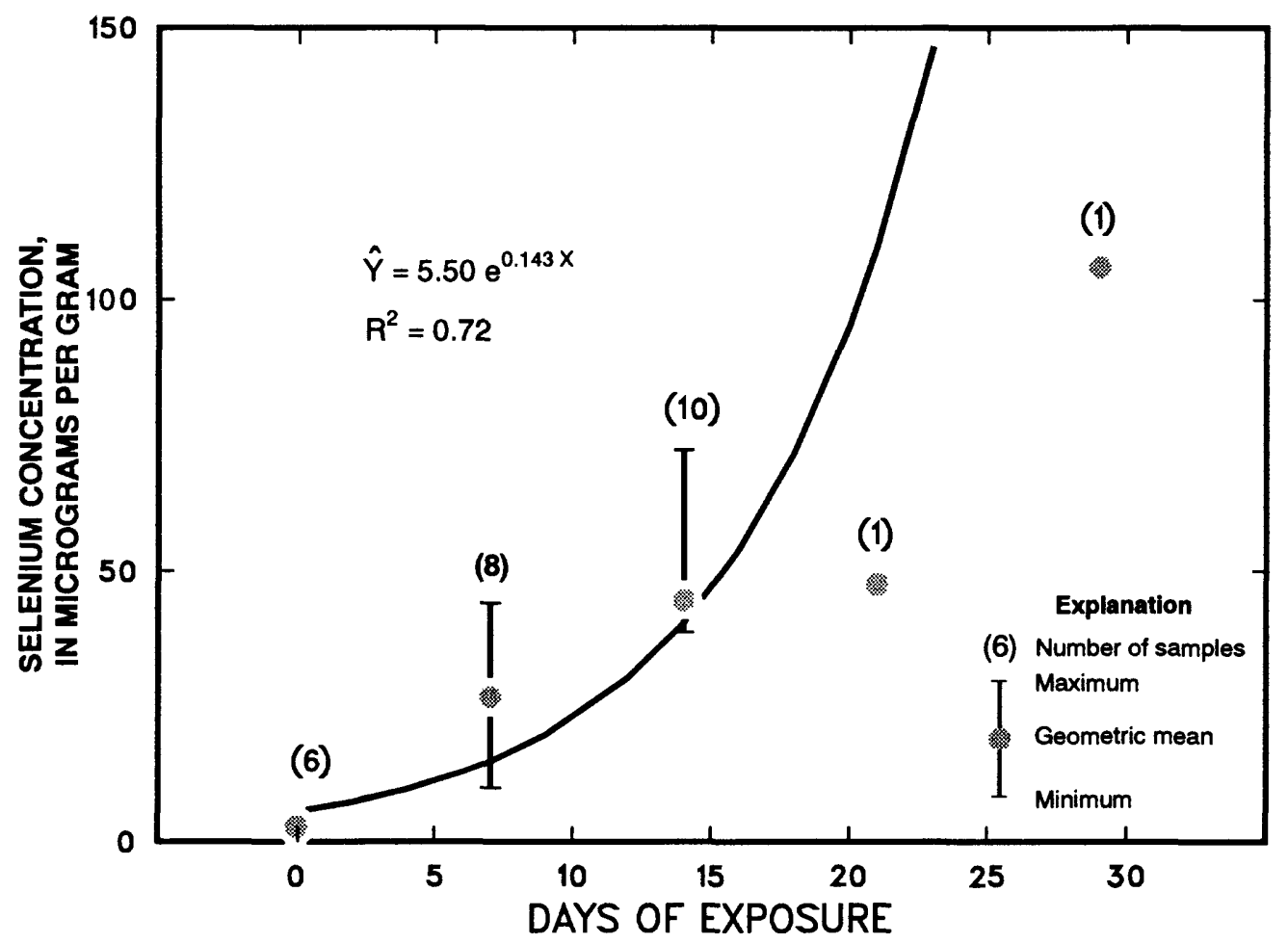

Figure 52. Selenium concentrations in mallard livers after variable number of days of exposure. 
increases in selenium concentrations in liver tissue. A comparison of regression lines indicates that different rates of selenium accumulation occurred in the Ouray NWR than were determined by Heinz and others (1990). After seven days of exposure, birds at Ouray NWR had a geometric mean selenium concentration of $26.8 \mu \mathrm{g} / \mathrm{g}$ (dry weight) in the liver. This concentration is about equal to the selenium concentration found in the livers of the birds on controlled diets reported by Heinz and others (1990).

The Heinz study found that little additional increase in selenium concentration in bird livers occurred through day 42 . In contrast, birds collected during the second week at Ouray NWR had selenium concentrations in liver that increased to $46.4 \mu \mathrm{g} / \mathrm{g}$ dry weight, and the single birds taken during the third and fourth weeks had 47.6 and $106 \mu \mathrm{g} / \mathrm{g}$. The bird collected during the fourth week had a selenium concentration in its liver $(106 \mathrm{ug} / \mathrm{g})$ that was more than three times the maximum concentration accumulated by birds in the study by Heinz and others (1990).

There are several known differences between the study at Ouray NWR and the laboratory study by Heinz and others (1990). Selenium concentration in potential food items was larger in the study at Ouray NWR, possibly as much as eight times larger (potamogeton at the North Roadside Pond contained $91 \mu \mathrm{g} / \mathrm{g}$ selenium dry weight on April 4, compared to laboratory feed containing a selenium concentration of about $11.4 \mu \mathrm{g} / \mathrm{g}$ dry weight: $10 \mu \mathrm{g} / \mathrm{g}$ with 2 percent added moisture in a feed that contained about 10 percent moisture). Samples from Ouray NWR consisted of surviving birds and may not represent the mean for all birds released. Birds were released at Ouray NWR without any acclimation to the site or to native foods.

Selenium concentrations also increased in breast muscle (fig. 53). The curve suggested an increasing rate of accumulation, although the few samples with high selenium concentrations in the muscle weaken the strength of the relation. Selenium concentrations in muscle of mallards collected at the Roadside Ponds on day 14 were slightly less than half of that predicted by the study by Heinz and others (1990) using mallards under controlled feeding conditions. The selenium concentration in

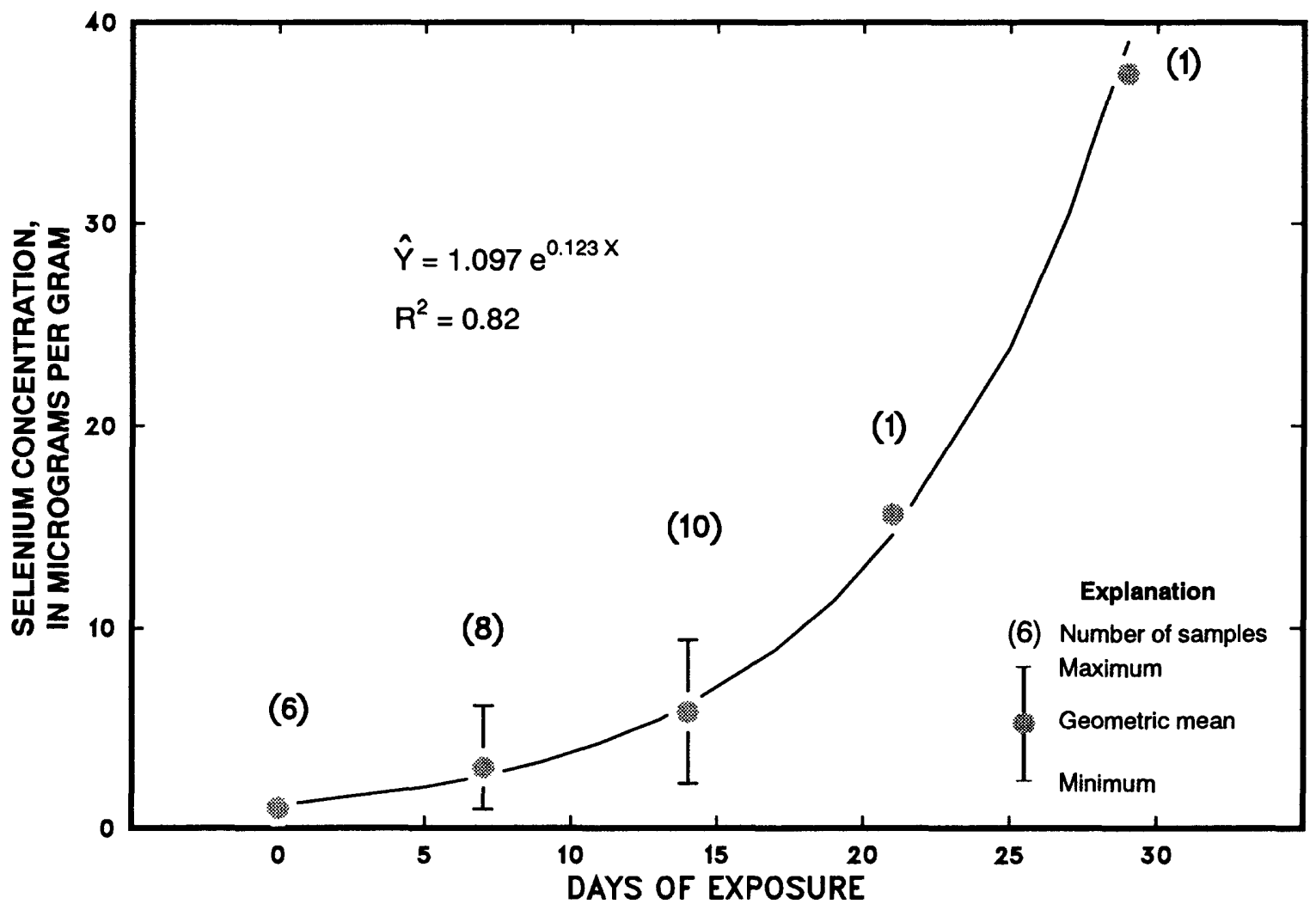

Figure 53. Selenium concentrations in mallard breast muscle after variable number of days of exposure. 
the single mallard collected on day 21 was still smaller than that reported by Heinz for day 14; however, the selenium concentration in a single mallard collected on day 29 exceeded all concentrations reported by Heinz through day 42. Reasons for the difference in rate of uptake into the muscle are not known. Possible explanations include (1) The more rapid uptake of larger selenium concentrations in the livers of the mallards at Ouray NWR may reflect a more lethal situation: the birds may go off feed quicker and, therefore, do not accumulate as much into the muscle tissue; and (2) diets were different, one being a balanced diet with added seleno-DL-methionine and the other a naturally occurring seasonal assortment of plants and invertebrates with biologically incorporated selenium (believed to be selenomethionine) that was probably less nutritionally balanced than the prepared diet.

The weight of the released mallards decreased markedly with time of exposure (fig. 54). Males lost less weight than females, but there was considerable overlap in the ranges. Males sampled the second week had lost about the same quantity of weight as the females. At the same time, birds were dying before being sampled. Only two of these were suitable for necropsy, and their data were included in the summary. The remainder died at dates beyond the sample schedule. The carcasses had been at least partially eaten by the time they were found, and it was not possible to determine if they were killed by predators or were scavenged. No tissues were sampled from these birds.

\section{Selenium in Biota from Additional Sites at Ouray National Wildlife Refuge}

Limited sampling of biological tissue was done on the south side of the Green River at Ouray NWR. Most of the sampling was done in 1989 at Woods Pool. Two randomly collected Canada goose eggs had a geometric mean selenium concentration of $4.17 \mu \mathrm{g} / \mathrm{g}$, but five non-randomly collected Canada goose eggs contained a geometric mean selenium concentration of $3.18 \mu \mathrm{g} / \mathrm{g}$. One of the non-

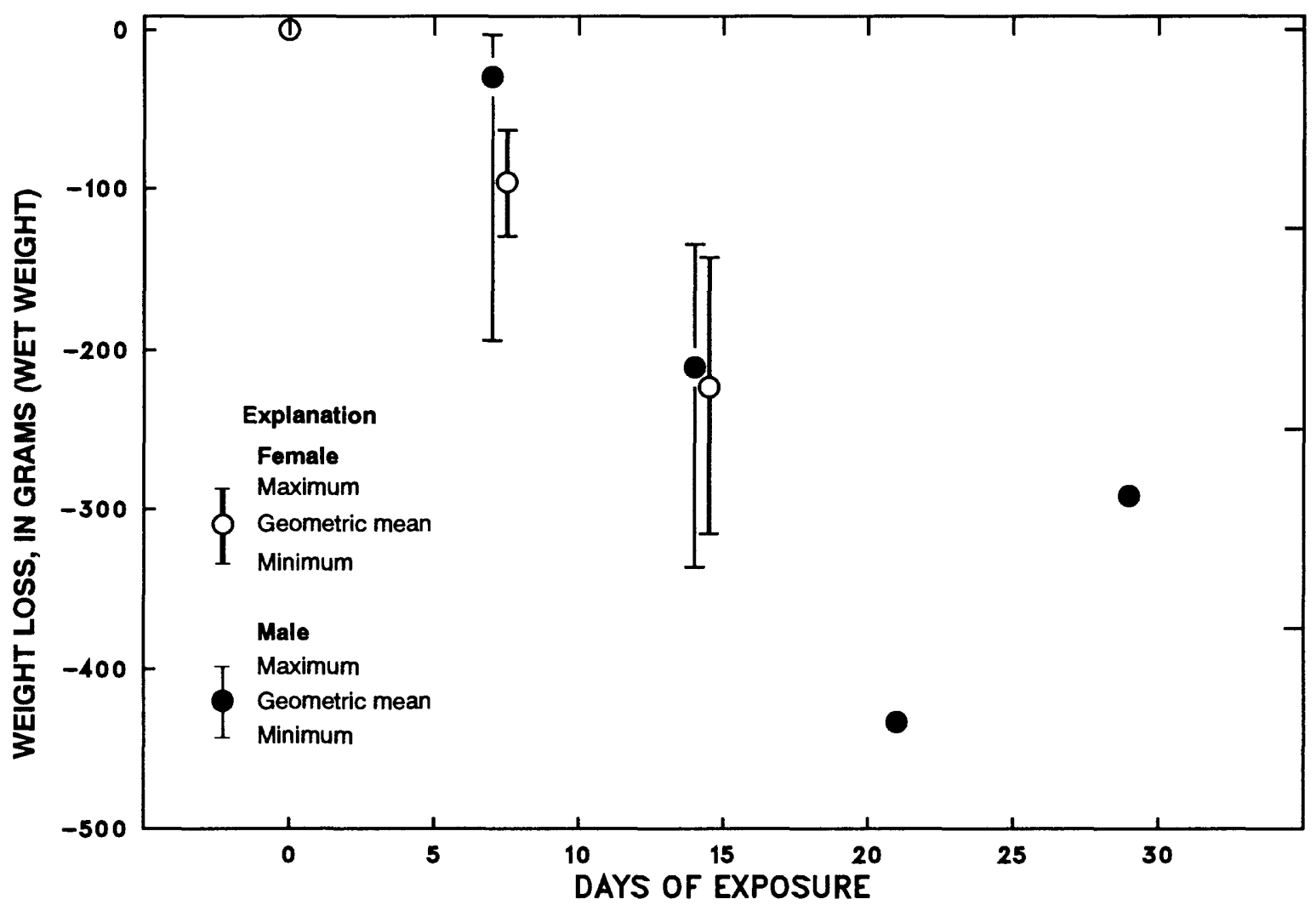

Figure 54. Weight loss in mallards exposed to naturally occurring selenium at the Roadside Ponds in Ouray National Wildlife Refuge. 
randomly collected Canada goose eggs contained a deformed goose embryo with a selenium concentration of $2.96 \mu \mathrm{g} / \mathrm{g}$. Selenium concentrations in the eggs ranged from 2.1 to $6.2 \mu \mathrm{g} / \mathrm{g}$ (Peltz and Waddell, 1991, p. 189).

Six American coot eggs were collected near Woods Pool. Selenium concentrations ranged from $3.4 \mu \mathrm{g} / \mathrm{g}$ to $9.5 \mu \mathrm{g} / \mathrm{g}$, with a geometric mean concentration of $5.4 \mu \mathrm{g} / \mathrm{g}$. Three gadwall eggs collected randomly had selenium concentrations of $2.4,3.2$, and $4.2 \mu \mathrm{g} / \mathrm{g}$ (Peltz and Waddell, 1991, p. 189). The largest selenium concentration found in an egg of any species of bird at any site on the south side of the Green River in Ouray NWR was $13.4 \mu \mathrm{g} / \mathrm{g}$ in a randomly collected pied-billed grebe egg from Woods Pool.

\section{Residue in Bald and Golden Eagles at Ouray National Wildlife Refuge and Pelican Lake}

Bald and golden eagles are common residents of Ouray NWR, Stewart Lake WMA, Pelican Lake, and Pariette Wetlands during spring migration. As many as 50 or more eagles have been observed roosting in Ouray NWR and feeding in the vicinity. Eagles were observed feeding on winterkilled common carp at pond S5 and on migrating American coots. Blood samples were collected from ten bald eagles and nine golden eagles near Ouray NWR and Pelican Lake.

Selenium concentrations in the blood of bald eagles ranged from 2 to $5.3 \mu \mathrm{g} / \mathrm{g}$ (dry weight) (Peltz and Waddell, 1991, p. 189) with a geometric mean concentration of $3.26 \mu \mathrm{g} / \mathrm{g}$ (table 40). Fifteen bald eagles, captured during 1986-88 at the Rocky Mountain Arsenal, Colorado, had concentrations of 0.50 to $0.93 \mu \mathrm{g} / \mathrm{g}$, wet weight (R. DeWeese, written commun., 1989). Four bald eagles trapped during winter 1987 near Great Salt Lake, Utah, had selenium concentrations in blood of 0.4-1.8 $\mu \mathrm{g} / \mathrm{g}$ wet weight (B. Waddell, U.S. Fish and Wildlife Service, unpublished data, 1987). Concentrations in this study were similar, ranging from 0.29 to $1.15 \mu \mathrm{g} / \mathrm{g}$ (wet weight) with a geometric mean concentration of $0.63 \mu \mathrm{g} / \mathrm{g}$ (wet weight). Selenium concentrations in the blood of golden eagles ranged from 1.68 to $2.91 \mu \mathrm{g} / \mathrm{g}$ (dry weight) (Peltz and Waddell, 1991, p. 119, 189), with a geometric mean of $2.34 \mu \mathrm{g} / \mathrm{g}$. Selenium concentrations in blood from 16 golden eagles trapped near Cisco, Utah, during winter 1987 ranged 0.29 to $0.85 \mu \mathrm{g} / \mathrm{g}$ wet weight (R. DeWeese, U.S. Fish and Wildlife Service, unpublished data, 1989). Selenium concentrations in this study were within the range of concentrations found in golden eagles in east central Utah.

Mercury, another element of concern to fish-eating birds, was found in the blood of bald eagles in concentrations ranging from 0.92 to $5.09 \mu \mathrm{g} / \mathrm{g}$ (dry weight) (Peltz and Waddell, 1991, p. 118), with a geometric mean of $2.69 \mu \mathrm{g} / \mathrm{g}$. The maximum mercury concentration, $5.09 \mu \mathrm{g} / \mathrm{g}(1.07 \mu \mathrm{g} / \mathrm{g}$ wet weight), was less than geometric mean concentrations in bald eagles from the Pacific Northwest, except in nestlings (Wiemeyer and others, 1989).

The largest lead concentration in eagle blood was $0.87 \mu \mathrm{g} / \mathrm{g}(0.18 \mu \mathrm{g} / \mathrm{g}$ wet weight), which was less than the concentration $(>0.40 \mu \mathrm{g} / \mathrm{g}$ wet weight) that indicates significant recent exposure (Wiemeyer and others, 1989) and less than $0.26 \mu \mathrm{g} / \mathrm{g}$ (wet weight) found in blood of golden eagles in California (Pattee and others, 1990). Less than $0.20 \mu \mathrm{g} / \mathrm{g}$ (wet weight) was considered background concentration.

Arsenic concentration was less than reporting levels in all 18 samples analyzed. Reporting levels of arsenic were $0.2 \mu \mathrm{g} / \mathrm{g}$ dry weight for all but two samples, which were as large as $1 \mu \mathrm{g} / \mathrm{g}$ dry weight because of the small quantity of blood available. 
Table 40. Geometric mean concentrations of selected trace elements in blood of bald and golden eagles from areas near Pelican Lake and Ouray National Wildlife Refuge

[Mean moisture content is an arithmetic mean; $\mu \mathrm{g} / \mathrm{g}$, micrograms per gram dry weight; number in parentheses is number of samples analyzed]

\begin{tabular}{lcllc}
\hline \multicolumn{1}{c}{ Species } & $\begin{array}{c}\text { Mean } \\
\text { moisture } \\
\text { content } \\
(\text { percent })\end{array}$ & $\begin{array}{l}\text { Boron } \\
(\mu \mathrm{g} / \mathrm{g})\end{array}$ & $\begin{array}{c}\text { Mercury } \\
(\mu \mathrm{g} / \mathrm{g})\end{array}$ & $\begin{array}{c}\text { Selenium } \\
(\mu \mathrm{g} / \mathrm{g})\end{array}$ \\
\cline { 3 - 5 } Bald eagle & $(10) 80.1$ & (4) 5.7 & (10) 2.69 & (10) 3.26 \\
Golden eagle & $(9) 80.2$ & (8) 3.7 & (9) 0.06 & (9) 2.34 \\
\hline
\end{tabular}

\section{HYDROLOGY AND CONTAMINANTS IN BIOTA IN PLEASANT VALLEY AND PARIETTE WETLANDS}

\section{Hydrology and Water Quality}

Water diverted from the Duchesne River is delivered to the Pleasant Valley area by the Pleasant Valley Canal and distributed throughout the valley by several canals. Tailwater and other surface runoff is discharged to Pleasant Valley Wash, which then enters Pariette Draw and flows through Pariette Wetlands to the Green River (fig. 9). Water samples were collected from the Pleasant Valley Canal and Upper Pleasant Valley Canal (representing inflow to the valley), five U.S. Bureau of Reclamation observation wells in Pleasant Valley, the only operational U.S. Bureau of Reclamation drain, two sites in Pleasant Valley Wash, and seven ponds in Pariette Wetlands.

Water entering Pleasant Valley met all Utah standards for water for agricultural and wildlife use (table 41). The boron concentration in the water was $370 \mu \mathrm{g} / \mathrm{L}$, and the selenium concentration was less than the reporting limit of $1 \mu \mathrm{g} / \mathrm{L}$. Within $3 \mathrm{mi}$ of where water enters the valley, water in Pleasant Valley Wash at location 1 contained a selenium concentration of $4 \mu \mathrm{g} / \mathrm{L}$ (boron concentration was not measured). Water in the wash at location 2, 5 miles downstream, contained a selenium concentration of $6 \mu \mathrm{g} / \mathrm{L}$ and a boron concentration of $1,100 \mu \mathrm{g} / \mathrm{L}$. The deterioration in water quality was believed to be due to the discharge of tailwater from irrigation returns upstream in Pleasant Valley and accrual of ground water into the wash.

Water from four of the five observation wells contained large to extremely large concentrations of evaporite salts, nitrogen, and several metals (table 41). The wells were pumped dry two days before collecting water samples for analysis. The observation wells ranged in depth from 9.5 to $15 \mathrm{ft}$, and all but $\mathrm{OH} 148$ were cased with perforated, galvanized steel. Well $\mathrm{OH} 148$ was cased with slotted polyvinyl chloride. The effect of the galvanized casing was evident from the zinc concentrations that were as large as $15,000 \mu \mathrm{g} / \mathrm{L}$ in water from all wells except $\mathrm{OH} 148$. On December 1,1988 , water from well $\mathrm{OH} 148$ contained concentrations of $17 \mathrm{mg} / \mathrm{L}$ of nitrite plus nitrate, $29,000 \mu \mathrm{g} / \mathrm{L}$ boron, $840 \mu \mathrm{g} / \mathrm{L}$ selenium, and $42,000 \mathrm{mg} / \mathrm{L}$ dissolved solids. The well was resampled after 6 months, and the boron concentration declined to $11,000 \mu \mathrm{g} / \mathrm{L}$ while selenium concentration declined to $14 \mu \mathrm{g} / \mathrm{L}$. Boron concentrations ranged from 500 to $2,400 \mu \mathrm{g} / \mathrm{L}$ and selenium from 1 to $11 \mu \mathrm{g} / \mathrm{L}$ in the other four wells.

The U.S. Geological Survey operated three gaging stations in Pariette Wetlands from 1975 to 1982 , and two stations from 1975 to 1984 . Virtually all the water entering Pariette Wetlands was derived from irrigation tailwater, surplus irrigation water, and ground-water seepage from the 
Pleasant Valley area. The mean discharge for water years 1975 through 1984 at gage 09307200 near the flood control pond was $27.6 \mathrm{ft}^{3} / \mathrm{s}$. The mean discharge from Pariette Wetlands at gage 09307300 downstream of Redhead Pond was $22.8 \mathrm{ft}^{3} / \mathrm{s}$. This discharge suggests that there were evaporative and possible seepage losses of water from the ponds and little accrual.

The analysis of water samples from the gaging sites was limited to major ions, suspended sediment, and boron and indicated the water was a sodium sulfate type and very hard (hardness often greater than $500 \mathrm{mg} / \mathrm{L}$ ). Concentrations of nitrite plus nitrate in water from all stations commonly exceeded the Utah criterion of $4 \mathrm{mg} / \mathrm{L}$ for nitrate as a pollution indicator. The series of flow-through ponds in Pariette Wetlands were effective in removing suspended sediment. Median concentrations of suspended sediment declined from $469 \mathrm{mg} / \mathrm{L}$ at the station near the flood control pond to $311 \mathrm{mg} / \mathrm{L} \mathrm{at}$

Table 41. Discharge and selected water-quality properties and constituents deter-

$[\mu \mathrm{S} / \mathrm{cm}$, microsiemens per centimeter at 25 degrees Celsius; $\mathrm{mg} / \mathrm{L}$, milligrams

\begin{tabular}{|c|c|c|c|c|c|c|c|c|c|c|c|c|c|}
\hline Station name & Date & $\begin{array}{l}\text { Dis- } \\
\text { charge, } \\
\text { instan- } \\
\text { taneous, } \\
\text { cubic } \\
\text { feet per } \\
\text { second }\end{array}$ & $\begin{array}{l}\text { Spe- } \\
\text { cific } \\
\text { con- } \\
\text { duct- } \\
\text { ance } \\
\text { (mS/cm) }\end{array}$ & $\begin{array}{l}\mathrm{pH} \\
\text { (stand- } \\
\text { ard } \\
\text { units) }\end{array}$ & $\begin{array}{l}\text { Solids, } \\
\text { residue } \\
\text { at } 180 \\
{ }^{\circ} \mathrm{C} \text {, } \\
\text { dis- } \\
\text { solved } \\
\text { (mg/L) }\end{array}$ & $\begin{array}{c}\text { Alka- } \\
\text { linity, } \\
\text { lab } \\
(\mathrm{mg} / \mathrm{L} \\
\text { as } \\
\left.\mathrm{CaCO}_{3}\right)\end{array}$ & $\begin{array}{l}\text { Calcium, } \\
\text { dis- } \\
\text { solved } \\
\text { (mg/L } \\
\text { as } \mathrm{Ca} \text { ) }\end{array}$ & $\begin{array}{l}\text { Magne- } \\
\text { sium, } \\
\text { dis- } \\
\text { solved } \\
(\mathrm{mg} / \mathrm{L} \\
\text { as } \mathrm{Mg})\end{array}$ & $\begin{array}{l}\text { Sodium, } \\
\text { dis- } \\
\text { solved } \\
\text { (mg/h } \\
\text { as } \mathrm{Na})\end{array}$ & $\begin{array}{l}\text { Potas- } \\
\text { sium, } \\
\text { dis- } \\
\text { solved } \\
(\mathrm{mg} / \mathrm{L} \\
\text { as K) }\end{array}$ & $\begin{array}{l}\text { Chlo- } \\
\text { ride, } \\
\text { dis- } \\
\text { solved } \\
\text { (mg/L } \\
\text { as Cl) }\end{array}$ & $\begin{array}{c}\text { Sulfate, } \\
\text { dis- } \\
\text { solved s } \\
\text { (mg/L } \\
\text { as SO }\end{array}$ & $\begin{array}{l}\text { Fluo- } \\
\text { ride, } \\
\text { dis- } \\
\text { solved } \\
\text { (mg/l } \\
\text { as F) }\end{array}$ \\
\hline Pleasant Valley Canal at flume near Myton & $08-25-88$ & 81 & 820 & - & - & 250 & 53 & 36 & 64 & 1.8 & 18 & 130 & 0.3 \\
\hline Upper Pleasant Valley Canal & $08-25-88$ & - & 7,390 & - & - & - & - & - & - & - & - & - & - \\
\hline $\mathrm{OH} 51$ well & $12-01-88$ & - & 990 & 7.8 & 610 & 342 & 87 & 24 & 98 & 1.5 & 29 & 150 & - \\
\hline OH 56 well & $12-01-88$ & - & 4,350 & 7.6 & 3,130 & 360 & 180 & 85 & 630 & 1.4 & 400 & 1,400 & - \\
\hline $\mathrm{OH} 83$ well & $12-01-88$ & - & 6,450 & 7.5 & 5,890 & 399 & 370 & 290 & 810 & 5.1 & 270 & 3,400 & - \\
\hline $\mathrm{OH} 139$ well & $12-01-88$ & - & 3,200 & 6.6 & 2,980 & 376 & 520 & 95 & 140 & 1.2 & 25 & 1,700 & - \\
\hline $\mathrm{OH} 148$ well & $12-01-88$ & - & 50,000 & 8.0 & 42,000 & 482 & 440 & 210 & 11,000 & 9.1 & 2,300 & 25,000 & - \\
\hline $\mathrm{OH} 148$ well & $06-15-89$ & - & 16,100 & 7.5 & - & - & - & - & - & - & - & - & - \\
\hline Pleasant Valley farm drain & $06-13-89$ & - & 2,470 & 7.2 & - & - & - & - & - & - & - & - & - \\
\hline Pleasant Valley Wash at location 1 & $08-25-88$ & 4.3 & 1,740 & - & - & - & - & - & - & - & - & - & - \\
\hline Pleasant Valley Wash at location 2 & $08-25-88$ & 13 & 2,650 & - & - & 240 & 150 & 80 & 430 & 2.8 & 66 & 1,300 & .5 \\
\hline Flood control pond at outlet & $09-01-88$ & 5.8 & 2,630 & 8.3 & - & - & - & - & - & - & - & - & - \\
\hline Desiltation pond outlet & $04-13-87$ & - & - & - & - & - & - & - & - & - & - & - & - \\
\hline Desiltation pond outlet & $08-19-87$ & 35 & - & 8.3 & - & 212 & 90 & 46 & 220 & 2.8 & 39 & 590 & .5 \\
\hline Desiltation pond outlet & $08-25-88$ & - & 2,450 & - & - & - & - & - & - & - & - & - & - \\
\hline Small Island Pond outflow & $09-01-88$ & - & 2,630 & 8.0 & - & - & - & - & - & - & - & - & - \\
\hline Big Island Pond & $04-13-87$ & - & - & - & - & - & - & - & - & - & - & - & - \\
\hline Big Island Pond & $08-19-87$ & - & - & 8.5 & - & - & - & - & - & - & - & - & - \\
\hline Big Island Pond & $09-01-88$ & - & 3,610 & 8.8 & - & - & - & - & - & - & - & - & - \\
\hline Shoveler Pond & $08-19-87$ & - & - & 9.3 & - & - & - & - & - & - & - & - & - \\
\hline Gadwall Pond near middle outlet & $04-13-87$ & - & - & - & - & - & - & - & - & - & - & - & - \\
\hline Gadwall Pond near middle outlet & $08-19-87$ & - & - & 8.3 & - & - & - & - & - & - & - & - & - \\
\hline Gadwall Pond near middle outlet & $09-01-88$ & - & 2,770 & 8.4 & - & - & - & - & - & - & - & - & - \\
\hline Pariette Draw at mouth & $08-19-87$ & 49 & - & - & - & 209 & 90 & 49 & 260 & 3.2 & 51 & 630 & .5 \\
\hline Pariette Draw at mouth & $09-01-88$ & - & 2,550 & 8.3 & - & - & - & - & - & - & - & - & - \\
\hline
\end{tabular}


the station downstream of the desiltation pond to $160 \mathrm{mg} / \mathrm{L}$ at the station downstream of Redhead Pond. The decline in concentrations resulted in a reduction in the median load of suspended sediment discharged to the Green River from 21 to 7.2 tons per day.

Boron concentrations in water entering Pariette Wetlands 2.5 mi upstream of the desiltation pond and leaving the draw from Redhead Pond consistently were larger than the Utah agricultural standard of $750 \mu \mathrm{g} / \mathrm{L}$, with median concentrations of $1,200 \mu \mathrm{g} / \mathrm{L}$ or greater at both sites. The median boron concentration of $1,300 \mu \mathrm{g} / \mathrm{L}$ in water leaving Pariette Wetlands statistically was larger (MannWhitney test, ALS 0.01 ) than the median concentration of $1,200 \mu \mathrm{g} / \mathrm{L}$ measured entering the draw

mined for water flowing into Pleasant Valley and Pariette Wetlands during 1987-89.

per liter; $\mu \mathrm{g} / \mathrm{L}$, micrograms per liter; -, no data available; <, less than]

\begin{tabular}{|c|c|c|c|c|c|c|c|c|c|c|c|c|c|c|c|}
\hline $\begin{array}{l}\text { Silica, } \\
\text { dis- } \\
\text { solved } \\
(\mathrm{mg} / \mathrm{L} \\
\text { as } \\
\left.\mathrm{SiO}_{2}\right)\end{array}$ & $\begin{array}{c}\text { Nitro- } \\
\text { gen, } \\
\mathrm{NO}_{2}+\mathrm{NO}_{3} \\
\text { dis- } \\
\text { solved } \\
\text { (mg/L } \\
\text { as } \mathrm{N} \text { ) }\end{array}$ & $\begin{array}{l}\text { Arsenic, } \\
\text { dis- } \\
\text { solved } \\
\text { (mg/L } \\
\text { as As) }\end{array}$ & $\begin{array}{c}\text { Barium, } \\
\text { dis- } \\
\text { solved } \\
\text { (mg/L } \\
\text { as } \mathrm{Ba} \text { ) }\end{array}$ & $\begin{array}{l}\text { Boron, } \\
\text { dis- } \\
\text { solved } \\
\text { (mg/L } \\
\text { as B) }\end{array}$ & $\begin{array}{l}\text { Cadmium, } \\
\text { dis- } \\
\text { solved } \\
\text { (mg/L } \\
\text { as Cd) }\end{array}$ & $\begin{array}{l}\text { Chro- } \\
\text { mium, } \\
\text { dis- } \\
\text { solved } \\
\text { (mg/L } \\
\text { as Cr) }\end{array}$ & $\begin{array}{c}\text { Copper, } \\
\text { dis- } \\
\text { solved } \\
\text { (mg/L } \\
\text { as Cu) }\end{array}$ & $\begin{array}{l}\text { Lead, } \\
\text { dis- } \\
\text { solved } \\
\text { (mg/L } \\
\text { as Pb) }\end{array}$ & $\begin{array}{c}\text { Mercury, } \\
\text { dis- } \\
\text { solved } \\
\text { (mg/L } \\
\text { as } \mathrm{Hg})\end{array}$ & $\begin{array}{l}\text { Molyb- } \\
\text { denum, } \\
\text { dis- } \\
\text { solved } \\
\text { (mg/h } \\
\text { as Mo) }\end{array}$ & $\begin{array}{l}\text { Nickel, } \\
\text { dis- } \\
\text { solved } \\
\text { (mg/L } \\
\text { as Ni) }\end{array}$ & $\begin{array}{l}\text { Sele- } \\
\text { nium, } \\
\text { dis- } \\
\text { solved } \\
(\mathrm{mg} / \mathrm{h} \\
\text { as } \mathrm{Se})\end{array}$ & $\begin{array}{l}\text { Silver, } \\
\text { dis- } \\
\text { solved } \\
\text { (mg/L } \\
\text { as Ag) }\end{array}$ & $\begin{array}{l}\text { Vana- } \\
\text { dium, } \\
\text { dis- } \\
\text { solved } \\
\text { (mg/L } \\
\text { as V) }\end{array}$ & $\begin{array}{l}\text { Zinc, } \\
\text { dis- } \\
\text { solved } \\
\text { (mg/L } \\
\text { as Zn) }\end{array}$ \\
\hline 11 & - & 4 & 83 & 370 & $<1.0$ & $<1$ & $<10$ & $<5$ & $<0.1$ & 3 & 3 & $<1$ & 4.0 & 1 & 5 \\
\hline- & - & - & - & - & - & - & - & - & - & - & - & $<1$ & - & - & - \\
\hline- & 0.880 & $<1$ & - & 500 & 4.0 & 2 & 2 & $<5$ & $<.1$ & 8 & - & 3 & - & $<1$ & 2,200 \\
\hline- & .500 & $<1$ & - & 1,500 & $<1.0$ & 2 & 5 & $<5$ & $<.1$ & 8 & - & 11 & - & 7 & 2,800 \\
\hline- & $<.100$ & 4 & - & 2,400 & $<1.0$ & 3 & 2 & $<5$ & .1 & 20 & - & 1 & - & 6 & 2,300 \\
\hline- & .870 & $<1$ & - & 870 & $<1.0$ & 4 & 3 & $<5$ & $<.1$ & 14 & - & 4 & - & 2 & 15,000 \\
\hline- & 17.0 & 8 & -2 & 29,000 & 2.0 & $<4$ & 16 & $<5$ & $<.1$ & 1.100 & - & 840 & - & 70 & 1,000 \\
\hline- & - & - & -1 & 11,000 & - & - & - & - & - & - & - & 14 & - & - & - \\
\hline- & - & - & - & - & - & - & - & - & - & - & - & 9 & - & - & - \\
\hline- & - & - & - & - & - & - & - & - & - & - & - & 4 & - & - & - \\
\hline 13 & - & 5 & 100 & 1,100 & $<1.0$ & $<1$ & 10 & $<5$ & $<.1$ & 12 & 3 & 6 & $<1.0$ & 3 & $<10$ \\
\hline- & - & 1 & $<100$ & 1,000 & 2.0 & $<1$ & $<10$ & $<5$ & $<.1$ & 16 & $<1$ & 5 & 2.0 & 4 & $<10$ \\
\hline- & - & - & - & 770 & - & - & - & - & - & - & - & 6 & - & - & 10 \\
\hline 10 & - & 5 & 110 & 690 & $<1.0$ & 10 & $<10$ & $<5$ & .1 & 10 & $<1$ & 3 & $<1.0$ & 5 & 17 \\
\hline- & - & - & - & - & - & - & - & - & - & - & - & 5 & - & - & - \\
\hline- & - & 9 & 200 & 1,200 & 2.0 & $<1$ & $<10$ & $<5$ & $<.1$ & 13 & $<1$ & 1 & 1.0 & 3 & $<10$ \\
\hline- & - & - & - & 1,500 & - & - & - & - & - & - & - & 5 & - & - & 20 \\
\hline- & - & - & - & 860 & - & - & - & - & - & - & - & 3 & - & - & 10 \\
\hline- & - & 3 & 100 & 1,700 & 2.0 & $<1$ & $<10$ & $<5$ & $<.1$ & 33 & $<1$ & 2 & 1.0 & 11 & $<10$ \\
\hline- & - & - & - & 2,300 & - & - & - & - & - & - & - & 2 & - & - & $<10$ \\
\hline- & - & - & - & 1,300 & - & - & - & - & - & - & - & 7 & - & - & 20 \\
\hline- & - & - & - & 790 & - & - & - & - & - & - & - & 4 & - & - & $<10$ \\
\hline- & - & 5 & 100 & 1,200 & 2.0 & 1 & 10 & $<5$ & $<.1$ & 16 & 1 & 3 & 1.0 & 4 & $<10$ \\
\hline 9.5 & - & 6 & 110 & 800 & $<1.0$ & $<10$ & $<10$ & $<5$ & .2 & 11 & $<1$ & 1 & $<1.0$ & 6 & 5 \\
\hline- & - & 5 & $<100$ & 1,100 & 2.0 & $<1$ & $<10$ & $<5$ & $<.1$ & 12 & 1 & 2 & 1.0 & 3 & $<10$ \\
\hline
\end{tabular}


during water years $1975-84$. This relation suggests that considerable evaporative concentration occurs in the ponds and/or that boron is leached from soils within Pariette Wetlands.

A limited number of analyses for trace elements in water from sites in Pariette Wetlands and the Green River were done by a private contract lab for the Bureau of Land Management in 1978-79. Boron concentrations in the samples generally were greater than the State agricultural standard of $750 \mu \mathrm{g} / \mathrm{L}$, dissolved-solids concentration often exceeded $2,000 \mathrm{mg} / \mathrm{L}$, and selenium was present in large concentrations in several samples. The analytical method used to determine selenium concentration was not specified, but it is unlikely the samples received an oxidation-reduction digestion prior to analysis and, therefore, could represent a conservative estimate of the selenium concentration:

Location

Pariette Draw near flood control dam

Pariette Draw at desiltation pond

Pariette Draw at East Dike

Pariette Draw at Redhead Pond

Green River above Pariette Draw
Selenium concentration

$(\mu \mathrm{g} / \mathrm{L})$
$<1$

8

15

298

6 and 19

Water samples taken in Pariette Wetlands during 1987-89 indicate that only concentrations of boron and selenium exceeded applicable State water-quality standards (table 41) and could adversely affect waterfowl and fish. Boron concentrations in the ponds consistently exceeded the standard for agricultural use.

Selenium concentrations in ponds in Pariette Wetlands were variable, ranging from 1 to $7 \mu \mathrm{g} / \mathrm{L}$, and tended to be larger in samples taken in spring than in fall. The only pond where the median selenium concentration was near or exceeded the Utah standard of $5 \mu \mathrm{g} / \mathrm{L}$ for wildlife protection was the desiltation pond. The largest concentration $(7 \mu \mathrm{g} / \mathrm{L})$ was present in Gadwall Pond. Concentrations did not show any trend with distance downstream from the desiltation pond to Gadwall Pond but were small at the discharge from Redhead Pond, the last impoundment prior to release to the Green River.

Because the source of water used to maintain Pariette Wetlands is Pleasant Valley, any changes in volume or quality of water in the valley would affect Pariette Wetlands. The addition of ground-water drains in some sections of Pleasant Valley could result in drainwater containing large concentrations of evaporite minerals, selenium, and boron.

\section{Trace Elements in Bottom Sediment}

Concentrations of most elements in bottom sediment from two ponds at Pariette Wetlands were within a typical range observed for soils in the area (table 42). Selenium concentrations of 1.5 and $0.4 \mu \mathrm{g} / \mathrm{g}$ in Redhead Pond and the desiltation pond were at least an order of magnitude larger than typically found in soils. The concentrations, while larger than background values, were much less than concentrations in selenium-contaminated sediment from Stewart Lake WMA and Ouray NWR. Aluminum concentrations in bottom sediment from the ponds at Pariette Wetlands were slightly larger than concentrations found in soils near the area. Boron was not determined in the samples.

A single sample of surface-salt efflorescence was collected from the dry bed of Pintail Pond in April 1987. The sample consisted primarily of sodium sulfate and chloride but also contained $1,674 \mu \mathrm{g} / \mathrm{g}$ of boron and $1.4 \mu \mathrm{g} / \mathrm{g}$ of selenium. 
Table 42. Concentrations of elements and radionuclides in the less than 62-micron fraction of sediment samples collected from Redhead Pond and the desiltation pond at Pariette Wetlands related to the 95-percent confidence interval for soil in the Piceance Basin, Colorado, and the Uinta Basin, Utah

[Concentrations are for total extractable forms except for boron, which is hot water extractable and is 10-80 percent of the total extractable. The Piceance Basin is in Colorado, 80 miles southeast of the study area. Data from the Piceance and Uinta Basins from Tidball and Severson (1982); -, no data available; <, less than]

\begin{tabular}{|c|c|c|c|}
\hline \multirow[b]{2}{*}{ Constituent } & \multicolumn{2}{|c|}{ Pariette Wetlands } & \multirow[b]{2}{*}{$\begin{array}{l}\text { Soil in the Piceance } \\
\text { and Unita Basins }\end{array}$} \\
\hline & $\begin{array}{l}\text { Redhead } \\
\text { Pond }\end{array}$ & $\begin{array}{l}\text { Desiltation } \\
\text { pond }\end{array}$ & \\
\hline \multicolumn{4}{|c|}{ Concentration, in micrograms per gram } \\
\hline Arsenic & 11 & 5.4 & $3.5-25$ \\
\hline Barium & 950 & 940 & $640-2,250$ \\
\hline Beryllium & 1 & 1 & $1.1-5.3$ \\
\hline Bismuth & $<10$ & $<10$ & - \\
\hline Cadmium & $<2$ & $<2$ & - \\
\hline Cerium & 55 & 54 & $25-110$ \\
\hline Chromium & 51 & 46 & $27-94$ \\
\hline Cobalt & 9 & 9 & $4.4-12$ \\
\hline Copper & 19 & 18 & $9.5-95$ \\
\hline Europium & $<2$ & $<2$ & - \\
\hline Gallium & 15 & 14 & $8.6-26$ \\
\hline Gold & $<8$ & $<8$ & - \\
\hline Holmium & $<4$ & $<4$ & - \\
\hline Lanthanum & 32 & 32 & $29-52$ \\
\hline Lead & 16 & 15 & $4.5-32$ \\
\hline Lithium & 34 & 33 & $14-100$ \\
\hline Manganese & 380 & 400 & - \\
\hline Molybdenum & $<2$ & $<2$ & $2.7-12$ \\
\hline Neodymium & 24 & 25 & - \\
\hline Nickel & 16 & 17 & $9.9-40$ \\
\hline Niobium & 5 & 7 & - \\
\hline Scandium & 8 & 7 & $5.5-11$ \\
\hline Selenium & 1.5 & .4 & $.01-.058$ \\
\hline Silver & $<2$ & $<2$ & - \\
\hline Strontium & 530 & 510 & $190-740$ \\
\hline Tantalum & $<40$ & $<40$ & - \\
\hline Thorium & 8 & 8 & $5.5-16$ \\
\hline Tin & $<10$ & $<10$ & - \\
\hline Uranium & $<100$ & $<100$ & $2.4-5.2$ \\
\hline Vanadium & 53 & 50 & $40-120$ \\
\hline Ytterbium & 1 & 1 & $1.4-4.6$ \\
\hline Yttrium & 13 & 13 & $11-29$ \\
\hline Zinc & 47 & 43 & $33-110$ \\
\hline \multicolumn{4}{|c|}{ Concentration, in weight percent } \\
\hline Aluminum & 6.6 & 6.5 & $3.4-5.8$ \\
\hline Calcium & 3.6 & 3.4 & $.001-11$ \\
\hline Iron & 2.0 & 1.9 & $1-3$ \\
\hline Magnesium & .98 & .88 & $.45-3.9$ \\
\hline Phosphorus & .09 & .08 & - \\
\hline Potassium & 2.0 & 1.9 & $1.2-3$ \\
\hline Sodium & 2.0 & 2.0 & $.14-2.1$ \\
\hline Titanium & .21 & .2 & $.21-.33$ \\
\hline
\end{tabular}




\section{Association of Selenium with Soil Type in the Pleasant Valley and Pariette Draw Area}

Soils in Pleasant Valley and Pariette Draw are similar in origin to those near Ouray: quaternary gravel and alluvial deposits. Water was sampled from five shallow wells (less than $15 \mathrm{ft}$ ) and one subsurface drain installed by the U.S. Bureau of Reclamation in the Pleasant Valley area. These ground-water sites were in three of the five principle soil associations in the area described by Wilson and others (1959). Selenium concentrations in four wells in Avalon fine sandy loam were 1, 3, 4 , and $11 \mu \mathrm{g} / \mathrm{L}$. Avalon fine sandy loam is derived from quartzite and mixed sedimentary rocks, mainly pale brown sandstone and shale. Selenium concentrations in a well in Pariette clay loam were 840 and $14 \mu \mathrm{g} / \mathrm{L}$ for samples taken in 1988 and 1989. Pariette clay loam is derived from varicolored clay shale transported from nearby areas or from the underlying clay shale of the Duchesne River Formation. The depth to the underlying shale ranges from 18 to 36 in. and the bedrock contains considerable quantities of dissolved salts (Wilson and others, 1959, p. 35). Because the Duchesne River Formation is considered to be seleniferous in areas (Rosenfeld and Beath, 1964, p. 26), soils of Pariette clay loam derived from it may provide the source of selenium in soils in Pleasant Valley.

The selenium concentration in water from a single subsurface drain was $9 \mu \mathrm{g} / \mathrm{L}$. The farm drain was in a soil association described as "rough hilly land" by Wilson and others (1959) with a soil type consisting of shallow soils overlying sandstone or shale bedrock.

\section{Biological Observations and Contamination in Biota}

Selenium concentrations in American coot eggs and the water supply sources were examined to determine whether biological data from Pariette Wetlands should be evaluated as a single unit or by subunit pond grouping. On the basis of concentrations of selenium in American coot eggs (fig. 55), boron in several types of biological samples, and the physical location of individual ponds within the drainage, it was determined to divide the area into four subunits.

Contamination in Pariette Wetlands appeared to result from elevated concentrations of selenium and boron in biological samples. Selenium concentrations in random eggs ranged as large as $16.9 \mu \mathrm{g} / \mathrm{g}$ in a pied-billed grebe egg and in whole-body fish ranged as large as $16.9 \mu \mathrm{g} / \mathrm{g}$ in a sample of common carp. Both of these values exceed values considered to be associated with reproductive problems, but no deformed embryos were found in bird eggs.

Concentrations of boron found in livers of immature American coots ranged from 2 to $4 \mu \mathrm{g} / \mathrm{g}$ (dry weight) and were similar to concentrations found in mallard ducklings fed diets containing boron concentrations ( 35 to $439 \mu \mathrm{g} / \mathrm{g}$, dry weight) known to affect growth adversely (Smith and Anders, 1989; Hoffman and others, 1990). Plants such as potomogeton and green algae from Pariette Wetlands contained boron concentrations ranging from 9.8 to 2,130 (dry weight). These concentrations are similar to or larger than concentrations reported to affect duckling growth adversely. Concentrations of boron in invertebrates (as large as $33.6 \mu \mathrm{g} / \mathrm{g}$ ) were less than $35 \mu \mathrm{g} / \mathrm{g}$ but were sufficiently large to be of concern.

Substantial effort to document use of individual ponds by waterbirds was not undertaken at Pariette Wetlands. Observations for specific ponds were not collected routinely and, as a result, data are generally inadequate to plot seasonal use of ponds or groups of ponds. Species observed using Pariette Wetlands during the surveys are listed in table 10. Waterfowl use of the area and production has been documented by the USBLM since 1978 (fig. 56). These data are presented but should be used only as indicators of potential productivity and not as a precise indicator of actual production. No detailed study has been conducted to estimate production for each pond. 


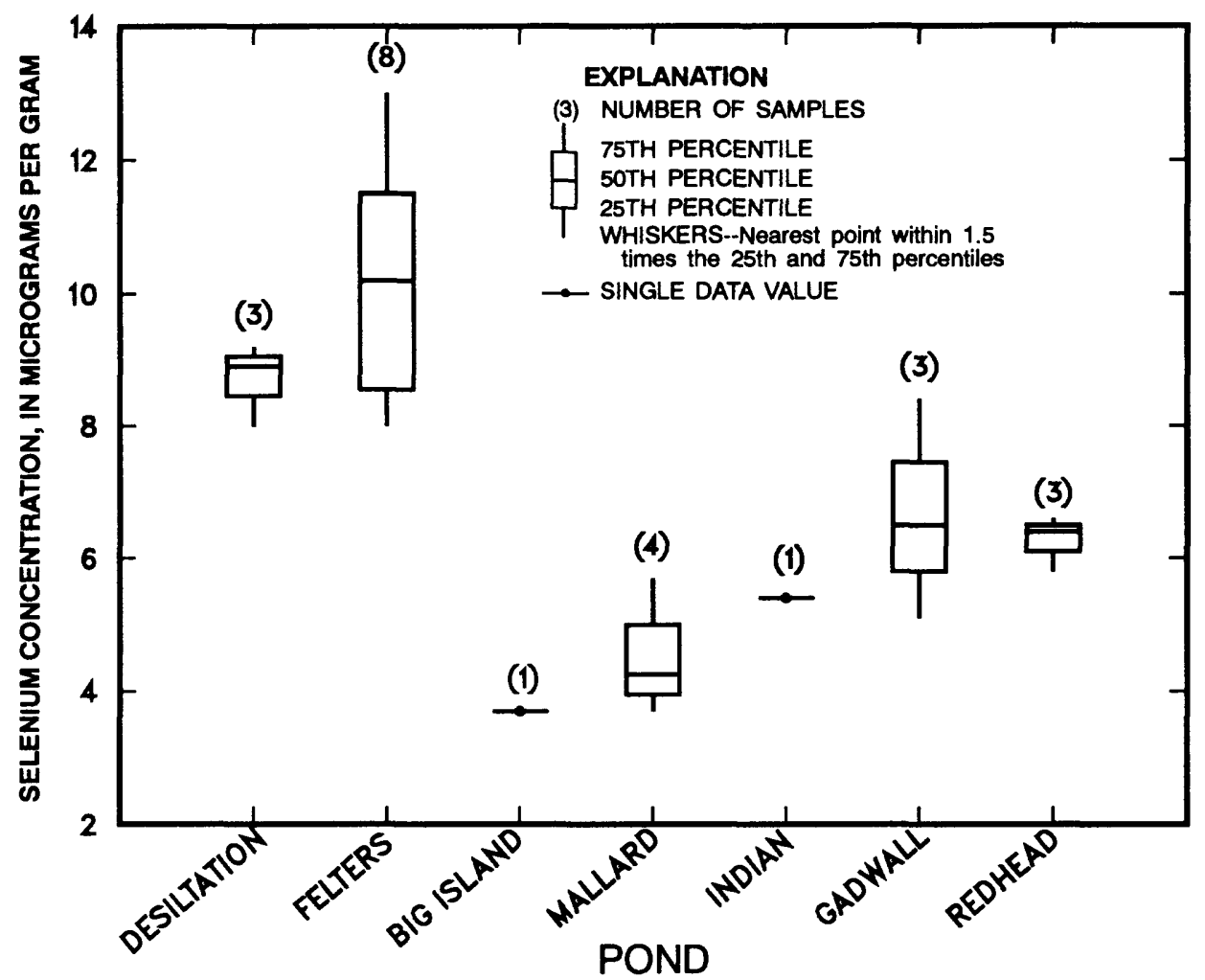

Figure 55. Selenium concentrations in American coot eggs from ponds in Pariette Wetlands, 1989.

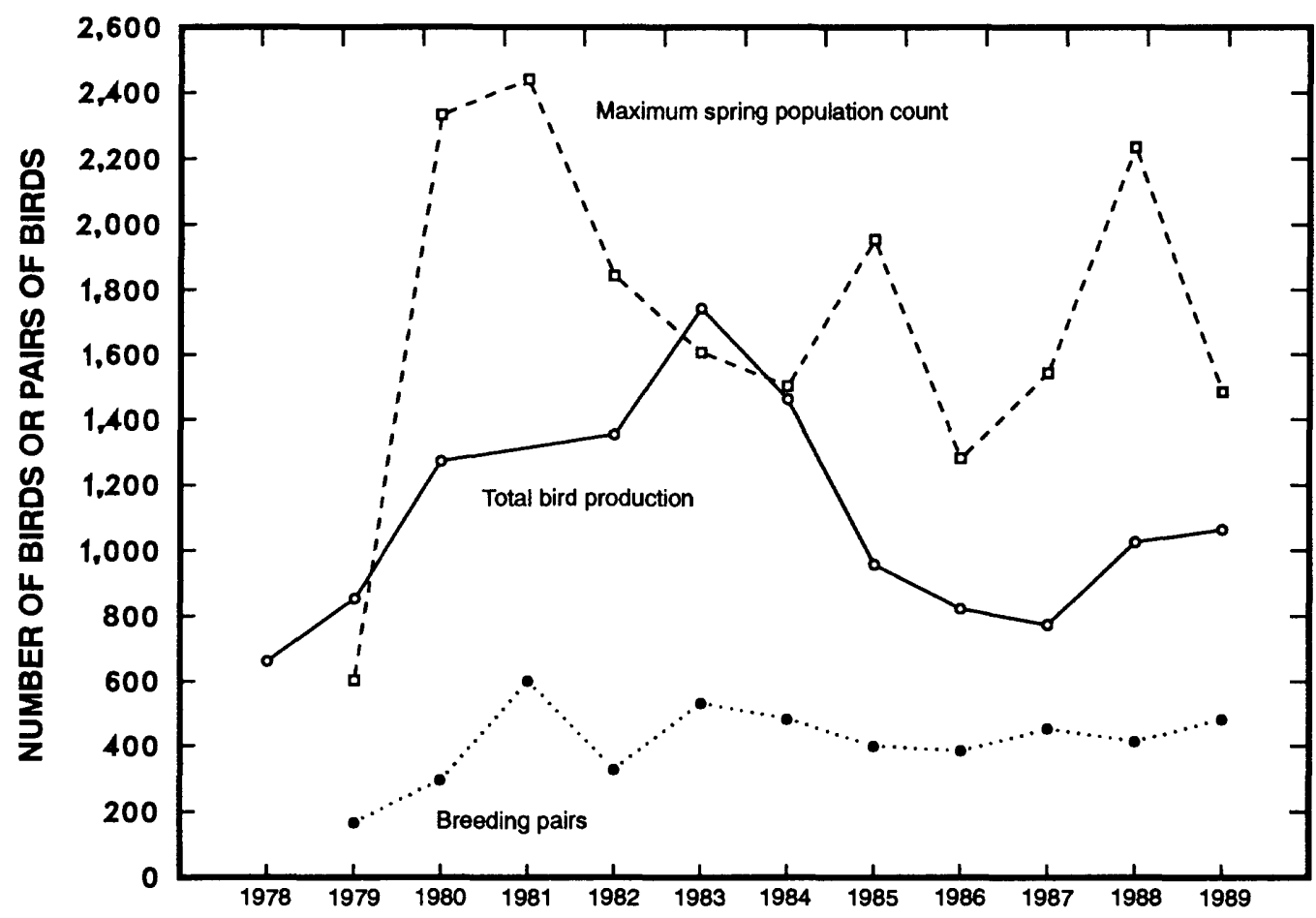

Figure 56. Maximum spring population count, total bird production, and number of breeding pairs of waterfowl at Pariette Wetlands, 1978-89. 


\section{Unit 1 - Pariette Wetlands}

Unit 1 consisted of the following ponds or areas (fig. 9): flood control, desiltation, North Felters, Felters, and Big Wash. These sites are near the upstream part of the wetland complex on the main stem of Pariette Draw.

\section{Nesting observations}

Nesting studies were done in 1987 and 1989. They consisted of searches for occupied nests and observation of bird use of nests. The primary emphasis was on American coot and pied-billed grebe in 1987. In 1989, the emphasis was expanded to all waterbirds using the ponds.

A total of 2 American coot nests were monitored at the desiltation pond and 19 at Felters Pond. Overall, 38 percent of American coot nests monitored in Unit 1 through completion of incubation were successful in hatching at least one egg. One of two nests in the desiltation pond followed through completion was lost to predators. Nests at Felters Pond appeared to be very susceptible to mammalian predation. Of nests that were successful, none had unhatched eggs. Of the random eggs collected, one contained contents that were rotten with no development apparent. Two pied-billed grebe nesting attempts were monitored at Felters Pond. One nest was successful (50 percent) and one nest was depredated.

One gadwall nest monitored in Big Wash Pond was believed to be abandoned because of heavy equipment operation near the nest. Four mallard nests were monitored near Felters Pond. Two of four mallard nests monitored near Felters Pond were successful, and two were lost to predation. One cinnamon teal nest monitored at Felters Pond was abandoned.

\section{Observations of waterbird use}

Surveys of waterfowl use and broods were conducted primarily by the Bureau of Land Management. Waterfowl production and spring population counts for Pariette Wetlands from 1978 through 1989 are shown in figure 56. Species observed during 1988 and 1989 by the authors during waterbird use counts for part of Unit 1 (flood control, Felters, and desiltation ponds are shown in table 18.

Studies conducted by the U.S. Bureau of Land Management for the Eagle Rock Unit (approximately the same areas as Felters Pond and Big Wash) indicate that broods of ducks counted varied from 7 in 1987, to 5 in 1988 , to 14 in 1989 , with average brood sizes of $4.4,5.8$, and 4.7, respectively. Counts of American coot broods increased from 2 in 1987 to 4 in 1989, with average brood sizes of 3 and 1.3, respectively. Counts for the Castle Peak Unit (approximately the same areas as the desiltation pond and flood control pond) indicate that broods of ducks counted varied from 5 in 1987, to 2 in 1988, to 14 in 1989, with average brood sizes of 3.2, 5.5, and 4.7, respectively (Tim Faircloth, U.S. Bureau of Land Management, oral commun., 1990).

\section{Residue in tissue}

Data from the ponds in Unit 1 were aggregated for analysis (table 43) and interpretation of data. When a range of values is cited, the values are for individual samples and data are from Peltz and Waddell (1991). A total of 11 eggs were collected randomly from American coot nests. Selenium concentrations (as dry weight) ranged from 8 to $13 \mu \mathrm{g} / \mathrm{g}$, with a geometric mean concentration of 9.7 $\mu \mathrm{g} / \mathrm{g}$. These concentrations are within the 8 to $10 \mu \mathrm{g} / \mathrm{g}$ range found to affect reproduction adversely in some species (Skorupa and Ohlendorf, 1991). The largest boron concentration in eggs in this unit was $5 \mu \mathrm{g} / \mathrm{g}$ at Felters Pond. Potamogeton from this pond contained a boron concentration of 2,130 $\mu \mathrm{g} / \mathrm{g}$. Under laboratory conditions, boron concentrations ranged from 5 to $21 \mu \mathrm{g} / \mathrm{g}$ in the eggs of mallards that were fed a diet containing about $300 \mu \mathrm{g} / \mathrm{g}$ boron (Smith and Anders, 1989); however, these concentrations were not associated with reduced reproductive success. Diets containing as little boron as $35 \mu \mathrm{g} / \mathrm{g}$ dry weight may adversely affect growth rates in mallard ducklings (Smith and Anders, 1989). 
Table 43. Geometric mean selenium concentrations in biological samples collected from the flood control, desiltation, North Felters, and Felters Ponds, in Big Wash in Pariette Wetlands (Unit 1), and in fish samples collected nationwide by the National Contaminant Biomonitoring Program

[All eggs are random except those identified by NR, non-random; mm, millimeter; g, gram; $\mu \mathrm{g} / \mathrm{g}$, micrograms per gram (dry weight); - , not specified. NCBP, National Contaminant Biomonitoring Program, from Schmitt and Brumbaugh, 1990 (1984 geometric mean concentration, 85th percentile, converted to dry weight using 75 percent moisture). Weight of bird egg is mean weight of contents.

Mean length, weight, and moisture content are arithmetic means]

\begin{tabular}{lcccccc}
\hline Species & $\begin{array}{c}\text { Sample } \\
\text { size }\end{array}$ & $\begin{array}{c}\text { Sample } \\
\text { type }\end{array}$ & $\begin{array}{c}\text { Mean } \\
\text { length } \\
(\mathrm{mm})\end{array}$ & $\begin{array}{c}\text { Mean } \\
\text { weight } \\
(\mathrm{g})\end{array}$ & $\begin{array}{c}\text { Mean } \\
\text { moisture } \\
\text { content } \\
(\text { percent })\end{array}$ & $\begin{array}{c}\text { Geometric } \\
\text { mean selenium } \\
\text { concentration } \\
(\mu \mathrm{g} / \mathrm{g})\end{array}$
\end{tabular}

\begin{tabular}{|c|c|c|c|c|c|c|}
\hline \multicolumn{7}{|c|}{ Bird eggs } \\
\hline $\begin{array}{l}\text { American coot } \\
\text { Cinnamon teal } \\
\text { Gadwall (NR) } \\
\text { Mallard } \\
\text { Pied-billed grebe } \\
\text { Yellow-headed blackbird } \\
\text { All random eggs }\end{array}$ & $\begin{array}{r}11 \\
1 \\
1 \\
6 \\
1 \\
1 \\
20\end{array}$ & $\begin{array}{l}\text { Individual } \\
\text { Individual } \\
\text { Individual } \\
\text { Individual } \\
\text { Individual } \\
\text { Composite } \\
\text { Composite, Individual }\end{array}$ & $\begin{array}{l}50 \\
47 \\
54 \\
58 \\
46 \\
27 \\
-\end{array}$ & $\begin{array}{l}26 \\
27 \\
40 \\
41 \\
15 \\
12 \\
-\end{array}$ & $\begin{array}{l}75.3 \\
67.5 \\
68.6 \\
67.8 \\
76.2 \\
82.2 \\
73.0\end{array}$ & $\begin{array}{r}9.7 \\
9.6 \\
8.4 \\
9.8 \\
16.9 \\
11 \\
10.0\end{array}$ \\
\hline \multicolumn{7}{|c|}{ Bird tissue } \\
\hline \multicolumn{7}{|c|}{ Fish } \\
\hline Common carp & 15 & Composite & 169 & 272 & 78.5 & 10.9 \\
\hline Flannelmouth sucker & 4 & Composite & 381 & 523 & 75.6 & 8.4 \\
\hline Green sunfish & 2 & Composite, Individual & 126 & 58 & 73.3 & 6.1 \\
\hline All fish & 21 & Composite, Individual & - & - & 77.4 & 9.8 \\
\hline Fish, NCBP nationwide & - & - & - & - & 75.0 & 2.9 \\
\hline \multicolumn{7}{|c|}{ Plants } \\
\hline Chara & 2 & Composite & - & - & 77.7 & 1.5 \\
\hline Filamentous green algae & 3 & Composite & - & - & 81.0 & 2.2 \\
\hline Water milfoil & 1 & Composite & - & - & 84.7 & 1.38 \\
\hline Potamogeton & 3 & Composite & - & - & 84.7 & 3.3 \\
\hline Cattail & 3 & Composite & - & - & 85.0 & 0.8 \\
\hline $\begin{array}{l}\text { Horned pondweed } \\
\text { All non-emergent rooted }\end{array}$ & 1 & Composite & - & - & 87.9 & 4.89 \\
\hline aquatics, and Chara & 7 & Composite & - & - & 83.1 & 2.5 \\
\hline \multicolumn{7}{|c|}{ Invertebrates } \\
\hline Mixed invertebrates & 7 & Composite & - & - & 77.7 & 7.3 \\
\hline
\end{tabular}

Six mallard eggs randomly collected near Felters Pond contained selenium concentrations that ranged from 6 to $14.8 \mu \mathrm{g} / \mathrm{g}$, with a geometric mean concentration of $9.8 \mu \mathrm{g} / \mathrm{g}$. The largest selenium concentration in bird eggs in Unit 1 was $16.9 \mu \mathrm{g} / \mathrm{g}$ in a pied-billed grebe egg. A composite sample of yellow-headed blackbird eggs taken at Felters Pond had a concentration of $11 \mu \mathrm{g} / \mathrm{g}$. This sample was similar to the mean $(12.7 \mu \mathrm{g} / \mathrm{g})$ for yellow-headed blackbird eggs at the North Roadside Pond (table 34).

The livers of four American coots sampled during the summer to assess brood-rearing conditions had a geometric mean selenium concentration of $15.3 \mu \mathrm{g} / \mathrm{g}$. Two of these coots collected at 
the desiltation pond had a geometric mean selenium concentration of $20.3 \mu \mathrm{g} / \mathrm{g}$, and two collected at the North Felters Pond had a geometric mean concentration of $11.5 \mu \mathrm{g} / \mathrm{g}$. Selenium concentrations in livers of American coots collected at the desiltation pond were larger than values of coots collected at Stewart Lake (Stephens and others, 1988a) but were less than those collected at the Roadside Ponds at Ouray NWR. Concentrations approached those believed to be associated with selenium toxicity in American coots in this study at the North Roadside Pond and in captive-reared mallards with large quantities of selenium in their diets (Heinz and others, 1987).

Whole-body selenium concentrations in 21 samples of fish ranged from $4.8 \mu \mathrm{g} / \mathrm{g}$ in green sunfish from Felters Pond to $16.9 \mu \mathrm{g} / \mathrm{g}$ in common carp from the desiltation pond, with a geometric mean of $9.8 \mu \mathrm{g} / \mathrm{g}$. Six of the samples (29 percent), all common carp, exceeded the $12 \mu \mathrm{g} / \mathrm{g}$ level associated with reproductive failure (Lemly and Smith, 1987); however, reproductive problems were not evident in the carp population. Common carp had a geometric mean selenium concentration of 10.9 $\mu \mathrm{g} / \mathrm{g}$. Flannelmouth sucker and green sunfish had smaller geometric mean selenium concentrations of 8.4 and $6.1 \mu \mathrm{g} / \mathrm{g}$, respectively (table 43 ).

Plants analyzed from Unit 1 generally contained small selenium concentrations ranging from $0.39 \mu \mathrm{g} / \mathrm{g}$ in cattail at the desiltation pond to $15.3 \mu \mathrm{g} / \mathrm{g}$ in a sample of potamogeton from Felters Pond. All samples contained less than $5 \mu \mathrm{g} / \mathrm{g}$ selenium except for the potamogeton from Felters Pond. Samples, summarized by taxonomic group, are shown in table 43. Selenium concentrations in some genera appeared to be strongly influenced by season at other sites. At Felters Pond, a sample of potamogeton collected in June, about one month after the sample containing $15.3 \mu \mathrm{g} / \mathrm{g}$ of selenium was collected, contained only $1.40 \mathrm{\mu g} / \mathrm{g}$ of selenium. The sample collected in May consisted of overwintered plant material.

Boron concentrations also varied in plant tissue. Potamogeton collected from the flood control and Felters Ponds had boron concentrations ranging from 800 to $2,130 \mu \mathrm{g} / \mathrm{g}$. Boron concentrations in filamentous-green algae from the desiltation pond ranged from 141 to $207 \mu \mathrm{g} / \mathrm{g}$. Young birds feeding on aquatic plants containing large boron concentrations may be affected adversely .

Selenium concentrations in invertebrate samples (excluding snails) ranged from $3.2 \mu \mathrm{g} / \mathrm{g}$ to $10.60 \mu \mathrm{g} / \mathrm{g}$, with a geometric mean of $7.3 \mu \mathrm{g} / \mathrm{g}$ (table 43). Data from the North Roadside Pond at Ouray NWR indicated that invertebrates had small selenium concentrations in September through mid-April and large concentrations from mid-April through July. Samples collected from Unit 1 were limited in number, but selenium concentrations appeared to follow the same pattern.

\section{Unit 2 - Pariette Wetlands}

Unit 2 consisted of Redhead and Gadwall Ponds (fig. 9). These sites are at the farthest downstream part of the wetlands, near the Green River. This unit corresponds to the lower part of the USBLM's River Unit.

\section{Nesting observations}

Nesting studies were conducted in 1987 and 1989 and consisted of searches for occupied nests and observation of bird use of nests. The primary emphasis was on American coot and pied-billed grebe in 1987 and was expanded to all waterbirds using the ponds in 1989.

A total of 11 American coot nests were monitored at the Gadwall Pond, and 2 were monitored at the Redhead Pond. Overall, 55 percent of American coot nests in Unit 2 that were monitored through completion of incubation were successful in hatching at least one egg. Of nests that were successful, none had unhatched eggs. Of the six random eggs collected, all contained live embryos.

Five pied-billed grebe nesting attempts were monitored in Unit 2. Four were successful (80 percent). Seven other nesting attempts that were monitored for ducks and geese had a nesting success of 57 percent. 


\section{Observations of waterbird use}

Counts conducted by the USBLM for the River Unit (approximately the same areas as Units 2 and 4 combined) indicate that the number of duck broods increased from 21 in 1987, to 44 in 1988 , to 45 in 1989, with average brood sizes of 6.3,5.4, and 6.3, respectively. Brood counts of American coots for these same years were 10,2 , and 15 , with average brood sizes of $2.5,4.5$, and 1.1, respectively (Tim Faircloth, U.S. Bureau of Land Management, oral commun., 1990). A small rookery for black-crowned night herons and snowy egrets was located at the Gadwall Pond.

\section{Residue in tissue}

Data from the ponds in Unit 2 were aggregated for analysis (table 44) and interpretation. When a range of values is cited, the values are for individual samples and data are from Peltz and Waddell (1991). A total of six eggs were collected randomly and one egg was collected non-randomly from American coot nests. Selenium concentrations in randomly collected American coot eggs ranged from 5.1 to $8.4 \mu \mathrm{g} / \mathrm{g}$, with a geometric mean concentration of $6.4 \mu \mathrm{g} / \mathrm{g}$ (dry weight). The non-randomly collected egg contained $5.8 \mu \mathrm{g} / \mathrm{g}$ selenium. Only the upper range exceeds the reference value of $8 \mu \mathrm{g} / \mathrm{g}$ found to affect reproduction adversely in populations of some species (Skorupa and Ohlendorf, 1991). The largest boron concentration in American coot eggs from this unit was $5 \mu \mathrm{g} / \mathrm{g}$.

Selenium concentrations in individual samples of bird eggs did not exceed $15 \mu \mathrm{g} / \mathrm{g}$. The geometric mean selenium concentration in all randomly collected bird eggs was $7.3 \mu \mathrm{g} / \mathrm{g}$, not measureably different from the geometric mean of $8.0 \mu \mathrm{g} / \mathrm{g}$ for non-randomly collected eggs.

The livers of two American coots sampled during the summer to assess brood-rearing conditions had a geometric mean selenium concentration of $6.6 \mu \mathrm{g} / \mathrm{g}$ (table 44). The concentrations were greater than in the birds from the control area at Leota Bottom at Ouray NWR but were small compared to concentrations believed to be associated with toxic effects. The liver from a juvenile piedbilled grebe taken in August contained a selenium concentration of $47 \mu \mathrm{g} / \mathrm{g}$.

Whole-body selenium concentrations in 24 samples of 4 species of fish ranged from a minimum of $1.8 \mu \mathrm{g} / \mathrm{g}$ in black bullhead to a maximum of $12.9 \mu \mathrm{g} / \mathrm{g}$ in common carp, both at Redhead Pond, with a geometric mean concentration of $6.6 \mu \mathrm{g} / \mathrm{g}$ for all samples combined (table 44). Two of the samples (8 percent), both common carp, exceeded the $12 \mu \mathrm{g} / \mathrm{g}$ level associated with reproductive failure (Lemly and Smith, 1987). The geometric mean selenium concentration in common carp was $8.7 \mu \mathrm{g} / \mathrm{g}$. Flannelmouth sucker, black bullhead, and green sunfish had smaller geometric mean selenium concentrations with $5.7,5.1$, and $6.0 \mu \mathrm{g} / \mathrm{g}$, respectively.

Plants analyzed from Unit 2 generally contained small selenium concentrations that ranged from $0.38 \mu \mathrm{g} / \mathrm{g}$ in cattail to $2.22 \mu \mathrm{g} / \mathrm{g}$ in a sample of horned pondweed, both from Gadwall Pond. Samples are summarized by taxonomic group and geometric mean selenium concentrations are listed in table 44. Boron concentrations in plants ranged from 9.8 to $651 \mu \mathrm{g} / \mathrm{g}$. The largest concentrations were in potamogeton and filamentous green algae. Potamogeton and filamentous green algae collected from Gadwall Pond had boron concentrations that exceeded $300 \mu \mathrm{g} / \mathrm{g}$.

Invertebrates were sampled from Gadwall Pond using light traps and invertebrate nets, and from food material removed from the stomachs of black bullheads. Selenium concentrations in these invertebrate samples ranged from $5.7 \mu \mathrm{g} / \mathrm{g}$ to $8.8 \mu \mathrm{g} / \mathrm{g}$, with a geometric mean of $7.0 \mu \mathrm{g} / \mathrm{g}$ (table 44).

\section{Unit 3 - Pariette Wetlands}

Unit 3 consisted of the following ponds or areas: Big Island, Small Island, Horseshoe, Roadside Cliff, Indian, and Mallard (fig. 9). These ponds are on the north side of Pariette Draw. This unit corresponds closely to the Uteland Unit as defined by USBLM. 
Table 44. Geometric mean selenium concentrations in biological samples collected from Gadwall and Redhead Ponds in Pariette Wetlands (Unit 2) and in fish samples collected nationwide by the National Contaminant Biomonitoring Program

[All eggs are random except those identified by NR, non-random; mm, millimeter; g, gram; $\mu \mathrm{g} / \mathrm{g}$, micrograms per gram (dry weight); - , not specified. NCBP, National Contaminant Biomonitoring Program, from

Schmitt and Brumbaugh, 1990 (1984 geometric mean concentration, 85th percentile converted to dry weight using 75 percent moisture). Weight of bird egg is mean weight of contents. Mean length, weight, and moisture content are arithmetic means]

\begin{tabular}{lcccccc}
\hline Species & $\begin{array}{c}\text { Sample } \\
\text { size }\end{array}$ & $\begin{array}{c}\text { Sample } \\
\text { type }\end{array}$ & $\begin{array}{c}\text { Mean } \\
\text { length } \\
(\mathrm{mm})\end{array}$ & $\begin{array}{c}\text { Mean } \\
\text { weight } \\
(\mathrm{g})\end{array}$ & $\begin{array}{c}\text { Mean } \\
\text { moisture } \\
\text { content } \\
\text { (percent) }\end{array}$ & $\begin{array}{c}\text { Geometric } \\
\text { mean selenium } \\
\text { concentration } \\
(\mu \mathrm{g} / \mathrm{g})\end{array}$ \\
\hline
\end{tabular}

American coot

Black-crowned night heron

Cinnamon teal

Gadwall

Mallard

Pied-billed grebe

Snowy egret

Yellow-headed blackbird

All random eggs

American coot (NR)

Pied-billed grebe (NR)

Ruddy duck (NR)

All non-random eggs

American coot liver

Pied-billed grebe liver

Black bullhead

Common carp

Flannelmouth sucker

Green sunfish

All fish

Fish, NCBP nationwide

Filamentous green algae

Najas marina

Potamogeton

Widgeongrass

Cattail

Horned pondweed

All non-emergent aquatics

Invertebrates, mixed

\section{Bird eggs}

6 Individual

2 Individual

2 Individual

3 Individual

1 Individual

2 Individual

3 Individual

1 Composite

20 Composite, Individual

1 Individual

2 Individual

1 Individual

4 Individual

\section{Bird tissue}

2 Individual

1 Individual

Fish

8 Composite 193

10 Composite, Individual

4 Composite

2 Composite, Individual

24 Composite, Individual

325

266

112

$\begin{array}{ll}\mathbf{5 0} & 25 \\ \mathbf{4 9} & 31 \\ \mathbf{4 6} & 28 \\ \mathbf{4 9} & \mathbf{4 2} \\ \mathbf{5 5} & 30 \\ \mathbf{4 2} & 18 \\ \mathbf{4 4} & 19 \\ 26 & 12 \\ - & -\end{array}$

75.3

80.6

69.2

69.5

68.2

78.1

78.3

84.0

75.1

69.0

77.9

72.3

74.3

72.2

74.7

6.6

47

6.4

10.1

11.0

5.4

6.0

7.5

6.7

12

7.3

5.8

8.5

9.6

8.0

-

81.3

5.1

78.2

74.0

73.4

78.1

8.7

5.7

6.0

6.6

$-\quad-\quad 75.0$

2.9

Plants

2 Composite

1.4

- $\quad-\quad 91.5$

93.9

1.2

- $\quad$ - 88.0

- $\quad$ - 85.0

1.4

1.3

88.2

.58

- $\quad-\quad 91.0$

2.2

1.4

\section{Invertebrates}

5 Composite

86.1

7.0 


\section{Nesting observations}

Nesting studies were conducted in 1987 and 1989 and consisted of searches for occupied nests and observation of bird use. The primary emphasis was on American coot and pied-billed grebe in 1987 and was expanded to all waterbirds using the ponds in 1989.

A total of 12 American coot nests were monitored. Overall, 58 percent of American coot nests monitored through completion of incubation in Unit 3 were successful in hatching at least one egg. Of the nests that were successful, none had unhatched eggs. Of the eight random eggs collected, it was uncertain whether the embryo of one egg was alive when collected.

Five pied-billed grebe nesting attempts were monitored in Unit 3. Two were successful (20 percent). Two random eggs were collected and both contained live embryos. One unhatched egg was found, and the contents consisted of a well-developed embryo that was dead but near full-term incubation with no obvious deformities.

Twelve other nesting attempts were monitored for ducks and geese, with a nesting success of 17 percent. At successful nests, no unhatched eggs were found. Of five random mallard eggs collected and examined, four eggs had embryos where viability was difficult to determine, which was believed to be due to egg handling. Three of these were believed to be live embryos, and one was a dead embryo. One randomly collected egg had a dead embryo, but no eggs hatched from this nest. Two nests of blacknecked stilts were monitored, and one was successful.

\section{Observations of waterbird use}

Counts conducted by the USBLM for the Uteland Unit (approximately the same areas as Unit 3) indicate that the number of duck broods varied from 11 in 1987 , to 4 in 1988, to 39 in 1989 , with average brood sizes of 4.3, 7, and 4.9, respectively. Numbers of American coot broods were 1 in 1987 and 18 in 1989, with average brood sizes of 5 and 1.2, respectively (Tim Faircloth, U.S. Bureau of Land Management, oral commun., 1989).

\section{Residue in tissue}

Data obtained on element residues from birds collected from the ponds in Unit 3 were aggregated for analysis and interpretation. Summaries of geometric mean selenium concentrations in individual and composite samples are presented by species in table 45 . When a range of values is cited, the values are for individual samples and data are from Peltz and Waddell (1991). A total of eight eggs were collected randomly from American coot nests. Selenium concentrations in these eggs ranged from 3.7 to $7.2 \mu \mathrm{g} / \mathrm{g}$, with a geometric mean concentration of $4.8 \mu \mathrm{g} / \mathrm{g}$. Boron concentrations of $5 \mu \mathrm{g} / \mathrm{g}$ or larger (range 6 to $8.5 \mu \mathrm{g} / \mathrm{g}$ ) were found in all four American coot eggs from Mallard Pond.

Selenium concentrations in the samples of bird eggs did not exceed $15 \mu \mathrm{g} / \mathrm{g}$, but concentrations in several eggs exceeded the $8 \mu \mathrm{g} / \mathrm{g}$ threshold associated with reproductive impairment (Skorupa and Ohlendorf, 1991, table 4). Selenium concentrations ranged from $1.39 \mu \mathrm{g} / \mathrm{g}$ in a randomly collected Canada goose egg to $15 \mu \mathrm{g} / \mathrm{g}$ in a randomly collected pied-billed grebe egg. Four eggs contained selenium concentrations of $10 \mu \mathrm{g} / \mathrm{g}$ or greater. A single redhead egg contained a selenium concentration of $13 \mu \mathrm{g} / \mathrm{g}$, a mallard egg contained $11 \mu \mathrm{g} / \mathrm{g}$, and a second pied-billed grebe egg contained $10 \mu \mathrm{g} / \mathrm{g}$. Six mallard eggs had a geometric mean selenium concentration of $5.1 \mu \mathrm{g} / \mathrm{g}$. Two pied-billed grebe eggs had a geometric mean selenium concentration of $12.2 \mu \mathrm{g} / \mathrm{g}$. Two of four mallard eggs collected from Big Island Pond had boron concentrations of 5 and $7 \mu \mathrm{g} / \mathrm{g}$.

The livers of four American coots sampled during the summer to assess brood-rearing conditions had a geometric mean selenium concentration of $8.2 \mu \mathrm{g} / \mathrm{g}$ (table 45) and ranged from 7.2 $\mu \mathrm{g} / \mathrm{g}$ to $9.8 \mu \mathrm{g} / \mathrm{g}$. These concentrations are larger than those found at the control area of Leota Bottom at Ouray NWR. 
Table 45. Geometric mean selenium concentrations in biological samples collected from Big Island, Small Island, Horseshoe, Mallard, Indian, and Roadside Cliff Ponds in Pariette Wetlands (Unit 3) and in fish samples collected nationwide by the National Contaminant Biomonitoring Program

[All eggs are random except those identified by NR, non-random; mm, millimeter; g, gram; $\mu \mathrm{g} / \mathrm{g}$, micrograms per gram (dry weight); - , not specified. NCBP, National Contaminant Biomonitoring Program, from Schmitt and Brumbaugh, 1990 (1984 geometric mean concentration, 85th percentile, converted to dry weight using 75 percent moisture). Weight of bird egg is mean weight of contents.

Mean length, weight, and moisture content are arithmetic means]

\begin{tabular}{|c|c|c|c|c|c|c|}
\hline Species & $\begin{array}{l}\text { Sample } \\
\text { size }\end{array}$ & $\begin{array}{c}\text { Sample } \\
\text { type }\end{array}$ & $\begin{array}{l}\text { Mean } \\
\text { length } \\
(\mathrm{mm})\end{array}$ & $\begin{array}{l}\text { Mean } \\
\text { weight } \\
\text { (g) }\end{array}$ & $\begin{array}{l}\text { Mean } \\
\text { moisture } \\
\text { content } \\
\text { (percent) }\end{array}$ & $\begin{array}{c}\text { Geometric } \\
\text { mean selenium } \\
\text { concentration } \\
(\mu \mathrm{g} / \mathrm{g})\end{array}$ \\
\hline \multicolumn{7}{|c|}{ Bird eggs } \\
\hline American coot & 8 & Individual & 49 & 22 & 74.3 & 4.8 \\
\hline Canada goose & 2 & Individual & 87 & 119 & 67.2 & 1.7 \\
\hline Canada goose (NR) & 1 & Individual & 87 & - & 68.1 & 2.1 \\
\hline Cinnamon teal & 2 & Individual & 44 & 23 & 68.0 & 8.8 \\
\hline Gadwall & 1 & Individual & 53 & 37 & 67.4 & 8.0 \\
\hline Mallard & 6 & Individual & 56 & 42 & 68.5 & 5.1 \\
\hline Pied-billed grebe & 2 & Individual & 43 & 20 & 76.9 & 12.2 \\
\hline Redhead & 1 & Individual & 60 & 48 & 67.3 & 13 \\
\hline Yellow-headed blackbird & 1 & Composite & 28 & 15 & 82.9 & 8.5 \\
\hline All random eggs & 23 & $\begin{array}{l}\text { Composite } \\
\text { and Individual }\end{array}$ & - & - & 71.6 & 5.4 \\
\hline \multicolumn{7}{|c|}{ Bird tissue } \\
\hline American coot liver & 4 & Individual & - & - & 71.1 & 8.2 \\
\hline \multicolumn{7}{|c|}{ Fish } \\
\hline Black bullhead & 8 & Composite & 209 & 168 & 82.1 & 5.5 \\
\hline Common carp & 7 & $\begin{array}{l}\text { Composite } \\
\text { and Individual }\end{array}$ & 407 & 768 & 74.9 & 5.6 \\
\hline Green sunfish & 2 & Composite & 160 & 124 & 74.2 & 7.2 \\
\hline All fish & 17 & $\begin{array}{l}\text { Composite } \\
\text { and Individual }\end{array}$ & 277 & 387 & 78.2 & 5.8 \\
\hline \multicolumn{7}{|c|}{ Plants } \\
\hline Chara & 2 & Composite & - & - & 79.4 & 1.2 \\
\hline Filamentous green algae & 1 & Composite & - & - & 90.6 & 2 \\
\hline Water milfoil & 1 & Composite & - & - & 80.9 & 1.04 \\
\hline Potamogeton & 6 & Composite & - & - & 86.7 & 1.3 \\
\hline Widgeongrass & 1 & Composite & - & - & 84.7 & 1.97 \\
\hline Cattail & 4 & Composite & - & - & 89.7 & .4 \\
\hline $\begin{array}{l}\text { All non-emergent rooted } \\
\text { aquatics, and Chara }\end{array}$ & 10 & Composite & - & - & 84.5 & 1.3 \\
\hline \multicolumn{7}{|c|}{ Invertebrates } \\
\hline Invertebrates, mixed & 4 & Composite & - & - & 76.4 & 6.5 \\
\hline
\end{tabular}


Whole-body selenium concentrations in 17 samples of 3 fish species collected from Big Island Pond ranged from a minimum of $3.8 \mu \mathrm{g} / \mathrm{g}$ (in carp) to a maximum of $8.71 \mu \mathrm{g} / \mathrm{g}$ (in carp). The geometric mean concentration for all fish samples was $5.8 \mu \mathrm{g} / \mathrm{g}$ (table 45). None of the samples exceeded the $12 \mu \mathrm{g} / \mathrm{g}$ concentration associated with reproductive failure (Lemly and Smith, 1987).

Plants analyzed from Unit 3 generally contained small selenium concentrations, ranging from less than $0.3 \mu \mathrm{g} / \mathrm{g}$ in cattail to $2.5 \mu \mathrm{g} / \mathrm{g}$ in potamogeton at Big Island Pond. Boron concentration in plants were large; potamogeton had a geometric mean boron concentration of $434 \mu \mathrm{g} / \mathrm{g}$ and ranged from 219 to $723 \mu \mathrm{g} / \mathrm{g}$. A single sample of filamentous green algae from Big Island Pond contained a boron concentration of $325 \mu \mathrm{g} / \mathrm{g}$. The health of young birds feeding on aquatic plants containing this much boron could be affected adversely.

Invertebrates were sampled from Big Island Pond using light traps and invertebrate nets. Selenium concentrations in these invertebrate samples ranged from $4.70 \mu \mathrm{g} / \mathrm{g}$ to $9.3 \mu \mathrm{g} / \mathrm{g}$, with a geometric mean of $6.5 \mu \mathrm{g} / \mathrm{g}$ (table 45).

\section{Unit 4 - Pariette Wetlands}

Unit 4 consisted of Pintail and Shoveler Ponds (fig. 9). These ponds are on the south side of Pariette Draw between Units 1 and 2. This unit is a subdivision of the USBLM's River Unit.

\section{Nesting observations}

Nesting studies done primarily in 1989 consisted of searches for occupied nests and observation of bird use of nests. Twelve nesting attempts monitored for shorebirds, ducks, and geese had a nesting success of 42 percent. Only the Canada goose nest monitored was successful in hatching all eggs.

Unhatched eggs were found at four of the five successful nests (mallard, northern shoveler, killdeer, and cinnamon teal). Cumulatively, these eggs included two infertile eggs, two badly decomposed eggs with little or no development detected, and three eggs with well-developed embryos. Two of these developed embryos were from a nest possibly affected by rising water; however, five other eggs in the nest hatched and another egg had contents that were rotten and showed little observable development. The three dead embryos with different stages of development may have died from causes other than rising water.

Examination of random eggs disclosed two nests that had eggs with problems, but either the eggs were destroyed before incubation was complete or monitoring was prematurely terminated. One egg was apparently infertile, and the other contained a dead embryo. At another nest, examination of eggs from an unsuccessful nest that was flooded indicated one of the embryos had died much earlier than the other six. The randomly collected egg from this nest had a live embryo. Nesting success for the combined data for individual species at the two ponds was one of one Canada goose, none of two gadwall, one of one mallard, one of two shoveler, one of five cinnamon teal, and one of one killdeer.

\section{Observations of waterbird use}

Brood counts for this unit are reported under the discussion for Unit 2.

\section{Residue in tissue}

Tissue residue data from the ponds in Unit 4 were aggregated for analysis (table 46) and interpretation. When a range of values is cited, the values are for individual samples and data are from Peltz and Waddell (1991). Selenium concentrations in bird egg samples did not exceed $15 \mu \mathrm{g} / \mathrm{g}$. Selenium concentrations in all eggs had a geometric mean of $5.8 \mu \mathrm{g} / \mathrm{g}$ and ranged from $2.52 \mu \mathrm{g} / \mathrm{g}$ in a randomly collected Canada goose egg to $9.5 \mu \mathrm{g} / \mathrm{g}$ in a randomly collected cinnamon teal egg. Cinnamon 
teal was the only species for which more than two eggs were collected; and the geometric mean selenium concentration of the eggs was $7.5 \mu \mathrm{g} / \mathrm{g}$.

Boron concentrations were large in some egg samples relative to concentrations in samples from the Leota Bottom area at Ouray NWR. Boron concentrations in eggs were as large as $7.66 \mu \mathrm{g} / \mathrm{g}$ in a Canada goose egg. Seven of the 13 eggs, however, had boron concentrations that were less than the reporting limit. One sample of an individual green sunfish was obtained from Shoveler Pond and contained a selenium concentration of $4.2 \mu \mathrm{g} / \mathrm{g}$ and a boron concentration of $8.27 \mu \mathrm{g} / \mathrm{g}$.

Plants analyzed from Unit 4 generally contained small selenium concentrations that ranged from less than $0.3 \mu \mathrm{g} / \mathrm{g}$ in widgeongrass at Pintail Pond to $1.6 \mu \mathrm{g} / \mathrm{g}$ in potamogeton at Shoveler Pond. Samples are summarized by taxonomic group in table 46. Boron in nine plant samples ranged from a minimum of $23 \mu \mathrm{g} / \mathrm{g}$ in cattail to a maximum of $1,140 \mu \mathrm{g} / \mathrm{g}$ in potamogeton. Both samples were collected at Shoveler Pond in July and August of 1987.

Selenium concentrations in two invertebrate samples were $6.4 \mu \mathrm{g} / \mathrm{g}$ and $7.97 \mu \mathrm{g} / \mathrm{g}$; the geometric mean was $7.1 \mu \mathrm{g} / \mathrm{g}$. Boron was detected in one sample at a concentration of $25.6 \mu \mathrm{g} / \mathrm{g}$.

Table 46. Geometric mean selenium concentrations in biological samples collected from Pintail and Shoveler Ponds in Pariette Wetlands (Unit 4)

[All eggs are random; mm, millimeter; g, gram; $\mu \mathrm{g} / \mathrm{g}$, micrograms per gram (dry weight); -, not specified; *, single real data point. Weight of bird egg is mean weight of contents. Mean length, weight, and moisture content are arithmetic means]

\begin{tabular}{lcccccc}
\hline Species & Sample & Sample & Mean \\
size & type & $\begin{array}{c}\text { Mean } \\
\text { length } \\
(\mathrm{mm})\end{array}$ & $\begin{array}{c}\text { Meight } \\
(\mathrm{g})\end{array}$ & $\begin{array}{c}\text { Mean } \\
\text { moisture } \\
\text { content } \\
(\text { percent) }\end{array}$ & $\begin{array}{c}\text { Geometric } \\
\text { mean selenium } \\
\text { concentration } \\
(\mu \mathrm{g} / \mathrm{g})\end{array}$ \\
\hline
\end{tabular}

American avocet
Canada goose
Cinnamon teal
Gadwall
Killdeer
Mallard
Northern shoveler
All eggs

Chara

Filamentous green algae

Water milfoil

Potamogeton

Widgeongrass

Cattail

All non-emergent rooted aquatics, and Chara

Invertebrates, mixed

\section{Bird eggs}

$\begin{array}{rrrrll}1 & \text { Individual } & 45 & - & 70.0 & 6.1 \\ 1 & \text { Individual } & 88 & 120 & 66.9 & 2.52 \\ 5 & \text { Individual } & 47 & 23 & 67.2 & 7.5 \\ 2 & \text { Individual } & 53 & 39 & 67.5 & 4.3 \\ 1 & \text { Individual } & 39 & 10 & 68.4 & 3.9 \\ 1 & \text { Individual } & - & 26 & 66.6 & 8.9 \\ 2 & \text { Individual } & 51 & 35 & 68.1 & 6.2 \\ 13 & \text { Individual } & - & - & 67.6 & 5.8\end{array}$

\section{Plants}

\begin{tabular}{llllll}
1 & Composite & - & - & 90.2 & .8 \\
1 & Composite & - & - & 85.1 & 1.4 \\
1 & Composite & - & - & 85.6 & .855 \\
3 & Composite & - & - & 85.9 & 1.0 \\
2 & Composite & - & - & 89.0 & $* .590$ \\
1 & Composite & - & - & 84.7 & .34 \\
7 & Composite & - & - & 87.4 & .9 \\
& \multicolumn{2}{c}{ Invertebrates } & & & \\
& Composite & - & - & 83.3 & 7.1 \\
\hline
\end{tabular}




\section{STREAMFLOW, WATER QUALITY, AND BIOTA OF THE GREEN RIVER}

All surface water and most shallow ground water in the middle Green River basin eventually discharges to the Green River. The reconnaissance study done in 1986-87 (Stephens and others, 1988a) and the detailed study done in 1988-90 followed record large flows from 1983 to 1986 (fig. 57). Hydrologic conditions during 1986-89 ranged from flooding to near record drought.

\section{Evaporite Minerals and Water Quality}

The abundance of evaporite minerals in the middle Green River basin results in large quantities of dissolved solids and certain trace elements, notably selenium and boron, entering the Green River. A summary of dissolved-solids concentrations in tributaries and in the Green River during water years 1988 and 1989 is shown in figure 58. Water leaving Flaming Gorge Reservoir (near Greendale) contains only small concentrations of dissolved solids. At Jensen, the total discharge of the river typically has more than doubled due to inflow from the Yampa River, but the dissolved-solids concentration has not changed markedly. Inflows from Stewart Lake, Ashley Creek, and the Duchesne and Price Rivers contain larger concentrations of dissolved solids. The tributaries entering the Green River between Greendale and Green River, Utah, increased the mean dissolved-solids concentration in the Green River from 456 to $526 \mathrm{mg} / \mathrm{L}$ during 1988 and 1989.

Similar increases in concentration also occurred for selenium (fig. 59). Mean concentrations increased from near the reporting level of $1 \mu \mathrm{g} / \mathrm{L}$ at Greendale to a mean of $2 \mu \mathrm{g} / \mathrm{L}$ at Green River, Utah. Large selenium concentrations were present in water discharged from Stewart Lake (mean 6.7 $\mu \mathrm{g} / \mathrm{L}$ ) and Ashley Creek (mean $88 \mu \mathrm{g} / \mathrm{L}$ ).

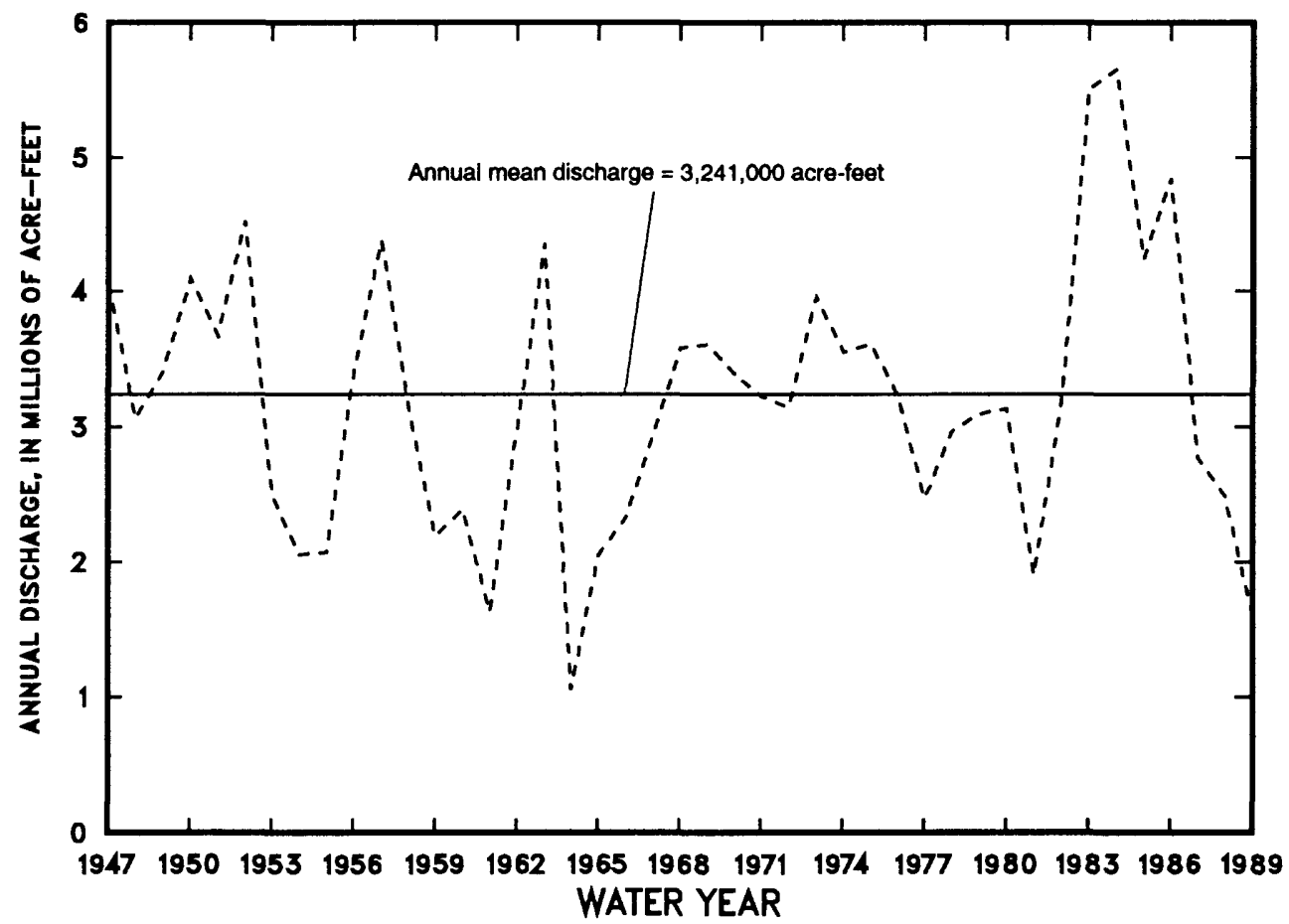

Figure 57. Annual discharge of the Green River near Jensen, Utah, for water years 1947-89. 


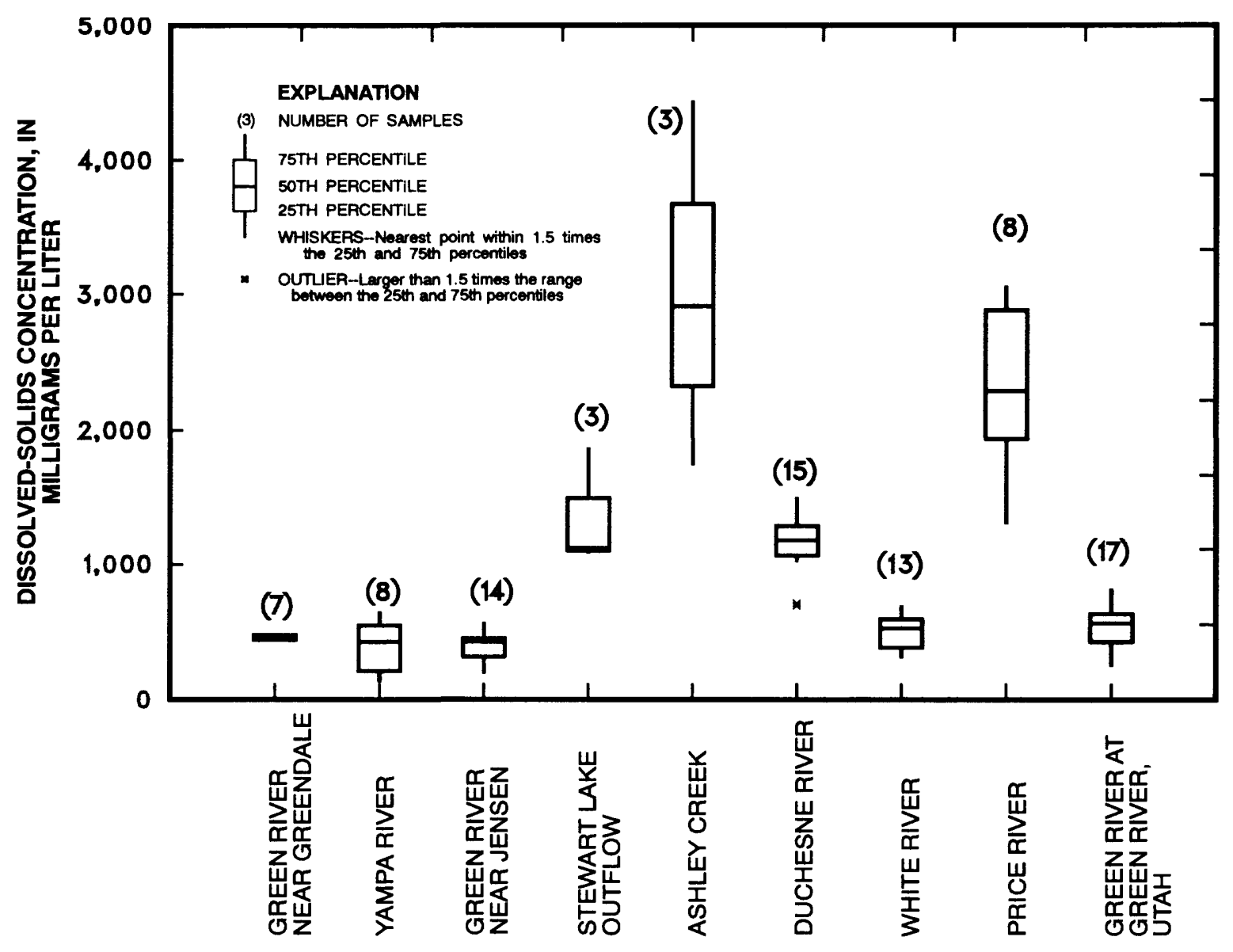

Figure 58. Dissolved-solids concentrations in the Green River and in tributaries discharging to the Green River, water years 1988 and 1989.

Data available for 1988-89 are few but show several tributary inflows contributed large boron concentrations to the Green River (fig. 60). Median boron concentrations contributed by the Duchesne River and Pariette Draw (1 sample) exceeded the State standard of $750 \mu \mathrm{g} / \mathrm{L}$ established to protect agriculture. Data were not available for the 1988-89 inflow from Ashley Creek, but the mean boron concentration in three samples from $1986-87$ was $480 \mu \mathrm{g} / \mathrm{L}$.

While of interest in identifying sources of contamination, concentration data alone do not properly indicate the effects of contamination on the river and downstream uses. Because of the large volume of water transported by the Green River, a large concentration of a contaminant entering the river in a small discharge will be diluted, possibly to the point of having no adverse effect. Conversely, a small concentration of a contaminant in a large discharge can result in a large total load of that contaminant to the river. Mean discharges and mean concentrations of dissolved solids and dissolved selenium in the Green River and its major tributaries during water years 1988-89 are shown in table 47. The mean daily load for each of the two constituents was calculated as the simple product of mean discharge and mean concentration. The distribution of the loads is of particular interest, especially for Ashley Creek, which contributed over 16 percent of the selenium load $(3 \mathrm{~kg} /$ day) and 2 percent of the load of dissolved solids, but provided only 0.4 percent of the total flow at Green River, Utah. The Price River, which also drains soils of Mancos Shale, contributed nearly half of the total selenium load $(9.4 \mathrm{~kg} /$ day) present at Green River, Utah, in about 2 percent of the total flow (fig. 61). 


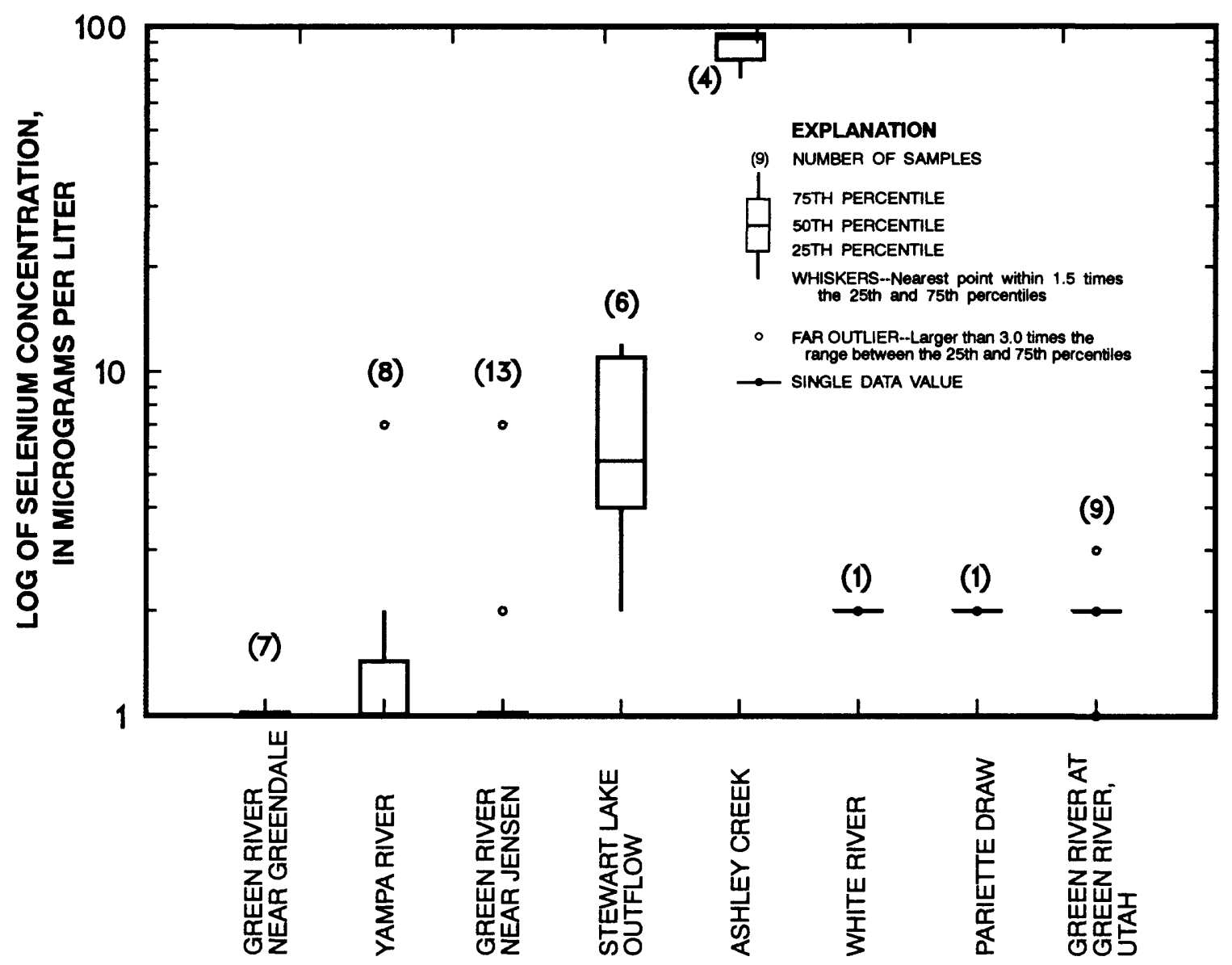

Figure 59. Selenium concentrations in the Green River and in tributaries discharging to the Green River, water years 1988 and 1989.

\section{Trace Elements in Biota in the Green River}

Sampling of organisms in the Green River was limited to individual samples and three composite samples of fish at five Green River sites during 1987, and all data appear in Peltz and Waddell (1991, p. 213). Selenium concentrations in fish ranged from 1.9 to $3.7 \mu \mathrm{g} / \mathrm{g}$ near Brown's Park; 2.7 to $4.2 \mu \mathrm{g} / \mathrm{g}$ near Echo Park in Dinosaur National Monument; 3.2 to $22.2 \mu \mathrm{g} / \mathrm{g}$ near the confluence with Ashley Creek; 3 to $4.4 \mu \mathrm{g} / \mathrm{g}$ near the town of Ouray; and 2.2 to $5.4 \mu \mathrm{g} / \mathrm{g}$ downstream from the confluence with the Price River. A summary of selenium concentrations in fish samples is shown in figure 62. Additional samples were collected in previous years near the confluence with Ashley Creek and near the town of Ouray under the National Contaminant Biomonitoring Program of the USFWS.

Near the confluence with Ashley Creek, a sample of common carp contained a selenium concentration of $10 \mu \mathrm{g} / \mathrm{g}$ in 1986, and a sample of flannelmouth sucker contained $3.1 \mu \mathrm{g} / \mathrm{g}$. In 1987 , a composite sample of carp from this site contained a geometric mean selenium concentration of 19.4 $\mu \mathrm{g} / \mathrm{g}$, considerably larger than a reference value of $12 \mu \mathrm{g} / \mathrm{g}$ in whole-body fish associated with reproductive impairment (Lemly and Smith, 1987). Fish tissues from the endangered Colorado squawfish were obtained from an archived fish reportedly taken in 1982 near the confluence of Ashley Creek. The fish had selenium concentrations of $2.7,6.5$, and $9.2 \mu \mathrm{g} / \mathrm{g}$ in muscle, gonads, and liver, respectively. A sample of eggs from a razorback sucker, an endangered species collected near Jensen in 1988 , had a selenium concentration of $4.9 \mu \mathrm{g} / \mathrm{g}$. 


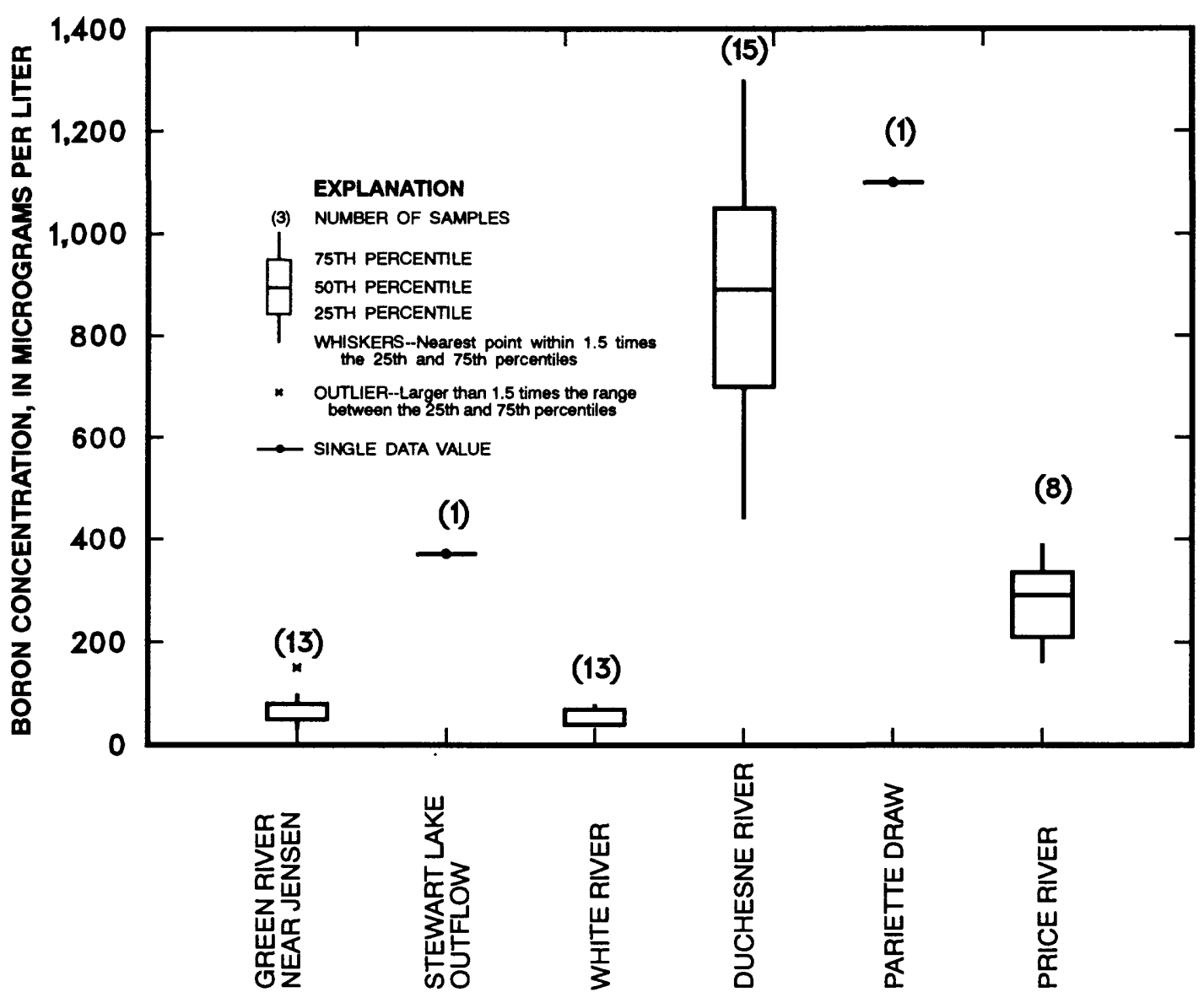

Figure 60. Boron concentrations in the Green River and in tributaries discharging to the Green River, water years 1988 and 1989.

Table 47. Mean daily discharge, mean dissolved-solids and selenium concentrations, and mean daily dissolved-solids and selenium load in the Green River and its major tributaries, water years 1988 and 1989

$\left[\mathrm{ft}^{3} / \mathrm{s}\right.$, cubic feet per second; $\mathrm{mg} / \mathrm{L}$, milligrams per liter; $\mu \mathrm{g} / \mathrm{L}$, micrograms per liter; $\mathrm{t} / \mathrm{day}$, ton per day; $\mathrm{kg} / \mathrm{day}$, kilograms per day; <, less than]

\begin{tabular}{|c|c|c|c|c|c|}
\hline \multirow[b]{2}{*}{ Site } & \multirow[b]{2}{*}{$\begin{array}{l}\text { Mean daily } \\
\text { discharge } \\
\left(\mathrm{ft}^{3} / \mathrm{s}\right)\end{array}$} & \multicolumn{2}{|c|}{ Mean concentration } & \multicolumn{2}{|c|}{ Mean load } \\
\hline & & $\begin{array}{l}\text { Solids, } \\
\text { dissolved } \\
(\mathrm{mg} / \mathrm{L})\end{array}$ & $\begin{array}{c}\text { Selenium, } \\
\text { dissolved } \\
(\mu \mathrm{g} / \mathrm{L})\end{array}$ & $\begin{array}{l}\text { Solids, } \\
\text { dissolved } \\
\text { (t/day) }\end{array}$ & $\begin{array}{c}\text { Selenium, } \\
\text { dissolved } \\
\text { (kg/day) }\end{array}$ \\
\hline Green River near Greendale, Utah & $1,358.0$ & 456 & $<1.0$ & 1,515 & 3.3 \\
\hline Yampa River near Maybell, Colorado & $1,074.0$ & 393 & 1.9 & 1,032 & 5 \\
\hline Green River near Jensen, Utah & $2,815.0$ & 391 & 1.5 & 2,693 & 10.3 \\
\hline Stewart Lake outflow & 5.7 & 1,357 & 6.7 & 19 & .1 \\
\hline Ashley Creek near Jensen, Utah & 14.0 & 3,030 & 88.0 & 104 & 3 \\
\hline Duchesne River near Randlett, Utah & 189.0 & 1,156 & 1.0 & 535 & .5 \\
\hline White River near Watson, Utah & 642.0 & 504 & 2.0 & 792 & 3.1 \\
\hline Price River at Woodside, Utah & 59.0 & 2,321 & 6.5 & 335 & 9.4 \\
\hline Green River at Green River, Utah & $3,711.0$ & 526 & 2.0 & 4,776 & 18.2 \\
\hline
\end{tabular}




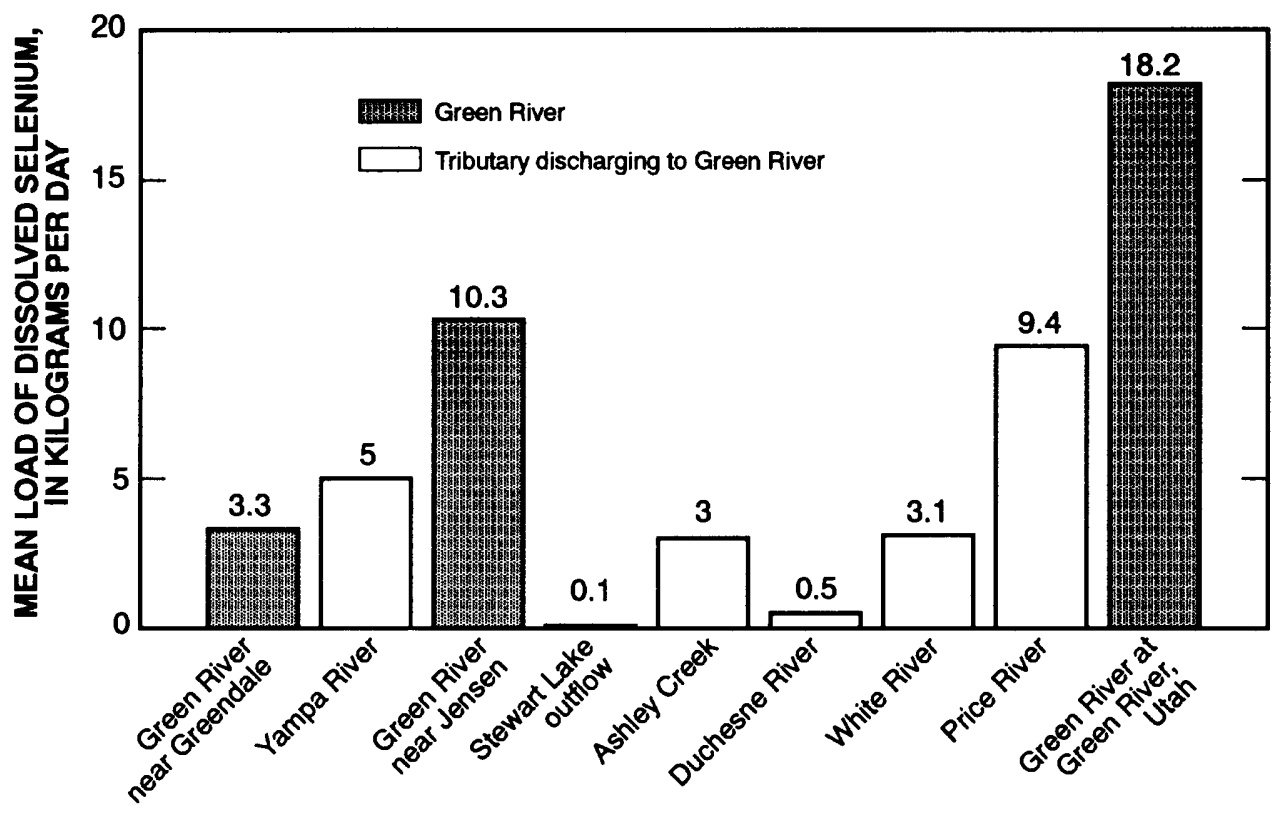

Figure 61. Mean daily load of dissolved selenium in the Green River and in tributaries discharging to the Green River, water years 1988 and 1989.

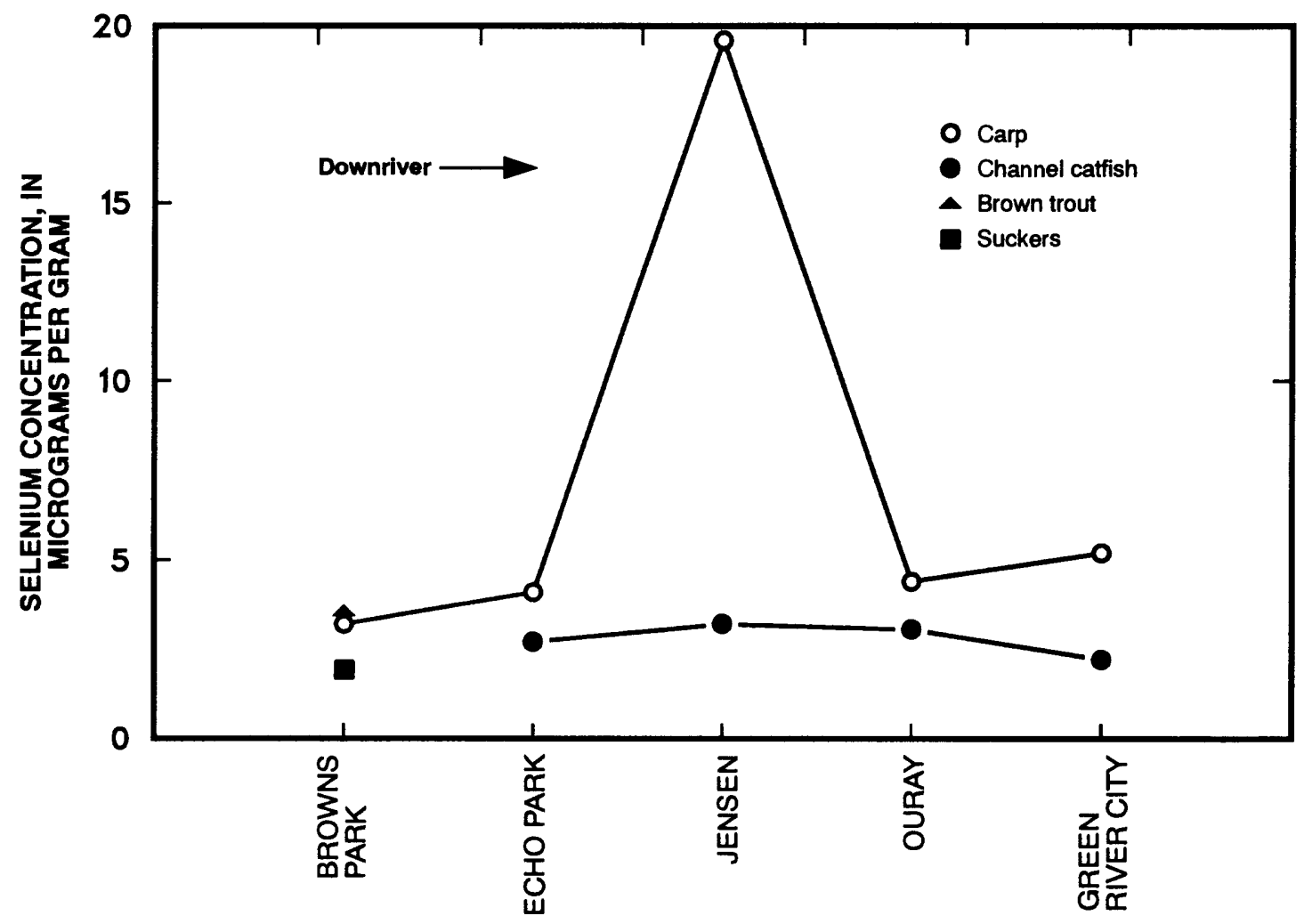

Figure 62. Selenium concentrations in fish collected at selected locations in the Green River in 1987. 
Fish samples have been collected near the town of Ouray, Utah, since 1978 under the National Contaminant Biomonitoring Program (Lowe and others, 1985; Schmitt and Brumbaugh, 1990; and Schmitt, U.S. Fish and Wildlife Service, written commun., 1991). The analytical results for samples collected in 1988 are not available; however, the results from samples collected in 1978, 1980, 1984, and draft results for 1986 are available. Two composite samples of common carp and one composite sample of smallmouth bass were collected during each sampling period except 1986, when one composite sample of channel catfish was analyzed due to the lack of availability of smallmouth bass. Selenium concentrations ranged from 2.62 to $7.57 \mu \mathrm{g} / \mathrm{g}$ for common carp and from 2.86 to $3.61 \mu \mathrm{g} / \mathrm{g}$ for smallmouth bass, and were $2.79 \mu \mathrm{g} / \mathrm{g}$ for channel catfish. Selenium concentrations in eight of nine samples exceeded the 85th percentile for data collected throughout the United States for years 1978 through 1984.

Unique samples were collected at a number of sites. One humpback chub salvaged from the Green River in 1986 (specific site undetermined) had 4.3,6, and $7 \mu \mathrm{g} / \mathrm{g}$ of selenium in its muscle, liver, and gonads, respectively. One Canada goose egg taken from a nest on an island in the Green River near Stewart Lake WMA had a selenium concentration of $3.38 \mu \mathrm{g} / \mathrm{g}$. Two livers salvaged from nestling great blue herons from the rookery near Stewart Lake had a mean selenium concentration of $10 \mu \mathrm{g} / \mathrm{g}$. Selenium concentrations in northern pike ranged from $6.1 \mathrm{\mu g} / \mathrm{g}$ in muscle of a fish collected near Stewart Lake WMA to $0.8 \mu \mathrm{g} / \mathrm{g}$ in a whole-body sample (without stomach) collected near Ouray, Utah.

Mercury concentrations were generally less than $1 \mu \mathrm{g} / \mathrm{g}$ in animal tissues, although moderate concentrations were found in Colorado squawfish muscle, $2.56 \mu \mathrm{g} / \mathrm{g}$; northern pike muscle and whole body, $1.1 \mu \mathrm{g} / \mathrm{g}$ and $1.44 \mu \mathrm{g} / \mathrm{g}$, respectively; and a juvenile great blue heron liver, $1.8 \mu \mathrm{g} / \mathrm{g}$. Neither of the single samples of Colorado squawfish or northern pike muscle had concentrations exceeding the FDA action level of $1 \mathrm{ppm}(1 \mu \mathrm{g} / \mathrm{g})$ wet weight recommended for human consumption. Geometric mean mercury concentrations in whole-body fish for all species combined nationwide in the National Contaminant Biomonitoring Program ranged from 0.10-0.12 $\mu \mathrm{g} / \mathrm{g}$ wet weight (estimated at 0.4-0.48 $\mu \mathrm{g} / \mathrm{g}$ dry weight using 75 percent moisture) between 1976 and 1984 (Schmitt and Brumbaugh, 1990). The 85 th percentile in 1984 was $0.17 \mu \mathrm{g} / \mathrm{g}$ wet weight (estimated $0.68 \mu \mathrm{g} / \mathrm{g}$ dry weight). Feeding studies on mallards (Heinz, 1979) indicated that reproductive impairment may occur with mercury concentrations as small as $0.5 \mu \mathrm{g} / \mathrm{g}$ dry weight; however, the concentration at which fish-eating birds may be affected is not known. A concentration of $0.5 \mu \mathrm{g} / \mathrm{g}$ was exceeded in 9 of 22 samples of individual fish (either whole-body or muscle samples) from the Green River. An exception was that most samples (8 of 11) near the confluences of Ashley Creek and the Price River and near Green River, Utah, contained concentrations that were less than $0.5 \mu \mathrm{g} / \mathrm{g}$. Four samples of 22 exceeded the 85 th percentile of the National Contaminant Biomonitoring Program (Schmitt and Brumbaugh, 1990).

\section{BIOACCUMULATION OF SELENIUM}

Selenium is an essential element for some plants and most animals. In animals it is incorporated into glutathione peroxidase, an enzyme that protects cells from damage due to molecular oxygen, and into several cytochromes, myoglobin, and hemoglobin. When selenium is taken up by organisms in excess of the trace amount required and at a rate greater than it can be excreted, it may bioaccumulate in cells and tissues. If an organism bioaccumulating selenium is then eaten by another organism, considerable magnification of the original selenium concentration may occur through the food chain.

Bioaccumulation of selenium at four sites in the middle Green River basin is shown in figures 63 and 64 . The figures present geometric mean concentrations of selenium in water, bottom sediment, and several groupings of organisms. Selenium concentrations in water are given in $\mu \mathrm{g} / \mathrm{L}$ and in bottom sediment and biota in $\mu \mathrm{g} / \mathrm{kg}$. Both units of measurement are equivalent to parts per billion. Dashed lines were used to aid the reader by linking groups common to each site and were not meant to imply a direct trophic link between any of the groups. At Stewart Lake, the geometric mean concentration of selenium in samples of drain and lake water was $28 \mu \mathrm{g} / \mathrm{L}$ and in whole-body fish was $24,000 \mu \mathrm{g} / \mathrm{kg}$, indicating a bioaccumulation factor of 850 between water and fish (fig. 63). Bioaccumulation factors between water and sediment and water and other organism groups ranged from about 300 to 700 . 
Bioaccumulation factors between successive trophic levels such as sediment and plant groups (cattails and non-emergent plants) and between plant groups and animals were much smaller (usually 2 to 5 ). These factors are similar to selenium bioaccumulation factors of 2 to 6 between successive trophic levels of a food chain reported by Lemly and Smith (1987, p. 9). Bioaccumulation ranged from about 400 to 2,200 in samples from Leota Bottom, an uncontaminated area at Ouray NWR, but selenium concentrations in the water, bottom sediment, and all forms of biota were an order of magnitude smaller than at Stewart Lake.

The potential for bioaccumulation was much greater at the Roadside Ponds at Ouray NWR where the geometric mean concentration of selenium in the water was nearly $32 \mu \mathrm{g} / \mathrm{L}$, bottom sediment accumulated $13,110 \mu \mathrm{g} / \mathrm{kg}$, and whole-body fish $48,300 \mu \mathrm{g} / \mathrm{kg}$, with bioaccumulation factors ranging from 400 to 1,500 times the selenium concentration in the water (fig. 64). Selenium concentrations in Sheppard Bottom were intermediate between the uncontaminated sites in Leota Bottom and the contaminated sites at the Roadside Ponds, and bioaccumulation factors ranged from 400 to 2,200. Selenium bioaccumulation factors between water and biota in the middle Green River basin were similar at all sites and were of the same magnitude as the factor of 1,430 reported for water to waterfowl at Kesterson NWR by DuBowy (1989).

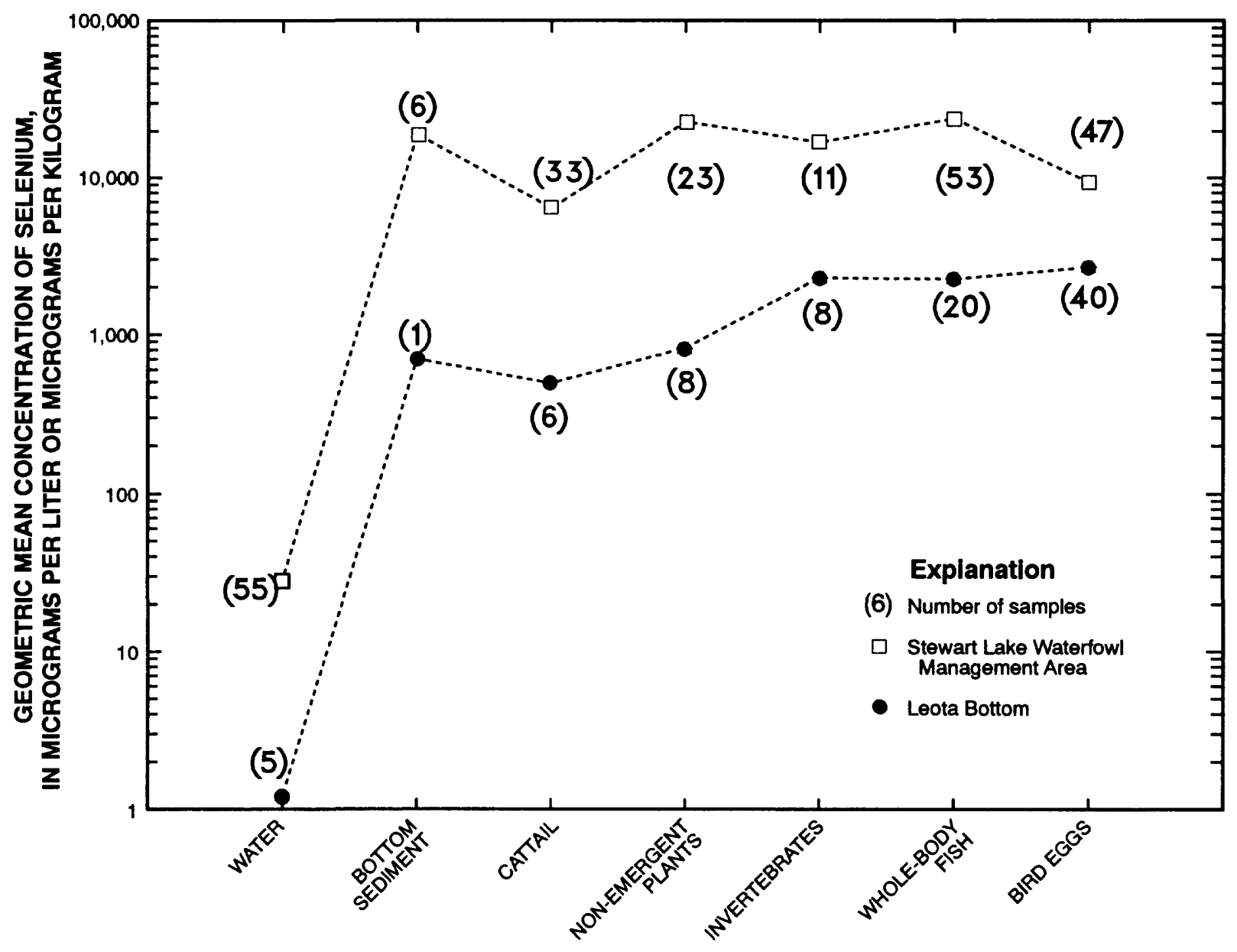

Figure 63. Geometric mean selenium concentrations in water, bottom sediment, and biota from Stewart Lake Waterfowl Management Area and Leota Bottom, an uncontaminated area of Ouray National Wildlife Refuge. 


\section{SELENIUM IN THE MIDDLE GREEN RIVER BASIN AND IMPLICATIONS FOR HUMAN HEALTH}

Selenium is necessary for human nutrition in quantities ranging from 50 to $200 \mu \mathrm{g} /$ day depending on age, weight, and sex (National Academy of Sciences, 1983). If the diet does not supply sufficient selenium, such diseases as Keshan (juvenile cardiomyopathy) and Kaschin-Beck (chondrodystrophy in children) may occur (Combs and Combs, 1986, p. 347). If the diet or industrial exposure provides too much selenium, acute selenosis, characterized by dizziness, nausea, and fatigue may occur, but rarely will death occur.

Chronic selenosis is associated with long-term exposure to small concentrations of selenium. Symptoms include skin lesions, hair loss, depression, and fatigue. The most notable example of chronic exposure to selenium was observed in a family living near Durango, Colorado, 225 mi southeast of the Uinta Basin, in which all members, including a dog, suffered hair loss, nausea, and fatigue. The cause was traced to water from a domestic well that contained a selenium concentration of $9,000 \mu \mathrm{g} / \mathrm{L}$. The well was in deposits of Mancos Shale (Beath, 1962). Aside from isolated incidents such as this, chronic selenosis in the United States is virtually unheard of because of the varied nature of the American diet (Fan and Kizer, 1990).

Virtually all households in areas of the Uinta Basin where selenium contamination was documented (Stephens and others, 1988a) receive culinary water from public water supplies that are not contaminated with selenium. Water from a private well near Vernal currently being used as a

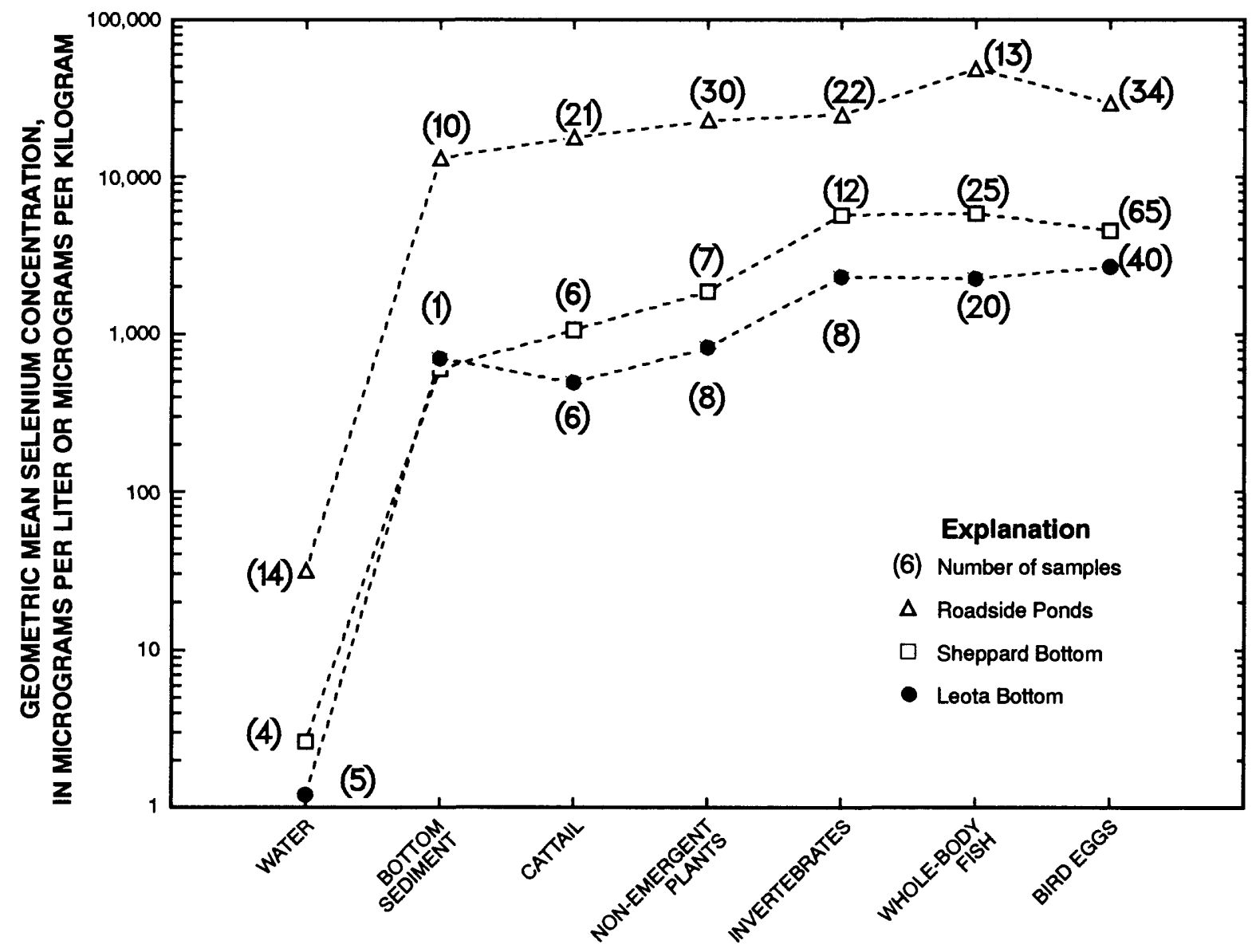

Figure 64. Geometric mean selenium concentrations in water, bottom sediment, and biota from the Roadside Ponds, Sheppard Bottom, and Leota Bottom at Ouray National Wildlife Refuge. 
culinary source was analyzed, but the selenium concentration was not in excess of the State drinking water standard of $10 \mu \mathrm{g} / \mathrm{L}$. A selenium concentration of $90 \mu \mathrm{g} / \mathrm{L}$ was detected in water from a private culinary well near Ouray.

Selenium can be bioaccumulated through the food chain, resulting in concentrations in foods, which, when eaten, can increase selenium levels enough to exceed the upper limit of $200 \mu \mathrm{g} / \mathrm{day}$ considered to be "safe and adequate" by the National Academy of Sciences (1980). The safe upper limit for humans, however, is regarded by some experts to be as large as $775 \mu \mathrm{g} /$ day (Combs and Combs, 1986, p. 511). Selenium concentrations in several samples of vegetables and fish and game tissues from the middle Green River basin are shown in table 48. Concentrations are given as raw, wet weight, because that is the form most likely encountered by consumers. In general, very little reduction of selenium occurs when foods are cooked (Higgs and others, 1972). The asparagus from Stewart Lake was collected from a ditch that receives only irrigation tailwater and does not represent water from the main body of the lake. The cabbage and radishes were collected from a household garden at Ouray NWR irrigated with water containing less than $1 \mu \mathrm{g} / \mathrm{L}$ of selenium.

The large selenium concentrations in fillets of carp and catfish and in breast tissue from coots from Stewart Lake prompted the Utah Department of Health to issue an advisory on September 26, 1988, for fish and fowl from Stewart Lake. Consumption of no more than $10 \mathrm{oz}$ per week for adult males was recommended.

Large selenium concentrations also were found in all of the limited number of organisms sampled from Ashley Creek and the adjacent Winter Storage Pond. Consumption of less than $1 \mathrm{oz}$ of fish or crayfish taken from Ashley Creek downstream of 500 North Street in Vernal, would provide the maximum daily adult intake of selenium recommended by the National Academy of Sciences. The contamination in Ashley Creek extends to the confluence with the Green River and was likely responsible for the large selenium concentration in a Northern pike and other fish collected at the confluence (table 48). The Utah State Health Department issued a health advisory on August 22, 1991, recommending limited consumption of fish and waterfowl from Ashley Creek downstream of 500 North Street and from the Winter Storage Pond.

Samples of fish from Pelican Lake, a popular bluegill fishery $4 \mathrm{mi}$ north of Ouray NWR, contained a very small quantity of selenium. Concentrations in organisms from the Leota Bottom area at Ouray NWR were generally small. This area of the refuge receives water from the Green River that has consistently contained little or no selenium. The water source for the Roadside Ponds and a partial source for Sheppard Bottom is seepage that contains large selenium concentrations that bioaccumulate in organisms. The large concentrations found in wildlife from the area of the Roadside Ponds and Sheppard Bottom at Ouray NWR resulted in closure of the affected areas to public access for a short period in 1988, although hunting and fishing have always been prohibited in these areas.

\section{SUMMARY AND CONCLUSIONS}

This report details the results of a study (1988-90) to define the extent and severity of irrigation-induced water-quality problems and provides information needed for development of alternatives to resolve identified problems. Emphasis was placed on Stewart Lake WMA near Jensen, Utah, and at Ouray NWR, $30 \mathrm{mi}$ south of Stewart Lake. Additional reconnaissance was completed on Ashley Creek near Vernal, Utah, and at Pariette Wetlands, 20 mi south of Ouray NWR.

The only source of surface-water inflow to Stewart Lake was drainwater from irrigated land in the Jensen area. Movement of shallow ground water in the Jensen area was generally to the south and east toward Stewart Lake and the Green River. Dissolved-solids concentrations in the drainwater typically increased ten fold from concentrations in the irrigation water due to dissolution of soil salts.

Because of tightly packed soils, water applied to the land surface could take from 3.5 to 5.6 years to enter a drain lateral. The water type found in shallow wells in the Jensen area was similar to the type discharged by the drains to Stewart Lake. 
Table 48. Selenium concentrations in human food items from selected areas in the middle Green River basin and the quantity of each that could be consumed without exceeding a safe and adequate daily quantity recommended for an adult male (National Academy of Sciences, 1980)

[ $\mu g / g$, micrograms per gram; NWR, National Wildlife Refuge; <, less than]

\begin{tabular}{|c|c|c|c|c|}
\hline Food item & $\begin{array}{l}\text { Number of } \\
\text { Samples }\end{array}$ & Sample location & $\begin{array}{c}\text { Selenium } \\
\text { concentration } \\
(\mu \mathrm{g} / \mathrm{g}, \text { wet weight })\end{array}$ & $\begin{array}{l}\text { Quantity consumed } \\
\text { to equal } 200 \mu \mathrm{\mu g} / \text { day } \\
\text { (ounces, wet weight) }\end{array}$ \\
\hline Asparagus & 1 & Stewart Lake & 0.32 & 24 \\
\hline Catfish fillet & 3 & do. & 2.83 & 2.5 \\
\hline Carp fillet & 5 & do. & 5.3 & 1.3 \\
\hline Coot breast & 6 & do. & 2.7 & 2.6 \\
\hline Mallard breast & 3 & do. & 3.23 & 2.2 \\
\hline Shoveler breast & 4 & do. & .71 & 9.9 \\
\hline Canada goose breast & 1 & do. & .53 & 13.3 \\
\hline Northern pike fillet & 1 & $\operatorname{marsh} 4720$ & 8.2 & .9 \\
\hline Coot breast & 3 & Winter Storage Pond & 4.8 & 1.5 \\
\hline Whole crayfish & 2 & Ashley Creek & 9.9 & .7 \\
\hline Whole carp & 1 & do. & 21.9 & .3 \\
\hline Bluegill fillet & 4 & Pelican Lake & .47 & 15 \\
\hline Largemouth bass fillet & 2 & do. & .49 & 14.4 \\
\hline Cabbage & 1 & garden at Ouray NWR & $<.08$ & 100 \\
\hline Radishes & 1 & do. & $<.08$ & 100 \\
\hline Deer liver & 3 & Leota Bottom, Ouray NWR & .45 & 16 \\
\hline Canada goose & 1 & do. & .53 & 13.3 \\
\hline Coot breast & 6 & do. & .5 & 14.1 \\
\hline Gadwall breast & 3 & do. & 1.13 & 6.2 \\
\hline Redhead breast & 5 & do. & .45 & 15.7 \\
\hline Mallard breast & 1 & do. & .6 & 11.8 \\
\hline Mallard breast & 2 & Sheppard Bottom, Ouray NWH & $\begin{array}{ll}\mathrm{R} & 1.08\end{array}$ & 7 \\
\hline Coot breast & 4 & North Roadside Pond, Ouray I & NWR 5.34 & 1.3 \\
\hline Northern pike fillet & 1 & Green River near Ashley Cree & 1.37 & 5.2 \\
\hline Northern pike, whole & 2 & Green River near Ouray NWR & .4 & 17.2 \\
\hline
\end{tabular}

Selenium concentrations in 17 shallow wells in the Jensen area were variable and ranged from $<1$ to $360 \mu \mathrm{g} / \mathrm{L}$, but the larger concentrations generally occurred in wells located within areas for the J2, J3, and J4 drains. These drains also discharged the largest selenium concentrations to Stewart Lake, ranging from 27 to $92 \mu \mathrm{g} / \mathrm{L}$ during 1988-89. Median selenium concentrations in every drain exceeded the State of Utah standard of $5 \mu \mathrm{g} / \mathrm{L}$ established for wildlife protection. Stewart Lake acted as a sink for selenium discharged by the drains. Only 25 percent of the daily load of $252 \mathrm{~g}$ of selenium entering the lake was discharged to the Green River; the remainder was incorporated into sediment and plant tissue.

There was a statistically significant decline in specific conductance of water from drains J2 and J3 during the period from completion of the drains (1979-81) to 1989, but no significant trend in water 
from drains $\mathrm{J} 1$ and $\mathrm{J} 4$. On the basis of a generally positive relation between specific conductance and dissolved selenium, selenium concentrations appear to have declined in water from the J2 and J3 drains since 1979-81.

Stewart Lake supported a generally depauperate biota. Nesting success by waterbirds was poor, there were few insects, and selenium concentrations in tissue were large. Mean selenium concentrations in most whole-body fish exceeded the value of $12 \mu \mathrm{g} / \mathrm{g}$ associated with reproductive impairment. Stewart Lake was used extensively by great blue herons during the spring, and the large selenium concentrations present in the fish could be a hazard to the reproductive success of the herons. Selenium concentrations in non-emergent rooted aquatic plants and invertebrates were larger than the 4 to $8 \mu \mathrm{g} / \mathrm{g}$ level in foods associated with reduced reproductive success in mallards. Several deformed waterbirds (redhead and cinnamon teal) were found at Stewart Lake WMA.

Selenium concentrations in eggs from black-crowned night heron, gadwall, redhead, teal, western grebe, and common snipe at Stewart Lake WMA exceeded a $15 \mu \mathrm{g} / \mathrm{g}$ value reported to be associated with reproductive failure in some birds. One recently hatched juvenile American coot found dead had a whole-body selenium concentration of $86.9 \mu \mathrm{g} / \mathrm{g}$.

Selenium concentrations in Ashley Creek at 500 North Street in Vernal, upstream of the Vernal drains and the sewage lagoons, generally were less than $1 \mu \mathrm{g} / \mathrm{L}$. Concentrations in Ashley Creek at U.S. Highway 40 , about $12 \mathrm{mi}$ downstream, averaged $73 \mu \mathrm{g} / \mathrm{L}$ and $2 \mathrm{mi}$ farther downstream averaged $93 \mu \mathrm{g} / \mathrm{L}$. The source of the contamination was believed to be inflow of shallow ground water and surface water originating as seepage from a sewage-lagoon system. The seepage water dissolves evaporites and mobilizes selenium as it flows through Mancos Shale, and then discharges to Ashley Creek.

The largest selenium concentration $(16,000 \mu \mathrm{g} / \mathrm{L})$ found in any water sample during the 198689 study in the middle Green River basin occurred in seepage discharged directly to Ashley Creek at river mile 8.5 downgradient of the lagoon system. Drainwater discharged to Ashley Creek from 11 subsurface drains installed in the Vernal area by the USBOR had a mean selenium concentration of $4.5 \mu \mathrm{g} / \mathrm{L}$ and did not exceed $13 \mu \mathrm{g} / \mathrm{L}$ during the single sampling. Selenium concentrations in 70 percent of the tributaries that discharged to Ashley Creek between 500 North Street and U.S. Highway 40 exceeded the State standard of $5 \mu \mathrm{g} / \mathrm{L}$ established for wildlife protection.

Samples of biota from Ashley Creek had selenium concentrations that rank among the largest found in the middle Green River basin. The geometric mean selenium concentration in fish from Ashley Creek was $32.7 \mu \mathrm{g} / \mathrm{g}$ (dry weight). Selenium concentrations in potamogeton collected from the Winter Storage Pond in late fall and spring contained 16 and $30.4 \mu \mathrm{g} / \mathrm{g}$. Waterfowl collected during the fall to simulate hunter take had selenium concentrations ranging from 9.63 to $27.2 \mu \mathrm{g} / \mathrm{g}$ in muscle tissue. Selenium concentrations in waterbird eggs ranged from 7.3 to $60.6 \mu \mathrm{g} / \mathrm{g}$. A deformed teal embryo had a selenium concentration of $42.7 \mu \mathrm{g} / \mathrm{g}$. Although detailed studies were not completed for Ashley Creek, it is likely that adverse effects on waterbird nesting would be greater than those found at Stewart Lake WMA and similar to effects at the Roadside Ponds in Ouray NWR. In addition, populations of razorback suckers that may live in or near the confluence of Ashley Creek and the Green River may be adversely affected.

Large variations were found in selenium concentrations in monitoring wells in and near Ouray NWR. The median selenium concentration in 73 percent of the wells exceeded $30 \mu \mathrm{g} / \mathrm{L}$. Large selenium concentrations were found in wells in the NR3 well nest used to monitor shallow ground water entering the North Roadside Pond, with an average concentration of $133 \mu \mathrm{g} / \mathrm{L}$ for one well. The largest selenium concentrations measured in ground water at the Ouray NWR were in the S3 well in the southwest corner of the refuge near the Green River. Concentrations in this well increased from 3,200 $\mu \mathrm{g} / \mathrm{L}$ in November 1988 to $9,300 \mu \mathrm{g} / \mathrm{L}$ in June 1989 , and then declined slightly. It is unlikely that a significant volume of saline water containing large selenium concentrations was moving from the deep regional aquifer into the shallow aquifer that drains the alluvial soils; therefore, water in the wells was likely 
of local and shallow origin. Ground water not discharged in the area of the refuge likely flows to the Green River.

Although the water types (but not the large selenium concentrations) observed in the wells theoretically could be derived by evaporation of surface water, the hydrogen and oxygen isotopic composition of the water indicated evaporation was not the mechanism. The isotopic composition of the water, the distinctively different water type, and the variability of selenium concentrations in the wells suggest that ground water entering the western part of the refuge flows through geologic deposits considerably different from those found on the eastern part of the refuge.

Selenium concentrations in surface water at Ouray NWR were variable and depended on the source of water supplied to the ponds. Selenium concentrations in water from Pelican Lake that is supplied through the Ouray Park Canal never exceeded $1 \mu \mathrm{g} / \mathrm{L}$, whereas selenium concentrations in water from the North and South Roadside Ponds were generally large, with median concentrations near $40 \mu \mathrm{g} / \mathrm{L}$. The source of the selenium is shallow ground water entering as seepage into the North and South Roadside Ponds and ponds in Sheppard Bottom. Most of the recharge to the unconsolidated basin fill is to the shallow ground-water zone that may then discharge to ponds on the western boundary of the refuge.

Selenium concentrations in Sheppard S3 and S5 ponds did not exceed $4 \mu \mathrm{g} / \mathrm{L}$, but seepage entering S3 contained $73 \mu \mathrm{g} / \mathrm{L}$. The relatively large volumes of water from the Green River entering ponds in Sheppard Bottom diluted the large concentrations of selenium in water entering from seepage and from the South Roadside Pond. The quantity of seepage entering the North Roadside Pond was estimated to be 0.6 acre-ft per day.

There was a positive relation between selenium concentrations in pond sediment at Ouray NWR and concentrations of organic material in sediment. This association suggests a biological process may be involved in removal of selenium from the water and deposition in sediment.

Selenium concentrations in biota sampled at Pelican Lake, 2 mi west of Ouray NWR, were similar to those found at Leota Bottom, an area of the refuge regarded as uncontaminated. Selenium concentrations in American coot eggs from ponds in Sheppard Bottom were larger in birds from pond S5, closest to the Roadside Ponds. The most contaminated area found during this study was the Roadside Pond complex. The two ponds and adjacent area supported very little successful bird reproduction, and all biota contained very large selenium concentrations. Geometric mean selenium concentrations as large as $54.7 \mu \mathrm{g} / \mathrm{g}$ in eggs and $82.6 \mu \mathrm{g} / \mathrm{g}$ in fathead minnows were larger than concentrations known to adversely affect reproduction. Geometric mean concentrations in most plants (maximum $30.3 \mu \mathrm{g} / \mathrm{g}$ ) and invertebrates $(26.9 \mu \mathrm{g} / \mathrm{g}$ ) were larger than a reference concentration of 4 to $8 \mu \mathrm{g} / \mathrm{g}$ known to cause reproductive failure in mallards. Only a few samples of waterfowl eggs and one American coot egg from the Roadside Ponds had selenium concentrations in the eggs that were less than $15 \mu \mathrm{g} / \mathrm{g}$.

The rate of selenium uptake under field conditions was measured by releasing captive-reared mallards at the Roadside Ponds, systematically sacrificing them over time, and determining the selenium concentrations in their tissues. Mallards quickly accumulated selenium in liver and muscle tissue. Extreme weight loss occurred, and all birds died by the fourth week of exposure.

Ponds in Leota Bottom appeared to be representative of conditions expected in wetlands not contaminated by selenium. The Leota Bottom area does not receive agricultural return water or seepage from springs.

Water entering Pleasant Valley upstream of Pariette Wetlands met all Utah standards for agricultural and wildlife use. The boron concentration in the water was $370 \mu \mathrm{g} / \mathrm{L}$, and the selenium concentration was less than the reporting limit of $1 \mu \mathrm{g} / \mathrm{L}$. Within $3 \mathrm{mi}$ downstream of the site where water entered the valley, water in Pleasant Valley Wash contained a selenium concentration of $4 \mu \mathrm{g} / \mathrm{L}$. 
Water in the wash $5 \mathrm{mi}$ downstream contained a selenium concentration of $6 \mu \mathrm{g} / \mathrm{L}$ and a boron concentration of $1,100 \mu \mathrm{g} / \mathrm{L}$. The deterioration in water quality was believed to be a result of the discharge of poorer-quality tailwater and accrual of ground water into the wash. Water from four of five observation wells contained large to extremely large concentrations of evaporite salts, nitrate, and several metals. Water from one well $(\mathrm{OH} 148)$ contained concentrations of nitrite plus nitrate of 17 $\mathrm{mg} / \mathrm{L}$, boron of $29,000 \mu \mathrm{g} / \mathrm{L}$, selenium of $840 \mu \mathrm{g} / \mathrm{L}$, and dissolved solids of $42,000 \mathrm{mg} / \mathrm{L}$. Boron concentrations ranged from 500 to $2,400 \mu \mathrm{g} / \mathrm{L}$ and selenium from 1 to $11 \mu \mathrm{g} / \mathrm{L}$ in the other four wells.

Boron concentrations measured in water entering Pariette Wetlands 2.5 mi upstream of the desiltation pond and leaving the draw from Redhead Pond were consistently larger than the Utah agricultural standard of $750 \mu \mathrm{g} / \mathrm{L}$, with median concentrations of $1,200 \mu \mathrm{g} / \mathrm{L}$ or larger at both sites.

Selenium concentrations in ponds in Pariette Wetlands were variable, ranging from 1 to 7 $\mu \mathrm{g} / \mathrm{L}$. Water samples taken in Pariette Wetlands from 1987 to 1989 indicated concentrations of boron and selenium periodically exceeded applicable State water-quality standards. These levels could adversely affect waterfowl and fish.

Biota from Pariette Wetlands had selenium concentrations that were intermediate between reference levels at Leota Bottom (Ouray NWR) and concentrations from contaminated sites such as Stewart Lake. Twenty-nine percent of fish samples from Unit 1, and 8 percent from Unit 2 exceeded $12 \mu \mathrm{g} / \mathrm{g}$ selenium, a concentration suspected to be associated with reproductive failure. Reproductive problems were not evident in species of fish at Pariette Wetlands, but concentrations are larger than found at Pelican Lake and Leota Bottom.

Selenium concentrations in all eggs at all sites in Pariette Wetlands were less than $15 \mu \mathrm{g} / \mathrm{g}$ except for single pied-billed grebe eggs from Units 1 and 3. No deformed embryos were observed in eggs examined from sites in Pariette Wetlands. Eggs of several species exceeded the 8 to $10 \mu \mathrm{g} / \mathrm{g}$ level reported to be associated with reproductive impairment in other species. The bioaccumulation of selenium between water and aquatic plants or fish ranged from about 300 to 2,200 times the selenium concentration in water. Successive bioaccumulation factors within the biota ranged from 2 to 5 .

The abundance of evaporite minerals in the middle Green River basin results in the discharge of large quantities of dissolved solids and certain trace elements to the Green River, notably selenium and boron. Mean selenium concentrations in water increased from near the reporting level of $1 \mu \mathrm{g} / \mathrm{L}$ at Greendale to a mean of $2 \mu \mathrm{g} / \mathrm{L}$ at Green River, Utah. Large selenium concentrations were present in water discharged from Stewart Lake (mean $6.7 \mu \mathrm{g} / \mathrm{L}$ ) and Ashley Creek (mean $88 \mu \mathrm{g} / \mathrm{L}$ ). Ashley Creek contributed more than 16 percent of the selenium load to the Green River and 2 percent of the dissolved-solids load, but provided only 0.4 percent of the total flow at Green River, Utah. The Price River, which drains soils of Mancos Shale origin, contributed nearly one-half of the total selenium load present at Green River, Utah, in about 2 percent of the total flow.

Selenium concentrations in biota of the Green River received minimal study. Only common carp had selenium concentrations that exceeded a reference value of $12 \mu \mathrm{g} / \mathrm{g}$ associated with reduced reproductive success in some fish, and this sample was from a site adjacent to Stewart Lake WMA near the confluence of Ashley Creek. This site is known to be used regularly by Colorado squawfish and razorback suckers.

There was a close association between large selenium concentrations in water with soils of Billings clay in the Jensen area and along the east side of Ashley Creek. Selenium contamination of water at Ouray NWR was limited to a narrow strip of drainage near the west border and was not associated with any specific soil type.

Virtually all households in areas of the Uinta Basin where selenium contamination was documented in the 1986-87 reconnaissance study receive culinary water from public water supplies that are not contaminated with selenium. However, the large selenium concentrations found in fillets 
of carp and catfish and in breast tissue from coots from Stewart Lake WMA, prompted the Utah Department of Health to issue an advisory on September 26, 1988, for Stewart Lake, recommending consumption of no more than $10 \mathrm{oz}$ of fish or waterfowl per week for adult males. A similar advisory was issued August 22, 1991, for fish and waterfowl from Ashley Creek downstream of 500 North Street in Vernal and for the Winter Storage Pond. The large selenium concentrations found in wildlife in and near the Roadside Ponds and Sheppard Bottom in Ouray NWR, resulted in closure of the affected areas to public access for a short period in 1988, although hunting and fishing have never been allowed in these areas. 


\section{REFERENCES}

Beath, O.A., 1962, Selenium in a naturally occurring underground water: Science Newsletter, v. 81, p. 254.

Bellrose, F.C., 1976, Ducks, geese and swans of North America: Harrisburg, Pennsylvania, Stackpole Books, $544 \mathrm{p}$.

Berrow, M.L., and Ure, A.M., 1989, Geological materials and soils, in Milan and Ihnat, eds., Occurrence and distribution of selenium: Florida, CRC Press, p. 213-242.

Bloom, P.H., 1987, Capturing and handling raptors, in Giron, B.A., and others, eds., Raptor management techniques manual: Washington, D.C., National Wildlife Federation, p. 99-124.

Bodine, M.W., Jr., and Jones, B.F., 1986, The salt norm: a quantitative chemical-mineralogical characterization of natural waters: U.S. Geological Survey Water-Resources Investigations Report $86-4086,130 \mathrm{p}$.

Branson, R.L., 1976, Soluble salts, exchangeable sodium, and boron in soils, in Reisenauer, H.M., ed., Soil and plant-tissue testing in California: University of California, Division of Agricultural Sciences Bulletin 1879, p. 42-45.

Byers, H.G., 1936, Selenium occurrence in certain soils in the United States with a discussion of related topics, second report: U.S. Department of Agriculture Technical Bulletin 530, 78 p.

Byers, H.G., Miller J.T., Williams, K.T., and Lakin, H.W., 1938, Selenium occurrence in certain soils in the United States, with a discussion of related topics: U.S. Department of Agriculture Technical Bulletin 601, p. 1-74.

Caldwell, P.J., and Snart, A.E., 1974, A photographic index for aging mallard embryos: Journal of Wildlife Management, v. 38, no. 2, p. 298-301.

California State Water Resources Control Board, 1981, Interim guidance on possible wastewater discharges from the San Luis Drain: California State Water Resources Control Board, 16 p.

Callahan, M., Slimak, M., Gabel, N., May, I., Fowler, C., Freed, R., Jennings, P., Durfee, R., Whitmore, F., Maestri, B., Mabey, W., Holt, B., and Gould, C., 1979, Water-related fate of 129 priority pollutants, volume I: U.S. Environmental Protection Agency, report PB80-204373, 37 numbered sections.

Carrara, P.E., 1980, Surficial geologic map of the Vernal 1x2 degree quadrangle, Colorado and Utah: U.S. Geological Survey Miscellaneous Investigations Series Map I-1204, scale 1:250,000, 1 sheet.

Combs, G.F. Jr., and Combs, S.B., 1986, The role of selenium in nutrition: New York, Academic Press, 532 p.

Drever, J.I., 1982, The geochemistry of natural waters: New Jersey, Prentice-Hall, 388 p.

DuBowy, P.J., 1989, Effects of diet on selenium bioaccumulation in marsh birds: Journal of Wildlife Management, v. 53, no. 3, p. 776-781.

Eisler, Ronald, 1985, Selenium hazards to fish, wildlife, and invertebrates: a synoptic review: U.S. Fish and Wildlife Service, Contaminant Hazard Review Report No. 5, 57 p.

Epstein, S., and Mayeda, T., 1953, Variation of the O-18 content of waters from natural sources: Geochimica et Cosmochimica Acta, v. 4, p. 213-224.

Espinosa, L.R., and Clark, W.E., 1972, A polypropylene light trap for aquatic invertebrates: California Fish and Game Magazine, v. 58, no. 2, p. 149-152.

Fan, A.M., and Kizer, K.W., 1990, Selenium-nutritional, toxicologic, and clinical aspects: Western Journal of Medicine, v. 153, No. 2, p. 160-167. 
Feltis, R.D., 1966, Water from bedrock in the Colorado Plateau of Utah: Utah State Engineer Technical Publication No. 15, $82 \mathrm{p}$.

Fields, F.K., and Adams, D.B., 1975, Climatic and streamflow estimates for northeastern Utah: U.S. Geological Survey Open-File Report 75-673, 47 p.

Fishman, M.J., and Friedman, L.C., 1985, Methods for determination of inorganic substances in water and fluvial sediments: U.S. Geological Survey Techniques of Water-Resources Investigations, book 5, chap A1, 709 p.

Fujii, Roger, Deverel, S.J., and Hatfield, D.B., 1988, Distribution of selenium in soils of agricultural fields, western San Joaquin Valley, California: Soil Science Society of America Journal, v. 52, no. 5, p. 1274-1283.

Gat, J.R., 1980, The isotopes of hydrogen and oxygen in precipitation, in Fritz, P., and Fontes, J.C., eds., Handbook of environmental isotope geochemistry, v. 1: New York, Elsevier Scientific Publishing, p. 21-47.

Gilliom, R.J., 1989, Geologic source of selenium and its distribution in soil, in Gilliom, R.J., ed., Preliminary assessment of sources, distribution, and mobility of selenium in the San Joaquin Valley, California: U.S. Geological Survey Water-Resources Investigations Report 88-4186, p. 7-12.

Goode, H.D., and Feltis, R.D., 1962, Water production from oil wells of the Uinta Basin, Uintah and Duchesne Counties, Utah: Water Resources Bulletin 1, Utah Geological and Mineralogical Survey, $31 \mathrm{p}$.

Gough, L.P., Shacklette, H.T., and Case, A.A., 1979, Element concentrations toxic to plants, animals, and man: U.S. Geological Survey Bulletin 1466, 80 p.

Hanson, W.C., and Eberhardt, L.L., 1971, A Columbia River Canada goose population, 1950-1970: Wildlife Monograph Number 28, p. 1-61.

Heinz, G.H., 1979, Methylmercury: Reproductive and behavioral effects on three generations of mallard ducks: Journal of Wildlife Management, v. 43, p. 394-401.

Heinz, G.H., Hoffman, D.J., Krynitsky, A.J., and Weller, D.M.G., 1987, Reproduction in mallards fed selenium: Environmental Toxicology and Chemistry, v. 6, no. 6, p. 423-433.

Heinz, G.H., Hoffman, D.J., and Gold, L.G., 1988, Toxicity of organic and inorganic selenium to mallard ducklings: Archives for Environmental Contamination and Toxicology, v. 17, p. 561-568.

_- 1989, Impaired reproduction of mallards fed an organic form of selenium: Journal of Wildlife Management, v. 53, p. 418-428.

Heinz, G.H., Pendleton, G.W., Krynitsky, A.J., and Gold, L.G., 1990, Selenium accumulation and elimination in mallards: Archives for Environmental Contamination and Toxicology, v. 19, p. 374379.

Helsel, D.R., 1990, Less than obvious-statistical treatment of data below the detection limit: Environmental Science and Technology, v. 24, no. 12, p. 1766-1774.

Hendrickson, B.H., Jennings, D.S., Ewing, Scott, and Flanders, E.H., 1925, Soil survey of the Uinta River valley area, Utah: U.S. Department of Agriculture, Bureau of Soils, p. 1487-1528.

Higgs, D.J., Morris, V.C., and Levander, O.A., 1972, Effect of cooking on selenium content of foods: Journal of Agriculture and Food Chemistry, v. 20, p. 678-680.

Hirsch, R.M., Slack, J.R., and Smith, R.A., 1982, Techniques of trend analysis for monthly water quality data: Water Resources Research, v. 18, no. 1, p. 107-121. 
Hoffman, D.J., Camardese, M.B., Lecaptain, L.J., and Pendleton, G.W., 1990, Effects of boron on growth and physiology in mallard ducklings: Environmental Toxicology and Chemistry, v. 9, p. 335-346.

Holmes, W.F., and Kimball, B.A., 1987, Ground water in the southeastern Uinta Basin, Utah and Colorado: U.S. Geological Survey Water-Supply Paper 2248, 47 p.

Hood, J.W., 1976, Characteristics of aquifers in the northern Uinta Basin area, Utah and Colorado: Utah Department of Natural Resources Technical Publication No. 53, 71 p.

1977, Hydrologic evaluation of Ashley Valley, Northern Uinta Basin area, Utah: Utah Department of Natural Resources Technical Publication No. 54, 25 p.

Hood, J.W., and Fields, F.K., 1978, Water resources of the northern Uinta Basin area, Utah and Colorado, with special emphasis on ground-water supply: Utah Department of Natural Resources Technical Publication No. 62, 75 p.

Intermountain Association of Petroleum Geologists, 1964, Guidebook to the geology and mineral resources of the Unita Basin: Thirteenth annual field conference, Salt Lake City, Utah, Publisher Press, $276 \mathrm{p}$.

Intermountain Association of Geologists, 1969, Geologic guidebook of the Uinta Mountains: Sixteenth annual field conference, Salt Lake City, Utah, Publishers Press, 237 p.

Kendall, Carol, and Coplen, T.B., 1985, Multisample conversion of water to hydrogen by zinc for stable isotope determination: Analytical Chemistry, v. 57, p. 1427-1440.

King, P.B., and Beikman, H.M., 1974, Geologic map of the United States exclusive of Alaska and Hawaii: U.S. Geological Survey, scale 1:2,500,000.

Kirchner, K.H., 1991, A study of the groundwater flow and distribution of selenium within the groundwater system around Stewart Lake Waterfowl Management Area: Logan, Utah State University, Master's thesis, $75 \mathrm{p}$.

Klett, A.T., Duebbert, H.F., Faanes, C.A. and Higgins, K.F., 1986, Techniques for studying nest success of ducks in upland habitats in the prairie pothole region: U.S. Fish and Wildlife Service, Resource Publication 158, 24 p.

Laronne, J.B., 1977a, Dissolution potential of surficial Mancos Shale and alluvium: Ft. Collins, Colorado State University, unpublished Ph.D dissertation, $128 \mathrm{p}$.

1977b, Evaluation of the storage of diffuse sources of salinity in the Upper Colorado River Basin: Office of Water Research and Technology Completion Report B-121-COLO, U.S. Department of the Interior, $80 \mathrm{p}$.

Lemly, A.D., and Smith, G.J., 1987, Aquatic cycling of selenium: Implications for fish and wildlife: U.S. Fish and Wildlife Service, Fish and Wildlife Leaflet 12, $10 \mathrm{p}$.

Lohman, S.W., 1979, Ground-water hydraulics: U.S. Geological Survey Professional Paper 708, 70 p.

Lowe, T.P., May, T.W., Brumbaugh, W.G., and Kane, D.A., 1985, National contaminant biomonitoring program: Concentrations of seven elements in freshwater fish, 1978-1981: Archives of Environmental Contamination and Toxicology, v. 14, p. 363-388.

Marsell, R.A., 1964, Geomorphology of the Uinta Basin-A brief sketch, in Sabatka, E.F., ed., Guidebook to the geology and mineral resources of the Uinta Basin: Intermountain Association of Petroleum Geologists, Thirteenth annual field conference, p. 29-40.

Masscheleyn, P.H., Delaune, R.D., and Patrick, W.H., Jr., 1990, Transformations of selenium as affected by sediment oxidation reduction potential and pH: Environmental Science and Technology, v. 24, no. 1, p. 91-96. 
Mitchum, D.L., and Moore, T.D., 1966, Study of water pollution problems which affect fish and other aquatic forms: Laramie, University of Wyoming, Game and Fish Laboratory Report FW-3-R-13, 32 p.

Morris, D.A., and Johnson, A.I., 1967, Summary of hydrologic and physical properties of rock and soil materials, as analyzed by the hydrologic laboratory of the U.S. Geological Survey, 1948-60: U.S. Geological Survey Water-Supply Paper 1839-D, 42 p.

National Academy of Sciences, 1980, Recommended dietary allowances, ninth edition: Washington, D.C., $185 \mathrm{p}$.

1983, Drinking water and health, v. 5: Washington, D.C., National Academy of Sciences Press, $157 \mathrm{p}$.

National Research Council, 1989, Irrigation-induced water quality problems: Committee on IrrigationInduced Water Quality Problems, National Academy Press, Washington, D.C., 157 p.

National Oceanic and Atmospheric Administration, 1982, Monthly normals of temperature, precipitation, and heating and cooling degree days 1951-80: Climatography of the United States No. 81 (Utah), National Climatic Center, Asheville, N.C., 42 p.

Neal, R.H., and Sposito, Garrison, 1989, Selenate adsorption on alluvial soils: Journal of the Soil Science Society of America, v. 53, p. 70-74.

Oremland, R.S., Hollibaugh, J.T., Maest, A.S., Presser, T.S. Miller, L.G. and Culbertson, C.W., 1989, Selenate reduction to elemental selenium by anaerobic bacteria in sediments and culture: Biogeochemical significance of a novel, sulfate-independent respiration: Applied and Environmental Microbiology, v. 55, p. 2333-2343.

Parkhurst, D.L., Plummer, L.N., and Thorstenson, D.C., 1982, Balance-A computer program for calculating mass transfer for geochemical reactions in ground water: U.S. Geological Survey, Water-Resources Investigations Report 82-14, 29 p.

Pattee, O.H., Bloom, P.H., Scott, J.M., and Smith, M.R., 1990, Lead hazards within the range of the California Condor: The Condor, v. 92, p. 931-937.

Peltz, L.A., and Waddell, Bruce, 1991, Physical, chemical and biological data for detailed study of irrigation drainage in the middle Green River basin, Utah, 1988-89, with selected data for 1982-87: U.S. Geological Survey Open-File Report 91-530, 213 p.

Presser, T.S., and Ohlendorf, H.M., 1987, Biogeochemical cycling of selenium in the San Joaquin Valley, California, USA: Environmental Management, v. 11, no. 6, p. 805-821.

Price, Don, and Miller, L.L., 1975, Hydrologic reconnaissance of the southern Uinta Basin, Utah and Colorado: Utah Department of Natural Resources Technical Publication No. 49, 66 p.

Rosenfeld, Irene, and Beath, O.A., 1964, Selenium-geobotany, biochemistry, toxicity, and nutrition: New York, Academic Press, 411 p.

Rowley, P.D., Hansen, W.R., Tweto, Ogden, and Carrara, P.E., 1985, Geologic map of the Vernal 1x2 degree quadrangle, Colorado, Utah, and Wyoming: U.S. Geological Survey Miscellaneous Investigations Series Map I-1526, scale 1:250,000, 1 sheet.

Schmitt, C.J., and Brumbaugh, W.G., 1990, National contaminant biomonitoring program: concentrations of arsenic, cadmium, copper, lead, mercury, selenium, and zinc in U.S. freshwater fish, 1976-1984: Archives of Environmental Contamination and Toxicology, v. 19, p. 731-747.

Schuler, Carol, 1989, Selenium and boron accumulation in wetlands and waterfowl food at Kesterson Reservoir, in Howard, A.Q., ed., Selenium and agricultural drainage: Implications for San Francisco Bay and the California environment, Proceedings of the fourth selenium symposium: Sausalito, Bay Institute of San Francisco, p. 91-101. 
Severson, R.C., Wilson, S.A., and McNeal, J.M., 1987, Analyses of bottom material collected at nine areas in the western United States for the DOI irrigation drainage task group: U.S. Geological Survey OpenFile Report 87-490, 24 p.

Skorupa, J.P., and Ohlandorf, H.M., 1991, Contaminants in drainage water and avian risk thresholds, in Dinar, A. and Zilberman, D., eds., The economics and management of water and drainage in agriculture: Norwell, Mass., Kluwer Academic Publishing, p. 345-368.

Smith, G.J., and Anders, V.P., 1989, Toxic effects of boron on mallard reproduction: Environmental Toxicology and Chemistry, v. 8, p. 943-950.

Stephens, D.W., and Waddell, Bruce, 1989, Selenium contamination from irrigation drainage in the western United States with emphasis on Utah, in Cordy, G.E., ed., Geology and hydrology of hazardouswaste, mining-waste, waste-water, and repository sites in Utah: Utah Geological Association Publication 17, p. 165-181.

Stephens, D.W., Waddell, Bruce, and Miller, J.B., 1988a, Reconnaissance investigation of water quality, bottom sediment, and biota associated with irrigation drainage in the middle Green River basin, Utah, 1986-87: U.S. Geological Survey Water-Resources Investigations Report 88-4011, 70 p.

1988b, Irrigation drainage: Green River basin, Utah: American Society of Civil Engineers, Proceedings of the 1988 National Irrigation and Drainage Conference, Lincoln, Nebraska, p. 686693.

Stokes, W. L., 1986, Geology of Utah: Utah Museum of Natural History, 280 p.

Strahorn, A.T., Ewing, Scott, and Jennings, D.S., 1924, Soil survey of the Ashley Valley, Utah: U.S. Department of Agriculture, Bureau of Soils, Washington, D.C., Government Printing Office, 29 p.

Thatcher, L.L., Janzer, V.J., and Edwards, K.W., 1977, Methods for determination of radioactive substances in water and fluvial sediments: U.S. Geological Survey Techniques of Water-Resources Investigations, book 5, chap. A5, $95 \mathrm{p}$.

Tidball, R.R., and Seversen, R.C., 1982, Study no. 12, Alluvial soils of the Piceance Creek and Uinta Basins, in Ebens, R.J., and Shacklette, H.T., eds., Geochemistry of some rocks, mine spoils, stream sediments, soils, plants, and waters of the western energy region of the conterminous United States: U.S. Geological Survey Professional Paper 1237, 173 p.

Tidball, R.R., Severson, R.C., Gent, C.A., and Riddle, G.O., 1986, Element associations in soils of the San Joaquin Valley, California: U.S. Geological Survey Open-File Report 86-583, 15 p.

Trelease, S.F., and Beath, O.A., 1949, Selenium, its geological occurrence and its biological effects in relation to botany, chemistry, agriculture, nutrition, and medicine: published by the authors, Burlington, Vermont, Champlain Printers, 292 p.

Untermann, G.E., and Untermann, B.R., 1954, Geology of Dinosaur National Monument and vicinity, UtahColorado: Utah Geological and Mineralogical Survey Bulletin 42, 228 p.

U.S. Bureau of Reclamation, 1977, Prediction of mineral quality of irrigation return flow-volume II, Vernal field study: Environmental Protection Agency Report 600-2-77-179b, 105 p.

U.S. Department of Agriculture, 1977, Vegetative types and land-resource areas--Utah: Soil conservation Service, scale 1:1,500,000.

U.S. Geological Survey, 1977, National handbook of recommended methods for water-data acquisition: Reston, Virginia, 12 numbered sections.

Utah Department of Health, 1988, Wastewater disposal regulations-Part II, standards of quality for waters of the State: Utah Department of Health, Division of Environmental Health, $50 \mathrm{p}$. 
Utah Geological Association, 1985, Geology and energy resources, Uinta Basin of Utah: Utah Geological Association Guidebook 12, Salt Lake City, Utah, 338 p.

Waddell, K.M., Sumsion, C.T., Butler, J.R., and Contratto, P.K., 1981, Hydrologic reconnaissance of the Wasatch Plateau-Book Cliffs coal-fields area: U.S. Geological Survey Water-Supply Paper 2068, 45 p.

Wenzel, L.K., and Fischel, V.C., 1942, Methods of determining permeability of water-bearing materials with special reference to discharging-well methods: U.S. Geological Survey Water-Supply Paper 887, 192 p.

Westerkov, K.V., 1950, Methods for determining the age of game-bird eggs: Journal of Wildlife Management, v. 14, p. 56-67.

Wiemeyer, S.N., Frenzel, R.W., Anthony, R.G., McClelland, B.R., and Knight, R.L., 1989, Environmental contaminants in blood of western bald eagles: Journal of Raptor Research, v. 23, no. 4, p. 140-146.

Williams, K.T., and Byers, H.G., 1935, Occurrence of selenium in the Colorado River and some of its tributaries: Industrial and Engineering Chemistry, v. 7, no. 6, p. 431-432.

Wilson, L.M., Jennings, D.S., Jensen, Duane, Peterson, J.D., Foulger, Clark, and Woodward, H.K., 1959, Soil survey of Roosevelt-Duchesne area, Utah: U.S. Department of Agriculture, Soil Conservation Service, Soil Survey series 1940, no. 24, 61 p. 